UNIVERSIDADE DE SÃO PAULO

FACULDADE DE ECONOMIA, ADMINISTRAÇÃO E CONTABILIDADE DEPARTAMENTO DE ADMINISTRAÇÃO

PROGRAMA DE PÓS-GRADUAÇÃO EM ADMINISTRAÇÃO

ESTRATÉGIAS DE SEGMENTAÇÃO E POSICIONAMENTO DIRECIONADAS PARA O MERCADO INFANTIL

Andres Rodriguez Veloso

Orientador: Prof. Dr. Marcos Cortez Campomar

São Paulo

2008 
Profa. Dra. Suely Vilela

Reitora da Universidade de São Paulo

Prof. Dr. Carlos Roberto Azzoni

Diretora da Faculdade de Economia, Administração e Contabilidade

Prof. Dr. Izak Kuglianskas

Chefe do Departamento de Administração

Prof. Dr. Lindolfo Galvão de Albuquerque

Coordenador do Programa de Pós-Graduação em Administração 


\title{
ESTRATÉGIAS DE SEGMENTAÇÃO E POSICIONAMENTO DIRECIONADAS PARA O MERCADO INFANTIL
}

\author{
Tese de Doutorado \\ apresentado ao Departamento \\ de Administração da \\ Faculdade de Economia, \\ Administração \\ e \\ Contabilidade \\ da \\ Universidade de São Paulo \\ como requisito para a \\ obtenção do título de Doutor \\ em Administração.
}

Orientador: Prof. Dr. Marcos Cortez Campomar 


\section{FICHA CATALOGRÁFICA}

\section{Elaborada pela Seção de Processamento Técnico do SBD/FEA/USP}

\section{Veloso, Andres Rodriguez}

Estratégias de segmentação e posicionamento direcionadas para o mercado infantil / Andres Rodriguez Veloso. -- São Paulo, 2008. $300 \mathrm{p}$.

Tese (Doutorado) - Universidade de São Paulo, 2008 Bibliografia.

1. Segmentação de mercado 2.Crianças 3. Estudo de caso 4. Marketing estratégico I. Universidade de São Paulo. Faculdade de Economia, Administração e Contabilidade II. Título.

CDD - 658.802 
Dedico este trabalho aos meus pais, José Miguel e Maria Antonieta. 
Gostaria de agradecer aos professores da Faculdade de Economia, Administração e Contabilidade da Universidade de São Paulo pela excelente oportunidade acadêmica que me foi oferecida, tanto durante meu curso de graduação como no doutorado.

Agradeço especialmente ao Professor Doutor Marcos Cortez Campomar, que foi fundamental na orientação necessária para a realização deste trabalho. Além da orientação acadêmica o Prof. Dr. Marcos Cortez Campomar também teve papel importantíssimo na minha formação profissional, por meio dos seus ensinamentos que tratavam não somente de marketing, mas também da postura que um profissional da área deve ter.

Cabe agradecer também aos Professores Doutores Ana Akemi Ikeda, Edson Crescitelli e Geraldo Toledo, que presenciaram o desenvolvimento deste trabalho e que em sala de aula me ensinaram importantes lições sobre a área de marketing.

Agradeço de forma calorosa aos amigos que estiveram ao meu lado durante a jornada que constitui a realização de uma tese, especialmente Alexandre Mattar, Fábio Moraes da Costa, Guilherme de Farias Shiraishi, Marcelo Praxedes da Silva, Patrícia Regina Caldeira Daré e Lucas Fajardo Nunes Hildebrand. Um agradecimento especial para Diogo Fajardo Nunes Hildebrand, que teve a paciência de acompanhar este trabalho desde seu início, dando sugestões, revisando o texto e me incentivando no sentido de completar esta tarefa.

Agradeço também aos profissionais de marketing que foram solícitos em participar da coleta de dados oferecendo informações valiosas sobre as suas empresas - Tadeu Ribeiro, Gustavo Arruda , Massao Takehara e Marta Giardani.

Por último deixo meu agradecimento para a pessoa que esteve ao meu lado durante a elaboração deste trabalho e que deu um apoio fundamental na realização da coleta de dados indispensável para a conclusão deste trabalho - Beatriz Camargo de Moraes. 
No segmento de brinquedo é assim. Um dia da ilusão. Muito gostoso. Tadeu Ribeiro - Gerente de Vendas da Pica Pau Brinquedos 


\section{RESUMO}

Este trabalho teve como objetivo principal identificar as estratégias de segmentação e posicionamento que são apresentadas na literatura de marketing e verificar se as empresas focadas no mercado infantil seguem as sugestões da literatura. Para atingir esse objetivo algumas etapas foram transpostas. Primeiramente foi conduzida uma revisão teórica buscando responder ao problema de pesquisa colocado. A revisão teórica focou nos conceitos de segmentação de mercado, posicionamento e consumo infantil. Esse primeiro esforço de pesquisa não teve sucesso, indicando a necessidade de se realizar um estudo de campo para aprofundar o conhecimento sobre o fenômeno estudado. Como método de pesquisa determinou-se que o método de estudo de caso seria o mais adequado para o foco do trabalho. Foram entrevistadas três empresas do setor de brinquedos, visando identificar as estratégias de segmentação e posicionamento adotadas - Grow Brinquedos, Brinquedos Pica Pau e Mitra Officina de Criação. Os casos foram analisados de forma individual e cruzada, buscando-se o aprofundamento das análises. De forma resumida é possível dizer que as empresas não conduzem esforços estruturados de segmentação, preferindo tomar decisões com base na tradição da empresa, além disso, os esforços de posicionamento são bastante restritos, sendo decididos pela experiência prática dos executivos e pela observação de mercados internacionais. Esses resultados indicam a existência de um grande potencial competitivo que pode ser alcançado caso essas empresas passem para um nível superior do uso das ferramentas de marketing.

Palavras-chave: segmentação de mercado; crianças; estudo de caso; marketing estratégico. 


\begin{abstract}
This work had as primary objective to identify the segmentation and positioning strategies of companies focused on the kids market and to verify if these companies follow the recommendations of the literature. To attain this objective some stages needed to be transposed. First of all a literature review was conducted, aiming to respond the research question proposed. This review focused on the segmentation, positioning and kids market. This first effort was not successful, indicating the necessity of conducting a field study to deepen the understanding of the studied phenomenon. As research method the case study method was determined as the most adequate to the focus of this word. Three organization of the toy market were interviewed, aiming to identify the strategies of segmentation and positioning adopted - Grow Brinquedos, Brinquedos Pica Pau e Mitra Officina de Criação. The cases were first individually analyzed, afterwards a cross-case analysis was conducted. In a resumed form is possible to say that none of the companies conduct structured processes of segmentation and positioning, preferring to make strategic decisions taking as base the companies tradition, besides that, the positioning efforts are very restrict, being decided by the practical experience of the executives and by observation of international marketing. These results indicate the existence of a great competitive potential that can be reached by these companies taking a step ahead in using the marketing tools.
\end{abstract}

Key-Words: market segmentation; children; case study; strategic marketing. 


\section{SUMÁRIO}

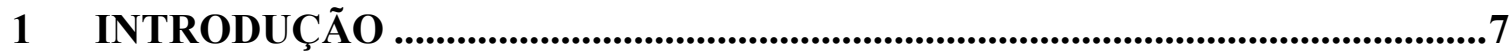

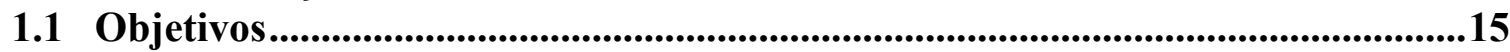

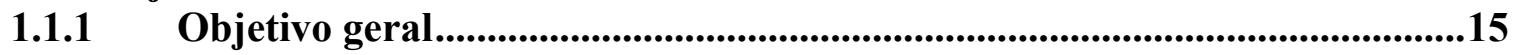

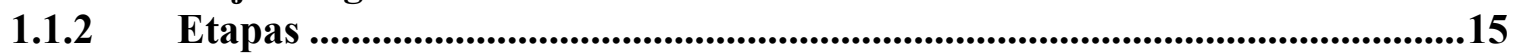

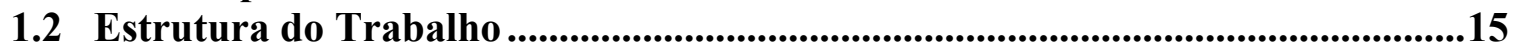

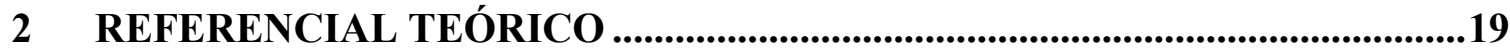

2.1 Importância do mercado infantil .......................................................................19

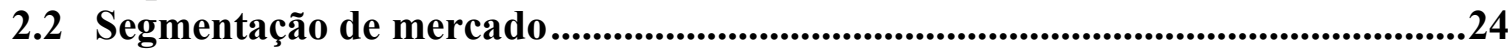

2.2.1 Conceito de segmentação de mercado ................................................................24

2.2.2 O processo de segmentação de mercado ..............................................................31

2.2.3 Bases de segmentação de mercado ..........................................................35

2.2.4 Modelos de segmentação proprietários .........................................................41

2.2.5 Efetividade do processo de segmentação de mercado ......................................43

2.3 Segmentação e o mercado infantil...............................................................................50

2.3.1 Variáveis de segmentação - idade...............................................................50

2.3.2 Variáveis de segmentação - idade - desenvolvimento cognitivo...................53

2.3.3 Variáveis de segmentação - idade - processo de socialização........................59

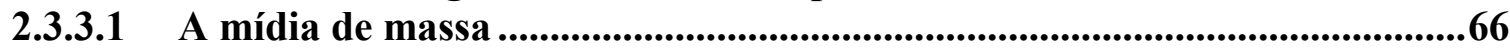

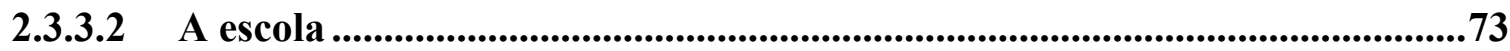

2.3.3.3 Os pais............................................................................................................................77

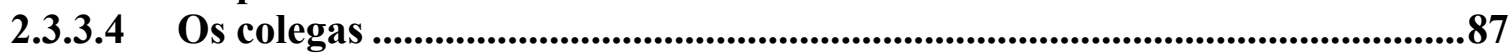

2.3.4 Variáveis de segmentação - nível de desenvolvimento da criança...............91

2.3.5 Pesquisa de segmentação e o consumidor infantil ..........................................95

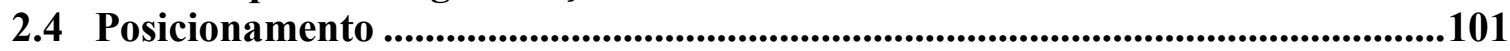

2.4.1 Origem do conceito de posicionamento .................................................................102

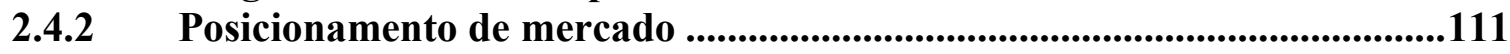

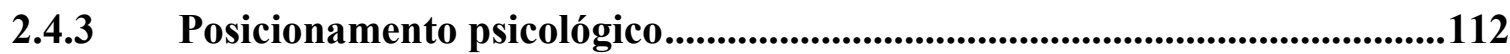

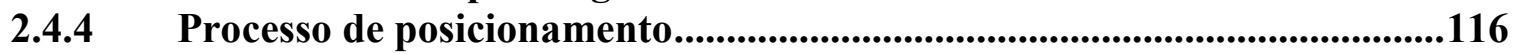

2.4.5 Modelo do processo de posicionamento estratégico ..................................120

2.4.6 Efetividade do posicionamento............................................................................122

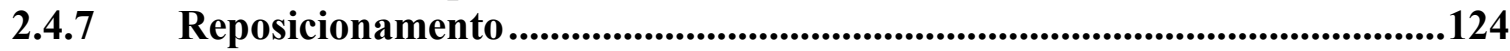

2.5 Posicionamento no mercado infantil...........................................................127

2.5.1 Desenvolvimento de novos produtos .....................................................127

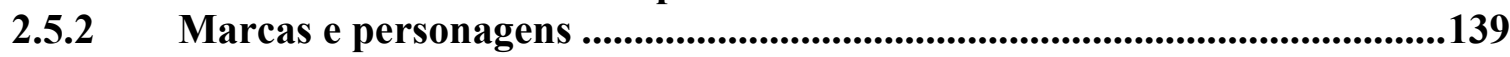

2.5.3 Questões relativas à precificação e o consumidor infantil ..........................146

2.5.4 $O$ ponto de venda e o consumidor infantil.............................................152

2.5.5 Estratégias de comunicação com o consumidor infantil .............................156

3 MÉTODOLOGIA DA PESQUISA DE CAMPO ..........................................170

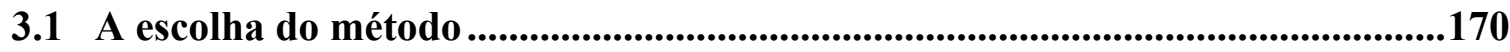

3.2 O processo de amostragem na pesquisa qualitativa .............................................174

3.2.1 Escolha do setor e das empresas pesquisadas ............................................175

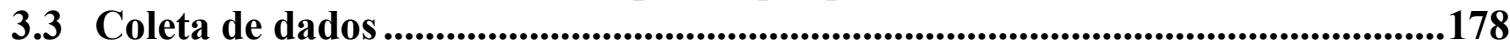

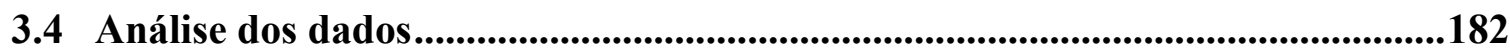

4 RESULTADOS DA PESQUISA DE CAMPO..............................................187

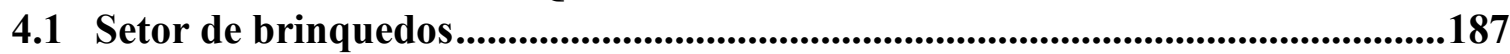

4.2 Caso 1 - Brinquedos Pica Pau ...........................................................................190

4.2.1 Estratégia de segmentação...........................................................................................190

4.2.2 Estratégia de posicionamento ....................................................................................194 
4.2.2.1 Estratégia de posicionamento de mercado ...............................................194

4.2.2.2 Estratégia de posicionamento psicológico ..........................................................198

4.2.2.2.1. Estratégia de posicionamento psicológico - produto ..............................198

4.2.2.2.2. Estratégia de posicionamento psicológico - preço ..................................204

4.2.2.2.3. Estratégia de posicionamento psicológico - praça ...................................205

4.2.2.2.4. Estratégia de posicionamento psicológico - promoção .............................207

4.2.3 Resumo da análise da Pica Pau Brinquedos ..............................................209

4.3 Caso 2 - Grow Jogos e Brinquedos LTDA ...................................................211

4.3.1 Estratégia de segmentação.........................................................................212

4.3.2 Estratégia de posicionamento ...........................................................................216

4.3.2.1 Estratégia de posicionamento de mercado .................................................216

4.3.2.2 Estratégia de posicionamento psicológico ........................................................219

4.3.2.2.1. Estratégia de posicionamento psicológico - produto ..............................219

4.3.2.2.2. Estratégia de posicionamento psicológico - preço ...................................223

4.3.2.2.3. Estratégia de posicionamento psicológico - praça ....................................224

4.3.2.2.4. Estratégia de posicionamento psicológico - promoção ..........................225

4.3.3 Resumo da análise da Grow Jogos e Brinquedos Ltda .............................230

4.4 Caso 3 - Mitra Officina de Criação .............................................................232

4.4.1 Estratégia de segmentação...............................................................................233

4.4.2 Estratégia de posicionamento ..................................................................236

4.4.2.1 Estratégia de posicionamento de mercado .................................................237

4.4.2.2 Estratégia de posicionamento psicológico ..................................................240

4.4.2.2.1. Estratégia de posicionamento psicológico - produto .................................240

4.4.2.2.2. Estratégia de Posicionamento Psicológico - preço ..................................242

4.4.2.2.3. Estratégia de Posicionamento Psicológico - praça...................................244

4.4.2.2.4. Estratégia de posicionamento psicológico - promoção/comunicação...245

4.4.3 Resumo da análise da Mitra Officina de Criação.........................................247

4.5 Análise cruzada dos casos e a teoria .................................................................249

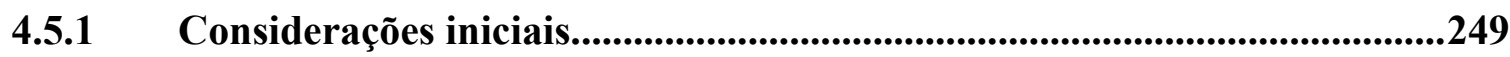

4.5.2 Estratégia de segmentação.................................................................250

4.5.3 Posicionamento de mercado ..................................................................253

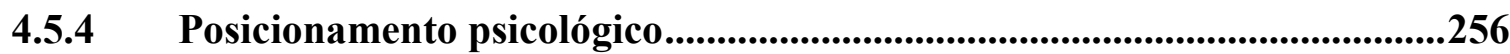

4.5.4.1 Posicionamento psicológico - produto..................................................................256

4.5.4.2 Posicionamento psicológico - preço ......................................................259

4.5.4.3 Posicionamento psicológico - praça.........................................................262

4.5.4.4 Posicionamento psicológico - promoção/comunicação ...............................264

4.5.5 Posicionamento psicológico - considerações gerais .....................................267

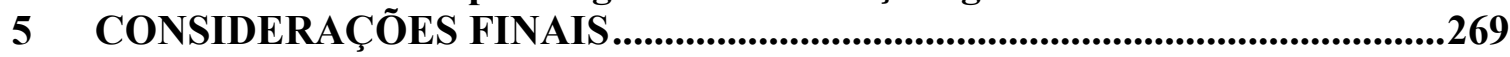

5.1 Limitações do trabalho...........................................................................................274

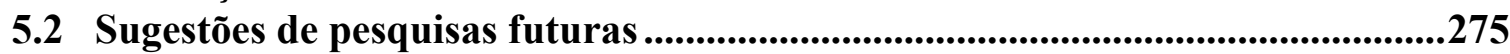

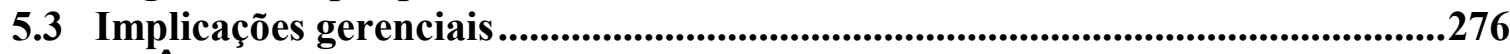

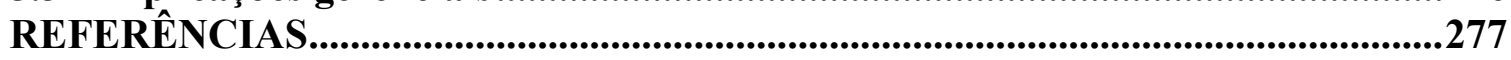




\section{LISTA DE QUADROS}

Quadro 1 - Fatores que explicam o crescimento da importância do consumidor infantil........ 23

Quadro 2 - Critérios de segmentação de mercado..................................................................... 37

Quadro 3 - O Processo de Segmentação .............................................................................. 39

Quadro 4 - Barreiras ao processo de segmentação de mercado .............................................. 49

Quadro 5. Os quatro estágios do desenvolvimento cognitivo segundo Piaget.........................54

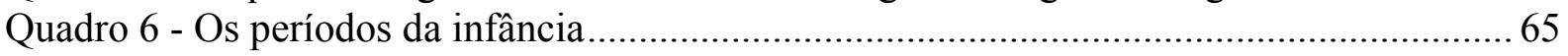

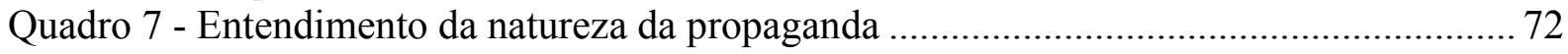

Quadro 8 - Indicadores do desenvolvimento da criança como consumidora no contexto do

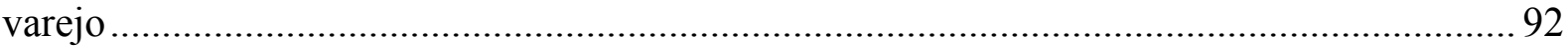

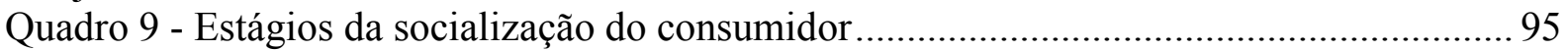

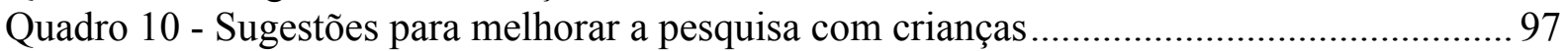

Quadro 11 - Métodos de pesquisa e o consumidor infantil ................................................... 98

Quadro 12 - As seis mais importantes necessidades das crianças....................................... 131

Quadro 13 - Valores chave que direcionam o sucesso do marketing para crianças............... 134

Quadro 14 - O desenvolvimento da criança e os produtos mais apropriados ........................ 135

Quadro 15 - Motivadores Centrais dos Pré-adolescentes..................................................... 137

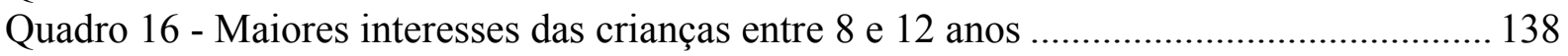

Quadro 17 - Centros de interesse da criança ....................................................................... 138

Quadro 18 - O desenvolvimento das capacidades cognitivas da criança e seu entendimento das

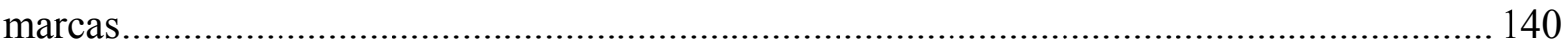

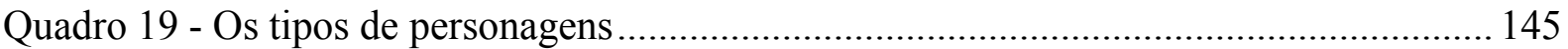

Quadro 20 - Lojas favoritas das crianças ........................................................................ 154

Quadro 21 - Marketing para os sucessivos segmentos de idade por meio de várias mídias .. 158

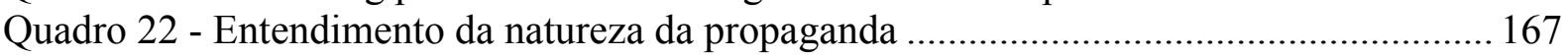

Quadro 23 - Situações relevantes para diferentes estratégias de pesquisa ............................ 172

Quadro 24 - Ligando a questão de pesquisa com a estratégia............................................... 173

Quadro 25 - Seis fontes de evidência: pontos fortes e pontos fracos ................................... 180

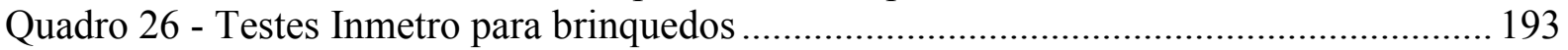

Quadro 27 - Comparação teoria e prática - Segmentação ...................................................... 251

Quadro 28 - Comparação teoria e prática - posicionamento de mercado................................2254

Quadro 29 - Comparação teoria e prática - posicionamento psicológico - produto ................257

Quadro 30 - Comparação teoria e prática - posicionamento psicológico - preço................... 260

Quadro 31 - Comparação teoria e prática - posicionamento psicológico - praça ....................263

Quadro 32 - Comparação teoria e prática - posicionamento psicológico - promoção ........... 266 
LISTA DE TABELAS

Tabela 1 - Opinião dos pais sobre as diversas fontes de influências sobre o comportamento das crianças .66

Tabela 2 - Disponibilidade dos diversos tipos de mídia no quarto das crianças norte americanas

Tabela 3 - Renda, gastos e economias médias semanais de crianças, de acordo com a idade, em 1984 e 1989

Tabela 4 - Tipos de varejistas classificados como orientados para a criança - 1984 versus 1991

Tabela 5 - Disponibilidade dos diversos tipos de mídia no quarto das crianças norte americanas

Tabela 6 - Faturamento do Setor de Brinquedos (R \$ Milhões)

Tabela 7 - Número de Funcionários da Indústria Nacional

Tabela 8 - Lançamento de Novos Brinquedos

Tabela 9 - Segmentação das Vendas por Grupos 


\section{LISTA DE ILUSTRAÇÕES}

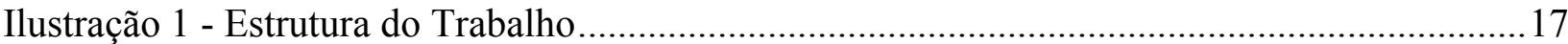

Ilustração 2 - Desenvolvimento do segmento infantil nos Estados Unidos (1950-1980) ..............21

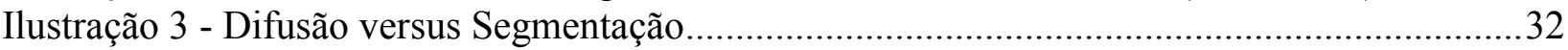

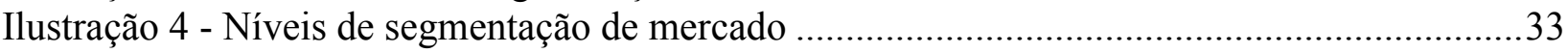

Ilustração 5 - Processo de macro e micro-segmentação...............................................................40

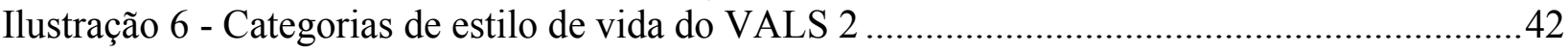

Ilustração 7 - O papel dos fatores de sucesso da segmentação ...................................................45

Ilustração 8 - Modelo de Porter para análise do mercado. ..........................................................46

Ilustração 9 - Desenvolvimento das competências como consumidor durante a infância .............51

Ilustração 10 - Influências ambientais no desenvolvimento da criança .......................................58

Ilustração 11 - Processo de socialização de Moschis e Churchill ..................................................63

Ilustração 12 - Esquema do Processo de Marketing ..................................................................110

Ilustração 13 - As Associações de Marca........................................................................................ 114

Ilustração 14 - Modelo do processo de posicionamento de Toledo e Hemzo...............................118

Ilustração 15 - Processo de Posicionamento Estratégico ............................................................121

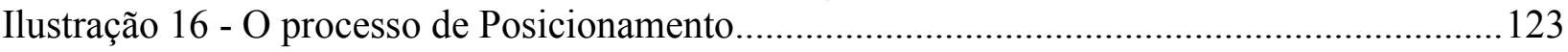

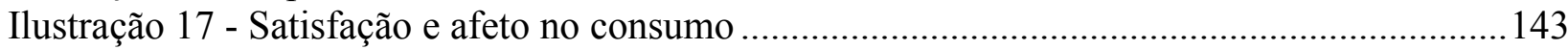

Ilustração 18 - Ri-Rappy: Original Vs Desenhos.......................................................................144

Ilustração 19 - Renda, economias e gastos médios semanais das crianças super-privilegiadas

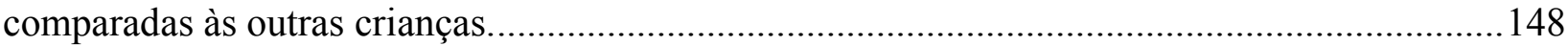

Ilustração 20 - O que faz uma loja ser a favorita das crianças? ...............................................155

Ilustração 21 - Propagandas mal feitas produzem maus resultados para os profissionais da

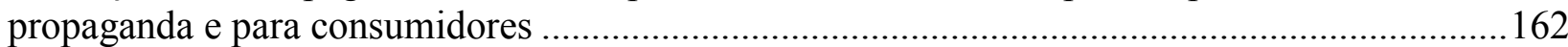

Ilustração 22 - Logotipo comemorativo - Brinquedos Pica Pau.................................................. 190

Ilustração 23 - Brinquedos Pica Pau - Orgulho ........................................................................ 190

Ilustração 24 - Brinquedos para crianças até 2 anos ................................................................ 191

Ilustração 25 - Adaptações de personagens famosos ................................................................201

Ilustração 26 - Processo de segmentação e posicionamento da Pica Pau ...................................210

Ilustração 27 - Logotipo da empresa Grow Jogos e Brinquedos Ltda. .......................................211

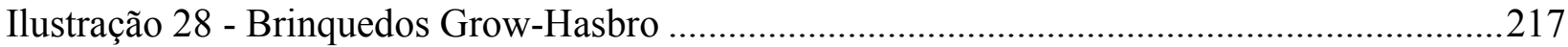

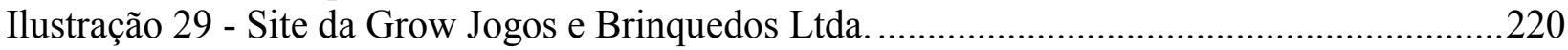

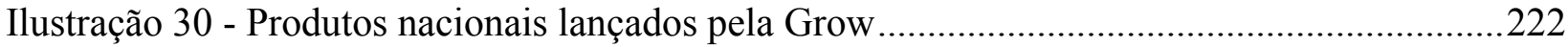

Ilustração 31 - Site de jogos eletrônicos...............................................................................227

Ilustração 32 - Processo de segmentação e posicionamento da Grow Jogos e Brinquedos Ltda 231

Ilustração 33 - Logotipo da empresa Mitra Officina de Criação................................................232

Ilustração 34 - Enciclopédia de Jogos ...............................................................................232

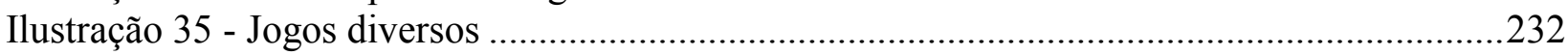

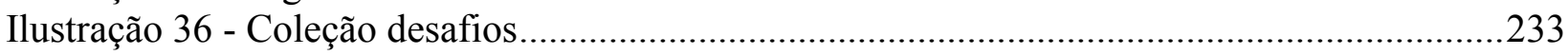

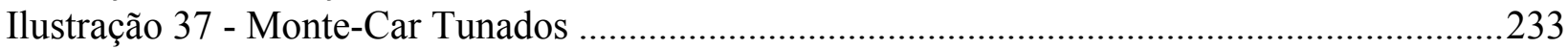

Ilustração 38 - Composição do Monte-Car Tunados ................................................................241

Ilustração 39 - Site da empresa Mitra Officina de Criação ........................................................246

Ilustração 40 - Processo de segmentação e posicionamento da Mitra Officina de Criação.........248 


\section{INTRODUÇÃO}

O segmento de mercado composto por crianças com idade entre 0 e 12 anos, doravante denominado mercado infantil ou segmento infantil, constitui um público de cerca de 44 milhões de crianças ou $25,5 \%$ da população brasileira, conforme o censo realizado em 2000 pelo IBGE - Instituto Brasileiro de Geografia e Estatística (2006). Desse total, 50,8\% são do sexo masculino e 49,2\% do sexo feminino. Dos 44 milhões de crianças, cerca de 34 milhões moram na zona urbana e cerca de 10 milhões na zona rural.

Ainda, na visão de McNeal (1992), a criança pode assumir diversos papéis como consumidora: mercado primário (a criança pode ser um consumidor); mercado influenciador (a criança pode influenciar o consumo de produtos); e mercado futuro (a criança constitui um mercado potencial).

Contudo, nem sempre a criança teve a importância que tem atualmente dentro da sociedade. "As sociedades ocidentais dedicam hoje uma importância cada vez maior para à criança" (MONTIGNEAUX, 2003, p.15). Essa visão, que considera a criança como algo sagrado, sem preço e insubstituível, é oriunda do século XX (SCHOR, 2004), portanto, é de se esperar que estudos que foquem nas peculiaridades do comportamento de consumo da criança estarão estudando fenômenos relativamente inexplorados.

Dados da Abrinq - Associação Brasileira de Fabricantes de Brinquedos - (2006) mostram um setor que em 2005 movimentou cerca de 900 milhões de reais, representando um crescimento de 5,9\% em relação ao ano anterior. A importância desse segmento é reafirmada pelo interesse de publicações não acadêmicas no tema, como por exemplo, a revista semanal Veja, os jornais Folha de São Paulo e Estado de São Paulo e a revista especializada no varejo SuperHiper (BANNON, 1998; FERNANDES, 1997; GRANATO, 1998 e PIRES, 1995). As empresas também não deixaram de perceber a importância desse grupo de consumidores, desenvolvendo uma série de produtos e serviços destinados exclusivamente às crianças.

Pode se perceber a grandeza desse mercado por dados de outros países mais evoluídos na escala do consumo. Nos Estados Unidos, a criança movimenta diretamente (criançaconsumidora) cerca de 8 bilhões de dólares (MCNEAL, 1992). Deste total, 6 bilhões são 
gastos principalmente em doces, brinquedos e vestuário, os outros dois bilhões são economizados pelas crianças. Já o valor movimentado pela influência da criança atinge 130 bilhões de dólares gastos com as compras dos domicílios americanos. Vecchio (2002) atualiza essas previsões e indica que a influência da criança atinge cerca de 160 bilhões de dólares.

Considerando o tamanho desse mercado e sua capacidade como consumidor, nos variados papéis que pode assumir, pode-se concluir que este é claramente um público de relevante interesse para os acadêmicos e profissionais de marketing.

Apesar da importância econômica e social que o mercado infantil representa, percebe-se um grande desinteresse da academia brasileira de marketing pelo tema. São escassos os trabalhos acadêmicos que abordam o assunto, ao contrário do que ocorre em outros países onde a literatura é profícua e data da década de 50. Tratando da academia americana de marketing, Ward (1974, p. 1) indicava já na década de 70 que "historicamente, pesquisadores do mercado ou de consumidores, não tem se interessado muito pelo comportamento do consumidor de pessoas jovens." A partir dessa iniciativa, houve naquele país uma mudança significativa e os trabalhos relacionados ao tema se multiplicaram com o passar das décadas.

Nos Estados Unidos, é possível destacar James U. McNeal como um dos precursores dos estudos nessa área. Seus primeiros trabalhos já destacavam a importância do "novo mercado" composto por crianças entre 5 e 13 anos (MCNEAL, 1969). Segundo o autor, já na década de 60 as empresas estavam focadas no desenvolvimento de ofertas direcionadas exclusivamente para esse mercado (MCNEAL, 1969). Desde então o progresso foi significativo, se configurando em um mercado altamente profícuo para todas as organizações envolvidas na realização dos desejos deste grupo de consumidores. A primeira frase do livro de Juliet Schor (2004, p. 9) clarifica porque os estudos iniciais sobre o consumidor infantil iniciaram-se nos Estados Unidos: "[o]s Estados Unidos são a sociedade mais orientada para o consumo no mundo".

No entanto, pesquisas realizadas nas bases de dados ${ }^{1}$ e publicações nacionais indicam uma escassez de trabalhos focados no consumidor infantil sob o enfoque da disciplina de

\footnotetext{
${ }^{1}$ Fontes consultadas: Portal Scielo; Banco de Teses da Capes e Biblioteca Digital de Teses e Dissertações (BDTD). Palavras chave utilizadas: marketing infantil, marketing adolescente, consumidor infantil, consumidor adolescente, propaganda infantil, propaganda adolescente, marketing criança e marketing adolescente.
} 
marketing. Trabalhos realizados sob o âmbito de outras disciplinas, como psicologia, pedagogia, educação e sociologia, são mais freqüentes. Essa lacuna faz transparecer certo receio da academia em tratar de um tema bastante sensível. Outras áreas do conhecimento, que analisam e avaliam as ações das empresas de forma crítica, talvez tenham se sentido mais a vontade para trabalhar este tema sob esta ótica.

Diante do exposto, torna-se imperativo para a academia brasileira de marketing desenvolver trabalhos focados neste público, pois, se não for desta forma, o lapso entre o conhecimento desenvolvido em outros paises e o Brasil se tornará ainda mais significativo.

Apesar da escassez de trabalhos acadêmicos nacionais focados no mercado infantil, não se pode dizer o mesmo das empresas. São diversas as empresas nacionais e multinacionais que trabalham para oferecer uma ampla gama de produtos e serviços específicos ao segmento infantil. Diante disso, imagina-se que as empresas focadas no mercado infantil tenham trabalhado para desenvolver uma série de estratégias e processos de marketing que visam atender e seduzir este grupo de consumidores em particular. Campomar e Ikeda (2006) consideram que essa situação envolve uma falta de estudos sobre as palavras e as atividades relacionadas ao marketing de forma geral.

Como o tema foi relegado a segundo plano por um longo período, percebe-se uma defasagem entre o conhecimento prático-empírico acumulado nas empresas e o conhecimento teóricocientífico desenvolvido na academia. Dentro do escopo do marketing estratégico, cabe agora à academia de marketing dar seus primeiros passos na direção do conhecimento deste fenômeno particularmente pouco explorado. Nesse sentido, é imperativo trabalhar para identificar quais são essas estratégias e processos, para assim construir e condensar um conhecimento mais amplo sobre o tema.

De acordo com a AMA - American Marketing Association (2008b, p.1), "Marketing é a atividade, ou grupo de instituições e processos para criar, comunicar, entregar e trocar ofertas que tenham valor para os consumidores, clientes, parceiros e a sociedade em geral ${ }^{2 \%}$. Partindo dessa definição é possível compreender porque alguns autores consideram que o processo de

\footnotetext{
${ }^{2}$ Do ingles "Marketing is the activity, set of institutions, and processes for creating, communicating, delivering, and exchanging offerings that have value for customers, clients, partners, and society at large" - tradução do autor.
} 
segmentação e posicionamento pode ser entendido como uma forma de colocar o conceito de marketing em prática (WIND, 1978; DANNEELS, 1995; DIBB, 1999), e se configuram em um dos conceitos mais básicos dentro da estratégia de marketing. Dessa forma, este trabalho considera que, para melhor compreender os esforços de marketing das empresas focadas no consumidor infantil, faz-se necessário primeiramente trabalhar o conceito de segmentação e o conceito de posicionamento como forma de identificar as estratégias que estão sendo aplicadas pelas empresas que trabalham junto a este consumidor.

Convém, neste ponto, trazer os resultados da pesquisa realizada por Atauje (2000) com empresas de automação industrial. A autora abordou os conceitos de segmentação e posicionamento no segmento mencionado, sendo que os resultados encontrados denotam uma carência na plena utilização dos conceitos de segmentação e posicionamento, seja por falta de conhecimento, seja por falta de planejamento estruturado. Por outro lado, Hemzo (1992) abordou no seu trabalho o processo de posicionamento adotado por empresas alimentícias, encontrando um nível bastante superior de utilização adequada dos conceitos de marketing. Estes dois trabalhos apontam para a necessidade de maiores estudos focados nas questões relativas ao processo de segmentação e posicionamento, já que existem grupos de empresa que estão familiarizadas com estes conceitos e grupos que ainda não trabalham estes conceitos de forma concreta e organizada.

A literatura é profícua em trabalhos que abordam os conceitos de segmentação e posicionamento, porém faltam trabalhos com um foco exclusivo no mercado infantil. A necessidade de uma aproximação diferenciada para este grupo de consumidores decorre de suas peculiaridades, já que se trata de um público que está em pleno processo de desenvolvimento psicológico e social.

Hooley e Saunders (1996, p.237) acreditam que "[...] em marketing, a segmentação e o posicionamento são inseparáveis [...]". Os dois conceitos são indissolúveis porque o processo de segmentação pode ser considerado como a implementação do conceito de marketing (WIND, 1978; DANNEELS, 1995; HOOLEY e SAUNDERS, 1996), sendo o posicionamento naturalmente derivado do processo de segmentação (TOLEDO e HEMZO, 1991). Dibb (1999) compactua desta idéia, e considera o posicionamento como parte de um processo de segmentação de sucesso, pois não adianta identificar e selecionar os segmentos a serem atendidos pela empresa sem realizar um processo de posicionamento coerente com as 
características dos segmentos escolhidos. Richers (2000) também acredita que os dois conceitos devem ser trabalhados de forma conjunta, pois considera a questão do posicionamento como a operacionalização da segmentação. Lambin (2000) coloca como primeiro passo da elaboração da estratégia de marketing da empresa é a segmentação. Tomando por base os autores mencionados é possível considerar que o estudo do processo de segmentação deve ser realizado de forma concomitante com um estudo do processo de posicionamento, sendo assim este trabalho procurará estudar de forma conjunta estes conceitos.

O processo de segmentação de mercado, definido aqui como o processo de análise, agrupação e seleção de um grupo de clientes que se configura como atrativo para a empresa, enquanto direcionado ao segmento infantil, apresenta significativas diferenças. As diversidades não estão no próprio conceito de segmentação, mas sim na forma de fazer pesquisa com este grupo, nas dificuldades em identificar variáveis que possam ser utilizadas na pesquisa de segmentação, no entendimento de um consumidor que ainda está passando por um processo de desenvolvimento psicológico, físico e social. São esses fatores que tornam este trabalho valioso, pois ao melhor compreender o consumidor infantil e analisar suas diferenças, sob o enfoque do conceito de segmentação, será possível avançar o conhecimento da área de marketing.

Também cabe trazer as preocupações de autores como McDonald e Dunbar (1998), Danneels (1995) e Dibb (1999), os quais entendem que existe uma dificuldade muito grande por parte das empresas em conduzir atividades de segmentação na prática. Sendo assim, trabalhos que abordam as iniciativas realizadas por empresas serão construtivas no sentido de avaliar as dificuldades encontradas. Monte (1998) sugere que a academia de marketing deveria desenvolver um maior número de trabalhos focados nas experiências práticas de empresas no que se refere ao posicionamento. Essas considerações fundamentam a necessidade de estudar as iniciativas de segmentação e posicionamento nas mais diferentes indústrias ou mercados.

$\mathrm{O}$ "[...] posicionamento pode ser facilmente descrito como a estratégia promocional que tenta colocar uma marca em relação a uma ou mais dimensões relativas a outras marcas na mesma classe genérica." (HOUSTON e HANIESKI, 1976, p. 38). Para realizar o posicionamento mencionado, a empresa deve analisar questões estratégicas relacionadas à concorrência (ACHENBAUN, 1974), e a partir daí tentar estabelecer uma percepção diferenciada da sua 
marca perante a outras marcas disponíveis na categoria de produto em questão. Essa percepção diferenciada será transmitida para o consumidor via estratégias promocionais (HOUSTON e HANIESKI, 1976) e, sendo assim, cabe neste trabalho o esforço para identificar quais são as estratégias promocionais que as empresas utilizam perante os diferentes segmentos que compõem o mercado infantil.

DiMingo (1988) analisou a questão do posicionamento e introduziu a idéia de que o conceito de posicionamento é melhor compreendido caso seja analisado sob duas perspectivas diferente - o posicionamento psicológico (mencionado anteriormente) e o posicionamento estratégico, que envolve as atividades da empresa com relação ao restante do composto de marketing (GOUVÊA, 1991). Nesse sentido também cabe analisar as estratégias da empresa no que se refere à idéia mais abrangente de posicionamento, conforme colocada por DiMingo (1988).

O processo de desenvolvimento da criança é composto por etapas bastante distintas. Para cada uma dessas etapas se faz necessário adequar as ferramentas e as estratégias da empresa. Alguns exemplos que justificam essa necessidade: (1) crianças mais novas têm uma predisposição maior em adotar novos produtos (ROEDDER, STERNTHAL e CALDER, 1983), (2) crianças ganham maior independência e têm uma maior influência de acordo com a idade (RUMMEL et al., 2000) e (3) crianças acima de 11 anos tendem a ser responsáveis por um número maior de compras grocery ${ }^{3}$ (AHUJA et al, 1998).

Esse processo de desenvolvimento da criança também é alvo de ações regulatórias, como o Estatuto da Criança e do Adolescente, que foi instituído em 1990 pelo Governo Federal ${ }^{4}$, e o desenvolvimento do Código de Ética do $\operatorname{Conar}^{5}$ (CONAR, 2007). Este último chega a colocar esse processo de desenvolvimento como um dos fatores para o julgamento de reclamações conforme indica o parecer elaborado pelo Conselheiro Paulo Augusto de Almeida na representação 019/86 (CONAR, 2007):

É sabido que entre os 5 e 12 anos de idade as crianças experimentam - em frente a um fato -
diferentes graus de compreensão. Não se pode esperar que a consciência e o reconhecimento
dos motivos desse fato sejam os mesmos para as crianças de 5 a 7 anos, de 8 a 10 e de 11 a 12 .

\footnotetext{
${ }^{3}$ Tradução do inglês - armazém, empório, mercearia (MICHAELIS, 2007)

${ }_{5}^{4}$ LEI N ${ }^{\circ} 8.069$, DE 13 DE JULHO DE 1990.

${ }^{5}$ Conselho Nacional de Auto Regulamentação Publicitária
} 
$\mathrm{Na}$ academia, são diversos os autores que abordam a evolução da criança como indivíduo social e, conseqüentemente, como consumidoras. McNeal (1999) coloca que a criança passa por um grande desenvolvimento entre os 2 e 8 anos, adquirindo competências como consumidora. Esse processo é denominado por Ward (1974) como processo de socialização do consumidor. Durante essa fase, a criança adquire o conhecimento de como o mercado funciona, aprende o papel do dinheiro e começa a entender o significado das marcas.

Já de acordo com Roedder-John (1999), a capacidade de processar informações também é um indicativo do desenvolvimento da criança e serve como uma forma de segmentar o público infantil nas seguintes categorias: processadores estratégicos (acima dos 12 anos), processadores indicativos (7 aos 11 anos) e processadores limitados (abaixo dos 7 anos). A pesquisadora desenvolveu sua teoria aproveitando a divisão proposta por Piaget, que descreve as 4 etapas pelas quais uma criança passa até se desenvolver e se tornar um adulto: sensóriomotor (do nascimento aos 2 anos), pré-operacional (dos 2 aos 7 anos), concreto-operacional (dos 7 aos 11 anos) e formal operacional (dos 11 até a vida adulta).

Moschis e Churchill (1978) acrescentam ao estudo da criança-consumidora, colocando que o processo de socialização do consumidor é bastante influenciado pela idade ou posição no ciclo de vida e por fatores sociais.

Acuff e Reiher (1997), por sua vez, trabalham o mercado infantil em 5 grupos diferentes: do nascimento aos 2 anos (Etapa de dependência e exploratória); dos 3 aos 7 anos (estágio da emergência da autonomia); dos 8 aos 12 (estágio das regras e papéis); dos 13 aos 15 (principio da adolescência) e dos 16 aos 19 (fim da adolescência).

Apesar das divergências quanto às fases do processo, é consenso na academia a existência de disparidades no comportamento, no nível de aprendizado e no grau de interação com o mundo externo de acordo com faixas etárias é notória (PIAGET, 1959; CARMICHAEL, 1975; MONTIGNEAUX, 2003; MCNEAL, 1992; ROEDDER-JOHN, 1999; MOSCHIS e CHURCHILL, 1978; ROEDDER (1981), 1981; SIEGEL et al., 2001; ACUFF e REIHER, 1997), indicando a necessidade de estabelecer estratégias diferenciadas de segmentação e posicionamento. Os últimos, na página 5 , são os mais veementes nesse sentido:

Uma criança de 8 anos não é idêntica a uma de 10 anos, e uma de 8 anos não é idêntica a uma de 12 anos! Apesar de apenas 4 ou 5 anos separarem as idades superiores e inferiores, lembre- 
se que uma criança de 12 anos experimentou 50\% a mais na vida em relação a uma criança de 8 anos. Seria o mesmo que comparar uma pessoa de 60 anos com uma pessoa de 40 anos.

Acrescentando aos autores supracitados, Vecchio (2002, p.16) indica que "[...] a influência da criança no mercado é tal que empresas que não escutarem a opinião dessas crianças não atingirão totalmente o potencial deste mercado e certamente parte delas irá a falência." $\mathrm{O}$ autor segue, afirmando que a necessidade de entender esse segmento não está apenas fundamentada nas suas compras diretas, mas também na influência que as crianças podem gerar sobre outras categorias de produtos.

McNeal (1992) apresenta no prefácio do seu livro a necessidade das empresas adaptarem seus esforços para o mercado infantil. Para tanto, ele destaca os principais erros cometidos, os problemas encontrados para atender esse segmento e, por fim, indica as formas como a empresa pode atender e trabalhar esse mercado de forma ética e efetiva. Se no começo a idéia da criança como consumidora não era respeitada, o mesmo não se pode dizer atualmente, quando as crianças são preocupações de todos (MCNEAL, 1999).

Com base nos pontos apresentados é possível chegar-se a quatro idéias gerais:

1) $\mathrm{O}$ mercado infantil é claramente um mercado de tamanho significativo e merecedor da atenção dos acadêmicos e profissionais de marketing, sendo que o grupo composto pelos acadêmicos de marketing ainda não desenvolveu significativos estudos com enfoque na realidade nacional.

2) A criança passa por uma série de mudanças entre o seu nascimento e a entrada na adolescência. Essas mudanças fazem com que ela constitua um mercado com características singulares, e por isso deve ser cuidadosamente estudado, tanto por empresas como por estudiosos do tema.

3) A literatura de marketing identifica os conceitos de segmentação e posicionamento como primordiais para a implementação prática do conceito de marketing, apesar disso ainda não existe uma clara definição dos termos na literatura. 
4) São diversos os estudos que clamam pela realização de estudos focados na aplicação prática dos conceitos de segmentação e posicionamento. Isso decorre das dificuldades encontradas pelas empresas para traduzir os conceitos em ações práticas de implementação.

A partir das idéias apresentadas, identifica-se a necessidade do desenvolvimento de trabalhos focados na aplicação prática dos conceitos de segmentação e posicionamento, no âmbito do consumidor infantil. Disso deriva a questão de pesquisa que este trabalho buscará desenvolver: Quais são as diferentes estratégias de segmentação e posicionamento adotadas por empresas focadas no mercado infantil?

\subsection{Objetivos}

\subsubsection{Objetivo geral}

- Identificar as estratégias de segmentação e posicionamento que são apresentadas na literatura de marketing e verificar se as empresas focadas no mercado infantil seguem as sugestões da literatura.

\subsubsection{Etapas}

- Realizar levantamento bibliográfico para buscar uma definição mais adequada dos conceitos de segmentação e posicionamento.

- Realizar levantamento bibliográfico para identificar as principais sugestões e considerações da academia no que se refere às atividades de segmentação e posicionamento em empresas focadas no mercado infantil.

- Realizar uma pesquisa de campo para compreender como as empresas focadas no mercado infantil estão agindo ao segmentar e posicionar suas marcas.

\subsection{Estrutura do Trabalho}

Para atingir o objetivo proposto este trabalho está estruturado em 5 capítulos. O capitulo 1 é responsável por introduzir o tema aqui tratado, apresentando o desenvolvimento intelectual que resultou na questão de pesquisa que se busca responder. 
O capítulo 2 trata da revisão bibliográfica necessária para o desenvolvimento do trabalho, visando obter uma resposta para a questão de pesquisa proposta. Dessa forma, torna-se necessário abordar três temas distintos embora inter-correlacionados: consumo infantil, segmentação e posicionamento. A parte que trata do consumo infantil estará dividida em três partes, a primeira aparece no inicio da revisão teórica e busca dar a base para a compreensão dos conceitos de segmentação e posicionamento sob o enfoque do consumo infantil. A segunda e a terceira parte, que tratam do consumo infantil, estarão inseridas nos tópicos que englobam os conceitos de segmentação e posicionamento. Acredita-se que seja necessário desenvolver a revisão de segmentação e posicionamento de forma geral em um primeiro momento, para em seguida aprofundar a discussão destes conceitos sob a luz do consumo infantil. A importância desse tratamento em torno do tema emerge das peculiaridades deste grupo de consumidores, conforme será demonstrado posteriormente.

O capitulo 3 apresenta as considerações necessárias acerca da escolha do método adequado para obter as informações necessárias para responder a questão de pesquisa. Dentre as diversas opções disponíveis decidiu-se pelo método do caso, tendo em vista o estado atual da literatura sobre o tema e a questão de pesquisa colocada.

O capítulo 4 apresenta a análise dos dados coletados junto às empresas que se prontificaram a participar deste estudo. Os casos são aqui analisados de forma individual e posteriormente de forma comparativa para gerar uma melhor compreensão dos dados coletados.

O capítulo 5 apresenta as conclusões, limitações do trabalho, sugestões de pesquisas futuras e implicações gerenciais. Essa estrutura é apresentada na Ilustração 1. 


\section{CAPÍTULO 1}

1. Introdução: importância do trabalho, justificativa e questão de pesquisa.

2. Objetivos: objetivo geral, etapas a serem cumpridas e estrutura do trabalho.

Com base na questão de pesquisa defini-se a literatura que é apresentada na revisão teórica, objetivando encontrar uma resposta para o problema de pesquisa.

\section{CAPÍTULO 2}

Revisão Teórica

Mercado Infantil

Segmentação de Mercado

Posicionamento de Mercado

Como não foi possível responder o problema de pesquisa por meio da revisão teórica, parte-se para um estudo de campo que busca aprofundar o conhecimento sobre o fenômeno.

\section{CAPÍTULO 3}

\section{Escolha do Método de Pesquisa}

Escolha do Método

Definição da Estratégia de Pesquisa

Planejamento da Pesquisa

$$
\square \begin{aligned}
& \text { A partir dos dados coletados foi conduzido um esforço de análise para } \\
& \text { responder o problema de pesquisa. }
\end{aligned}
$$

\section{CAPÍTULO 4}

\section{Análise dos Dados}

Apresentação Individual dos Casos (Grow Jogos e Brinquedos, Brinquedos Pica Pau, Mitra Officina de Criação).

Análise Cruzada dos Casos

$$
\sqrt{\begin{array}{l}
\text { A partir da análise dos dados são apresentadas as principais } \\
\text { considerações sobre o trabalho. }
\end{array}}
$$

\section{CAPÍTULO 5}

Considerações Finais

Conclusões

Limitações do Trabalho

Sugestões de Pesquisas Futuras

Implicações Gerenciais

Ilustração 1 - Estrutura do Trabalho

FONTE: Elaborado pelo autor. 


\section{REFERENCIAL TEÓRICO}

Nesta etapa do trabalho serão abordados os temas relevantes para a consecução do objetivo proposto inicialmente, ou seja, Identificar as estratégias de segmentação e posicionamento que são apresentadas na literatura de marketing e verificar se as empresas focadas no mercado infantil seguem as sugestões da literatura. Sendo assim, inicia-se com informações referentes à importância do mercado infantil, para posteriormente, abordar os conceitos de segmentação e posicionamento. Optou-se por iniciar esta etapa com a questão do consumidor infantil como forma de posicionar o leitor para a correta compreensão das etapas posteriores do trabalho. Cabe salientar que os tópicos que tratam de segmentação e posicionamento serão finalizados com um sub-tópico que trata da literatura especializada no mercado infantil com enfoque direcionado para os dois conceitos.

\subsection{Importância do mercado infantil}

De acordo com McNeal (1992), é a partir da década de 80 que a criança surge como um fenômeno significativo. Este tópico do trabalho busca analisar os eventos sócio-culturais que explicam essa transformação, bem como destacar a importância dessa especialização para acadêmicos e praticantes do marketing.

Para o mercado existem algumas regras simples que indicam se determinado segmento é merecedor de esforços por parte das empresas. Primeiramente, esse segmento deve ter necessidades ou desejos específicos, deve ter recursos financeiros para gastar e ser composto por um determinado número de indivíduos para tornar os investimentos neste segmento rentáveis (MCNEAL, 1992). O autor analisa que, nos Estados Unidos, essas características ainda não podiam ser utilizadas para identificar o segmento infantil até o final da $2^{\text {a }}$ Guerra Mundial. Após o término da Guerra, em 1946, deu-se naquele país o fenômeno denominado Baby Boom ${ }^{6}$ ocorre. Conforme dados apresentados por McNeal (1992), o número de crianças passa de 10 para 15 milhões entres 1946 e 1951. Esse fator trouxe o tamanho necessário para que este segmento fosse considerado cada vez mais atrativo.

\footnotetext{
${ }^{6} \mathrm{O}$ fenômeno do Baby Boom refere-se ao crescimento da taxa de natalidade no pós II Guerra Mundial. Esse acontecimento foi mais sentido em países que tiveram uma maior participação na guerra, principalmente os Estados Unidos.
} 
As questões referentes à renda, às necessidades e aos desejos vieram a seguir. O pós-guerra trouxe consigo uma percepção de que a vida deveria ser vivida no curto prazo, com gratificações imediatas (MCNEAL, 1992). Essa sensação foi rapidamente direcionada para as crianças que se multiplicavam na América, fazendo com que os pais sentissem que as crianças mereciam ter renda própria para suprir suas necessidades.

Com democratização da televisão, durante a década de 50, surge um meio de comunicação que permitiu às empresas terem um canal efetivo para acessar e se comunicar com esse segmento crescente de crianças, dando origem a uma inundação de propagadas e apelos direcionados às crianças (MCNEAL, 1992).

Na segunda metade da década de 60, os infantes já representavam gastos próprios da ordem de 2 bilhões de dólares anuais (MCNEAL, 1992). Neste momento, as exigências do mercado, para considerar o mercado infantil como merecedor de atenção, se solidificaram.

A década de 70 assistiu ao crescimento das crianças nascidas durante o período do Baby Boom. Essas crianças foram ensinadas a consumir, incutiu-se em suas mentes que parte do prazer e da satisfação em viver provinha do consumo (MCNEAL, 1992). Durante esse período, surgem, por parte da academia de marketing, severas preocupações com questões relacionadas à socialização do consumidor. O artigo Consumer Socialization, de Scott Ward, publicado no Journal do Consumer Research em 1974 é considerado por John (1999) como a pedra fundamental que incentivou o crescimento dessa linha de pesquisa. O próprio governo norte-americano direcionou esforços no sentido de educar as crianças a se tornarem consumidores sagazes, educados, e conscientes dos seus direitos e obrigações no mercado (JOHN, 1999).

A Ilustração 2, apresentada a seguir, resume os fatos principais ocorridos ao longo do período apresentado. 


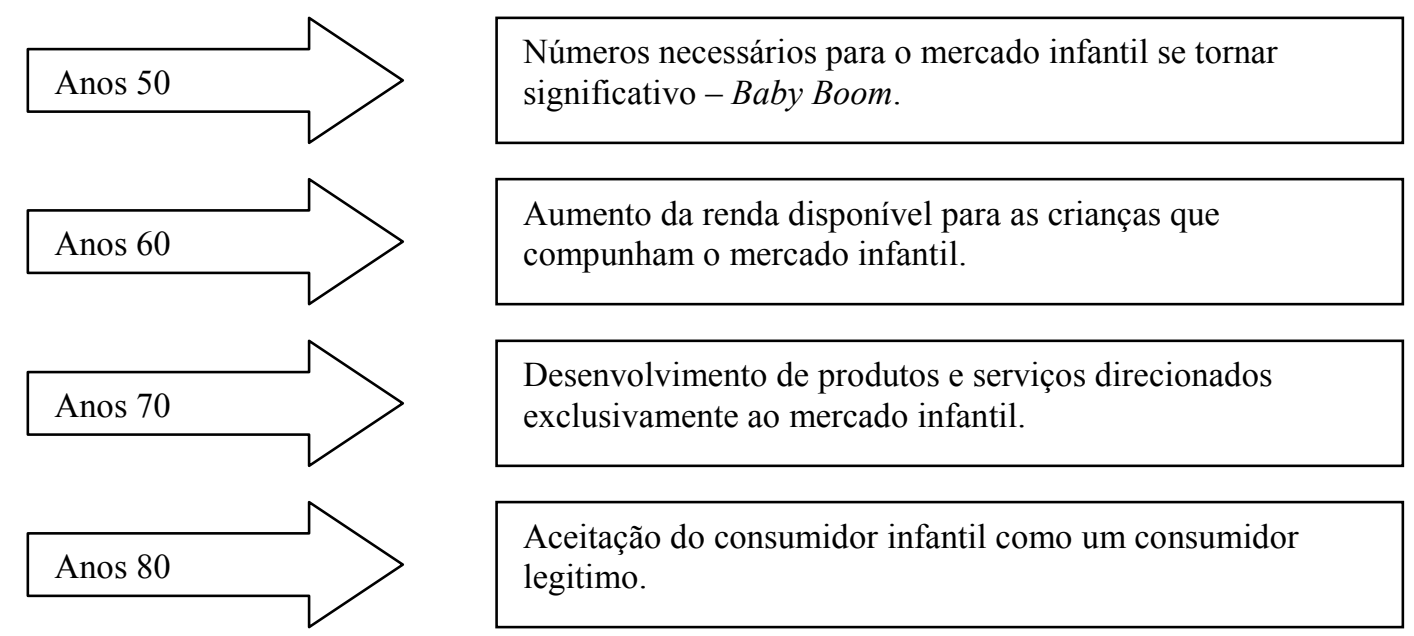

Ilustração 2 - Desenvolvimento do segmento infantil nos Estados Unidos (1950-1980) FONTE: Adaptado de MCNEAL; 1992, p. 4-6.

Com a chegada dos anos 80, uma série de mudanças sociais acontece nos Estados Unidos, que culminaram na aceitação, por definitivo, da criança como um consumidor legítimo (MCNEAL, 1992):

- Menor número de crianças por pai ou mãe: com a chegada dos anos 80 , surge uma nova forma de pensar. Os pais da época do Baby Boom tiveram uma média de 3 filhos por casal, já as crianças nascidas durante o Baby Boom têm uma média inferior a dois filhos por casal. Essa mudança de mentalidade está fundamentada na necessidade desses pais em dar mais para seus filhos. Esse fenômeno diminuiu a taxa de natalidade no país, mas gerou crianças com uma renda cada vez mais elevada em relação às gerações anteriores.

- Menor número de pais por criança: uma combinação de divórcios e mães solteiras gerou um segmento considerável de domicílios onde só reside um dos pais. Nesses domicílios esperava-se que a criança assumisse um papel de parceiro, realizando algumas tarefas que anteriormente eram de responsabilidade do pai ou mãe ausente. Dessa forma, as crianças que viviam nesses tipos de domicílio passaram a ter um contato mais rápido e mais profundo com o consumo.

- Adiamento da paternidade ou maternidade: com o aumento da importância da carreira, tanto para a mulher como para o homem, tornou-se natural adiar a procriação. Essa espera criou uma situação onde a criança era esperada com 
ansiedade, intensificando os laços emotivos entre progenitores e filhos. Essa espera também fez com que as crianças nascessem em domicílios onde os pais já estivessem com a carreira mais desenvolvida e, conseqüentemente, com uma renda superior.

- Famílias onde ambos os pais trabalham: com o aumento da inserção da mulher no mercado de trabalho, se tornou normal a existência de famílias onde ambos os pais trabalhavam. Naturalmente, a renda dessas famílias aumentou em relação a famílias onde o provedor é um só. O resultado foi um domicílio com uma maior renda disponível para as poucas crianças que ali foram geradas.

Essas mudanças se prolongaram durante os anos 90, trazendo uma importância ainda maior para o segmento infantil. Em seu livro de 1999, McNeal revê as colocações feitas em 1992 e agrega alguns novos fatores ou mudanças que aumentaram ainda mais a relevância do segmento infantil. Essas mudanças são apresentadas no Quadro 1.

Percebe-se que, em relação às colocações de 1992, McNeal (1999) agrega à questão do papel dos avós na formação das crianças, o fator culpa e a preocupação dos pais com o futuro das crianças. Nesse sentido, o crescimento do número de domicílios com ambos os pais trabalhando, fenômeno que teve início nos anos 80, tornam a criação dos filhos mais complicada. Sendo assim, é natural o crescimento da importância dos avós na criação dos seus netos. Esses avós, com uma renda superior à disposição, tendem a direcionar parte dessa renda para as crianças.

O fator culpa surge por parte de pais divorciados que não conseguem mais ter uma convivência constante com os filhos. Esses pais distantes direcionam parte da sua renda para suprir com bens e dinheiro a ausência. O último fator apresentado por McNeal (1999), tem sua origem nas diversas crises econômicas atravessadas pelos Estados Unidos e no aumento da competitividade do mercado de trabalho. 
Quadro 1 - Fatores que explicam o crescimento da importância do consumidor infantil

\begin{tabular}{|c|c|}
\hline Fator & Explicação \\
\hline $\begin{array}{l}\text { Aumento do número de } \\
\text { provedores por família }\end{array}$ & $\begin{array}{l}\text { Com o aumento da participação da mulher no ambiente de trabalho é cada vez } \\
\text { mais comum encontrar famílias onde ambos os pais trabalham. }\end{array}$ \\
\hline $\begin{array}{l}\text { Diminuição do número } \\
\text { de crianças por família }\end{array}$ & $\begin{array}{l}\text { A queda da taxa de fertilidade tem gerado famílias com um número cada vez } \\
\text { menor de filhos. Dessa forma os pais têm mais renda disponível para gastar } \\
\text { por criança. }\end{array}$ \\
\hline $\begin{array}{l}\text { Pais mais idosos (e mais } \\
\text { ricos) }\end{array}$ & $\begin{array}{l}\text { No passado (década de } 60 \text { e } 70 \text { ) existia a expectativa de que a mulher deveria } \\
\text { ter filhos antes de atingir os } 30 \text { anos. Essa perspectiva mudou. Atualmente as } \\
\text { famílias têm filhos com idades cada vez mais avançada. Isso faz com que a } \\
\text { criança nasça numa família estruturada, com ambos os pais trabalhando, com } \\
\text { carreiras consolidadas, ou seja, com uma renda superior. }\end{array}$ \\
\hline Famílias desestruturadas & $\begin{array}{l}\text { Numa família onde os pais são separados o número de parentes dispostos a } \\
\text { presentear a criança aumenta. Caso a criança passe parte do tempo com o pai } \\
\text { e parte do tempo com a mãe ocorre a necessidade de comprar produtos mais } \\
\text { corriqueiros de forma duplicada. }\end{array}$ \\
\hline Mães solteiras & $\begin{array}{l}\text { É cada vez mais comum encontrar lares chefiados por mães solteiras. Isso faz } \\
\text { com que a criança tenha que assumir responsabilidades mais rapidamente que } \\
\text { o normal, tendo então de realizar compras, cuidar da casa, resumindo, ter um } \\
\text { papel mais participativo. Nesses casos também pode acontecer da criança ter } \\
\text { outra renda provinda do pai ausente. }\end{array}$ \\
\hline $\begin{array}{l}\text { Avós cada vez mais } \\
\text { importantes }\end{array}$ & $\begin{array}{l}\text { Com a presença cada vez maior da mulher no mercado de trabalho torna-se } \\
\text { necessário encontrar quem cuide das crianças. Os avós são candidatos } \\
\text { naturais a este trabalho. É comum também estes avós terem parte da renda } \\
\text { disponível, a qual acaba sendo direcionada para a criança. }\end{array}$ \\
\hline O Fator Culpa & $\begin{array}{l}\text { Pais solteiros ou divorciados carregam consigo a culpa de não estar presente } \\
\text { na criação do filho. Essa situação gera a sensação de culpa, a qual é } \\
\text { canalizada para a compra de bens e serviços por meio do conceito de Quality } \\
\text { Time. O pai quer aproveitar o máximo o tempo com a criança, não poupando } \\
\text { esforços financeiros para tal. }\end{array}$ \\
\hline $\begin{array}{l}\text { Pais preocupados com o } \\
\text { futuro das crianças }\end{array}$ & $\begin{array}{l}\text { Os pais, provindos de uma geração que atravessou diversas crises, entendem } \\
\text { que apenas com um preparo excepcional a criança poderá sobreviver no } \\
\text { mercado de trabalho. Essa preocupação reverte em aulas de idiomas, } \\
\text { computação, esportes, musica, etc. }\end{array}$ \\
\hline
\end{tabular}

FONTE: Adaptado de MCNEAL; 1999, p. 19-22.

Os dados aqui apresentados são todos de origem norte-americana, tratando de uma realidade distinta daquela existente no Brasil. Infelizmente, são escassos os trabalhos focados no desenvolvimento do mercado infantil no Brasil. De qualquer forma, não é difícil entender que alguns fatores apresentados neste tópico do trabalho podem ser entendidos no contexto nacional, como por exemplo: participação maior da mulher no mercado de trabalho, diminuição do número de filhos por família, crises econômicas, fator culpa, famílias desestruturadas e mães solteiras. 


\subsection{Segmentação de mercado}

Nesta etapa do trabalho, serão abordados os temas relevantes ao conceito de segmentação de mercado e aos processos de segmentação, a escolha dos critérios de segmentação, assim como outros temas relevantes para a melhor compreensão deste trabalho.

\subsubsection{Conceito de segmentação de mercado}

É parte inerente a todo trabalho acadêmico a definição clara e precisa dos conceitos sendo abordados. Dessa forma, este trabalho buscou coletar na literatura de marketing as diferentes formas com que o conceito de segmentação foi abordado. A partir deste tipo de esforço, é possível compreender as diferentes visões que englobam o conceito e também perceber uma eventual evolução do significante ao longo do tempo. Sendo assim, no APÊNDICE 1, são apresentadas as inúmeras definições já propostas na literatura. A partir dessas informações é construído o texto apresentado a seguir, que trata da evolução do conceito ao longo do tempo.

O uso de estratégias de segmentação é uma ação natural que empresas americanas já realizam desde o advento da produção em massa (BRANDT, 1966), mas foi somente na década de 50 que o conceito foi criado e passou a ser estudado pela academia de marketing. Isso não aconteceu antes pois é somente na década de 50 que os mercados passam a assumir uma característica fragmentada (BRANDT, 1966). Até então, esclarece o autor, restrições econômicas e geográficas não permitiam que as empresas tivessem uma atuação externa do seu entorno geográfico.

Durante a década de 30 e 40, uma série de avanços no transporte de carga, redes de comunicação e empacotamento gradualmente diminuíram as restrições existentes, permitindo que as empresas atuassem em mercados mais abrangentes (BRANDT, 1966). A partir dessa época se admite que o conceito de "segmentação de mercado é crucial para manter uma empresa competitiva" (CAMPOMAR e GIL, 2006, p.11).

O conceito de segmentação surge na literatura durante a década de 50. O desenvolvimento inicial do conceito de segmentação é verificado no trabalho de Smith (1956). O autor parte da idéia da curva da demanda, que até então era vista como única pelos economistas, e desagrega essa curva em uma série de curvas distintas que configurariam os diferentes segmentos que compõem o mercado como um todo. Por meio da estratégia de segmentação, a empresa tem 
uma melhor compreensão das diferentes necessidades de seus clientes (SMITH, 1956). Beane e Ennis (1987) indicam que o conceito de segmentação está fundamentado na premissa de que o mercado não é homogêneo, ou seja, existem diferentes grupos de consumidores com características e preferências distintas. A idéia da segmentação aborda a questão das dificuldades que a empresa teria em atender todos os segmentos do mercado, sendo preferível focar em determinado segmento para aumentar as chances de sucesso da empresa por meio da melhor alocação de recursos (TOLEDO e HEMZO, 1991; HOOLEY e SAUNDERS, 1996).

Já na década de 60, Brandt (1966), também com uma influência da economia, trata da segmentação com sendo a elasticidade promocional, ou seja, reações similares aos esforços de marketing por um determinado tempo. A definição do autor tem como principal aporte a questão da limitação de tempo. São poucos os autores que lembram que os esforços de segmentação têm um prazo limitado de validade, pois com o tempo muda o mercado e mudam os consumidores e suas preferências/características.

Andreasen (1966) muda o foco e trata das características dos compradores, indicando a necessidade de diferenciar as estratégias de marketing da empresa visando o aumento dos lucros. O autor compara duas estratégias - atender o mercado de forma massificada e atender o mercado de forma mais focada, avaliando que a última opção seria mais adequada e lucrativa.

Claycamp e Massy (1968) trazem uma idéia que ajuda a compreender como deve acontecer o processo de segmentação. Os autores acreditam que o processo de tratar da agregação e não da desagregação. Tomando essa visão como base, a empresa deveria selecionar algumas variáveis que melhor definissem o consumidor da empresa, algo como um consumidor ideal e, a partir daí, buscar consumidor com características similares.

A definição de Claycamp e Massy (1968) tem muita similaridade com o processo de agrupação utilizado pela técnica estatística de análise de conglomerados. É possível perceber no trabalho de Barnett (1969) as origens do conceito de segmentação apresentado por Lambin (2000). Barnett (1969) parte de um mercado mais amplo que consome determinado produto e indica que é possível dividir esse mercado mais amplo em segmentos menores que possuem necessidades e desejos mais específicos. Esses primeiros estudos sobre o conceito de 
segmentação buscaram sedimentar a idéia de que, ao melhor compreender o mercado e os sub-segmentos que o compõem, é possível trazer resultados superiores para a empresa.

Na década de 70, Johnson (1971) trabalha o relacionamento entre o processo de segmentação e a capacidade da empresa, com base nos resultados do processo, identificar potenciais posicionamentos e suas respectivas demandas. Este é um dos primeiros trabalhos que indica de forma clara a relação entre a segmentação e o posicionamento. Wind e Douglas (1972) também são inovadores na definiç̧ão do conceito, indicando a praticidade do conceito para mercados internacionais, pois seja qual for o mercado, a idéia de encontrar grupos de compradores que reagem de forma similar aos esforços de marketing se mantém. Assael e Roscoe (1976) estabelecem a segmentação como uma ferramenta estratégica de marketing que serve para definir mercados e alocar recursos. Neste período, o conceito passa a ganhar uma importância maior, tornando-se peça chave da estratégia de marketing.

Já adentrando a década de 80, Beane e Ennis (1987) apresentam a idéia de que a segmentação é fundamentada na premissa de que o mercado não é totalmente homogêneo, ou seja, devem existir grupos de consumidores que tenham preferências peculiares. Para os autores, a segmentação serve para buscar novas oportunidades de produtos ou grupos de consumidores que poderiam ser receptivos ao reposicionamento de produtos atuais. Além disso, a segmentação pode servir para criar propagandas melhoradas por meio do melhor entendimento dos consumidores.

A idéia de criar uma propaganda melhorada é sinal de que o conceito de posicionamento já começa a ser percebido como altamente relacionado com a segmentação. Tynan e Drayton (1987) indicam que, a partir de determinadas características, é possível agrupar os consumidores em segmentos homogêneos para àquelas características. Essa percepção abre espaço para a existência de segmentos em que grupos ainda menores existem. Naturalmente, a redução do segmento a conjuntos cada vez menores não é necessariamente a melhor alternativa, pois pode ser inviável financeiramente atender a grupos muito pequenos. Se for levada ao extremo, a idéia de segmentação seria possível chegar ao consumidor individual, pois, possivelmente, cada indivíduo terá uma pequena diferença em relação ao seu par mais próximo. 
Já durante a década de 90, algumas reflexões sobre o lado estratégico da segmentação começam a tomar forma. Ao conduzir um esforço de segmentação, a empresa está reconhecendo que não poderá atender a todos os segmentos (TOLEDO e HEMZO, 1991), pois entenderá que alguns segmentos são mais atrativos que outros. Os autores também consideram que essa limitação pode ser também de recursos, ou seja, a empresa identifica alguns segmentos que lhe são potencialmente atrativos, mas escolhe atender apenas a uma parte deles em função das restrições que a estrutura da empresa e o ambiente lhe impõem.

Richers (1991a) recupera a idéia de que a segmentação é adequada para identificar segmentos com características e vontades similares. O conceito de Richers (1991a), e muitos outros anteriormente apresentados, está fundamentado na premissa de que as características dos consumidores explicam o seu comportamento, ou seja, pessoas com características similares irão necessitar e desejar produtos similares. A grande dificuldade aqui está em determinar quais características similares ajudam a explicar as preferências dos consumidores.

De forma análoga, é possível entender que, dependendo do nível de profundidade da segmentação realizada, a satisfação de cada um dos consumidores com a oferta da empresa variará. Dependendo do nível de segmentação a empresa terá segmentos mais homogêneos e menos homogêneos. A indicação do nível de profundidade da segmentação é uma decisão que remete a uma análise estratégica do mercado para identificar as opções que os concorrentes oferecem. Se as opções são poucas, a empresa pode trabalhar num nível de segmentação menos exigente. Se existem outras empresas oferecendo inúmeras ofertas para os clientes, faz-se necessário aprofundar o nível da segmentação para identificar as necessidades e desejos mais específicos de grupos menores, que ao ter uma oferta mais adequada ao que procuram, possivelmente trocarão de fornecedor.

Em função dessas reflexões, a idéia da segmentação encontrar grupos homogêneos (DANNEELS, 1995; WEINSTEIN, 1995) precisa ser relativizada. Esse tipo de dificuldade pode explicar a razão que faz com que a implementação prática do conceito de segmentação se torne difícil de ser compreendida por algumas empresas. Hooley e Saunders (1996) trazem um importante aporte para essa discussão, esclarecendo que os segmentos devem ter algum nível de similaridade, mas também devem ser alcançáveis por uma oferta distinta, ou seja, deve ser possível para a empresa se comunicar e oferecer uma oferta especifica para este grupo. Caso isso não seja possível, a escolha desse determinado segmento não é adequada. 
McDonald e Dunbar (1998) tornam clara a idéia de que o processo de segmentação deve ser seguido pela implementação do composto de marketing. Mais uma vez surge a questão da identificação de um processo de trabalho, que começa com a segmentação, passa pelo posicionamento e termina com a implementação prática do composto de marketing adequado ao segmento escolhido.

No fim dessa década, Lambin (2000) traz uma nova visão para o conceito de segmentação, introduzindo a idéia da macro segmentação e da micro segmentação. Até o momento não estava claro, tanto para a academia, como para os profissionais de marketing, o ponto de corte para iniciar um processo de segmentação. A idéia de Lambin (2000) parte de uma escolha inicial do mercado de atuação de uma empresa. Por exemplo, uma empresa que decide oferecer notebooks. A empresa já tomou uma primeira decisão, que está mais relacionada ao processo estratégico da empresa do que ao processo de segmentação em si. Numa segunda etapa, denominada de micro segmentação, a empresa irá analisar o mercado de notebooks para identificar os segmentos que compõem esse mercado, tendo assim a possibilidade de ajustar a sua oferta para estes segmentos identificados. O conceito, conforme apresentado por Lambin (2000), permite que a empresa tenha uma melhor compreensão do processo como um todo. Até então o empresário poderia ficar confuso, pois não teria a completa compreensão do momento onde utilizar o processo de segmentação.

Durante a década atual (década de 00), os autores trabalharam basicamente a idéia geral de que a segmentação serve para encontrar grupos com características similares, possuidores de desejos e necessidades similares, que reagirão de forma similar às atividades de marketing da empresa (SCHIFFMAN e KANUK, 2000; HOOLEY et al., 2001; BRADLEY, 2003; CHURCHILL e PETER, 2005; KOTLER e ARMSTRONG, 2005; FERRELL e HARTLINE, 2005; KOTLER e KELLER, 2006).

A análise acima permite resumir o conceito de segmentação em 3 princípios básicos:

1 - É um processo de agregação de consumidores, com base em determinadas características. 
2 - Ao agrupar os consumidores, espera-se identificar grupos que possuem necessidades e desejos similares.

3 - Estes grupos, por possuírem características similares, também terão reações similares aos estímulos de marketing, assim como terão necessidades e desejos similares.

Hooley e Saunders (1996, p.214) apresentam algumas considerações sobre as vantagens que podem ser adquiridas pelas empresas que realizam o processo de segmentação:

A segmentação é uma abordagem muito útil para o marketing de uma empresa menor. Ela possibilita visar mercados adequados às competências da empresa e torna possível à empresa menor criar, dentro do mercado, um nicho defensável.

Ela ajuda a identificar lacunas no mercado: isto é, segmentos não atendidos ou subatendidos. Estes podem fornecer áreas para o desenvolvimento de novos produto ou a extensão da gama de produtos ou serviços existentes.

Em mercados maduros ou em declínio, será possível identificar segmentos específicos ainda em crescimento. A concentração nos segmentos em crescimento quando o mercado geral está em declínio é uma importante estratégia nos estágios finais do ciclo de vida do produto.

A segmentação permite ao profissional de marketing adequar melhor o produto ou serviço Às necessidades do mercado-alvo. Desta maneira, pode-se construir uma posição competitiva mais forte.

Nunca é demais enfatizar os perigos de não segmentar o mercado quando os concorrentes o fazem. As vantagens competitivas assinaladas acima podem ser perdidas para a concorrência se a empresa deixa de aproveita-las. Uma empresa que pratique uma estratégia de mercado de massa em um mercado claramente segmentado em oposição a concorrentes de estratégia objetiva e delimitada pode se ver numa situação complicada.

McDonald e Dunbar (1998, p.29) também fazem um esforço para apresentar as principais vantagens da realização do processo de segmentação:

Reconhecer as diferenças dos consumidores como chave para um marketing de sucesso, pois pode levar a um maior aderência entre as necessidades dos consumidores com os produtos ou serviços da empresa.

Segmentação pode levar para o marketing de nicho, quando apropriado, onde a companhia pode atender todas ou quase todas as necessidades dos consumidores naquele segmento-nicho. Isso pode resultar na dominação do segmento, algo que quase nunca é possível no mercado total.

Segmentação pode levar para a concentração de recursos em mercados onde a vantagem competitiva é maior o os retornos mais altos.

Segmentação pode ser usada para ganhar uma vantagem competitiva por considerar os mercados de forma diferente dos seus competidores. 
Por meio da segmentação, você pode vender sua companhia como especialista nos segmentos de mercado escolhidos, com um melhor entendimento das necessidades dos consumidores, dessa forma oferecendo produtos/serviços com vantagens sobre os produtos da concorrência.

A partir das vantagens listadas por Hooley e Saunders (1996) e McDonald e Dunbar (1998), percebe-se a importância do conceito de segmentação para a academia de marketing. Como visto anteriormente, essa visão não é nova, sendo já disseminada no momento em que o conceito foi desenvolvido. Naquele momento da história, quando o conceito de segmentação foi construído, multiplicaram-se os trabalhos focados na estratégia de segmentação de mercado (p.e.: ANDREASEN, 1966; BARNETT, 1969, BASS et al.., 1968; BOWMAN e MCCORMICK, 1961; BRANDT, 1966; CLAYCAMP e MASSY, 1968). Nessa época também, foram conduzidos trabalhos analisando quais técnicas estatísticas seriam mais adequadas para examinar dados provenientes de pesquisas de segmentação, como, por exemplo, nos trabalhos de Assael (1970), Bass et al.. (1968) e Barnett (1969), assim como trabalhos focando na aplicabilidade do conceito para mercados internacionais (WIND e DOUGLAS, 1972).

Ao desenvolver estratégias de segmentação, o profissional de marketing está desenvolvendo iniciativas no sentido de realmente colocar em prática o conceito de marketing ${ }^{7}$ (WIND, 1978; DANNEELS, 1995). Ao compreender melhor seus consumidores e suas necessidades e desejos mais específicos, a empresa têm a capacidade de desenvolver sua oferta de forma mais apropriada, conseguindo assim atender os seus clientes da melhor forma. Sendo assim, é natural colocar a segmentação de mercado como ponto de partida para o desenvolvimento do planejamento de marketing de uma empresa (WEINSTEIN, 1995; MCDONALD e DUNBAR, 1998). Hooley e Saunders (1996, p.192) afirmam que "a segmentação é a extensão lógica do próprio conceito de marketing" quando sé consegue encontrar segmentos com diferentes necessidades e desejos. Ao analisar o mercado e selecionar um grupo de consumidores para ser trabalhado, a empresa dá o primeiro passo no seu processo de entrega de um produto ou serviço. Todas as etapas deveriam ser decorrentes desta primeira iniciativa da empresa, mesmo porque a segmentação de mercado pode ser entendida como uma vantagem competitiva da empresa (MCDONALD e DUNBAR, 1998).

\footnotetext{
${ }^{7}$ Marketing é a atividade, grupo de instituições, e processo para criar, comunicar, entregar e trocar ofertas que tem valor para os consumidores, clientes, parceiros e a sociedade em geral (AMA, 2008).
} 


\subsubsection{O processo de segmentação de mercado}

Richers (1991a) entende a segmentação como uma questão estratégica, onde a empresa, de forma consciente, pondera as características do mercado e escolhe atender determinados segmentos, imaginando que terá um resultado melhor ao direcionar os recursos disponíveis para uma seleção restrita de consumidores. Seguindo a mesma linha de Richers (1991a), o processo de segmentação de mercado possibilita o desenvolvimento de estratégias mais focadas no público selecionado, gerando lucros superiores em comparação com as estratégias que tratam o mercado como sendo um mercado de massa (ANDREASEN, 1966; WIND, 1978). Essas estratégias mais focadas podem ser traduzidas, na visão de Beane e Ennis (1987), na (a) busca de novas oportunidades para novos produtos ou grupos de consumidores que seriam receptivos para um reposicionamento de produto ou (b) criar mensagens melhoradas por meio do melhor entendimento do consumidor.

Um dos primeiros passos a serem tomados pela empresa que pretende desenvolver o processo de segmentação de mercado é realizar uma pesquisa de segmentação. O objetivo da pesquisa de segmentação é compreender melhor o mercado e encontrar nichos que signifiquem uma oportunidade de negócio para a empresa (WEINSTEIN, 1995). A partir dessa iniciativa, é necessário verificar os ganhos em vendas e avaliar se são superiores aos gastos necessários para focar em determinado(s) segmentos(s) (WIND e DOUGLAS, 1972). Importante lembrar que os resultados provenientes de uma pesquisa de segmentação representam o mercado no momento da pesquisa. Sendo assim, a empresa precisa estar atenta para mudanças que possam ocorrer nos consumidores, tanto em tamanho, como em preferências relacionadas à oferta da empresa (CALANTONE e SAWYER, 1978).

Na Ilustração 3, Richers (1991a) apresenta as duas opções existentes para uma empresa no que se refere à questão da segmentação. 

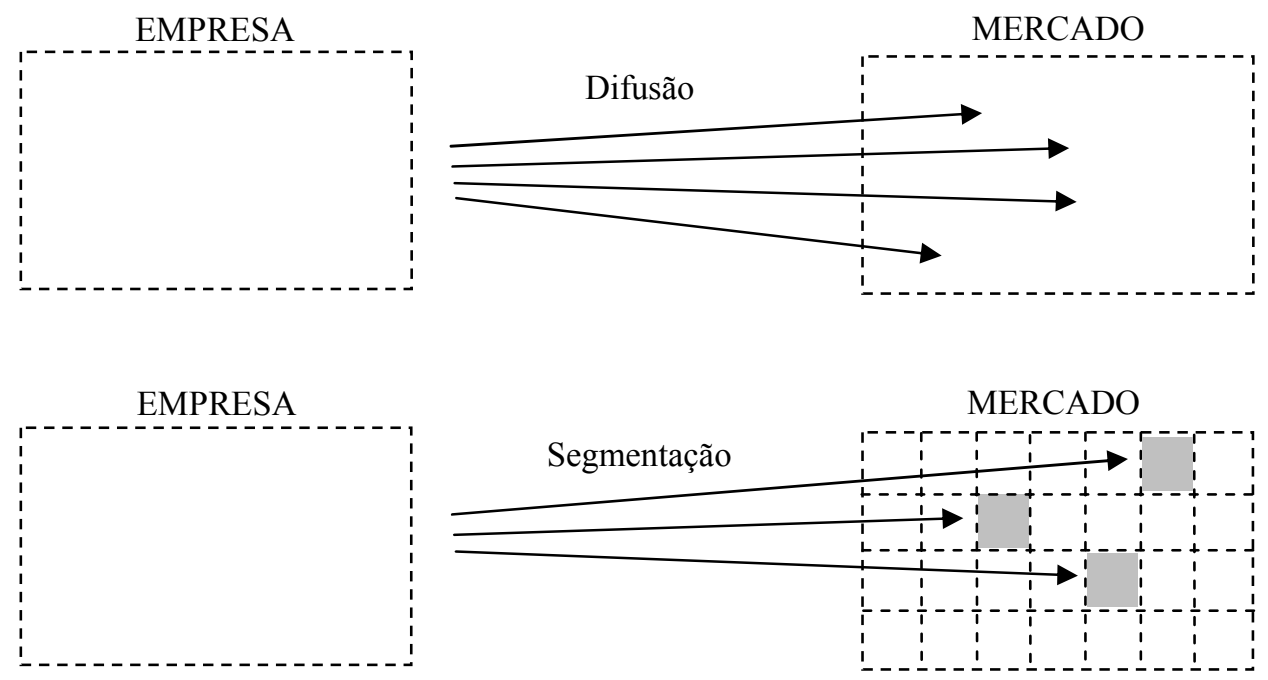

Ilustração 3 - Difusão versus Segmentação

FONTE: Adaptado de RICHERS; 1991a, p.15.

A primeira diz respeito à Difusão, que

[...] consiste em espalhar os produtos pelo mercado afora, sem se preocupar com quaisquer diferenças que possam existir entre os compradores em potencial. São os produtos em si, em particular a maneira como eles se diferenciam de outras ofertas semelhantes, que devem se "impor" ao mercado e assegurar o sucesso da empresa (RICHERS, 1991a, p.15).

A segunda trata da Segmentação, que "parte da premissa inversa - a demanda não é uniforme, mas sim heterogênea, o que justifica uma concentração dos esforços de marketing em determinadas fatias específicas do mercado" (RICHERS, 1991a, p.15).

Weinstein (1995) aborda essa questão com base nos desdobramentos estratégicos que a decisão representa. Caso a empresa decida pela difusão, ou seja, tratar todo o mercado como potenciais consumidores, ela estará utilizando uma estratégia de marketing não diferenciada. Weinstein (1995) sinaliza que essa opção, pela difusão, é mais adequada para empresas que trabalham em um ambiente monopolista.

Já Brandt (1966) coloca a questão da escolha entre a difusão e a segmentação como resultante de uma análise econômica. Hooley e Saunders (1996) também acreditam que a opção pela não segmentação seja de caráter econômico, tendo em vista os ganhos de escala oriundos da não adequação do mix de marketing da empresa para diferentes segmentos. Nestes casos, continuam os autores, a empresa estará atuando na expectativa de conseguir captar um número suficiente de clientes nos diferentes segmentos. 
Lambin (2000), por sua vez, considera que em apenas alguns poucos casos a empresa consegue satisfazer todos os consumidores com uma única oferta, sendo na maioria dos casos necessário a diferenciação de acordo com os diferentes segmentos. Apesar de Lambin (2000) sinalizar que na maioria dos casos é necessário trabalhar a segmentação, ele deixa espaço para, em alguns casos, a empresa optar pela não segmentação. Aproveitando as colocações dos pesquisadores sobre o tema, de forma geral, percebe-se que a escolha pela segmentação deve ser feita a partir de uma análise das capacidades da empresa e das características do mercado, não sendo então a segmentação obrigatória para todas as empresas. Abre-se, a partir de então, a possibilidade para intensidades variadas de diferenciação, como exposto por Kotler e Armstrong (2005) e Richers (1991a), condensado na ilustração abaixo:

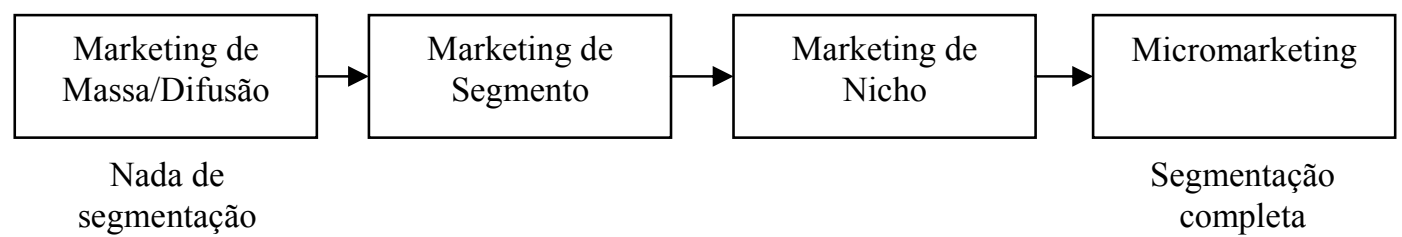

Ilustração 4 - Níveis de segmentação de mercado FONTE: Adaptado de KOTLER e ARMSTRONG; 2005, p.173 e RICHERS; 1991a, p.15.

O nível de segmentação a ser efetuado pela empresa vai depender das características do mercado e do produto que serão oferecidos aos consumidores. O conceito de micromarketing é explicado por Kotler e Armstrong (2005, p. 174) como sendo a "prática de desenvolver produtos e programas de marketing sob medida para atender aos gostos das pessoas aos gostos de pessoas e locais específicos", incluindo nesse ponto o marketing local e o individual. $\mathrm{O}$ marketing individual seria o extremo oposto ao marketing de massa ou difusão. Neste extremo, torna-se necessário customizar a oferta da empresa aos desejos e necessidades individuais dos consumidores (KOTLER E ARMSTRONG, 2005).

A idéia do marketing individualizado somente ser torna factível com a existência de avanços tecnológicos que possibilitem a implementação deste tipo de estratégia com geração de lucros para a empresa (CHURCHILL e PETER, 2005). As novas tecnologias permitem que a empresa torne seu composto de marketing mais individualizado, ou seja, torna possível oferecer um produto ou serviço único (ex: por meio de novas tecnologias produtivas), com um preço diferenciado (ex: com base num eventual histórico de compras do cliente), com uma propaganda diferenciada (ex: com base no perfil do consumidor) e oferecer esse produto ou serviço por canais diferenciados (ex: internet ou celular). 
A seguir, é apresentado o processo de segmentação, como proposto por Brandt (1966):
1) Definir o mercado

2) O processo de segmentação deve ser conduzido de forma especifica para cada mercado analisado.

3) Uma vez isolados, os segmentos devem ser suscetíveis a uma análise econômica para determinar sua viabilidade econômica.

4) A alocação de recursos para cada um dos segmentos escolhidos deve levar em consideração restrições estratégicas e táticas que podem existir no mercado.

Brandt (1966) sinaliza claramente para a necessidade de uma análise econômica e mercadológica para definir qual a estratégia mais adequada para a empresa. Essas considerações feitas pelo autor seriam posteriormente aproveitadas por outros autores, gerando uma série de itens que deveriam ser apreciados antes de se definir a escolha dos segmentos a serem atendidos.

Aaker e Day (1989, p. 568) definem algumas etapas que devem ser cumpridas para desenvolver uma pesquisa de segmentação:

1. Determinar o propósito e os objetivos da pesquisa

2. Identificar as perguntas do questionário para proporcionar as bases para definir e descrever os segmentos

3. Selecionar a base ou as bases sobre as quais se definirão os segmentos.

4. Descrever os segmentos selecionados como meta com base em outras variáveis ou descritores.

5. Desenvolver programas efetivos de marketing dirigidos aos segmentos fixados como alvo.

As etapas propostas por Aaker e Day (1989) ajudam a compreender os passos necessários para conduzir uma pesquisa de segmentação, mas peca ao não abordar a necessidade de conduzir o processo de forma periódica para identificar eventuais mudanças no perfil dos segmentos (BRANDT, 1966, DIBB, 1999). 


\subsubsection{Bases de segmentação de mercado}

Tendo definido o conceito de segmentação e apresentado os diferentes níveis de segmentação que podem ser realizados, torna-se necessário aprofundar as considerações sobre as bases de segmentação, ou seja, os critérios utilizados pela empresa para avaliar o grupo de consumidores em que pretende identificar os segmentos presentes. A escolha dessas bases pode ser apoiada no "conhecimento de mercado, nas tendências atuais das compras, na pesquisa de marketing e no bom senso (CHURCHILL e PETER, 2005, p.209).” As diferentes variáveis podem ser utilizadas de forma individual ou combinada (KOTLER E ARMSTRONG, 2005). Brandt (1966) diz que os critérios que poderiam ser utilizados durante o processo de segmentação não são exaustivos, mas sim representativos das possibilidades que existem para as empresas. Bom senso, uso combinado e não-exaustividade são os termos utilizados pelos autores supracitados e representam a idéia de que a escolha das variáveis de segmentação que serão utilizadas não é fácil, não é clara e deve contar com a experiência do profissional de marketing e do seu atual conhecimento do mercado para ser realizada de forma coerente.

De acordo com Aaker e Day (1989), a escolha das bases de segmentação deve estar profundamente relacionada aos programas de marketing da empresa, exigindo-se uma cuidadosa análise das bases a serem utilizadas à luz dos programas de marketing que podem estar associados a cada segmento. As considerações de Aaker e Day (1989) partem do pressuposto de que já existe algum tipo de interação entre a empresa e os mercados em estudo. Claramente, este não é o caso para todas as iniciativas de segmentação. Em algumas oportunidades, a empresa estará iniciando seus trabalhos junto a determinado público, sem ter nenhum programa de marketing direcionado para este grupo em particular. Percebe-se que em muitos casos a literatura de marketing falha em oferecer recomendações para àqueles que estão iniciando um negócio, apresentando os conceitos como se fossem direcionados para as grandes multinacionais, desprezando o pequeno empresário que está envolvido com o processo de criação de uma empresa.

Brandt (1966) traz uma das primeiras considerações da literatura de marketing sobre quais bases poderiam ser utilizadas: 
1) Dados demográficos, dados estatísticos sobre os consumidores: idade, renda, tamanho da família, sexo, educação e ocupação.

2) Traços comportamentais dos consumidores: classe social, status do ciclo de vida, origem étnica, hábitos de estilo de vida.

3) Dados sobre a performance dos consumidores: heavy users $^{8}$ versus light users $^{9}$, adotantes iniciais versus adotantes tardios etc.

4) Características psicológicas dos consumidores: personalidade, medidas sobre as atitudes etc.

Andreasen (1966) apresenta basicamente os mesmo critérios ou variáveis de segmentação apresentados por Brandt (1966), porém com uma nomenclatura e uma organização diferente: Geográfica (região, bairro), Econômica (renda, ocupação, classe social), Social (estado civil, crianças, ciclo de vida familiar) e Pessoal (idade, sexo, personalidade). Já Tynan e Drayton (1987) indicam que o mercado pode ser analisado com base em variáveis geográficas, demográficas, psicológicas, psicográficas e comportamentais.

Trazendo contribuições da academia brasileira, Richers (2000) apresenta no Quadro 2 uma visão mais abrangente dos critérios de segmentação que poderiam ser utilizados pelos profissionais de marketing ao conduzir pesquisas de segmentação. $\mathrm{O}$ autor expõe também uma série de exemplos fundamentados na realidade nacional, permitindo assim uma melhor compreensão da aplicabilidade de cada um dos critérios.

\footnotetext{
${ }^{8}$ Expressão em inglês que significa compradores costumazes (tradução do autor)

${ }^{9}$ Expressão em ingles que significa os compradores pouco costumazes (tradução do autor)
} 
Quadro 2 - Critérios de segmentação de mercado

\begin{tabular}{|c|c|}
\hline \multicolumn{2}{|l|}{ GEOGRÁFICA } \\
\hline Regiões & N, NE, SD, S, C; Metropolitana, Interior/Litorânea. \\
\hline Estados & RS, SC, PA, SP etc. \\
\hline Municípios & $\begin{array}{l}\text { Os } 5550+\text { municípios por potencial de compras relativo, tamanho, } \\
\text { localização etc. }\end{array}$ \\
\hline Densidade & $\%$ urbana, suburbana, rural. \\
\hline Cidades & Acima de $5 \mathrm{~m}$, entre 3 e $4,9 \mathrm{~m}$. \\
\hline Clima & Índice de precipitação. \\
\hline \multicolumn{2}{|l|}{ DEMOGRÁFICA } \\
\hline Tamanho da população & Abaixo (e acima) de idades-limites. \\
\hline Sexo & Masculino, feminino, unissex. \\
\hline Status Familiar & Sem vínculo, casado(a), separado(a), desquitado(a), viúvo(a). \\
\hline Número de dependentes & Filhos e outros dependentes. \\
\hline Raça & Branco, negro, mulato, índio. \\
\hline Ocupação/Profissão & Engenheiro, executivo, secretária, professor, operário etc. \\
\hline Nível de instrução & Analfabeto até instrução superior. \\
\hline \multicolumn{2}{|l|}{ SOCIAL } \\
\hline Classe Social & De A a E. \\
\hline Valores Sociais & $\begin{array}{l}\text { Grau de dependência, ética, religião, associação política, teatro, cinema, vídeo } \\
\text { etc. }\end{array}$ \\
\hline \multicolumn{2}{|l|}{ PSICOGRÁFICA } \\
\hline Personalidade & $\begin{array}{l}\text { Introvertido, extrovertido, autoconfiança, motivação e ambição, crenças, } \\
\text { valores, atitudes etc. }\end{array}$ \\
\hline Comportamento & $\begin{array}{l}\text { Escolha entre alternativas, compra/não compra, lealdade à marca, quantidade } \\
\text { de compra etc. }\end{array}$ \\
\hline Intensidade de compra & $\begin{array}{l}\text { Nunca comprou, usou a abandonou, comprador esporádico, irregular, } \\
\text { freqüente, viciado. }\end{array}$ \\
\hline Objetivos de compra & $\begin{array}{l}\text { Satisfazer necessidade, auto-estima, status social, auto-realização, família, } \\
\text { segurança etc. }\end{array}$ \\
\hline \multicolumn{2}{|l|}{ ESTILOS DE VIDA } \\
\hline Atividades & $\begin{array}{l}\text { Trabalho, turismo, ficar em casa, TV, música, clube, esportes, igreja, } \\
\text { shopping, ajudar etc. }\end{array}$ \\
\hline Opiniões & $\begin{array}{l}\text { Assuntos pessoais, sociais, comunitários, políticos, econômicos, financeiros, } \\
\text { educação, empresa, produtos, cultura, futuro etc. }\end{array}$ \\
\hline Interesses & $\begin{array}{l}\text { Família, casa, emprego, comunidade, hobby, drogas, comida, recreação + } \\
\text { divertimento, leitura etc. }\end{array}$ \\
\hline \multicolumn{2}{|c|}{ POR BENEFÍCIOS: (PARA CREME DENTAL, POR EXEMPLO) } \\
\hline Tipo de pessoa & Vaidosa, indiferente, hedonista, conservadora. \\
\hline Benefícios procurados & Brilho dos dentes, combate cáries, combate mau hálito, sabor, preço. \\
\hline
\end{tabular}

FONTE: Adaptado de RICHERS; 2000, p.69.

A escolha das variáveis de segmentação que serão utilizadas pela empresa está relacionada com o produto que ela oferece e o mercado onde irá atuar, sendo esta uma decisão que terá um impacto significativo nos resultados do processo (GREEN, 1977). A escolha das variáveis também está relacionada com a forma como será conduzida a pesquisa de segmentação.

Green (1977) oferece duas possibilidades para o processo: (a) segmentação a priori - a empresa seleciona uma variável que irá definir os segmentos, como, por exemplo, uma marca favorita; (b) segmentação post-hoc - os indivíduos são agrupados de acordo com um grupo de variáveis que são de interesse da empresa, como, por exemplo, comportamento de compra e 
atitudes. No primeiro caso a empresa irá detectar grupos de consumidores que gostam de marcas diferentes, sendo então necessária uma análise das características de cada um destes grupos para melhor compreender as razões que geram essa preferência. No segundo caso a empresa imagina que o consumidor do seu produto terá algumas características e busca identificar no mercado esses consumidores.

Wind (1978) critica severamente essa divisão proposta por Green (1977), por acreditar que os trabalhos desenvolvidos pela academia de marketing apresentam importantes avanços teóricos e metodológicos que não foram aproveitados por Green (1977). Hooley e Saunders (1996) dão exemplos de casos onde o processo de segmentação a priori tem tido pouco sucesso, principalmente quando o processo foca em variáveis demográficas ou sócio-gráficas, mas, ao mesmo tempo, também apresentam casos onde este tipo de estratégia é adequada.

De acordo com os autores, cabe no momento da decisão uma avaliação por parte da empresa para verificar se o seu mercado pode ser efetivamente segmentado com base nesse tipo de variável. De qualquer forma, concluem Hooley e Saunders (1996, p.224) "a evidência parece mostrar que as características demográficas, por si só, são incapazes de distinguir as diferenças sutis em mercados que não são explicadas por diferenças fisiológicas entre os seres humanos".

Wind (1978) apresenta, com base nos estado atual da literatura na época, um modelo do processo de segmentação que responde às críticas por ele levantadas. 
Quadro 3 - O Processo de Segmentação

I. Definição do problema

a. Requerimentos da administração da empresa

b. Segmentação pontual ou continua

c. Modelo de segmentação

i. Seleção das variáveis do modelo

ii. Relação entre abordagens tradicionais (ad hoc e a priori) versus design de segmentação mais flexíveis.

II. Design da Pesquisa
a. Unidade de análise
b. Definições operacionais
c. Design da amostragem
d. Confiabilidade dos dados
e. Estabilidade do segmento
f. Homogeneidade do segmento
g. Capacidade de segmentar o mercado
h. Validação
i. Considerações de custo

III. Coleta dos dados

a. Fontes primários versus fontes secundárias

b. Procedimentos convencionais versus novos procedimentos

IV. Análise dos dados

a. Para determinar os segmentos: classificação

b. Para estabelecer o perfil dos segmentos: discriminação

c. Para classificação e discriminação simultânea

V. Interpretação dos dados e implementação dos resultados

a. Determinação do número de segmentos e seleção dos segmentos-alvo

b. Traduzir os resultados da segmentação em estratégia FONTE: Adaptado de WIND; 1978, p.318.

Os esclarecimentos de Tolley (1975) acrescentam à obra de Wind (1978) no sentido de que a empresa deve realizar pesquisas de segmentação que incluam um número considerável de variáveis, abordando usuários e não usuários de determinado produto. As variáveis que apresentarem resultados diferentes entre o grupo de usuários e não usuários podem ser utilizadas para compreender melhor o mercado em estudo.

Duas décadas depois da publicação dos estudos de Wind (1978) e Tolley (1975), Hooley e Saunders (1996) e McDonald e Dunbar (1998) consideraram que deve existir um processo de segmentação de primeira ordem e outro de segunda ordem. Como base de segmentação de primeira ordem a empresa poderia utilizar como variável de agregação a busca pelos mesmos benefícios no uso do produto ou serviço. A partir daí a empresa deveria utilizar outras variáveis para "melhorar a capacidade da empresa em adequar o mix de marketing num segmento de primeira ordem" (HOOLEY e SAUNDERS, 1996, p.213).

Nesta mesma toada, Aaker e Day (1989) também são partidários do uso de dois grupos de variáveis, sendo que o primeiro grupo de variáveis serviria para escolher os segmentos e o segundo grupo para obter uma melhor compreensão das características destes segmentos. 
Lambin (2000) também incentiva o uso da segmentação em duas etapas, porém ele aborda a questão de forma diferenciada do que foi apresentado anteriomente. Para o autor, o primeiro passo que a empresa deve tomar é selecionar o seu mercado de atuação. Lambin (2000) denominou essa etapa de macro-segmentação. A etapa seguinte foi denominada de microsegmentação, a qual constitui a realização do processo de segmentação do mercado escolhido. A partir das considerações de Aaker e Day (1989), Lambin (2000), Hooley e Saunders (1996) e McDonald e Dunbar (1998) é possível compreender o processo de segmentação como sendo constituído por três etapas, apresentadas na Ilustração 5:

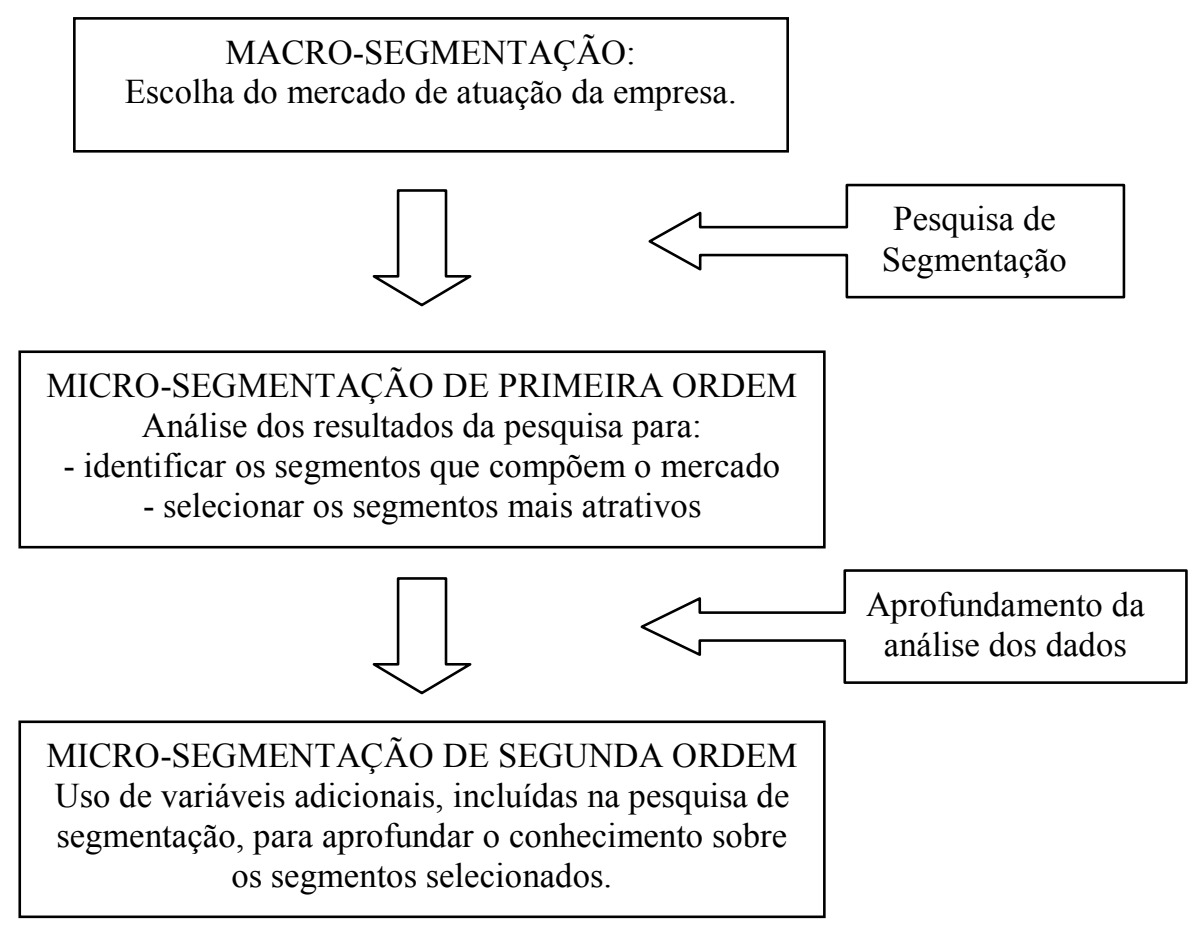

Ilustração 5 - Processo de macro e micro-segmentação.

Fonte: elaborado pelo autor com base em AAKER e DAY; 1989, LAMBIN; 2000, HOOLEY e SAUNDERS; 1996 e MCDONALD e DUNBAR; 1998.

A partir das considerações dos autores (HOOLEY e SAUNDERS, 1996; LAMBIN, 2000; AAKER e DAY, 1989), percebe-se que existe uma determinada limitação no número de variáveis que são adequadas para a seleção de segmentos-alvo. Desta forma, existem variáveis que podem ser incorporadas na pesquisa, mas que não necessariamente servirão como variáveis de segmentação, mas sim como variáveis para compreender de forma mais profunda as características do segmento escolhido. 
A partir destas considerações é possível entender que a cada momento em que a empresa agrega mais variáveis no seu processo de segmentação, mais próxima ela chega de identificar segmentos mais coesos, mas que esse uso de variáveis tem um determinado limite ótimo. A idéia de ter dois tipos de variáveis é apresentada no Quadro 3, mais precisamente no ponto IV. Wind (1978) coloca que durante a análise dos dados deve haver uma preocupação em determinar os segmentos e também estabelecer o perfil destes segmentos, sendo esta última uma potencial variável de segunda ordem.

Ao fazer uma pesquisa de segmentação a empresa deve coletar uma série de dados que terão dois objetivos principais: (a) Identificar os segmentos que compõe o mercado; e (b) Definir o perfil dos segmentos resultantes. Deve ficar claro que nem todas as variáveis de segmentação serão utilizadas nos dois momentos (HOOLEY e SAUNDERS, 1996). Além disso, também cabe colocar que os diversos autores que propõem uma série de bases de segmentação o fazem como forma de sugestão, embora ela não seja definitiva ou exaustiva (AAKER e DAY, 1989; BRANDT, 1966).

\subsubsection{Modelos de segmentação proprietários}

Algumas empresas desenvolveram modelos de segmentação proprietários que se tornaram bastante utilizados no mercado, como por exemplo, o VALS2 (Valores, Atitudes e Estilos de Vida $^{10}$ ) e o PRIZM (Índice de Classificação Potencial por Mercados Localizados ${ }^{11}$ ) (CHURCHILL e PETER, 2005). O modelo VALS2 (vide Ilustração 6) é o desenvolvimento de outro modelo anteriormente oferecido denominado VALS e está focado no uso de variáveis psicográficas, caracterizando uma série de grupos que compõem a sociedade norteamericana.

\footnotetext{
${ }^{10}$ Do original Values, Atitudes and Life-Styles

${ }^{11}$ Do original Potential Ranking Index by Zip Markets
} 


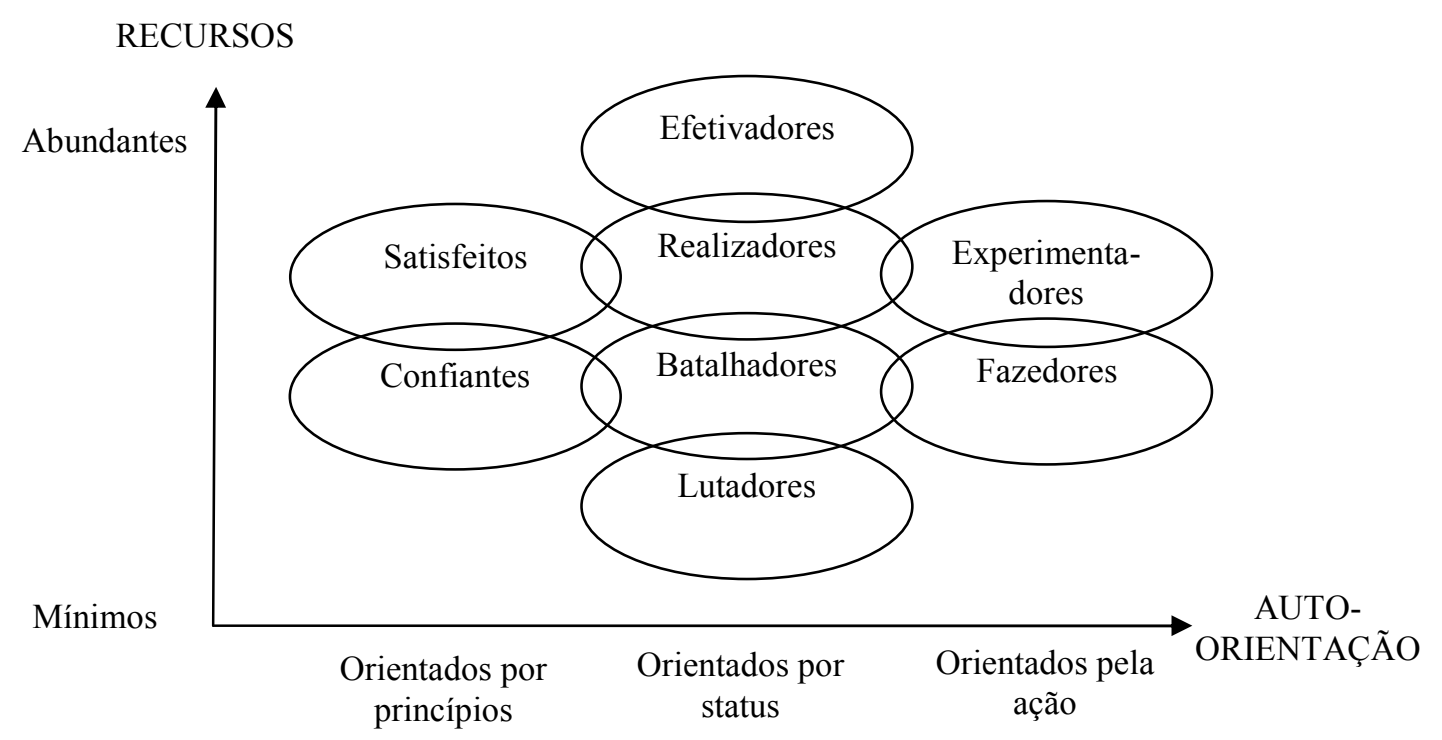

Ilustração 6 - Categorias de estilo de vida do VALS 2

FONTE: CHURCHILL e PETER; 2005. p.215.

Os modelos desenvolvidos pela SRI (VALS e VALS 2) têm sido amplamente abordados pela literatura de marketing, principalmente em livros texto como Schiffman e Kanuk (2000), Churchill e Peter (2005), Blackwell et al. (2005) e Mowen e Minor (2003). Cabe colocar que o modelo foi desenvolvido por uma empresa de pesquisa e consultoria (SRI International) e, em função disso, não se tem acesso ao método empregado para a análise dos dados, aferição da confiabilidade da pesquisa, instrumento de coleta de dados, entre outros itens que seriam fundamentais para assertar a validade do que é oferecido por meio de consultoria (MOWEN e MINOR, 2003). Para dar suporte às considerações anteriores cabe trazer as palavras de Campomar e Gil (2006, p.11), que apesar de direcionadas para o modelo VALS original também cabem aqui:

A utilização de VALS em outros países que não os Estados Unidos não é fácil, posto que o instrumento leva em consideração os valores individuais, que são reflexo dos valores de uma sociedade. Além disso, como é de propriedade particular não permite que acadêmicos estudem sua validade.

Somam-se a essas considerações, as colocações de Lambin (2000) com relação a modelos de segmentação que utilizam variáveis relacionadas a estilo de vida. De acordo com o autor, são inúmeras as críticas feitas a esses modelos. Ele traz como exemplo dois modelos desenvolvidos na França (CCA e Cofremca), que apesar de analisar o mesmo país, chegaram a resultados discrepantes. 
Desta forma, torna-se indesejado fazer maiores considerações sobre o modelo, cabendo apenas salientar a idéia da sobreposição dos segmentos. É ilusão imaginar que os segmentos não se sobrepõem uns aos outros, devendo haver uma preocupação da empresa em lidar com aqueles consumidores que tem preferências diferenciadas em função das suas características.

Outro modelo que também é amplamente abordado pelos livros texto da área de marketing é o PRIZM (CHURCHILL e PETER, 2005; KOTLER e ARMSTRONG, 2005; SCHIFFMAN e KANUK, 2000), sendo este desenvolvido pela empresa Claritas Inc., o qual

[...] inclui diversas variáveis diferentes baseadas na geodemografia. Que liga dados demográficos e geográficos de uma cidade, bairro ou comunidade (vizinhança local). As comunidades são classificadas com base em demografia detalhada para que o produto, mídia e preferências de estilo de vida de cada aglomeração possam ser obtidos para criar perfis das pessoas que moram nessas localizações. (CHURCHILL e PETER, 2005, p.217-218).

A lógica do modelo PRIZM está fundamentada na idéia de que pessoas que moram juntas, em regiões próximas, devem apresentar algum nível de similaridades nas bases de segmentação consideradas e, por causa disso, também devem apresentar desejos e necessidades semelhantes, compondo então grupos de consumidores que podem ser considerados um segmento (CHURCHILL e PETER, 2005). As mesmas críticas feitas ao modelo da empresa SRI podem ser estendidas ao PRIZM, ou seja, o pouco acesso às informações referentes à elaboração do modelo e a coleta de dados não permite uma avaliação mais aprofundada da sua qualidade.

\subsubsection{Efetividade do processo de segmentação de mercado}

Após conduzir uma pesquisa de segmentação, fundamentada nas bases de segmentação escolhidas pela empresa, chega-se ao momento em que os dados estão disponíveis para análise. Beane e Ennis (1987) exploram a literatura referente ao conceito de segmentação e identificam as técnicas estatísticas de analise de dados mais utilizadas: AID (Automatic Interaction Detector ou Identificador Automático de Interações), MAID (versão multivariada do AID), Análise Canônica, Análise Fatorial, Análise de Cluster, Análise de Regressão, Análise Discriminante, Escalonamento Multidimensional, Segmentação Componencial. Os autores apresentam as diferentes técnicas que podem ser utilizadas e salientam que existem múltiplas formas de segmentar um mercado e, por este motivo, o pesquisador ou profissional de marketing deve estar imbuído da curiosidade de investigar todas as formas de análise que possam trazer resultados promissores. 
O resultado dessas análises estatísticas é um determinado número de segmentos identificados. De posse dessas informações, a empresa deve proceder um cuidadoso exame, buscando identificar os segmentos que lhe são de algum interesse. A avaliação quanto à efetividade do processo de segmentação e a atratividade dos segmentos pode ser baseada em cinco critérios básicos (KOTLER e KELLER, 2006, p.257-258):

1. Mensuráveis. O tamanho, o poder de compra e as características dos segmentos devem ser passíveis de mensuração.

2. Substanciais. Os segmentos devem ser grandes e rentáveis o suficiente para serem atendidos. Um segmento deve ter o maior grupo homogêneo possível e um programa de marketing bem desenvolvido.

3. Acessíveis. Deve ser efetivamente possível alcançar e atender ao segmento.

4. Diferenciáveis. Os segmentos são conceitualmente distintos e respondem de maneira diferente a cada elemento e programa do mix de marketing.

5. Acionáveis. Deve ser possível desenvolver programas efetivos para atrair e atender aos segmentos.

Dibb (1999) tece críticas a ampla aceitação dos critérios propostos por Kotler (1984), apresentados com base na obra de Kotler e Keller (2006). De acordo com Dibb (1999), essa lista de critérios não é abrangente o suficiente para gerar uma ferramenta que possa efetivamente ser utilizada pelas empresas. Com base nessas considerações, a autora desenvolve um modelo mais compreensivo (vide Ilustração 7), o qual pretende facilitar a compreensão e a aplicabilidade do conceito por parte das empresas. Neste modelo, a autora coloca a importância de alguns fatores críticos para o sucesso do processo de segmentação. Entre as sugestões apresentadas, salienta-se a importância do envolvimento da alta administração da empresa e de uma atenção especial para mudanças que possam ocorrer no mercado ao longo do processo de segmentação. 
FATORES DE SUCESSO DA SEGMENTAÇÃO:

Planejamento bem desenhado, comprometimento/envolvimento da alta administração, escolha das bases de segmentação, resposta rápida as mudanças do mercado, pensamento criativo, objetivos claros, atenção a implementação

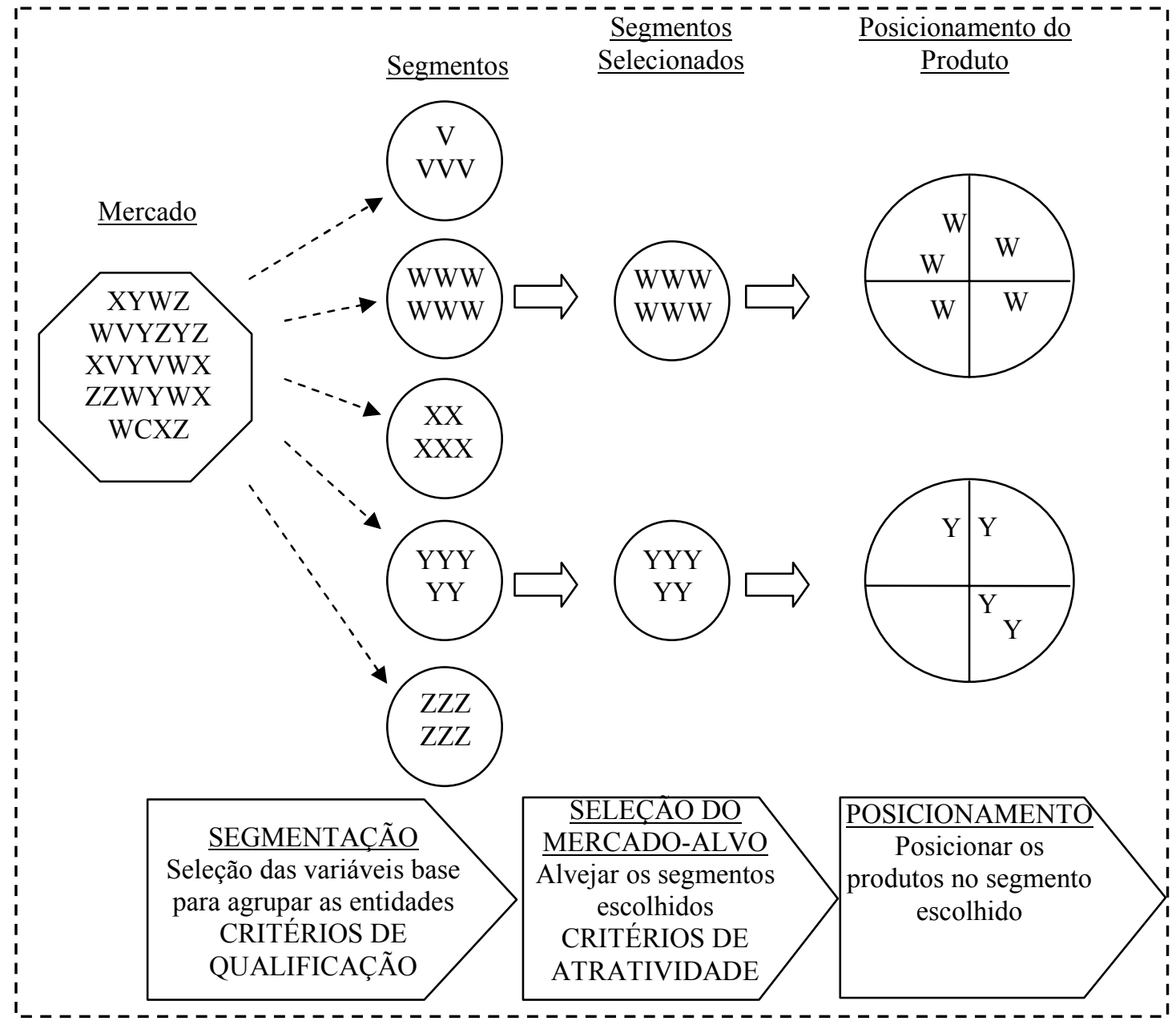

FATORES DE SUCESSO DA SEGMENTACÃO:

Planejamento bem desenhado, comprometimento/envolvimento da alta administração, escolha das bases de segmentação, resposta rápida as mudanças do mercado, pensamento criativo, objetivos claros, atenção a implementação

Ilustração 7 - O papel dos fatores de sucesso da segmentação FONTE: DIBB; 1999, p.124.

Já Hooley e Saunders (1996, p.52) trazem uma visão mais ampla na análise da atratividade do mercado. Para os autores, é necessário compreender a atratividade do mercado onde a empresa irá competir para atender os clientes selecionados como alvo. Percebe-se aqui uma diferença entre os conceitos colocados anteriormente, pois existe uma diferença entre analisar o mercado de acordo com a atratividade dos consumidores que o compõem e agregar tanto a questão da competitividade deste mercado quanto às barreiras para entrada e saída. De acordo com os pesquisadores, é necessário analisar as seguintes condições para verificar se o mercado é atrativo: 
- O mercado é grande.

- O mercado está crescendo.

- As margens de contribuição são grandes.

- A pressão da rivalidade da concorrência é pequena.

- Há altas barreiras de entrada e baixas barreiras de saída.

- O mercado não é vulnerável a eventos incontroláveis.

As considerações de Hooley e Saunders (1996) estão amplamente fundamentadas nos pensamentos de Porter (1986), apresentados na Ilustração 8.

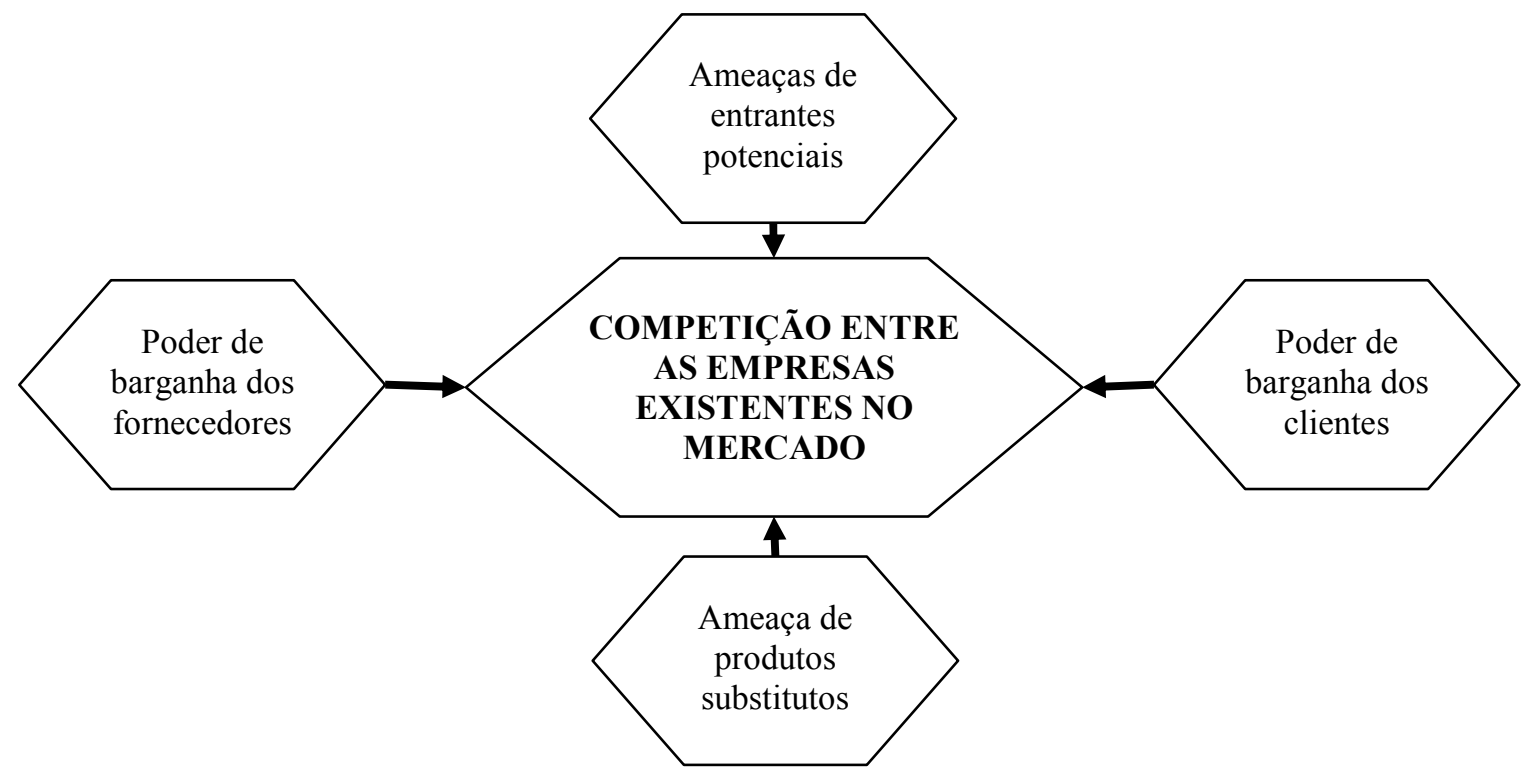

Ilustração 8 - Modelo de Porter para análise do mercado.

FONTE: Adaptado de PORTER; 1986.

Importantes também são as contribuições de Firat e Shultz (1997), que adotam uma perspectiva pós-modernista para ressaltar a necessidade de uma maior atenção, por parte dos acadêmicos e profissionais de marketing, a um mercado caracterizado pela instabilidade, imprevisibilidade e por uma dinâmica mais acentuada.

Ainda neste contexto, diversos autores apontaram algumas limitações para o uso da técnica. McDonald e Dunbar (1998) enxergam a segmentação de mercado como um conceito simples de ser entendido, mas muito difícil de ser implementado na prática. Danneels (1995) destaca a pouca quantidade de estudos que abordam a aplicação prática dos conceitos de segmentação. 
Dibb (1999) também coloca em questão a falta de trabalhos que dêem um direcionamento prático para empresas que estão desenvolvendo estudos de segmentação.

Percebe-se ai que tanto Danneels (1995) quanto Dibb (1999) estão preocupados com a grande discrepância entre o que dizem os livros-texto e a prática. De forma geral, a partir dos autores apresentados, percebe-se que existe uma grande preocupação da academia em trazer o conceito de segmentação para a realidade empresarial.

Danneels (1995) visualiza como causa deste fenômeno o direcionamento da teoria para grandes organizações, que teriam os recursos necessários para realizar amplas pesquisas de segmentação. Isso seria explicado pelo distanciamento existente entre os administradores das grandes organizações e seus clientes, ao passo que as empresas que não fazem parte do grupo das grandes organizações têm como característica inerente ao seu tamanho a obrigatória proximidade dos administradores com os seus clientes, facilitando a existência de um grande entendimento das necessidades dos clientes, mesmo sem a realização de uma pesquisa de segmentação.

Outra questão que merece consideração com relação à efetividade do processo de segmentação relaciona-se com sua periodicidade. De acordo com McDonald e Dunbar (1998), o processo deve ser revisado periodicamente para identificar potenciais mudanças nas preferências dos consumidores. Questões como essas, entre outras, como acirramento da concorrência, influências culturais variadas e mudanças de comportamento, podem fazer com que os desejos e necessidades do grupo de consumidores que a empresa atende mudem, tornando imperativa a realização de um novo processo de segmentação para identificar essas variações.

Finalizando esta etapa da revisão bibliográfica, cabe apresentar a análise que Dibb (2005, p16-17) conduziu para identificar quais são as principais barreiras e problemas que uma empresa enfrenta ao colocar em prática o processo de segmentação. As colocações da autora sinalizam para uma série de problemas relacionados à infra-estrutura, cultura e processos. Cabe então à empresa avaliar as colocações da autora e verificar como elas se enquadram em sua realidade, implementando mudanças que possibilitem a correta implementação do processo de segmentação. 
McDonald e Dunbar (1998, p.273) também entendem que existem alguns aspectos críticos para a implementação do marketing de segmentos:

O suporte do presidente da empresa e da alta administração.

Um sentimento de propriedade das conclusões por parte das unidades operacionais chave, gerada por seu envolvimento no processo,

Um processo de planejamento de marketing institucionalizado que pode tomar os resultados do processo de segmentação e desenvolver-lo em um plano estratégico tri-anual, ou em um programa de marketing anual.

As contribuições de McDonald e Dunbar (1998) focam na questão do envolvimento das diferentes esferas da companhia e no correto uso dos resultados, sob a forma de um processo de planejamento institucionalizado. As considerações de Dibb (2005), por sua vez, são mais compreensivas, permitindo um entendimento mais aprofundado das razões que impedem a correta implementação de um processo de segmentação.

De qualquer forma, fica clara a necessidade da criação de uma estrutura que consiga gerenciar o processo como um todo, abrangendo desde a alocação de recursos (humanos, físicos e de conhecimento), passando pelo o apoio da alta administração da empresa e terminando na transformação dos resultados encontrados na base do processo de planejamento da empresa. Somente assim, as empresas terão a chance de obter as vantagens competitivas decorrentes do processo. 
Quadro 4 - Barreiras ao processo de segmentação de mercado

\begin{tabular}{|c|c|c|c|c|}
\hline \multirow{4}{*}{ Infraestrutura } & \multicolumn{2}{|l|}{$H A R D$} & \multicolumn{2}{|r|}{ SOFT } \\
\hline & Dados & $\begin{array}{l}\text {-Poucos dados disponíveis } \\
\text {-Inexistência de um sistema de informações de marketing }\end{array}$ & Cultura & $\begin{array}{l}\text {-Inexistência de uma cultura de } \\
\text { coleta de dados } \\
\text {-Falta do foco no consumidor }\end{array}$ \\
\hline & Expertise & $\begin{array}{l}\text {-Falta de um conhecimento geral sobre marketing } \\
\text {-Função de marketing pequena ou inexistente } \\
\text {-Baixo conhecimento sobre segmentação }\end{array}$ & Estrutura & $\begin{array}{l}\text {-Envolvimento inadequado da alta } \\
\text { administração ou interferência nas } \\
\text { iniciativas de marketing }\end{array}$ \\
\hline & $\begin{array}{l}\text { Alocação } \\
\text { de recursos }\end{array}$ & $\begin{array}{l}\text {-Inexistência da disponibilidade de recursos financeiros ou humanos para a } \\
\text { coleta de dados e/ou análise dos dados } \\
\text {-Poucos recursos destinados ao pensamento estratégico }\end{array}$ & & $\begin{array}{l}\text {-Canais fracos de comunicação } \\
\text { entre/intra áreas funcionais }\end{array}$ \\
\hline \multirow{3}{*}{ Processo } & Dados & $\begin{array}{l}\text {-Pouca disponibilidade de dados para identificação das bases de } \\
\text { segmentação } \\
\text {-Capacidade de software inadequada }\end{array}$ & Cultura & $\begin{array}{l}\text {-Pouco comprometimento com a } \\
\text { disseminação de dados ou idéias } \\
\text {-Adesão ou comprometimento } \\
\text { interfuncional inadequado } \\
\text {-Liderança pobre }\end{array}$ \\
\hline & Expertise & $\begin{array}{l}\text {-Falta de pessoal qualificado de marketing } \\
\text {-Pobre entendimento ou mal uso do processo básico de segmentação } \\
\text {-Pouca apreciação ou adequação ao planejamento estratégico corporativo } \\
\text {-Baixo nível de capacidades analíticas de marketing }\end{array}$ & \multirow[t]{2}{*}{ Estrutura } & \multirow{2}{*}{$\begin{array}{l}\text {-Inadequado envolvimento ou } \\
\text { comprometimento da alta } \\
\text { administração às iniciativas de } \\
\text { marketing } \\
\text {-Canais fracos de comunicação } \\
\text { intra/entre áreas funcionais }\end{array}$} \\
\hline & $\begin{array}{l}\text { Alocação } \\
\text { de recursos }\end{array}$ & $\begin{array}{l}\text {-Orçamento inadequado para realizar a coleta de dados ou análise necessária } \\
\text {-Ausência de pessoal devotado ao processo de segmentação } \\
\text {-Tempo insuficiente devotado ao processo }\end{array}$ & & \\
\hline \multirow{3}{*}{ Implementação } & Dados & -Pouca disponibilidade de dados para mensurar a performance & Cultura & $\begin{array}{l}\text {-Comunicação interna/externa não } \\
\text { efetiva da solução de segmentação } \\
\text {-Foco no produto ao invés do foco } \\
\text { no cliente no sistema de distribuição }\end{array}$ \\
\hline & Expertise & $\begin{array}{l}\text {-Convicção insuficiente ou habilidades para operacionalizar o esquema de } \\
\text { segmentação } \\
\text {-Pouca aderência entre os programas táticos de marketing e a solução de } \\
\text { segmentação } \\
\text {-Falta de conhecimento no planejamento da implementação }\end{array}$ & \multirow[t]{2}{*}{ Estrutura } & \multirow[t]{2}{*}{$\begin{array}{lcc}\text {-Inadequado } & \text { envolvimento } & \text { da } \\
\text { administração } & \text { sênior } & \text { na } \\
\text { implementação da segmentação } & \\
\text {-Falta de clareza na demarcação da } \\
\text { responsabilidade } & \text { pela } \\
\text { implementação } & \end{array}$} \\
\hline & $\begin{array}{l}\text { Alocação } \\
\text { de recursos }\end{array}$ & $\begin{array}{l}\text {-Inadequação ou pouco alinhamento entre a criação do orçamento/alocação } \\
\text { de recursos para a implementação } \\
\text {-Tempo insuficiente destinado a implementação da solução de segmentação }\end{array}$ & & \\
\hline
\end{tabular}

FONTE: DIBB; 2005, p.16-17. 


\subsection{Segmentação e o mercado infantil}

Esta etapa do trabalho busca apresentar a literatura que trabalha aspectos relevantes para o processo de segmentação de uma empresa focada no mercado infantil. Após vasta exploração bibliográfica, identificou-se que a literatura especializada no consumidor infantil aborda conceitos relacionados à variável de segmentação idade, mesmo que de forma secundária, e à pesquisa com este grupo de consumidores. Outros aspectos do processo de segmentação de mercado não são abordados e representam uma clara lacuna no conhecimento. Desta forma, esta fase do trabalho abordará as teorias que ajudam a compreender a preponderância da variável idade como base de segmentação e as considerações relevantes da literatura referentes a pesquisas com crianças.

\subsubsection{Variáveis de segmentação - idade}

A grande maioria dos autores da área de comportamento do consumidor infantil tratam a questão da segmentação sob o ponto de vista demográfico, usando a questão da idade como uma proxy das capacidades da criança em se relacionar com a empresa e assumir seu papel como consumidora. Isso ocorre porque a criança não nasce com todas as suas capacidades como consumidora consolidadas. A criança vai se tornar uma consumidora mais completa conforme ela se desenvolver socialmente, psicologicamente e fisiologicamente. Esse processo é apresentado na Ilustração 9, onde a aquisição de competências é relacionada à idade da criança. 


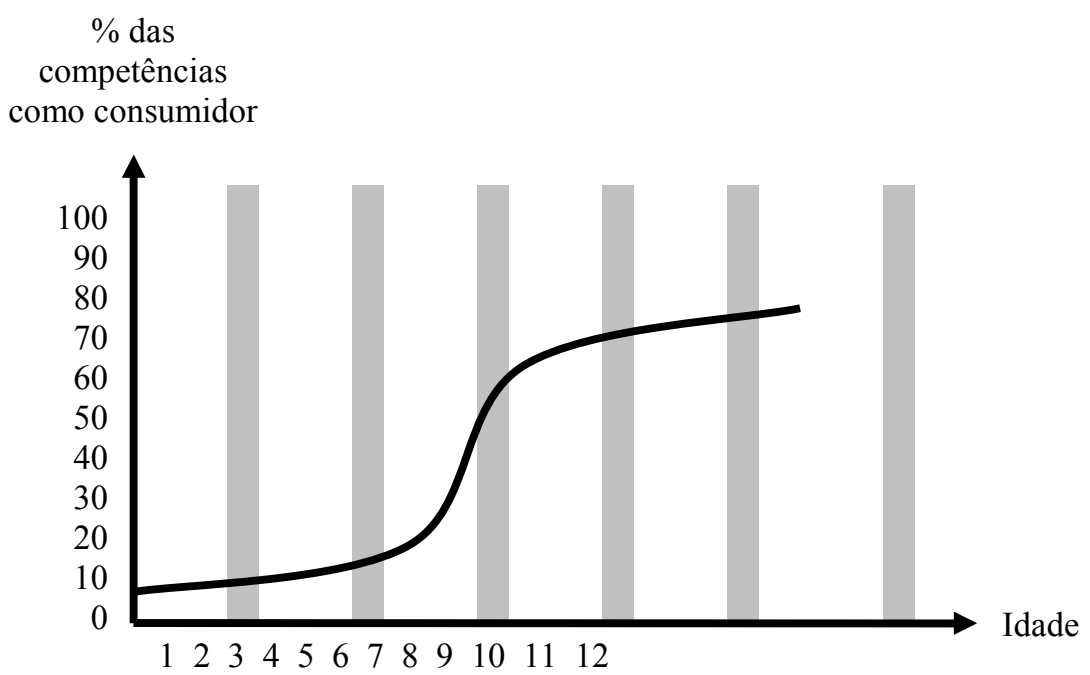

\section{Ilustração 9 - Desenvolvimento das competências como consumidor durante a infância FONTE: MCNEAL; 1999, p.37.}

É curioso notar que num primeiro momento McNeal (1969) tenta definir o mercado infantil como aquele composto por crianças entre 5 e 13 anos, como pode ser verificado no trecho a seguir:

Sempre existiu no marketing moderno a percepção da influência da criança nas compras do domicílio. [...] o novo mercado infantil, referenciado aqui não significa as crianças que influenciam as compras dos pais. Nem significa itens comprados para o domicílio, como leite e pão. E também não inclui os bilhões de dólares gastos pelos pais com as crianças. $\mathrm{O}$ termo mercado infantil, conforme empregado aqui, refere-se ao grupo composto por crianças entre 5 e 13 anos [...] que compram produtos e serviços para seu uso pessoal e satisfação. (MCNEAL, 1969, p. 16).

Posteriormente, o mesmo autor passa a aceitar que o termo deveria ser um pouco mais abrangente para poder abarcar todas as influências que a criança exerce perante aqueles que estão próximos e todas as compras por elas realizadas (MCNEAL, 1992; 1999). Com relação à identificação etária do mercado infantil, McNeal $(1992 ; 1999)$ coloca estabelece o consumidor como tendo entre 4 e 12 anos. Esses números representam uma pequena mudança em relação a 1969.

Siegel et al. (2001) cunham a palavra tween ${ }^{12}$ para designar crianças com idade compreendida entre 8 e 12 anos. Apesar de colocarem que essa época do desenvolvimento da criança não está diretamente relacionada à idade da criança, mas sim ao seu desenvolvimento psicológico, os autores consideram que os limites 8 e 12 são corretos para estabelecer algum tipo de separação

\footnotetext{
${ }^{12} \mathrm{O}$ termo surge do termo inglês in between, ou seja, estar entre alguma coisa. No caso aqui colocado é a criança que se encontra entre a infância e a adolescência.
} 
para crianças no decorrer do seu processo de desenvolvimento. Os autores salientam que as estratégias e políticas de marketing sugeridas por eles podem não ser as mais adequadas quando a empresa direciona seus esforços de marketing para os extremos da faixa etária. Outros autores, como Azzarone (2003), adotam estrutura semelhante. Já Lindstrom (2003a; 2003b) expande o limite etário dos tweens até aproximadamente 14 anos.

Montigneaux (2003, p. 27-63) discorre sobre o desenvolvimento da criança e a formação da sua visão de mundo trabalhando segmentos de idade que vão desde o nascimento da criança até os seus 12 anos. Para o autor, esse mercado deve ser dividido em três faixas de idade para ser mais bem compreendido. As faixas sugeridas pelo autor são: (a) de 0 até 2 ou 3 anos; (b) de 2 ou 3 anos até 6 ou 7 anos; (c) de 7 até 12 anos. Acuff e Reihner (1997) utilizam uma estrutura similar a Montigneaux (2003), indicando as seguintes faixas etárias:

- Estágio de dependência/exploratório - de 0 a 2 anos;

- Estágio da emergência da autonomia - de 3 a 7 anos;

- Estágio das regras e dos papéis - de 8 a 12 anos;

- Estágio da adolescência recente - de 13 a 15 anos; e

- Estágio da adolescência tardia - de 16 a 19 anos.

Vecchio (2002) também trabalha o segmento infantil abordando faixas com idade de até 12 anos, mas, em alguns momentos, apresenta dados demográficos em que as faixas se estendem até os 17 anos.

Apesar dos autores aqui apresentados não serem explícitos nas suas considerações sobre as razões que os fizeram escolher as faixas etárias apresentadas, é possível buscar a raiz de tais colocações nas teorias de Piaget. Ao criar o arcabouço das teorias do desenvolvimento cognitivo, Piaget (1959) estabeleceu alguns limiares de idade que separam crianças com diferentes capacidades 
cognitivas. Ao tentar segmentar o mercado infantil a empresa deve estar atenta para esses limiares, pois a capacidade de compreensão da criança muda de forma significativa entre um período e outro. Dessa forma, os conceitos referentes ao processo de desenvolvimento cognitivo servem como pano de fundo para compreender o uso da variável idade como base para a segmentação de mercado.

O processo de desenvolvimento cognitivo da criança é acompanhado pelo processo de socialização, o qual envolve os meios pelos quais os indivíduos adquirem as capacidades, conhecimentos e atitudes necessárias para o seu correto funcionamento em interações sociais. Entre as funções desempenhadas por indivíduos na sociedade moderna, dá-se destaque para o indivíduo como consumidor. Destarte, a socialização do indivíduo envolve o processo de aprendizagem da criança como consumidora (WARD, 1974).

Portanto, se faz necessário compreender analisar a base de segmentação idade sob o enfoque do desenvolvimento cognitivo e do processo de socialização para compreender de forma mais completa a utilidade desta variável para os estudiosos e profissionais de marketing.

\subsubsection{Variáveis de segmentação - idade - desenvolvimento cognitivo}

O trabalho mais reconhecido em se tratando de desenvolvimento cognitivo da criança é a teoria do desenvolvimento cognitivo de Piaget (1959). O francês propõe três estágios básicos no desenvolvimento cognitivo: o sensório-motor, o de inteligência representativa (subdividido em pré-operacional e concreto-operacional) e o operacional formal. No Quadro 5 são apresentadas as etapas do desenvolvimento cognitivo da criança de acordo com as teorias de Piaget. Posteriormente, será realizado um esforço teórico para aprofundar o entendimento de cada uma das etapas. 
Quadro 5. Os quatro estágios do desenvolvimento cognitivo segundo Piaget

\begin{tabular}{|l|l|l|}
\hline \multicolumn{1}{|c|}{ Estágio } & \multicolumn{1}{|c|}{ Idade Aproximada } & \multicolumn{1}{c|}{ Características } \\
\hline Sensório Motor & $\begin{array}{l}\text { Do nascimento aos } 2 \\
\text { anos }\end{array}$ & $\begin{array}{l}\text { O conhecimento do que o bebê tem mundo está baseado nos } \\
\text { sentidos e nas habilidades motoras. Ao final do período, ele } \\
\text { emprega representações mentais. }\end{array}$ \\
\hline $\begin{array}{l}\text { Pensamento pré- } \\
\text { operatório }\end{array}$ & Dos 2 aos 6 anos & $\begin{array}{l}\text { A criança aprende a utilizar símbolos, como palavras e números, } \\
\text { para representar aspectos do mundo, mas se relaciona com ele } \\
\text { apenas por meio de sua própria perspectiva. }\end{array}$ \\
\hline $\begin{array}{l}\text { Pensamento } \\
\text { operatório-concreto }\end{array}$ & Dos 7 aos 11 anos & $\begin{array}{l}\text { A criança entende e aplica operações lógicas a experiências desde } \\
\text { que estejam centradas no aqui e agora. }\end{array}$ \\
\hline $\begin{array}{l}\text { Pensamento } \\
\text { operatório-formal }\end{array}$ & $\begin{array}{l}\text { Adolescência em } \\
\text { diante }\end{array}$ & $\begin{array}{l}\text { O adolescente ou adulto pensa abstratamente, especula sobre } \\
\text { situações hipotéticas e raciocina dedutivamente sobre o possível. }\end{array}$ \\
\hline
\end{tabular}

FONTE: KAIL; 2004, p. 13.

O primeiro período avança até aproximadamente 1,5 a 2 anos e passa primeiramente por uma fase de centralização do próprio corpo seguida por uma de objetivação e especialização de esquemas da inteligência prática. "Durante os primeiros 24 meses, os bebês entendem suas experiências pela visão, tato, paladar, olfato e manipulação. Em outras palavras, elas usam os sistemas sensorial e motor" (DAVIDOFF, 2001, p.438). O cientista desenvolve seu raciocínio, indicando que durante essa fase da vida do bebê, ele estará aprendendo que as visões, os sons, os toques, gostos e cheiros podem trazer informações sobre um mesmo objeto. É interessante notar que para crianças dessa faixa etária o fato de "estar fora do campo de visão" é equivalente a "não existir".

A criança desenvolve até os dois anos de idade o pensamento simbólico, mas ainda esta mais preocupada com as propriedades perceptíveis dos estímulos (PIAGET, 1959). Com o passar do tempo, a criança começa a perceber que existe a chamada noção de permanência do objeto. Além disso, completa o autor que durante este período da vida do bebê também se desenvolve a capacidade de imitar respostas novas e complexas mesmo quando o modelo está ausente. Dessa forma, a criança pode mostrar emoções e comportamentos próprios quando, na verdade, está apenas imitando algo que viu anteriormente (DAVIDOFF, 2001).

Montigneaux corrobora com a teoria de Piaget afirmando que os primeiros anos de vida de uma criança constituem um período dominado "pelo seu egocentrismo, isto é, a impossibilidade de considerar e levar em conta o mundo lá fora, para além dela própria, e de uma maneira objetiva" (MONTIGNEAUX, 2003, p. 34). Assim, crianças dessa idade não diferenciam produtos adequadamente, com menos intensidade ainda conseguem distinguir marcas e muito raramente 
comunicar seus desejos, primeiro por incapacidade lingüística e segundo por desinteresse na interação com outros indivíduos.

O segundo período de desenvolvimento cognitivo prossegue até os 7 ou 8 anos e envolve a evolução das funções direcionais, das identidades qualitativas e o início dos agrupamentos operacionais nas suas diversas formas concretas e tipos de conversação (CARMICHAEL, 1975).

Em sua primeira fase, por volta dos 4 ou 5 anos, a criança ainda é incapaz de partilhar e assumir compromissos (MONTIGNEAUX, 2003). É somente a partir dessa idade, que ela começa a interagir de forma mais significativa com aqueles a sua volta. Esses infantes são claramente egoístas e seu comportamento é caracterizado pela centralização, tendendo a perceber apenas uma dimensão do objeto por oportunidade. Durante o período pré-operatório (dos 2 aos 7 anos), a criança passa a guiar-se fortemente pelas percepções da realidade. Ela consegue resolver problemas manipulando objetos concretos, mas tem extrema dificuldade em trabalhar abstrações (DAVIDOFF, 2001).

Em contraste com a etapa anterior, o jovem consegue gradativamente avaliar diversas dimensões de estímulos ao mesmo tempo e relacionar as dimensões de uma forma inteligente e relativamente mais abstrata. Neste contexto, espera-se que a existência de um grande número de elementos visuais de forma simultânea confunda a criança.

Nesse período, a criança começa a se expressar por meio de desenhos que representam à realidade na sua visão particular (DAVIDOFF, 2001). Nesse período se torna possível à coleta de dados de pesquisa por meio de desenhos, técnica utilizada por alguns pesquisadores da área de marketing (MCNEAL, 1992; MCNEAL, 1999; MCNEAL e JI, 2003; MCNEAL e MINDY, 1996; VELOSO e HILDEBRAND, 2007).

No decorrer deste período em particular, a criança apresenta um pensamento denominado egocêntrico. Isso significa que "[e]las tendem a enxergar o mundo essencialmente com base nas próprias perspectivas. Elas acham difícil pôr-se no lugar de outras pessoas ou até mesmo entender que existem outros pontos de vista" (DAVIDOFF, 2001, p.439). Esse tipo de análise deixa bem 
claro que algumas das ferramentas de marketing, como marketing boca-a-boca, podem não ser aplicáveis a determinados segmentos do público infantil.

A questão do egocentrismo traz outras reflexões importantes para a área de marketing. De acordo com Martí (1995), o egocentrismo decorre da incapacidade da criança entender uma perspectiva diferente da sua, e da "tendência que as próprias crianças têm para centrar-se em um só aspecto da realidade (o que estão percebendo) e a sua dificuldade para considerar as transformações que permitem passar de seu ponto de vista ao dos outros [...]" (MARTÍ, 1995, p. 146). Percebe-se que a criança apresenta características que limitam determinadas estratégias de marketing, como, por exemplo, anunciar determinado produto com base em mais de uma característica diferenciadora ou tentar convencê-la de que suas opiniões ou argumentos estão equivocados.

Já "[e]ntre os 7 e os 11 anos, as crianças desenvolvem a capacidade de usar a lógica e param de se guiar tão predominantemente pelas informações sensoriais simples para entender a natureza das coisas" (DAVIDOFF, 2001. p. 439). O autor coloca que, de acordo com Piaget, a criança estaria habilitada a realizar operações concretas, ou seja, elas conseguem lidar logicamente com objetos, baseando-se no raciocínio. Segue o pesquisador indicando que, nesse estágio, a criança ainda não está plenamente capacitada a lidar com operações abstratas. Isso significa que "elas não conseguem criticar a lógica de outra pessoa" e que "[e]las resolvem problemas por tentativa e erro em vez de usar uma estratégia eficiente e sistemática (como, por exemplo, avaliar os prós e contras de diversas soluções para escolher a melhor delas)" (DAVIDOFF, 2001, p. 440). Mais uma vez, restrições aparecem para empresas que procuram atender ao consumidor infantil, tanto para o desenvolvimento de produtos que exijam algum nível de abstração, como para apelos na propaganda.

Por fim, o indivíduo inicia a etapa das operações proposionais, dividida na fase de organização e na de aquisição da combinatória geral. A partir desse momento, os infantes progridem para um padrão mais maduro, capaz de raciocínios ainda mais complexos acerca de situações e objetos concretos e hipotéticos (CARMICHAEL, 1975). Essa idéia é suportada pelas considerações de Davidoff (2001, p. 440): "[e]ntre os 11 e os 15 anos, as crianças desenvolvem a capacidade de 
entender a lógica abstrata. Esses jovens são capazes de ponderar o possível; eles não estão mais limitados ao "aqui e agora"".

Ainda de acordo com Davidoff (2001), é nessa fase as crianças antecipam, planejam, analisam, entendem metáforas e constroem teorias. Temas como o entendimento da vida, as realidades sociais, religião, justiça, significado e responsabilidades, se tornam corriqueiros. Neste momento, a criança está plenamente apta a se tornar um consumidor consciente das suas escolhas, ou seja, ela estará no final do seu período de socialização como consumidora ${ }^{13}$.

A divisão proposta por Piaget (1959) está fundamentada na idéia de que a criança se desenvolve criando teorias sobre como o mundo funciona, conforme explica Kalil (2004, p.12-13):

Piaget afirmava que, no esforço para compreender seu mundo, as crianças agem como cientistas que criam teorias sobre os mundos físico e social. Elas tentam reunir tudo o que sabem sobre os objetos e as pessoas em uma teoria completa. As teorias das crianças são testadas diariamente pela experiência, porque as levam a esperar que certas coisas aconteçam. Como ocorre com as verdadeiras teorias cientificas, quando os acontecimentos previstos acontecem, a crença da criança em sua teoria aumenta. Quando não ocorrem, a criança precisa rever a teoria. [...] Piaget acreditava que, em certos pontos críticos de seu desenvolvimento, as crianças compreendiam que havia falhas básicas em suas teorias. Quando isso acontecia, elas revisavam as teorias, radicalmente.

Ao revisar as suas teorias, as crianças passam por mudanças fundamentais no seu entendimento do mundo. A divisão proposta por Piaget, e que é adotada por inúmeros pesquisadores da academia de marketing, fundamenta-se no momento em que essas revisões radicais ocorrem.

Luque e Palácios (1995) clarificam uma questão bastante importante com relação aos estudos de Piaget. Os autores lembram que as teorias de Piaget foram construídas basicamente com os aportes observacionais de três crianças, seus filhos. Posteriormente, foram realizadas inúmeras pesquisas, tanto longitudinais como transculturais, para verificar a validade da teoria proposta por Piaget. Os resultados destes estudos indicam que, de forma geral, Piaget foi bastante feliz nas suas considerações, mas que alguns grupos de crianças mostraram velocidades diferentes na transposição das etapas propostas pelo autor. De acordo com Luque e Palácios (1995), isso se deve a fatores externos, culturais e situacionais, que tornam a passagem da criança pelas diferentes etapas do desenvolvimento um processo mais rápido, ou mais lento. Essa linha de

\footnotetext{
${ }^{13} \mathrm{O}$ tema socialização do consumidor será abordado em tópico posterior deste trabalho.
} 
raciocínio abre caminho para as teorias do desenvolvimento baseadas no contexto onde a criança está envolvida, as quais serão abordadas posteriormente.

A visão de Piaget é complementada por outros teóricos da área do desenvolvimento infantil, os quais discutem o papel da influência ambiental no desenvolvimento da criança. Kail (2004) apresenta as idéias de Lev Vygotsky (1869-1934). Vygotsky acreditava que a criança sofre uma grande influência do contexto onde está inserida.

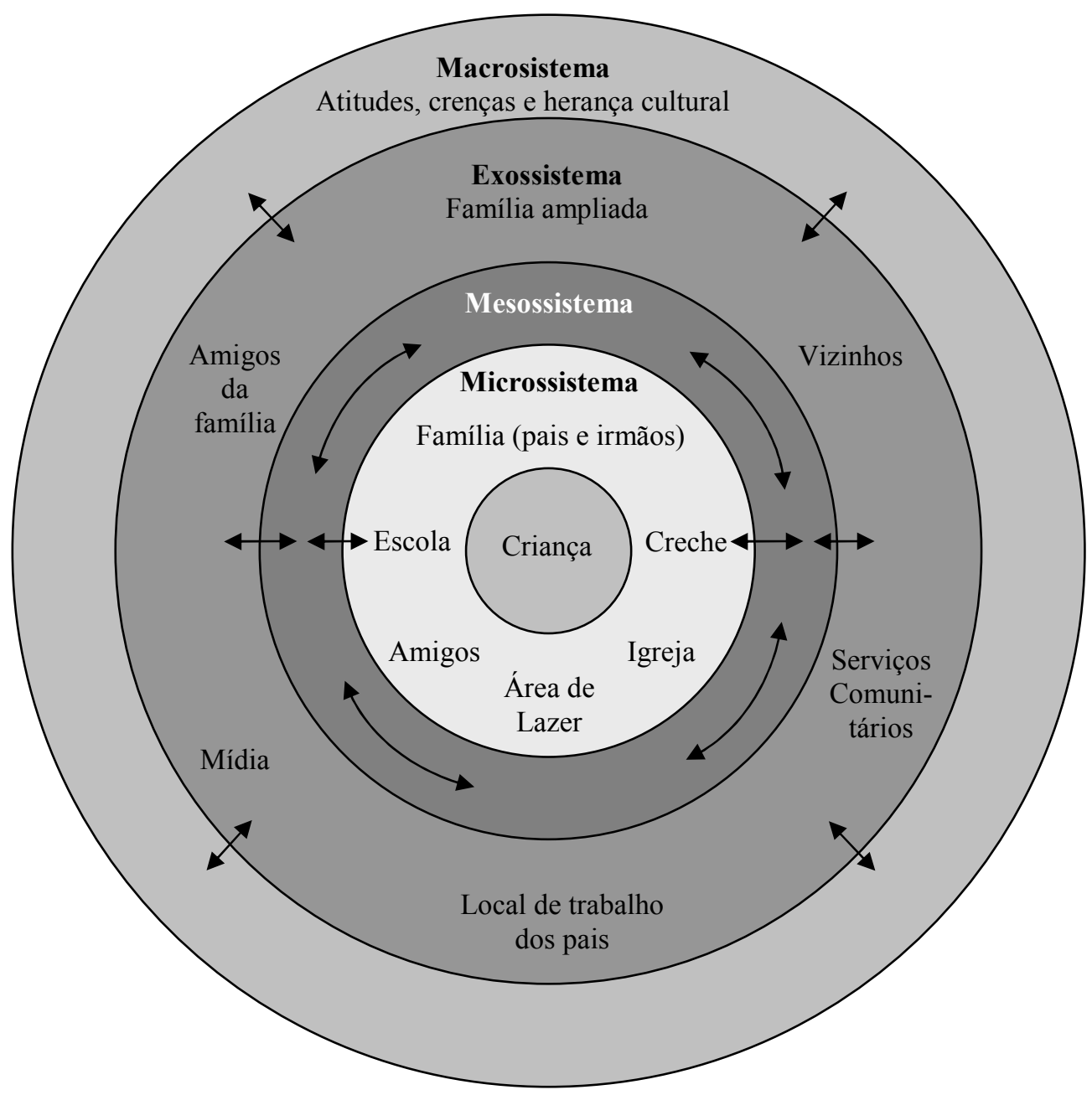

Ilustração 10 - Influências ambientais no desenvolvimento da criança FONTE: KAIL; 2004, p.16.

Bronfenbrenner, considerado um dos mais conceituados teóricos da perspectiva contextual, ampliou a visão de Vygotsky, e por meio da Ilustração 10, apresenta os diferentes grupos de influência que atuam sobre a criança (KAIL, 2004). Esses grupos são responsáveis por transmitir 
para a criança uma série de informações, que são combinadas para "formar a cultura de uma pessoa - o conhecimento, as atitudes e o comportamento associados a um grupo de pessoas" (KAIL, 2004, p.14).

Ao analisar o desenvolvimento da criança sob o enfoque contextual, é possível compreender melhor os inúmeros fatores que atuam sobre o desenvolvimento da mesma. Essa visão mais ampla traz a possibilidade da elaboração e aplicação de estratégias de marketing mais adequadas para o mercado infantil. Portanto, segue-se com a apresentação das teorias relativas ao processo de socialização, as quais permitem uma melhor compreensão da influência do contexto no desenvolvimento da criança.

\subsubsection{Variáveis de segmentação - idade - processo de socialização}

O objetivo desta sessão do trabalho é apresentar detalhadamente o processo de socialização do consumidor, abordando os principais fatores de influência. A abordagem destes fatores, permite o lançamento das bases para entender as limitações impostas às estratégias da empresa quando atuando junto ao mercado infantil. Também será possível visualizar os caminhos que podem ser trilhados para melhor compreender esse consumidor infantil e, conseqüentemente, as formas que se apresentam para atendê-lo da melhor forma.

A palavra socialização vem do francês socialisation e significa "o fato de desenvolver relações sociais entre os homens, e nelas formar um grupo, uma sociedade" (HOUAISS, 2007), ou seja, diz respeito ao processo em que o ser humano se adapta ao convívio com outras pessoas e se insere na vida em grupo. López $(1995$, p. 83) propõe que o processo de socialização é "[...] um processo interativo, necessário à criança e ao grupo social onde nasce, através do qual a criança satisfaz suas necessidades e assimila a cultura, ao mesmo tempo que, reciprocamente, a sociedade se perpetua e desenvolve.” Brée (1995) conceitua socialização como o processo através do qual os indivíduos aprendem a desempenhar efetivamente o seu papel na sociedade.

De forma geral, os conceitos supracitados estão baseados na necessidade do ser humano de se inserir no grupo em que vive. Durante este processo, o indivíduo aprende as regras que regem o 
grupo, assim como quais comportamentos são aceitos e quais não são aceitos. As regras e comportamentos que o sujeito aprende estão relacionadas com as diversas facetas que a vida em sociedade apresenta. Uma dessas facetas é o processo de socialização do consumidor, ou seja, o aprendizado das regras que regem a questão do consumo.

McNeal (2007), em seu livro mais recente, desenvolve seu raciocínio considerando os indivíduos como consumidores 24/7/360. Para o autor, os indivíduos estão envolvidos no consumo ou na compra de bens todo o tempo e, por isso, o estudo do processo de socialização deveria ser mais profundamente estudado pela academia.

Independentemente do grupo onde está inserido, o pesquisador que se debruça sobre este tema deve entender que o processo de socialização envolve três diferentes facetas (LÓPEZ, 1995, p. 83):

1. Processos mentais de socialização: aquisição de conhecimentos sociais;

2. Processos afetivos de socialização: formação de vínculos;

3. Processos condutuais de socialização: conformação social da conduta.

De acordo com o autor, os processos mentais de socialização formam a base para os outros dois processos - o conhecimento referente às pessoas e o da sociedade, detalhados a seguir (LÓPEZ, 1995, p,84):

1. Conhecimento referente às pessoas:

- Reconhecimento, identidade e papéis.

- Diferenciação entre conhecidos e estranhos.

- Sentimentos, pensamentos, intenções e pontos de vista dos demais.

- Relações entre as pessoas: amizade, relações familiares etc. 
2. Conhecimento da sociedade:

- Conhecimentos sociais: dinheiro, pobre, rico, nação, cidade etc.

- Conhecimento das instituições: família, escola, hospital, parlamento etc.

- Conhecimento dos valores, normas juízo moral etc.

Os processos afetivos de socialização envolvem a formação de vínculos com os pais, irmãos, amigos etc. (LÓPEZ, 1995). Essa colocação está diretamente relacionada às questões levantadas anteriormente no tópico referente ao desenvolvimento baseado no contexto, reforçando a importância das teorias do desenvolvimento contextual para o entendimento do desenvolvimento da criança.

Os processos condutuais de socialização indicam que a criança deve aprender a conduta que se espera dela, para assim poder se adequar corretamente ao grupo em que está inserida (LÓPEZ, 1995). O autor agrega tecendo considerações sobre comportamentos que devem ser evitados para uma melhor inserção do indivíduo em sociedade. De acordo com o pesquisador, o processo de socialização envolve não só o que deve ser feito, mas também o que deve ser evitado.

Dessa forma, "se a criança vincula-se afetivamente a determinados adultos, se adquire o conhecimento do que a sociedade é e o que se espera dela, e se tem um comportamento adequado a estas expectativas, estará bem socializada." (LOPÉZ, 1995, p. 84).

Com base em considerações anteriores, percebe-se a importância do aprendizado relacionado à integração a uma sociedade de consumo. Torna-se parte imprescindível da vida em sociedade o aprendizado referente ao consumo.

É possível entender a pertinência deste tema para os profissionais de marketing com base nas explicações de Moschis e Churchill (1978) sobre os grupos que têm interesse no campo dos estudos voltados ao processo de socialização do consumidor: 
- Responsáveis por políticas públicas: buscam entender o efeito das atividades de marketing no comportamento do consumidor, na formação dos seus valores e de suas atitudes.

- Profissionais de marketing: buscam melhorar os esforços de comunicação direcionados ao segmento em questão.

- Educadores: buscam entender como os jovens desenvolvem habilidades para lidar com os estímulos (principalmente comerciais), visando ensinar-lhes como se portar no mercado de forma mais efetiva.

- Estudantes de socialização e comportamento do consumidor: buscam entender melhor uma área de pesquisa que promete gerar significativos aportes no entendimento do comportamento do consumidor.

Ward (1974) suscita que é de conhecimento comum dentro do campo das ciências comportamentais que as experiências vividas durante a infância são fundamentais na formação e na determinação dos padrões de cognição, bem como no comportamento da vida adulta. Trazendo essas colocações para a área de comportamento do consumidor, o autor ressalta que seria possível entender ou até mesmo prever o comportamento de adultos com base nas experiências que esse indivíduo teve durante sua infância. Também seria possível, completa, desenvolver políticas públicas e programas de educação do consumidor.

Por último, Ward (1974) tece considerações sobre o uso desse conhecimento para criar programas de marketing mais apropriados, ou mais ajustados para o público infantil. O autor foca o seu trabalho no processo de aquisição dos conhecimentos necessários para que o indivíduo se torne um consumidor ajustado às expectativas da sociedade. Partindo deste pressuposto, talvez seja necessário inserir a questão da cultura no estudo do processo de socialização, tendo em vista a questão da expectativa da sociedade com relação às características esperadas de um consumidor. 
O processo mencionado acima é denominado de processo de socialização do consumidor, ou seja, é o "processo por meio do qual pessoas jovens adquirem habilidades, conhecimentos e atitudes relevantes para seu funcionamento como consumidora no mercado" (WARD, 1974, p. 2). Moschis e Churchill (1978, p. 599) seguem linha de raciocínio semelhante e colocam que socialização do consumidor é o "[...] processo por meio do qual pessoas jovens desenvolvem habilidades, conhecimento e atitudes relacionadas ao consumo."

É importante salientar que o foco deste trabalho é o consumidor infantil e, por conseqüência, o centro do processo de socialização do consumidor também deve ser o período da infância. Contudo, como coloca Ward (1974), nem todo o processo de socialização ocorre durante a infância. A adolescência também traz aprendizados e desenvolvimentos para o indivíduo (MOSCHIS e MOORE, 1978), assim como a maior idade (SMITH e MOSCHIS, 1984).

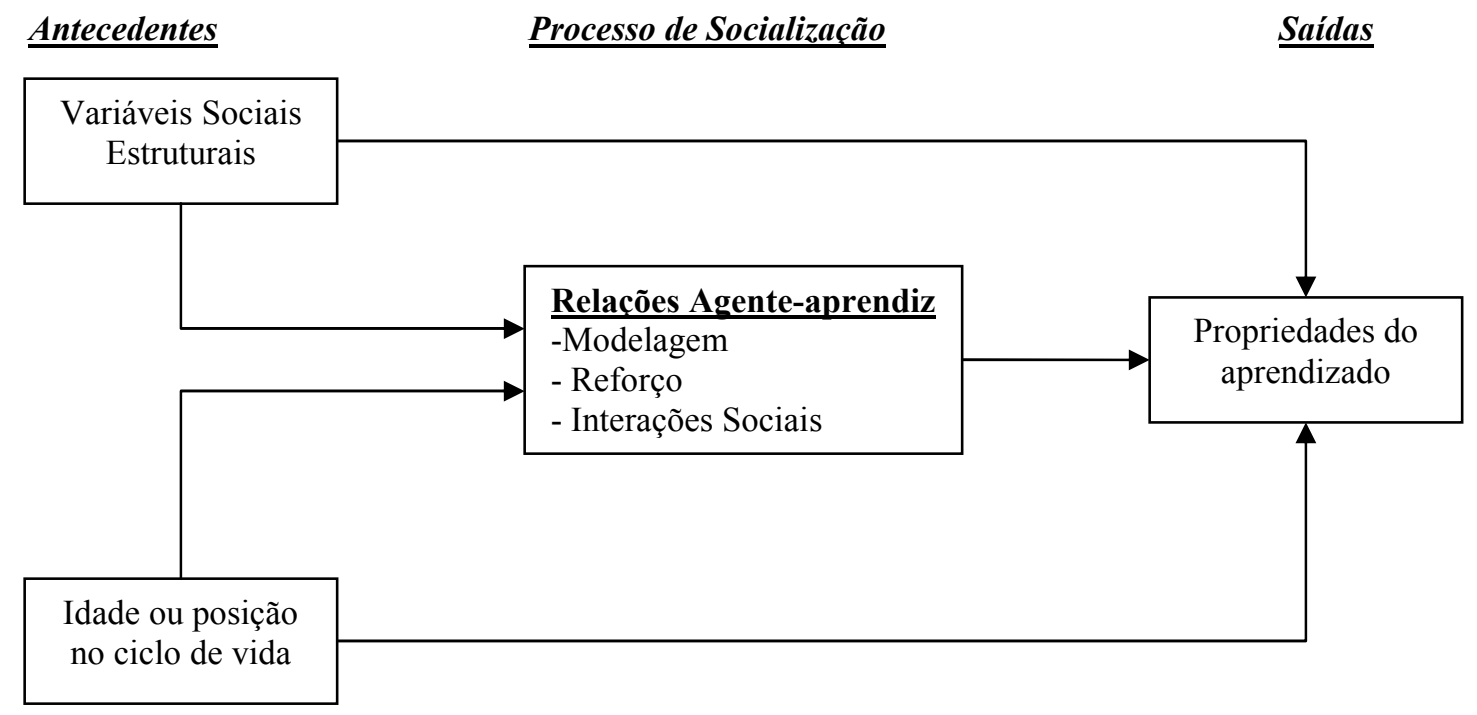

Ilustração 11 - Processo de socialização de Moschis e Churchill FONTE: MOSCHIS e CHURCHILL; 1978, p. 600.

O agente de socialização, apresentado por Moschis e Churchill (1978) na Ilustração 11, pode ser entendido como qualquer pessoa ou organização envolvida que tenha certa freqüência de contato com o sujeito, tenha algum tipo de primazia ou controle sobre as recompensas ou punições direcionadas ao mesmo. As variáveis estruturais indicadas pelos autores são: classe social e sexo, pois ambas podem influenciar diretamente o indivíduo em seu processo de aquisição de conhecimento. 
Ainda no mesmo contexto, idade e ciclo de vida são pertinentes ao processo, pois é durante os primeiros anos de vida da criança que o seu processo de socialização se desenvolve de forma mais intensa, assim como o seu processo de socialização como consumidora. De acordo com Moschis et al. (1984), existem diferenças de aprendizado entre grupos de crianças com idades distintas, ou seja, crianças mais velhas tendem a apresentar competências superiores. Merece consideração o fato de que a idade traz consigo uma gama de experiências (na escola, no domicílio e com colegas) que também são responsáveis pelo aprendizado.

McNeal (1999) considera que o desenvolvimento da criança como consumidora é uma curva em $\mathrm{S}$, demonstrando que o aprendizado tem seu grande salto entre os 5 e 8 anos (vide Ilustração 9). De acordo com a teoria de Moschis e Churchill (1978), apresentada na Ilustração 11, esse processo de socialização acontece por meio das relações entre o indivíduo e os seguintes agentes: mídia de massa, escola, pais e colegas (outras crianças). Analisando a Ilustração 9 com base nas afirmações de Moschis e Churchill (1978), é possível perceber a lógica que fundamenta a figura. McNeal (1999) visualiza o desenvolvimento maior da criança como consumidora justamente na época em que o número de agentes de socialização que a influenciam aumenta. É a partir dos 6 ou 7 anos que o contato da criança com a escola e com colegas passa a ser considerável, sendo então natural que ocorra nesse momento um crescimento das suas capacidades. Moreno e Cubero (1995) destacam que no processo de socialização em geral a escola tem um papel preponderante. Cabe salientar que ambas as considerações, tanto a de Moschis e Chuchill (1978), como a de McNeal (1999), trazem embutidas a questão do desenvolvimento cognitivo conforme coloca Piaget apud Kail (2004).

Para melhor compreender a socialização e como os agentes participam do processo, Montigneaux (2003) apresenta os períodos da infância, esclarecendo a evolução do processo de socialização, desejo de autonomia da criança e o seu desenvolvimento e aprendizado. 
Quadro 6 - Os períodos da infância

\begin{tabular}{|c|c|c|c|c|}
\hline & Níveis de Idade & Socialização & Autonomia & $\begin{array}{c}\text { Desenvolvimento } \\
\text { \& Aprendizado }\end{array}$ \\
\hline $\begin{array}{l}\text { Recém-Nascidos e } \\
\text { lactentes }\end{array}$ & $0-24$ meses & $\begin{array}{l}\text { Relação dual } \\
\text { mãe/criança }\end{array}$ & Forte dependência & \\
\hline $\begin{array}{l}\text { Crianças na tenra } \\
\text { infância }\end{array}$ & $2-4$ anos & Centrada em si & \multirow{2}{*}{ Dependência } & \multirow{2}{*}{$\begin{array}{l}\text { Desenvolvimento } \\
\text { da linguagem }\end{array}$} \\
\hline $\begin{array}{l}\text { Crianças em } \\
\text { idade pré-escolar }\end{array}$ & 4-6 anos & $\begin{array}{l}\text { Entrada no } \\
\text { maternal }\end{array}$ & & \\
\hline Juniores & 6-9 anos & $\begin{array}{l}\text { Escola } \\
\text { primária/melhor } \\
\text { amigo }\end{array}$ & $\begin{array}{l}\text { Desejo de } \\
\text { independência }\end{array}$ & Leitura/escrita \\
\hline Pré-adolescentes & 9-11 anos & Grupo de amigos & Independência & Abstração \\
\hline
\end{tabular}

FONTE: MONTIGNEAUX; 2003, p.67.

No contexto das influências do processo de socialização percebe-se, a partir do Quadro 6, que a criança passa a sofrer maiores influências quando passa a conviver com outras crianças. Isso é explicado pelo desenvolvimento da criança, visto que, ao atingir determinada idade, ela passa a se comunicar com outras crianças, passa a ler e a escrever e por fim consegue abstrair o significado das coisas. Essa análise, quando tomada em conjunto com a Ilustração 9 e a Ilustração 11, permite uma compreensão mais aprofundada do processo de desenvolvimento da criança, com base no processo de influência dos agentes de socialização e desenvolvimento da criança.

Roedder-John (1999) amplia os itens apresentados por Moschis e Churchill (1978) com base em extensa revisão teórica, utilizando artigos publicados entre 1974 e 1998. Para a autora, as influências são: família, cultura, colegas, mídia de massa e marketing. A diferença encontra-se na inserção da cultura e do marketing em conjunto com a mídia de massa. O item cultura é agregado à lista de fatores influenciadores em função de a academia de marketing ter evoluído do foco exclusivamente americano das décadas de 60 e 70, para um foco mais abrangente, absorvendo inclusive a questão das minorias imigrantes nos EUA.

Olhando por um outro lado do prisma, os dados apresentados por Rideout (2007), com base em estudo conduzido com uma amostra nacional de 1000 respondentes, permitem visualizar a opinião dos pais sobre as diferentes fontes de influências que atuam sobre a criança. 
Tabela 1 - Opinião dos pais sobre as diversas fontes de influências sobre o comportamento das crianças

\begin{tabular}{|l|c|c|c|c|c|}
\hline & Muito & Alguma & Apenas um pouco & Nenhuma & Não respondeu \\
\hline Seus professores & $54 \%$ & $35 \%$ & $5 \%$ & $3 \%$ & $3 \%$ \\
\hline Seus amigos & $42 \%$ & $34 \%$ & $16 \%$ & $7 \%$ & $1 \%$ \\
\hline Você (pais) & $83 \%$ & $11 \%$ & $3 \%$ & $2 \%$ & $0 \%$ \\
\hline Mídia & $23 \%$ & $34 \%$ & $27 \%$ & $15 \%$ & $1 \%$ \\
\hline
\end{tabular}

FONTE: Adaptado de RIDEOUT; 2007, p.15.

Com base na Tabela 1, pode-se concluir que os pais dão uma importância muito maior para a sua própria influência e para a influência dos professores dessas crianças. Os amigos aparecem posteriormente, seguidos pela mídia, considerada o fator de menor impacto.

Percebe-se, pelo que foi apresentado até este momento, que é importante analisar de forma mais profunda os diferentes agentes de socialização. $\mathrm{O}$ entendimento do impacto e da interferência de cada um dos agentes trará uma melhor compreensão das possibilidades estratégicas de uma empresa que deseje atuar neste campo. Nos próximos itens deste trabalho, serão apresentados cada um dos agentes de socialização mencionados anteriormente.

\subsubsection{A mídia de massa}

Desde a época de Platão, existem indícios na literatura sobre a influência de "histórias de fora" sobre as crianças (ROBERTS et al., 1999). Platão defende, no livro "A República", a necessidade de algum tipo de censura para proteger as crianças das "histórias de fora." Essas histórias são informações que chegam às crianças por algum meio disponível, ou seja, por alguma mídia (ROBERTS et al., 1999). Desde então, tem sido constante a preocupação com as informações que são disponibilizadas pelos meios de comunicação social. Com o desenvolvimento das diferentes formas de mídia, no decorrer do século XX, cresceu o impacto que a mídia exerce sobre as crianças. Na Tabela 2, são apresentados números referentes à disponibilidade de acesso aos diferentes tipos de mídia no quarto de crianças norte-americanas. 
Tabela 2 - Disponibilidade dos diversos tipos de mídia no quarto das crianças norte americanas

\begin{tabular}{|l|c|c|c|}
\hline & \multicolumn{3}{|c|}{ IDADE } \\
\hline MíDIA & $\mathbf{2 - 4}$ anos & $\mathbf{5 - 7}$ anos & $\mathbf{8 - 1 3}$ anos \\
\hline Televisão & $26 \%$ & $39 \%$ & $65 \%$ \\
\hline Vídeo-Cassete & $14 \%$ & $18 \%$ & $34 \%$ \\
\hline Rádio & $32 \%$ & $53 \%$ & $81 \%$ \\
\hline Toca-Fita & $32 \%$ & $41 \%$ & $74 \%$ \\
\hline CD Player & $9 \%$ & $18 \%$ & $64 \%$ \\
\hline Vídeo Game & $7 \%$ & $18 \%$ & $47 \%$ \\
\hline Computador & $4 \%$ & $9 \%$ & $23 \%$ \\
\hline TV a Cabo ou Satélite & $10 \%$ & $18 \%$ & $28 \%$ \\
\hline Canais Premiun na TV Paga & $4 \%$ & $5 \%$ & $15 \%$ \\
\hline Internet & $1 \%$ & $2 \%$ & $9 \%$ \\
\hline Drive CD-ROM & $1 \%$ & $5 \%$ & $14 \%$ \\
\hline
\end{tabular}

FONTE: ROBERTS et al. ; 1999, p. 13.

Dentre os diversos tipos de mídia que estão presentes no quarto das crianças, destaca-se a televisão (com ou sem a presença de canais pagos) como um dos meios que mais permite a comunicação entre as empresas e as crianças (ROBERTS et al., 2005). Por meio da televisão e dos diferentes tipos de canais, as empresas conseguem transmitir suas mensagens, utilizando tanto propagandas, quanto inserções comerciais e colocação de produtos ${ }^{14} \mathrm{em}$ séries, filmes etc.

No centro do debate acerca do impacto da propaganda sobre as crianças, estão as vulnerabilidades próprias desse público (MOORE, 2004; MOSES e BALDWIN, 2005). Essa vulnerabilidade decorre da abertura que a criança dá para novas informações (MOSES e BALDWIN, 2005). Essa condição da criança faz com que se torne necessário questionar se é apropriado expor a criança a comerciais sofisticados e em alguns casos enganadores (MOSES e BALDWIN, 2005).

Essas preocupações datam do início da década de 70, quando foram estruturadas as primeiras iniciativas no sentido de estudar o impacto das propagandas e controlar a quantidade de apelos que atingiam as crianças (JOHN, 1999). Essas ações tomaram lugar tanto nos Estados Unidos como na Europa, onde o desenvolvimento tecnológico e as exigências colocadas pela União Européia para harmonizar a legislação geraram um aumento das investidas nesta área de pesquisa durante os últimos 10 anos (OATES et al., 2003). John (1999) acrescenta ao debate destacando

\footnotetext{
${ }^{14}$ Do conceito Product Placement, aqui traduzido por colocação de produto.
} 
alguns dos pontos mais analisados e estudados pelos estudiosos do impacto da mídia televisiva sobre a criança:

- Capacidade de distinguir entre comerciais e a programação normal (filmes, séries, etc).

- Capacidade da criança em entender as intenções de um comercial.

Antes de ter a capacidade de entender um comercial, a criança necessita saber distinguir a propaganda da programação normal da televisão (MOSES e BALDWIN, 2005). Essa diferenciação não pode ser apenas baseada em fatores superficiais que podem não ter nada a ver com as diferenças críticas entre um comercial e a programação.

Seguindo essa mesma idéia, John (1999) afirma que é por volta dos 5 anos que a criança começa a perceber a diferença entre comerciais e a programação televisiva. Brée (1995), em um importante esforço de revisão bibliográfica, questiona os resultados encontrados pela literatura. De acordo com o pesquisador, existem trabalhos que afirmam que crianças de 4 ou 5 anos já reconhecem essas diferenças, assim como existem trabalhos posicionam esse evolução somente durante os 6 ou 7 anos. Já outros trabalhos analisados pelo autor consideram que parte das crianças somente adquire a capacidade de diferenciar entre um comercial e a programação normal da televisão por volta dos 10 ou 11 anos.

Essa profusão de resultados é resultado dos diferentes enfoques metodológicos utilizados (BRÉE, 1995). A questão metodológica aqui colocada surge nos métodos de coleta dos dados. Enquanto alguns trabalhos utilizam medidas verbais outros utilizam medidas não verbais. Os métodos verbais podem produzir resultados enganadores na opinião de Moses e Baldwin (2005), pois as crianças ainda não estão suficientemente desenvolvidas para realmente compreender as questões colocadas pelos pesquisadores (DONOHUE et al., 1980).

[...] nós acreditamos que os pesquisadores não podem realisticamente determinar como a televisão afeta as crianças com uma mínima acuracidade enquanto eles utilizarem as habilidades verbais como ferramenta metodológica. (DONOHUE et al., 1980, p. 56). 
Essas considerações direcionaram alguns autores a realizarem estudos exclusivamente qualitativos, com o apoio da técnica de grupo de foco (LAWLOR e PROTHERO, 2003; DONOHUE et al., 1980; OATES et al., 2003) ou entrevistas em profundidade (CHAN, 2000) para coletar dados relacionados ao tema.

Em muitos casos, principalmente para crianças com uma idade inferior, o reconhecimento de que aquilo que está sendo transmitido é um comercial ainda não se relaciona com uma perfeita percepção do significado de uma propaganda (BRÉE, 1995). Essas crianças parecem reconhecer a diferença com base em fatores como a duração (comerciais são mais curtos) e o nível de entretenimento oferecido (comerciais são mais divertidos) (BRÉE, 1995; MOSES e BALDWIN, 2005).

Martin (1997) realizou uma meta-análise acerca da influência da mídia e conclui avaliando que diferenças nas metodologias utilizadas explicam a variância nos resultados que buscam entender a relação entre idade e nível de entendimento do objetivo do comercial. Os resultados de Martin (1997) são corroborados pelas considerações de John (1999), a qual propõe que questionamentos podem ser levantados quanto à capacidade da criança em reconhecer o objetivo do comercial, ou conforme esclarecem Moses e Balwin (2005), convencer o receptor da mensagem a mudar de atitude ou comprar produtos ou serviços. Quando a criança ainda não reconhece esse objetivo, ela ainda não pode criticamente avaliar determinado comercial.

A diferenciação entre um comercial e a programação normal da televisão se torna ainda mais confusa quando o comercial é desenvolvido utilizando insumos ou formatos oriundos da programação normal (BRÉE, 1995). Dessa forma, quando são utilizados personagens de desenhos, filmes ou atores do cinema ou televisão, a criança se confunde e não consegue identificar perfeitamente as diferenças. Essas colocações permitem entender as considerações de Khatibi et al. (2004), os quais indicam que as empresas estão desenvolvendo comerciais direcionados a crianças de todas as idades por muitos anos.

Esses comerciais têm sido alvo de inúmeras críticas, pois são direcionados para um público que não é maturo o bastante para avaliar de forma critica as mensagem recebidas. Essa situação é 
mais problemática quando a criança não reconhece que se trata de um comercial, embora não deixe de ser merecedora de atenção quando a criança consegue reconhecer essa diferença.

Apesar da pesquisa realizada por Khatibi et al. (2004) demonstrar que grande parte das crianças entre 5 e 8 anos reconhece um comercial, apenas 31,1\% das crianças pesquisadas reconhecem que um comercial tenta vender coisas, tenta fazer dinheiro ou mostra coisas que podem ser compradas. Khatibi et al. (2004) finalizam seu trabalho apresentando como limitação a raça das crianças pesquisadas (principalmente indianas e chinesas). Essas considerações podem ser relacionadas com a avaliação de Brée (1995) sobre os diversos resultados encontrados na literatura em relação às questões em discussão neste momento. Além de problemas de enfoque metodológico (MARTIN, 1997; BRÉE, 1995), problemas relacionados a diferenças culturais podem ser responsáveis pelos resultados inconclusivos nos estudos que tentaram identificar a capacidade da criança em distinguir entre um comercial e a programação normal da televisão.

Moore (2004) expande as questões sobre a capacidade da criança em distinguir entre comerciais e a programação televisiva para as novas iniciativas sendo desenvolvidas pelas empresas. Entre essas novas iniciativas, a autora destaca o desenvolvimento de comerciais que parecem entretenimento, mas que, na realidade, têm como objetivo transmitir os valores da marca e criar uma percepção positiva das marcas da empresa. A autora também destaca o desenvolvimento de sites, com jogos e brincadeiras, que buscam oferecer momentos de entretenimento às crianças e ao mesmo tempo trabalhar as marcas e produtos da empresa.

Outras iniciativas incluem o lançamento de revistas destinadas ao público infantil e que estão recheadas de brindes e jogos patrocinados por marcas e produtos, assim como a colocação de produtos em programas variados (filmes, séries etc). Moses e Baldwin (2005) avaliam as diferentes técnicas de marketing (informerciais, comerciais pela internet e merchandising), colocando que essas iniciativas são ainda mais sofisticadas no sentido de persuadir os receptores das mensagens, portanto, merecem estudos mais aprofundados.

A colocação de produtos em programas que são vistos pelas crianças, parece ter um impacto bastante significativo em seu comportamento. Auty e Lewis (2004) conduziram um experimento 
com crianças entre 6 e 12 anos e detectaram que a colocação de produto pode impactar as escolhas das crianças de forma significativa. Auty e Lewis (2004) selecionaram dois trechos do filme Esqueceram de Mim $^{15}$. Num desses trechos do filme são feitas menções à Pepsi e mostra-se uma lata do refrigerante. $\mathrm{O}$ outro trecho do filme não apresentava nenhuma marca de refrigerante. Após a exibição dos filmes, as crianças tinham a chance de escolher um refrigerante para tomar, sendo as opções disponíveis Coca-Cola e Pepsi. Os resultados foram: 58\% Coca-Cola e 42\% Pepsi (grupo de controle); 38\% Coca-Cola e 62\% Pepsi (grupo que viu filme onde aparecia a Pepsi). Os números gerais da Grã-Bretanha, onde foi realizado o estudo, tem uma distribuição de $75 \%$ das vendas para a Coca-Cola e $25 \%$ para a Pepsi.

Resultados apresentados por Ward e Wackman (1974), indicam que as crianças que estão atravessando a fase operacional-concreta do desenvolvimento cognitivo - 7 aos 11 anos, (KAIL, 2004) - apresentam um melhor entendimento das intenções de um comercial e são mais céticas com relação aos apelos da propaganda. De acordo com os autores, essa percepção surge nas crianças com base em experiências negativas com comerciais que prometem demais ou produtos que entregam de menos, corroborando os resultados de Oates et al. (2003).

Moschis (1981) pondera acerca do assunto e, fundamentado em pesquisa empírica, clama mudanças nas políticas públicas que tentam proteger a criança do impacto da mídia. Segundo o pesquisador, as políticas da época não eram adequadas, pois focavam crianças abaixo dos 12 anos, sendo que os resultados de sua pesquisa colocam crianças no começo da adolescência como ainda em estágio de desenvolvimento das suas capacidades cognitivas que permitem entender melhor o significado de um comercial.

O Quadro 7, produzido por Oates et al. (2003, p.61), traz os resultados de pesquisa qualitativa conduzida por meio de grupos de foco com crianças britânicas entre 6 e 10 anos.

\footnotetext{
${ }^{15}$ Filme intitulado Home Alone, dirigido por Chris Columbus em 1990.
} 
Quadro 7 - Entendimento da natureza da propaganda

\begin{tabular}{|l|l|}
\hline Idade & \multicolumn{1}{c|}{ Nível de entendimento } \\
\hline 6 anos & $\begin{array}{l}\text { Os comerciais são feitos para que os telespectadores e os atores possam descansar. } \\
\text { Os comerciais contam o que vai passar na televisão e o que está presente nas lojas. } \\
\text { Os comerciais são apreciados, menos aqueles direcionados para bebês ou crianças mais novas. } \\
\text { Comercias são percebidos como acontecendo em tempo real. }\end{array}$ \\
\hline 8 anos & $\begin{array}{l}\text { Os comerciais são um descanso e para informar, mas fatores econômicos começam a aparecer. } \\
\text { Pouca percepção da natureza persuasiva do comercial. } \\
\text { Experiência pessoal começa a influenciar as opiniões sobre os comerciais, mas apenas em } \\
\text { situações especificas. } \\
\text { Os comercias são percebidos como acontecendo em tempo real. }\end{array}$ \\
\hline 10 anos & $\begin{array}{l}\text { Os comerciais ainda são vistos como uma razão para descansar e para informar, mas a } \\
\text { persuasão surge como base para explicar situações pessoais de desilusão. } \\
\text { O conceito de que os comerciais são previamente gravados para depois serem televisionados } \\
\text { surge mais frequentemente. }\end{array}$ \\
\hline
\end{tabular}

FONTE: OATES et al.; 2003, p.61

Os resultados apresentados por Oates et al. (2003, p.61) são similares aos resultados encontrados por Chan (2000), que pesquisou indivíduos de Hong Kong. A autora considera que a classificação de desenvolvimento criada por Piaget é bastante adequada para a análise da relação da criança com a propaganda. Os resultados de Chan (2000) trazem importantes reflexões sobre o impacto da cultura sobre o processo de socialização. As crianças de Hong Kong e do Reino Unido apresentam resultados similares no que se refere ao entendimento da natureza da propaganda. O fato pode ter ocorrido em função de as culturas serem similares (Hong Kong é uma ex-colônia inglesa recentemente incorporada à China), ou em razão de um impacto pequeno da cultura neste específico tópico do processo de socialização. Essa é uma questão que merece maiores aprofundamentos por parte da academia de marketing.

As crianças mais novas indicam receber informações de novos produtos principalmente de visitas a lojas, já crianças mais velhas indicam que a mídia, principalmente a televisão, é a fonte mais importante de informações sobre novos produtos (WARD e WACKMAN, 1974). Esses resultados indicam que, conforme envelhecem, as crianças se tornam mais conscientes do papel da mídia como fonte de informações sobre produtos e serviços.

Cabe aqui colocar as considerações de Moses e Baldwin (2005). Os autores consideram que não basta o jovem ter o conhecimento dos conceitos relacionados ao entendimento do que é uma propaganda, ele tem que saber utilizar esses conceitos em ocasiões reais. Dessa forma, não seria o bastante a criança entender que o comercial traz informações sobre produtos e serviços ou que o 
tem como objetivo vender alguma coisa. O infante teria que colocar esses conceitos em prática na hora de avaliar determinado apelo, para assim tomar decisões de consumo mais adequadas.

A mídia de massa tem sua influência mediada pelo comportamento dos pais. De acordo com Neeley (2005), os pais podem influenciar o impacto da mídia quando compartilham com a criança o momento de interação com uma determinada mídia. Isso acontece com maior freqüência na mídia televisiva, por se tratar de uma mídia consumida em grupo. Nesse sentido, existem alguns momentos em que os pais podem influenciar o impacto da mídia televisiva, como, por exemplo, a escolha dos programas que irão assistir no momento em que os filhos estão presentes, os comentários realizados sobre o que está sendo televisionado (programas e propagandas) e as atitudes dos pais perante as propagandas.

Conforme as crianças vão crescendo, a sua liberdade para escolher livremente os programas que irão assistir aumenta (NEELEY, 2005). Isso indica claramente que o impacto dos pais como mediadores da influência da mídia decresce com o passar dos anos. Outro fator que indica o decréscimo do impacto dos pais é a presença cada vez maior de televisores no quarto das crianças. Atualmente, $52 \%$ dos lares americanos permitem que a criança tenha um televisor no seu quarto (ROBERTS, 2007), diminuindo assim o papel dos pais no processo.

Apresentou-se neste tópico, as principais considerações sobre o impacto da mídia sobre as crianças. Optou-se por uma abordagem que privilegiou a questão do entendimento da propagada por parte das crianças, pois é um tema que deve fazer parte das discussões sobre a utilização das ferramentas de comunicação com crianças abaixo de determinada idade. Também foi possível compreender melhor quais as mídias com as quais os infantes têm uma maior proximidade ao longo do seu desenvolvimento, possibilitando assim a escolha mais apropriada da mídia a ser utilizada pelas empresas, tendo em vista a faixa etária a qual quer atender.

\subsubsection{A escola}

Embora a família constitua em um primeiro momento o meio de desenvolvimento mais imediato para a criança, a escola transforma-se logo em um importante contexto de socialização. Todas as culturas possuem sistemas organizados, de maior ou menor complexidade, mediante os quais os indivíduos adultos preparam os jovens para sua incorporação à sociedade. Nas sociedades industriais desenvolvidas, a escola é, por excelência, a instituição encarrega da transmissão dos conhecimentos e 
valores da cultura e, portanto, de prepara as crianças para o desempenho adequado do papel adulto ativo nas estruturas sociais estabelecidas. Moreno e Cubero (1995, p.198-199).

A partir da contextualização que Moreno e Cubero (1995) oferecem, parte-se para compreender como a sociedade tem visualizado o papel da escola no contexto do processo de socialização do consumidor. Brée (1995) traz uma visão interessante sobre como o poder público pode proteger as crianças de eventuais abusos cometidos por empresas ou outras instituições:

- A primeira opção seria estabelecer uma legislação bastante severa com o objetivo de limitar de forma considerável a margem de manobra da indústria.

- A segunda opção seria ensinar as crianças a se defenderem e a reagirem como consumidores prevenidos, ajudando-as a argumentar contrariamente e a desenvolver uma análise correta.

O pesquisador analisa a história norte-americana e verifica que a primeira opção foi a mais procurada durante muito tempo, principalmente durante as décadas de 60 e 70 . Foi nessa época que as restrições mais severas tentaram ser aprovadas por organismos do governo americano, como as iniciativas da FTC - Federal Trade Comission (JOHN, 1999; SCHOR, 2004; MOSCHIS, 1981).

A segunda opção passa a ser bastante privilegiada nos tempos atuais, pois a escola tem como vocação preparar as crianças para que desempenhem seu papel de adulto na sociedade, ensinando-lhes o que é necessário para se tornar um bom cidadão e a ser economicamente autosuficiente (BRÉE, 1995).

Uma pesquisa realizada por Moschis e Moore (1978) com 607 crianças e adolescentes traz indícios de que a escola não tem sido responsável pelo aprendizado de questões relacionadas ao consumo ou de comportamentos desejáveis num consumidor. Esse resultado pode ser decorrente da época em que foi realizado o estudo, caso seja levado em consideração que, a escola foi recentemente considerada responsável pela educação das crianças nas questões do consumo 
(BRÉE, 1995), embora Stampfl et al. (1978) sugerirem desde o fim da década de 70 que as escolas deveriam assumir essa responsabilidade.

Os comentários dos autores supracitados são direcionados para tornar a criança mais capaz e auto-suficiente no mercado, dando-lhe ferramentas para se proteger de um eventual abuso por parte das empresas. Eles dão início a estudos que tentam compreender o papel da escola no processo de socialização do consumidor.

De acordo com Stampfl et al. (1978), a escola deve iniciar apresentando aos alunos os conceitos econômicos (propriedade privada, dinheiro e preço). Derivando desses conceitos, a escola deveria ensinar o conceito de troca, ou seja, o dinheiro como meio de conseguir coisas. Também deve a escola ensinar como os pais trocam o trabalho por dinheiro.

Ainda de acordo com Stampfl et al. (1978), o segundo grupo de conceitos que a escola deve trabalhar são os conceitos de distribuição (papel do varejista, sortimento da loja, linhas de produtos e marcas). Com base nesses conceitos a criança deve compreender que produtos estão disponíveis em que tipos de lojas e para que servem as marcas. Também é necessário que a criança compreenda o processo de troca, os papéis que existem no processo (consumidor e ofertante) e como ocorre a transferência de propriedade.

Por último, Stampfl et al. (1978) acreditam que a escola deveria apresentar aos alunos o processo de decisão do consumidor:

- Identificação da necessidade - como surge a necessidade ou desejo de obter a propriedade de um bem. Nesse momento a escola deve trabalhar para ensinar às crianças os diferentes tipos de apelos que existem (racionais ou emocionais).

- Busca de informações e avaliação das alternativas - como a criança pode coletar informações para tomar uma decisão mais acertada acerca daquilo que deseja comprar. A escola deve mostrar à criança que ir as compras nada mais é do que 
coletar informações nas diferentes lojas para escolher o bem que tem mais chances de satisfazer o seu desejo.

- Decisão de compra - a escolha final do bem a ser comprado e o papel de conceitos como orçamento, poder de compra e preferências pessoais nesse processo.

- Compra - o momento em que ocorre a troca monetária. A criança deve compreender que para obter um bem é necessário entregar algum valor em dinheiro. Neste momento a escola deve se preocupar em explicar a questão da troca e as diferentes denominações do dinheiro (moedas, notas e os diferentes valores que cada uma representa).

Brée (1995) destaca que não basta apenas definir o que deve ser ensinado às crianças. Também é necessário definir um método de ensino mais adequado para ensinar as questões relacionadas ao consumo. Stampfl et al. (1978) dedicaram esforços para trazer informações sobre os métodos mais adequados de ensino e verificaram que o ensino formal, em contraposição a um ensino mais aberto, foi mais adequado para transmitir os rudimentos $\mathrm{e}$ as bases necessárias para $\mathrm{o}$ desenvolvimento da criança como consumidora.

Verifica-se que é cada vez mais forte a presença das empresas por meio de ações de marketing nas escolas norte-americanas (LINN, 2004; SCHOR, 2004). Linn (2004) coloca que no início da década de 90 começou um processo de tomada das escolas por parte das empresas. Iniciativas como patrocínio de material escolar, de viagens, ginásios, edifícios, e a colocação de máquinas de venda automática ${ }^{16}$ se tornaram muito comuns. As escolas cedem aos avanços das empresas muito em razão das dificuldades financeiras enfrentadas (LINN, 2004; SIEGEL et al., 2001).

Essas influências trazem para perto das crianças uma série de marcas e produtos, oferecendo uma influência das empresas sobre temas que talvez devessem ser tratados de forma mais isenta (LINN, 2004). É importante, contudo, lembrar que iniciativas desse tipo ainda não são comuns no Brasil.

\footnotetext{
${ }^{16}$ Do inglês vending machines - tradução do autor.
} 
Este tópico abordou a questão da escola no processo de socialização do consumidor. A abordagem utilizada tratou das possibilidades da escola no sentido de educar as crianças a se tornarem melhores consumidores e as possibilidades de atuação das empresas dentro das escolas. A escola traz também a questão do convívio com outras crianças, mas este tema em específico será tratado posteriormente no item que abordará a influência dos pares ou colegas.

\subsubsection{Os pais}

Alguns autores avaliam que as relações entre pais e filhos passaram por drásticas mudanças nas últimas décadas (RIDEOUT, 2007; ROBERTS, 2007; BRÉE, 1995; NEELEY, 2005). Brée (1995) desenvolve essa idéia apresentando alguns fatores que podem explicar as razões que fundamentam essas mudanças ocorridas nas relações entre pais e filhos durante as últimas décadas:

- Os pais atuais foram educados em bases muito mais liberais que as gerações anteriores. Esses pais são frutos de novos valores e novas idéias que surgiram durante os anos 60 e 70. Entre as idéias que regem o comportamento destes pais, o autor destaca o individualismo e a valorização das posses materiais. O pesquisador também destaca uma maior participação da mulher no mercado de trabalho e maior participação dos homens nos afazeres domésticos. A questão religiosa também é analisada pelo autor, que considera que ocorreu uma diminuição das crenças religiosas. Por último, Brée (1995) acredita que estes pais apresentam certa insegurança e inquietude em relação ao futuro, assim como incertezas econômicas.

- O segundo item colocado pelo autor tem sua origem nas inúmeras fontes de informação às quais as crianças estão submetidas. Essa situação força os pais a terem um comportamento muito mais vigilante em relação àquilo que seus filhos são expostos. Por outro lado, os pais tornaram-se muito mais tolerantes em relação aos valores e ao comportamento dos seus filhos (BRÉE, 1995) 
As colocações de Brée (1995) permitem entender um pouco melhor o contexto que envolve a relação entre pais e filhos na atualidade. Neste mesmo diapasão, dados apresentados por Rideout (2007) indicam que, neste contexto, os pais estão extremamente preocupados com a influência que as informações transmitidas pelas diferentes mídias exercem sobre as crianças. Por exemplo, $52 \%$ dos pais norte-americanas estão, de alguma forma, preocupados com o conteúdo inapropriado que impacta seus filhos por meio das mídias existentes (ROBERTS, 2007).

Essa preocupação esclarece a necessidade dos pais serem mais vigilantes em relação aos hábitos de consumo de mídia dos seus filhos. Em famílias com um grau menor de instrução essa inquietação não é tão aparente, conforme explica Neeley (2005). A autora apresenta dados que indicam que famílias onde os pais têm um grau de instrução menor o consumo de mídia é maior, não sendo então uma questão importante para estes pais restringir a exposição dos seus filhos aos meios de comunicação.

Os pais têm um papel muito importante na socialização dos filhos (MOSCHIS, 1985), mas conforme atestam Ekstrom et al. (1987), os filhos também impactam de alguma forma as ações dos pais, talvez até ensinando-lhes coisas. Essa percepção pode ser trazida ao presente, visto que muitas vezes as crianças ou adolescentes conhecem algumas categorias de produto mais profundamente que os pais. Hawkins e Coney (1974), com base em um experimento realizado, especulam que as crianças têm um maior desejo por novidades, sendo assim, parece natural o fato de, em categorias de produtos relacionadas à tecnologia, existir uma maior predisposição das crianças em conhecer e se especializar nos produtos sendo lançados.

Parte do aprendizado da criança durante o processo de socialização como consumidora decorre dos padrões de comunicação intra-familiares (MOSCHIS e MOORE, 1981; MOSCHIS, 1985). As comunicações podem ser catalogadas como sendo

[...] sócio-orientadas, caracterizada por mensagens paternas direcionadas para promover deferência e para incentivar relações sociais harmoniosas e prazerosas entre pais e filhos; e orientadas para conceito, enfatizando restrições positivas que permitem que a criança desenvolva sua própria visão do mundo. (MOSCHIS e MOORE, 1981, p. 43). 
Esses dois padrões de comunicação geram uma tipologia de padrões da comunicação familiar (MOSCHIS e MOORE, 1981):

- Laizzez-faire: os pais não se engajam em comunicações sócio-orientadas ou orientadas para o conceito.

- Protetora: os pais destacam a importância da obediência e da harmonia social, demonstrando pouca preocupação com questões conceituais;

- Pluralísticos: encorajam a comunicação aberta e a discussão de idéias, sem insistir em obediência às autoridades, ou seja, a criança pode explorar novas idéias a expressa-las sem medo de reprimendas, existindo uma ênfase no respeito mútuo;

- Consensual: os pais incentivam ambos os tipos de comunicação e a criança é encorajada a tomar um interesse pelo mundo das idéias, desde que a hierarquia de opiniões e a harmonia interna não sejam perturbadas.

As colocações dos pesquisadores direcionam para a percepção da importância dos pais no processo de socialização, indicando que as comunicações intra-familiares podem ter um impacto significativo no desenvolvimento da criança como consumidora. Essa questão remete a reflexões sobre o papel dos pais como intermediadores do impacto da mídia na criança, sinalizando que a família pode funcionar como um grupo de interação onde as crianças podem construir uma visão mais crítica das funções positivas e negativas da mídia.

De acordo com Moschis (1985), a influência dos pais no processo de socialização pode ser direta ou indireta. A influência direta ocorre por meio dos processos de comunicação, incluindo interações sobre assuntos relacionados ao consumo, mecanismos de reforço e fornecendo oportunidade para que a criança observe o comportamento de consumo dos pais. A influência indireta acontece quando existem incentivos para que a criança seja exposta e participe de interações com outras fontes de influência, como por exemplo, a mídia televisiva. O autor aprofunda suas reflexões sobre o papel dos pais no processo de socialização reforçando a importância dos pais como mediadores dos efeitos de outros agentes socializantes sobre a criança. Essa influência será balizada pelo comportamento dos pais no cuidado com a criança, ou 
seja, o estilo que descreve o comportamento dos pais com a criança (CARLSON e GROSSBART, 1988).

Ward et al. (1977) apud Brée (1995, p.107) sugere algumas atitudes que os pais podem ter para ensinar aos seus filhos os rudimentos do consumo:

1. Proibir certos atos que parecem indesejáveis.

2. Dar classes formais sobre certos passos que devem ser seguidos durante o processo de consumo.

3. Manter conversações com as crianças com o objetivo de compreender melhor as decisões que eles mesmos tomam nas diversas circunstâncias.

4. Fazer-los participar em suas práticas como expectadores, quer dizer, multiplicar as observações a título de exemplo.

5. Outorgar autonomia cada vez maior para as crianças, autorizando-os a desenvolver suas próprias experiências.

Um ano mais tarde, Ward (1978) apresenta dados de uma pesquisa realizada com 615 crianças oriundas do jardim da infância (205 respondentes), terceira série (202 respondentes) e sexta série $^{17}$ (208 respondentes). $\mathrm{O}$ enfoque da pesquisa era o relacionamento das crianças com as mães e o impacto que esse relacionamento gera no aprendizado da criança. Após estudos, o autor indica que existem quatro tipos de variáveis independentes que influenciam esse aprendizado:

1. Variáveis relacionadas à interação mãe-filho: freqüência da negociação dos pedidos de compras feitos pelas crianças, freqüência das recusas com explicações, e flexibilidade nas respostas aos pedidos feitos.

\footnotetext{
${ }^{17}$ Do inglês kindergarten, third grade e sixth grade. Trazidos a realidade brasileira essas crianças devem apresentar respectivamente cerca de 6, 9 e 12 anos.
} 
2. Variáveis relacionadas ao comportamento de consumo da mãe: freqüência do uso de atributos contextuais na decisão de compra, efetividade relativa do uso de informações nas compras, e uso total de informações na compra.

3. Objetivos educacionais relacionados ao consumo e variáveis atitudinais: número de objetivos educacionais relacionados ao dinheiro e a qualidade da compra realizada

4. Variáveis relacionadas às oportunidades da criança: número de fontes distintas de dinheiro e renda total da criança.

É possível perceber, de forma resumida, que a criança apreende uma série de lições em função da forma como a mãe gerencia os pedidos feitos, como ela se comporta servindo de exemplo para a criança, como ela tenta ensinar ao seu filho e a renda disponível para a criança treinar o que aprendeu. $\mathrm{O}$ enfoque dado pelo autor, direcionando seu estudo para o papel da mãe, é resultado de uma característica peculiar da época, ou seja, o papel social da mãe. O aumento da participação da mulher no mercado de trabalho se torna significativo apenas na década de 80 (MCNEAL, 1992; 1999).

O impacto da mãe no aprendizado da criança muda de acordo com a idade. Crianças mais novas têm a interação com a mãe como fonte maior de aprendizado enquanto as mais velhas têm seu aprendizado explicado pelo comportamento da mãe (WARD, 1978). Esses resultados trazem importantes reflexões relacionadas a forma como a mãe deve se portar quando objetiva transmitir conhecimentos para seus filhos.

Moschis et al. (1984) abordam a questão da socialização do consumidor sob a ótica das técnicas de aprendizado utilizadas pelos pais. De acordo com os autores, os pais utilizam basicamente três técnicas diferentes: modelagem, interações sociais e reforço (positivo e negativo). Em seu estudo os autores buscaram identificar qual o impacto de cada uma dessas técnicas no processo de socialização do consumidor. Os resultados indicam que a maior parte do aprendizado é decorrente de observações feitas pelas crianças, ou seja, as crianças observam o comportamento 
dos pais e tentam imitar esse comportamento. Essa colocação decorre das baixas correlações identificadas entre (a) comunicação entre pais e filhos e (b) o conhecimento adquirido pelos filhos.

Neeley (2005), abordando a questão das relações entre pais e filhos no novo milênio, indica que mudanças culturais tiveram um impacto bastante significativo nas relações familiares. Esse impacto cria uma situação onde as crianças mais novas são podadas nas suas decisões e as crianças mais velhas são alvo de discussões centradas nos aspectos inerentes ao consumo e são encorajadas a tomarem decisões. Essas discussões com crianças mais velhas são centradas na transmissão de conceitos relacionados ao consumo e que são considerados como importantes pelos pais.

A atuação dos pais como educadores da criança no seu papel de consumidora é mediado por diversos fatores socioeconômicos, conforme explica Neeley (2005):

- Pais com uma formação melhor (nível universitário) consomem menos mídia, são mais críticos em relação à propaganda e realizam atividades conjuntas de consumo em quantidade superior a pais com uma formação menor ( $2^{\circ}$ grau $)$.

- Os pais com uma formação menor estão mais expostos à mídia, são menos reticentes aos impactos da propaganda e não realizam tantas atividades conjuntas de consumo.

As atividades de consumo relatadas são momentos onde os pais utilizam uma determinada oportunidade de consumo para orientar seus filhos no desenvolvimento como consumidor. A autora nota, no entanto, que as filhas são alvo de um maior número de oportunidades de experimentar ocasiões de consumo em companhia das mães, retratando ainda alguns indícios de uma realidade que é cada vez menos comum. Essa situação cria um segmento de filhos que não têm o mesmo preparo, tornando-os parcialmente incapacitados como consumidores (NEELEY, 2005). Dessa forma, seria natural encontrar diferentes níveis de socialização de acordo com o gênero. É possível entender que essa situação traz impactos importantes para empresas que 
pretendem oferecer o mesmo produto para ambos os sexos, tendo em vista que o gênero feminino estará mais adiantado no seu processo de socialização.

A relação de mães e filhas no contexto do consumo é abordada por Moore-Shay e Lutz (1988). O estudo em questão parte da suposição de que a existência de similaridades entre (1) preferências de marca, (2) regras de decisão e (3) crenças sobre o mercado sinalizam a existência de uma transferência de conhecimento entre a mãe e a filha. Os resultados apresentados indicam que preferências de marca e regras de decisão são fatores que são compartilhados entre mães e filhas, assim como existe um alto grau de conhecimento entre as duas pessoas sobre as respectivas preferências.

Com relação às crenças sobre o mercado, os resultados não permitem indicar uma transferência de conhecimento, o que pode ser entendido como uma falha na transmissão de conhecimentos mais abstratos (MOORE-SHAY e LUTZ, 1988). Esta última consideração é analisada pelos autores, os quais consideram que as crianças podem ter uma maior facilidade para observar fatos concretos, como preferências de marcas e estratégias de compras (regras de decisão), em oposição a fatos abstratos como crenças sobre o mercado. A pesquisa foi realizada com jovens oriundas da universidade, trazendo algumas limitações para as considerações aqui feitas. De qualquer forma, os resultados apresentados permitem compreender o impacto da mãe num momento mais avançado do processo de socialização. No entanto, pesquisas com filhas inseridas na faixa etária que configura o mercado infantil seriam necessárias para uma melhor compreensão deste fenômeno.

As maiores diferenças entre as percepções das mães e filhas sobre o mercado aparecem quando são questionadas a respeito da relação preço-qualidade (as mães são mais descrentes) e confiança nas propagandas (as mães são mais céticas) (MOORE-SHAY e LUTZ, 1988). É possível relacionar estes resultados de pesquisa ao processo de desenvolvimento da criança ou adolescente, talvez com o amadurecimento as pessoas se tornem mais céticas em relação à propaganda e à avaliação preço-qualidade em função de experiências negativas acumuladas concernindo estes dois fatores. 
McNeal (1992) traz um enfoque diferente para o relacionamento entre os pais e as crianças. Ele trabalha esse aprendizado analisando as oportunidades de interação entre a criança, os pais e algum ambiente de varejo. Para o autor, o desenvolvimento da criança como consumidora ocorre por meio de uma série de etapas que a criança percorre junto aos pais. A seguir as etapas são apresentadas:

1. Acompanhando os pais e observando: a partir do momento em que a criança consegue sentar, ela é colocada no topo de um carrinho de supermercado. A partir desse ponto de observação culturalmente definido, a criança passa a acompanhar o movimento dos pais e de outros consumidores em locais como o supermercado. Logo a criança reconhece que as instituições do varejo, como supermercados, hipermercados e lojas de conveniência, estão estocadas com coisas boas de comer e de brincar - de fato, coisas que os pais utilizam para recompensar alguma ação ou demonstrar amor. Somente ao se aproximar dos dois anos, a criança passa a fazer algumas poucas conexões entre o que vê nas lojas com as propagandas televisivas.

2. Acompanhando os pais e requisitando: a partir dos dois anos de idade as requisições feitas em lojas de varejo tem início. O aumento do número de visitas ao varejo, o maior consumo de determinados produtos (comida e brinquedos) e uma maior atenção às propagandas durante a programação televisiva produzem um aumento na lista de coisas que as crianças desejam. Ao mesmo tempo, o infante começa a aprender os caminhos para fazer com que os pais respondam positivamente aos seus pedidos ${ }^{18}$. Dependendo da forma como o pedido é feito, o sentimento de vergonha que os pais podem sentir dentro de um supermercado pode gerar percepções negativas em relação à disciplina de marketing. Os pais podem considerar que a criança está sendo influenciada pelas propagandas a fazer pedidos de forma tão vigorosa (chorando, gritando, etc.). Este período, quando a criança faz pedidos, é de grande aprendizado, pois a criança passa a entender as

\footnotetext{
18 Para maiores referências com relação a estratégias de convencimento ver Marquis (2004) e Bridges e Briesch (2006).
} 
situações e, com base nisso, passa a criar alguns scripts mentais que a ajudam a entender melhor o seu papel como consumidora e os locais mais adequados para determinados pedidos.

3. Acompanhando os pais e selecionando produtos com permissão: a partir dos três ou quatro anos de idade as crianças deixam seu posto de observação no topo do carinho de supermercado para andar livremente pelo ambiente de varejo. Nesse momento, a influência da criança sobre as decisões de compra cresce consideravelmente, conforme demonstram Veloso e Hildebrand (2006) e Veloso et al. (2008). De acordo com os autores, por volta dessa idade a criança passa a ajudar os pais na escolha dos produtos e também coloca produtos no carrinho do supermercado sem autorização. Durante este período, acrescente McNeal (1992), as crianças passam a ter marcas favoritas para algumas categorias de produto, passam a ter a liberdade de ajudar os pais nas compras (seja para ficarem ocupadas ou para que aprendam os rudimentos do processo de consumo). $\mathrm{O}$ autor finaliza indicando que é nesse período que o entendimento do processo de necessidadesatisfação, característica de uma sociedade de consumo, se inicia.

4. Acompanhando os pais e fazendo compras independentes: durante esta fase a criança começa a realizar suas próprias compras na companhia dos pais. Esta situação tem uma conotação de ensinamento, ou seja, os pais realizam esforços para ensinar a criança como comprar coisas (escolha, pagamento, etc) (VELOSO e HILDEBRAND, 2006; VELOSO et al., 2008). Nesta etapa, aparecem problemas relacionados ao entendimento do processo de troca (dinheiro por mercadorias) e a matemática do dinheiro. Também, aparecem questões relacionadas ao próprio funcionamento do sistema (esperar em filas, ser atendido pelo caixa, indiferença de funcionários da loja). A cada nova experiência de consumo, a criança vai angariando informações que vão lhe trazer um melhor entendimento de todo o contexto envolvido no processo de compra. 
5. Indo para a loja sozinha e fazendo compras independentes: entre os cinco e sete anos a criança passa a atuar como um consumidor no sentido mais amplo da palavra. Ela vai sozinha até o ambiente onde realizará a compra, escolhe ou requisita os produtos que deseja, paga por eles e os leva. De forma geral, essas primeiras compras são realizadas em lojas de conveniência e têm como alvo categorias de produto mais próximas da criança, como refrigerantes ou salgadinhos. Também são freqüentes as visitas à padaria para comprar leite e pão ${ }^{19}$. Nesses primeiros momentos, a criança apresenta uma grande excitação em realizar esse tipo de operação sozinha. Esses acontecimentos podem ter um papel muito grande nas atitudes de uma criança com relação a determinadas lojas. Lojas que receberem bem as crianças nesses primeiros momentos como consumidora terão chances maiores de ser alvo de uma predileção especial no futuro.

Como pode ser visualizado nas explicações de McNeal (1992; 1999), a interação das crianças com os pais pode ser entendida como uma das relações agente-aprendiz apresentadas anteriormente na Ilustração 11. Os relacionamentos ocorridos durante os momentos de consumo podem ser visto como fontes de exemplos, ou seja, eles mostram como a criança ou adolescente deve se conduzir.

De acordo com Moschis et al. (1984), os pais conseguem transmitir exemplos que são corretamente imitados pelos filhos, mas estes mesmos pais falham ao explicar as razões que justificam esse comportamento. Isso indica que o papel dos pais está mais focado em mostrar o que eles consideram como o comportamento correto, do que em tentar explicar as razões que justificam esse comportamento. Uma explicação para esse fenômeno pode decorrer das dificuldades em elucidar a uma criança as razões para alguns tipos de comportamento de consumo, por exemplo, é possível imaginar as dificuldades de um pai ao esclarecer as razões que o levam a priorizar determinada loja ou marca.

O papel dos pais na socialização dos seus filhos também se apresenta como importante no momento de oferecer reforço positivo para ações consideradas apropriadas (MOSCHIS et al.,

\footnotetext{
${ }^{19}$ Do inglês bread and milk runs.
} 
1984). Com o passar dos anos e com a chegada da adolescência, diminui o impacto dos pais nesse processo (MOSCHIS et al., 1984). Percebe-se, ao analisar os dados apresentados pelos autores, que o papel dos pais tem uma importância preponderante durante a infância. Com a chegada da adolescência, cresce a importância dos colegas neste processo de aprendizado.

Ao longo deste tópico foram abordados os trabalhos que tratam do impacto dos pais no processo de socialização do consumidor. Foi possível compreender que os pais podem atuar como modelos ou de forma mais importante educando a criança. Diferenças entre o processo de socialização do gênero masculino e feminino foram identificadas, assim como o impacto do tipo de comportamento dos pais, seja em função do seu perfil, ou em função do seu nível socioeconômico.

\subsubsection{Os colegas}

Os grupos de colegas, ou semelhantes, exercem influência semelhante àquela exercida pelos pais, tendo um papel muito importante na construção de preferências por produtos e padrões de consumo, desde que a categoria seja relevante para o grupo (HAWKINS e CONEY, 1974). Ford e Ellis (1980), ao replicar o experimento conduzido por Stafford (1966), concluem que a influência do grupo não é relevante para produtos com baixa visibilidade, complexidade, risco percebido e alto nível de experimentação.

Os comentários dos autores acima permitem visualizar o impacto do grupo como mais relevante para produtos que serão vistos e comentados pelos outros. Essa situação remete ao processo de construção do auto-conceito. Levy (1959) trouxe a tona, no fim da década de 50, a questão das marcas e símbolos como forma de transparecer o auto-conceito que a pessoa idealiza, ou seja, "as pessoas compram coisas não somente pelo que elas podem fazer, mas também pelo que elas significam" (LEVY, 1959, p. 118). Esse significado que as marcas assumem, por meio das posses, pode ser consciente ou inconsciente (BELK, 1988). Assim, a identificação que o indivíduo estabelece com suas posses começa a acontecer na infância, tanto quando a criança passa a se perceber como diferente das outras, quanto quando a inveja pelas suas posses se torna evidente por parte de outras crianças (BELK, 1988). 
De acordo com Chaplin e John (2005), o desenvolvimento do número de conexões entre as crianças e as marcas cresce com a idade. Crianças entre 7 e 8 anos apresentam um número menor de conexões entre seu auto-conceito e as marcas, caso comparadas com indivíduos entre 12 e 13 anos. Os autores elucidam algumas possibilidades para explicar esse fenômeno. Com o aumento da idade, muda a natureza das relações que a criança constrói com a marca. Crianças com uma idade superior criam conexões entre o seu auto-conceito e as marcas de forma mais profunda, isso acontece porque essas crianças percebem as marcas como tendo uma imagem, além de a marca simbolizar a relação da criança com o grupo a qual ela deseja pertencer, sempre em consonância com seu auto-conceito (CHAPLIN e JOHN, 2005).

Sabendo que o auto-conceito é construído por meio de conexões cognitivas estabelecidas entre os estímulos captados do ambiente, que juntos compõe a identidade dos indivíduos, objetos, produtos, etc. (WHETTEN e GODFREY, 1998; BATTACHARYA e SEN, 2003), é de se esperar que ambos os fenômenos descritos por Chaplin e John (2005) evoluam acompanhando o desenvolvimento cognitivo da criança.

Escalas e Bettman (2005) discutem a questão das marcas e dos grupos de convívio social salientando que o significado das marcas emerge do grupo. Dessa forma, torna-se clara a importância da chegada dos anos escolares no processo de desenvolvimento da criança como consumidora. Ao começar a fazer parte de um novo grupo de convivência, a criança passa a ser exposta a uma nova gama de significados e informações. Além dessa maior exposição ao grupo, a criança também passa a ter mais experiências com as marcas e maior exposição às campanhas de marketing voltadas à construção de valor de marca (CHAPLIN e JOHN, 2005). Neste contexto, é possível entender a participação das marcas como um moderador da relação da criança com o grupo, pois é por meio das marcas a criança busca sua inserção nos aglomerados.

Enquanto parte de um grupo, a criança está exposta a um nível maior de influência quando existe coesão e algum tipo de liderança no grupo (STAFFORD, 1966). O autor coloca que a importância do líder é bastante clara, sendo ele o responsável por grande parte das escolhas. A coesão permite a emergência de lideres informais, que também passam a influenciar as outras 
crianças. $\mathrm{O}$ autor finaliza ressaltando que, quanto maior for a lealdade do líder a alguma marca, maior será a lealdade do grupo a esta marca em particular. Essa situação traz importantes recomendações para os profissionais de marketing, pois é possível trabalhar ações que visem crianças que são consideradas como lideres entre seus pares.

Lindstrom e Seybold (2003) apresentam uma série de sugestões para potencializar o sucesso de um lançamento com base na questão do líder do grupo e sua influência. Os autores sugerem que as empresas busquem os lideres das comunidades e criem programas de marketing que os incentivem a direcionar o grupo para a compra de determinado produto. Ainda de acordo com os autores, é possível trabalhar a questão do marketing viral e os lideres de comunidades de forma conjunta, explorando a capacidade do líder da comunidade como facilitador das comunicações do grupo para transmitir mensagens oriundas das empresas.

Ressalva-se, contudo, que as ações de marketing anteriormente descritas são passíveis de inúmeras críticas, sendo necessário uma cuidadosa análise dos limites éticos que devem ser respeitados pelos profissionais de marketing.

A importância do grupo também aparece com relação às marcas escolhidas pelos participantes (ESCALAS e BETTMAN, 2005). Marcas que são consistentes com a imagem que os integrantes do grupo imaginam transmitir são mais aceitas do que marcas que apresentam um nível baixo de congruência. Estudos que tratassem da formação de um auto-conceito grupal poderiam trazer mais informações para este foco de discussão.

Tendo colocado a importância do grupo como fator influenciador, se torna necessário abordar como esse processo ocorre. Nesse sentido as colocações de Moreno e Cubero (1995, p.256) trazem informações relevantes: "[a] grande importância que os iguais exercem sobre o desenvolvimento da criança é realizado por mecanismos semelhantes aos utilizados pelos adultos: reforço, modelagem e ensino direto." Os psicólogos sociais continuam afirmando que os iguais, ou colegas, cumprem funções similares àquelas cumpridas pelos pais, como a criação de laços de apego ou a busca de apoio em situações de ansiedade. 
Nesse sentido, a relação entre as crianças é caracterizada por ser uma relação entre iguais, ou seja, uma relação diferente da relação assimétrica que existe entre as crianças e os pais. Dessa forma, a relação entre as crianças é caracterizada por Moreno e Cubero (1995, p. 257) como sendo uma relação baseada "[...] na igualdade, na cooperação e na reciprocidade entre sujeitos que possuem destrezas semelhantes." Percebe-se aqui que a relação da criança com os seus pares, e a relação da criança com seus pais, apresentam algumas semelhanças (MORENO e CUBERO, 1995; HAWKINS e CONEY, 1974).

Os contatos que existem entre as crianças e seus semelhantes podem acontecer tanto entre colegas oriundos da escola, como entre filhos de amigos dos pais ou entre irmãos. A chegada de um irmão numa família se caracteriza por uma mudança no sistema previamente estabelecido, ou seja, as relações familiares se transformam para se adequar à nova realidade (MORENO e CUBERO, 1995). Quando os irmãos são do mesmo sexo, existe a tendência de ocorrer um maior número de interações e imitações mútuas de comportamento. A questão da diferença de idade também é levantada pelos autores, sendo que quanto menor for essa diferença, maior a chance de existir uma sobreposição de habilidades, interesses e amigos, gerando um potencial de conflito e rivalidade maior.

A chegada dos anos escolares traz uma nova realidade para a criança, o contato com os professores, o ambiente da escola e o contato com os colegas. Neste tópico, o enfoque será dado para o início de um contato mais próximo com os iguais. Moreno e Cubero (1995) analisam o desenvolvimento da criança e o tamanho dos grupos com as quais a criança interage. Conforme a criança avança pelos anos escolares, aumenta o número de crianças envolvidas nos grupos, sendo que o indivíduo passa de relações primordialmente diádicas, para relações grupais. A convivência em grupo impõe à criança uma série de exigências: aumento da competência comunicativa, coordenação de intenções, etc. Essas mudanças trazem importantes reflexões para a área de marketing, principalmente para o desenvolvimento de produtos que exigem um determinado número de participantes. A empresa deve atentar para a capacidade da criança em realizar atividades de grupo ao desenvolver produtos para cada uma das faixas etárias. 
Duncan et al. (2001) analisam a influência dos diferentes tipos de pares (irmãos, amigos, colegas de sala e vizinhos) no comportamento e nas realizações das crianças, indicando que os irmãos são responsáveis pelo maior nível de influência. Os resultados apresentados pelos autores focam em questões relacionadas com o desenvolvimento escolar da criança (desempenho em testes variados) e com o envolvimento em ações de delinqüência. Transportar os resultados diretamente para o ambiente de consumo talvez não seja possível, mas de qualquer forma, abre-se aqui um novo caminho de pesquisa que poderia ser abordados dentro da área de marketing. Esses esforços poderiam focar a influência dos diferentes tipos de grupos na escolha de marcas, no comportamento de consumo, na preferência por lojas, etc..

A questão dos colegas foi abordada dando primazia para os estudos que tratam das relações entre indivíduos, com destaque para as ligações cognitivas entre juvenis, procurando demonstrar a necessidade de uma atenção especial por parte da empresa no lançamento de produtos que exigem a participação de mais uma criança. Também foram abordados trabalhos que tratam das relações grupais, e como essas relações impactam a criança. Interessante notar que a relação da criança com o grupo assume algumas características similares à relação da criança com os pais, principalmente quando aborda-se o reforço e modelagem do comportamento. Empresas focadas no consumidor infantil devem buscar a aceitação dos pais em alguns casos e do grupo em outros casos, dependendo da faixa etária atendida.

\subsubsection{Variáveis de segmentação - nível de desenvolvimento da criança}

Este tópico aborda estudos que tratam de ferramentas para avaliar o nível de desenvolvimento da criança ao longo do processo de socialização. O tópico é pertinente a medida que fornece alguns direcionamentos para que se possam conduzir estudos para identificar o nível de socialização de determinado segmento etário. Também traz como aporte, a sinalização dos fatores que são mais importantes no processo de socialização e que merecem atenção das empresas e dos pesquisadores.

Moschis e Moore (1978) sugerem alguns itens por meio dos quais seria possível determinar se o indivíduo está adquirindo as competências necessárias para se tornar um "bom consumidor" - 
conhecimento das marcas, conhecimento dos preços, conhecimento de aspectos legais e concepções dos papeis como consumidor.

Reece e Kinnear (1986) desenvolveram escalas para medir o desenvolvimento da criança como consumidora no contexto do varejo. Os autores indicam que o conhecimento da criança pode ser medido a partir de dois fatores: (1) habilidades como compradora (shopping skills) e conhecimento sobre como uma loja de varejo funciona (store operations).

Quadro 8 - Indicadores do desenvolvimento da criança como consumidora no contexto do varejo

\begin{tabular}{|l|l|}
\hline $\begin{array}{l}\text { Componentes do Índice de Habilidades como } \\
\text { Compradora }\end{array}$ & $\begin{array}{l}\text { Componentes do Índice Conhecimento Sobre Como } \\
\text { uma Loja de Varejo Funciona }\end{array}$ \\
\hline $\begin{array}{l}\text { Habilidade em descrever uma ida a uma: } \\
\text { - Mercearia } \\
\text { - Loja de Departamentos }\end{array}$ & $\begin{array}{l}\text { Habilidade em relacionar produtos com os tipos de } \\
\text { lojas }\end{array}$ \\
\hline Habilidade em nomear os métodos de pagamento & Habilidade em nomear lojas de diferentes tipos \\
\hline Habilidade em manejar problemas ocorridos na compra & Habilidade em nomear atributos que afetam a lealdade \\
\hline Habilidade em relacionar produtos e departamentos & Habilidade em nomear funcionários da loja \\
\hline $\begin{array}{l}\text { Consciência sobre as formas alternativas de um } \\
\text { produto }\end{array}$ & Habilidade em descrever as funções de um vendedor \\
\hline $\begin{array}{l}\text { Habilidade em fazer comparações de quantidade e } \\
\text { preço }\end{array}$ & Conhecimento sobre quem é proprietário da loja \\
\hline Consciência sobre datas de validade & Consciência sobre as fontes de merchandising \\
\hline
\end{tabular}
FONTE: Adaptado de REECE e KINNEAR; 1986, p. 274 e 276.

Para desenvolver a escala, Reece e Kinnear (1986) coletaram dados com 129 crianças. Essas crianças eram provenientes pré-escola (6 anos), da terceira série ( 9 anos) e da sexta série (12 anos). As crianças da pré-escola tiveram que responder o questionário por meio de entrevistas, em função da incapacidade de ler. Os autores finalizam seu trabalho indicando que os indicadores de confiabilidade e de validade de conteúdo foram satisfatórios, criando assim a base para o desenvolvimento de outros trabalhos com enfoque similar.

Os itens apresentados por Reece e Kinnear (1986) permitem esclarecer algumas das variáveis que devem ser avaliadas para compreender melhor os estágios do desenvolvimento da criança como consumidora. Estas sinalizam o que a literatura desenvolvida até então entendia como relevante para o desenvolvimento do consumidor. As mudanças tecnológicas, culturais (NEELEY, 2005) e de formatos de lojas podem ter impactado quais os itens que devem fazer parte deste índice, exigindo assim estudos mais aprofundados tomando como base o contexto atual. 
Lueg e Finney (2007) abordam o contexto das compras realizadas em shopping centers e pela internet, buscando desenvolver uma escala que possa medir o impacto das comunicações interpessoais no processo de socialização do consumidor. O estudo dos autores é baseado numa amostra de 1258 estudantes do segundo grau. A escala tem como objetivo identificar qual o impacto dos pais e dos colegas na socialização do consumidor. Os resultados alcançados estão direcionados ao desenvolvimento da escala e não à verificação do nível de impacto dos grupos mencionados no adolescente. Os pesquisadores indicam que o instrumento deveria ter sido aplicada de forma longitudinal, para medir de forma mais correta os impactos ao longo do tempo. De qualquer forma, trata-se de um instrumento que pode ser utilizado por empresas ou estudiosos que buscam verificar, longitudinalmente, como o processo de socialização é impactado pelos colegas e pelos pais.

Stephens e Moore (1975) trabalham a questão do conhecimento do preço dos produtos como indicador do nível de desenvolvimento da criança. A variável independente - conhecimento de preço - seria resultante de uma série de variáveis dependentes:

- Status socioeconômico

- Inteligência

- Gastos semanais

- Comunicações familiares sobre o consumo

- Tempo de exposição à televisão

- Tempo de exposição a jornais

- Utilidade da comunicação (uso de comerciais como assunto para conversação)

- Consumo vicário (o prazer relacionado ao consumo)

- Utilidade social (como as propagandas influenciam a percepção dos outros sobre o indivíduo e como os comerciais apresentam estilos de vida que podem ser almejados pelo receptor)

A pesquisa conduzida por Stephens e Moore (1975) foi realizada com dois grupos diferentes de crianças. O primeiro grupo foi composto por crianças no final do $1^{\circ}$ grau (entre 12 e 15 anos) e o segundo grupo por crianças do $2^{\circ}$ grau (entre 16 e 19 anos). Os resultados encontrados clarificam 
as variáveis que influenciam o conhecimento de preço, a citar: $1^{\mathrm{o}}$ grupo - gastos semanais, comunicações familiares sobre o consumo; $2^{\circ}$ grupo - comunicações familiares sobre o consumo e exposição à mídia. A partir desses resultados, percebe-se a importância da família no momento de transmitir informações para as crianças, possibilitando que as mesmas se desenvolvam no processo de socialização, tendo então um maior conhecimento dos preços dos produtos.

O desenvolvimento da criança como consumidora também pode ser medido por meio de variáveis como (MOSCHIS et al., 1984):

- Conhecimento de assuntos ligados ao consumo: esta variável mede o conhecimento da criança sobre os principais conceitos ligados ao consumo e à legislação que rege as relações entre as empresas e os consumidores.

- Atividades de consumo: esta variável mede a freqüência e a habilidade da criança em comprar e usar diferentes produtos e serviços de forma racional e eficiente.

- Percepção dos papéis associados ao consumo: esta variável mede o conhecimento da criança sobre as funções do consumidor, seus direitos e obrigações.

A seguir, é apresentado o Quadro 9, onde John (1999) resume a teoria desenvolvida ao longo de 25 anos de pesquisa no campo da socialização do consumidor. 
Quadro 9 - Estágios da socialização do consumidor

\begin{tabular}{|l|l|l|l|}
\hline \multicolumn{1}{|c|}{ Características } & \multicolumn{1}{|c|}{$\begin{array}{c}\text { Estágio Perceptual: } \\
\text { 3-7 anos }\end{array}$} & \multicolumn{1}{c|}{$\begin{array}{c}\text { Estágio Analítico: } \\
\text { 7-11 anos }\end{array}$} & $\begin{array}{c}\text { Estágio Reflexivo: } \\
\text { 11-16 anos }\end{array}$ \\
\hline Estruturas de conhecimento & Concreta & Abstrata & Abstrata \\
\hline Orientação & $\begin{array}{l}\text { Características } \\
\text { perceptuais }\end{array}$ & $\begin{array}{l}\text { Características } \\
\text { funcionais / subjacentes }\end{array}$ & $\begin{array}{l}\text { Características } \\
\text { funcionais / subjacentes }\end{array}$ \\
\hline Foco & $\begin{array}{l}\text { Unidimensional } \\
\text { Simples }\end{array}$ & $\begin{array}{l}\text { Duas ou mais dimensões } \\
\text { Contingente (“ Se - } \\
\text { Isso") }\end{array}$ & $\begin{array}{l}\text { Multidimensional } \\
\text { Contingente (“ Se - } \\
\text { Isso") }\end{array}$ \\
\hline Complexidade & Egocêntrica & $\begin{array}{l}\text { Perspectiva dual } \\
\text { (própria + outros) }\end{array}$ & $\begin{array}{l}\text { Perspectiva dual num } \\
\text { contexto social }\end{array}$ \\
\hline Perspectiva & \multicolumn{3}{|l|}{} \\
\hline Processo de Decisão e estratégias de influência & Oportuna & Atenciosa & Estratégica \\
\hline Orientação & $\begin{array}{l}\text { Características } \\
\text { perceptuais } \\
\text { Características } \\
\text { Foco }\end{array}$ & $\begin{array}{l}\text { Características } \\
\text { funcionais / subjacentes } \\
\text { Características } \\
\text { relevantes }\end{array}$ & $\begin{array}{l}\text { Características } \\
\text { funcionais / subjacentes } \\
\text { Características } \\
\text { relevantes }\end{array}$ \\
\hline Complexidade & $\begin{array}{l}\text { Atributos simples } \\
\text { Repertório limitado de } \\
\text { estratégias }\end{array}$ & $\begin{array}{l}\text { Dois ou mais atributos } \\
\text { Repertório expandido de } \\
\text { estratégias }\end{array}$ & $\begin{array}{l}\text { Múltiplos atributos } \\
\text { Repertório completo de } \\
\text { estratégias }\end{array}$ \\
\hline Adaptatividade & Emergente & Moderado & $\begin{array}{l}\text { Totalmente } \\
\text { desenvolvida }\end{array}$ \\
\hline Perspectiva & Egocêntrica & $\begin{array}{l}\text { Perspectiva dual num } \\
\text { contexto social }\end{array}$ \\
\hline
\end{tabular}

FONTE: JOHN; 1999, p.186.

O quadro apresentado por John (1999) resume a importância deste tópico para este trabalho. Com base nas considerações da autora, é possível compreender melhor o impacto da idade nas capacidades da criança no que se refere ao seu relacionamento com o consumo. $\mathrm{O}$ infante apresenta profundas diferenças de conhecimento e de processo de decisão, diferenças estas que fazem emergir profundas adaptações nas estratégias de uma empresa que foca no mercado infantil.

\subsubsection{Pesquisa de segmentação e o consumidor infantil}

"Pesquisando o mercado infantil: trabalho duro, resultados questionáveis" (MCNEAL, 1999, p.231). A frase do autor simboliza as dificuldades de se realizar pesquisas com o consumidor infantil, dificuldades que serão abordadas neste tópico do trabalho. "Mais de $90 \%$ das marcas destinados às crianças falham" (VECCHIO, 2002, p. 217). Já esta segunda frase sinaliza a importância da realização de pesquisas. A pesquisa de mercado junto ao segmento infantil é algo 
difícil, trabalhoso, que apresenta inúmeras dificuldades, mas que deve ser realizado, pois aumenta as chances de sucesso da empresa (VECCHIO, 2002; MCNEAL,1992).

Os novos lançamentos de produtos ou marcas falham porque muitas vezes a empresa não conduziu nenhum tipo de pesquisa antes da introdução do produto no mercado (MCNEAL, 1992). Naquela época, o autor também indicava que mesmo as empresas que faziam pesquisas, o faziam de forma equivocada, criando situações de teste de produto não realísticas, contaminadas pela presença de adultos.

Vécchio (2002) insere a questão da pesquisa no processo de lançamento de novos produtos e melhorias nos produtos existentes. Além disso, complementa o autor, é possível utilizar a pesquisa como insumo para a elaboração de planos de marketing.

A pesquisa com crianças certamente é um dos temas mais complicados para os estudiosos e profissionais de marketing envolvidos com o mercado infantil. Isso decorre das diferentes capacidades que a criança exibe no decorrer do seu desenvolvimento, dificultando a coleta de dados confiáveis e exigindo extremo cuidado dos profissionais de marketing ou acadêmicos quando conduzindo pesquisas junto a este público. Esta questão se torna ainda mais sensível para uma empresa conduzindo uma pesquisa de segmentação junto a um grupo de crianças. Resultados enganadores podem ser desastrosos para a empresa.

Inicialmente, poucas empresas destinavam recursos para a pesquisa de mercado junto ao consumidor infantil (MCNEAL, 1992). Alguns anos depois, McNeal (1999) ressalta que as primeiras empresas que decidiram por adaptar produtos para crianças, ou lançar novos produtos para esse público, optaram por realizar elas mesmas suas pesquisas. De acordo com o autor, o fato ocorreu tanto porque as empresas queriam economizar recursos e manter um segredo competitivo dos seus achados, quanto, principalmente, porque poucas empresas de pesquisa estavam preparadas para realizar pesquisas junto a este público. $O$ autor reconhece que, atualmente, essa realidade não é mais verdadeira, pelos menos para o mercado norte-americano, já que existem inúmeras empresas de pesquisa especializadas neste grupo de consumidores. McNeal (1999, p.236-239) tece algumas considerações ainda e sugere algumas formas de diminuir os potenciais erros no processo de pesquisa junto ao consumidor infantil: 


\begin{tabular}{|c|c|}
\hline Sugestões & Explicação \\
\hline $\begin{array}{l}\text { Fale por meio de } \\
\text { figuras/desenhos } \\
\text { quando for possível }\end{array}$ & $\begin{array}{l}\text { Cerca de } 2 / 3 \text { dos estímulos chegam até o cérebro por meio do sistema visual, e para crianças esse percentual é ainda maior. Dessa } \\
\text { forma, crianças, particularmente aquelas que têm idade inferior a } 9 \text { anos, possuem um amplo vocabulário verbal e visual. Técnicas } \\
\text { de pesquisa que utilizam esses códigos visuais podem ser tão efetivas quanto técnicas que utilizam códigos verbais, enquanto evitam } \\
\text { alguns dos problemas de linguagem que podem ocorrer. O uso de estímulos visuais pode tomar a forma de fotos ou figuras sobre } \\
\text { lojas, produtos, marcas ou embalagens que são mostradas para as crianças, tanto para ajudar na compreensão de uma questão como } \\
\text { para estimular uma resposta. O pesquisador pode pedir respostas por meio da escolha de desenhos pré-elaborados, ou até mesmo na } \\
\text { forma de um desenho feito pela criança. Os desenhos são adequados para coletar percepções sobre marcas, preços, lojas etc. }\end{array}$ \\
\hline $\begin{array}{l}\text { Não trabalhe além dos } \\
\text { seus limites de } \\
\text { conhecimento }\end{array}$ & $\begin{array}{l}\text { As crianças têm um nível de conhecimento limitado às suas experiências. Apesar de crianças de } 8 \text { anos poderem conduzir uma boa } \\
\text { conversa, elas só poderão manter essa conversação sobre um pequeno número de tópicos extraídos de seu relativo pequeno mundo. } \\
\text { Pode acontecer de a criança tentar transparecer que sabe sobre determinado tema para que pareça pertencer ao mundo adulto. Cada } \\
\text { palavra e tópico de um questionário deve ser alvo de um pré-teste em crianças da idade almejada na coleta de dados. A capacidade } \\
\text { de leitura e o conhecimento relacionado ao tema também devem ser analisados. }\end{array}$ \\
\hline $\begin{array}{l}\text { Não peça às crianças } \\
\text { muito raciocínio }\end{array}$ & $\begin{array}{l}\text { As crianças podem oferecer respostas às perguntas do pesquisador, mas pode não ter muita idéia do que está respondendo, } \\
\text { entregando ao pesquisador aquilo que ela acha que se espera dela, sem realmente raciocinar sobre sua resposta, principalmente para } \\
\text { crianças abaixo dos } 9 \text { ou } 10 \text { anos. A sugestão é: peça respostas, não raciocínio. Crie opções bem desenhadas e peça para que a } \\
\text { criança escolha uma delas, esse tipo de estratégia de pesquisa terá maiores chances de sucesso. }\end{array}$ \\
\hline $\begin{array}{l}\text { Não tenha medo de ser } \\
\text { criativo com os } \\
\text { métodos de pesquisa de } \\
\text { mercado }\end{array}$ & $\begin{array}{l}\text { Essa sugestão pode não ser muito cientifica, mas ainda não se sabe muito como conduzir pesquisa com crianças. Por exemplo, cerca } \\
\text { de } 50 \% \text { das crianças entre } 5 \text { e } 10 \text { anos apresenta algum nível de timidez, tímidas até o ponto de não responder as questões. Questões } \\
\text { pessoais ativam um nível ainda maior de timidez, principalmente quando feitas por um adulto não familiar à criança. Até o momento } \\
\text { ainda não se descobriu como diminuir o impacto desse fenômeno, mas com certeza isso só será feito por meio de técnicas de } \\
\text { pesquisa criativas. Uma possibilidade é gravar as questões numa fita e pedir para que as crianças respondam sozinhas. Outra forma é } \\
\text { utilizar meios digitais para fazer a pesquisa. Também é possível utilizar desenhos e pedir para que a criança comente sobre os } \\
\text { mesmos, como uma forma de técnica projetiva. }\end{array}$ \\
\hline $\begin{array}{l}\text { Não tenha medo de } \\
\text { substituir parentes por } \\
\text { crianças }\end{array}$ & $\begin{array}{l}\text { Incluir os pais como intermediários das informações sobre as crianças inclui mais um nível de distorção no processo de coleta de } \\
\text { dados, criando a chance para a ocorrência de um número maior de erros. Além disso, os pais podem introduzir erros ao não terem } \\
\text { uma correta percepção do que pensam seus filhos. Os pais podem até ter algum nível de conhecimento sobre alguns hábitos das } \\
\text { crianças, como gerenciamento do dinheiro, marcas favoritas de cereais e quando as crianças solicitam produtos, mas quando } \\
\text { questionados sobre assuntos que tratam de temas que poderiam gerar algum nível de critica ao seu próprio comportamento podem } \\
\text { responder com respostas socialmente desejáveis, buscando apenas aparecer bem para o pesquisador. Se casos como esses são } \\
\text { evitados os pais podem ser sim, fontes confiáveis de informações sobre as crianças. }\end{array}$ \\
\hline $\begin{array}{l}\text { Fale num vocabulário } \\
\text { que elas compreendam }\end{array}$ & $\begin{array}{l}\text { Não se pode esperar que as crianças falem como adultos, elas simplesmente ainda não tem essa capacidade. Mas também não adianta } \\
\text { ir buscar a gíria utilizada pelas crianças para se comunicar com elas, isso pode parecer exagerado ou inadequado na percepção delas. } \\
\text { O que deve ser feito é buscar o linguajar adequado para a faixa etária, buscando identificar o significado que elas dão às diferentes } \\
\text { palavras. Palavras vagas também devem ser evitadas. }\end{array}$ \\
\hline
\end{tabular}

FONTE: Adaptado de MCNEAL; 1999, p.236-239. 
Um dos grandes erros cometidos ao realizar pesquisas junto ao consumidor infantil, é tomar os métodos já utilizados junto aos adultos e adaptá-los aos consumidores juvenis. De acordo com o pesquisador, esse tipo de iniciativa parte do pressuposto errôneo de que a criança é um miniadulto. As técnicas de pesquisa devem ser idealizadas de acordo com a idade cronológica e o nível de maturidade psíquico e sociológico da criança (MCNEAL, 1999, VECCHIO, 2002). Vecchio (2002) analisa a questão da idade e afirma que crianças abaixo dos 5 anos não têm capacidade para se expressar corretamente, limitação decorrente da timidez ou da falta de vocabulário, exemplificando alguns dos problemas que podem ocorrer durante a pesquisa.

Acrescentado a suas contribuições no campo, McNeal (1999) realiza uma interessante discussão das técnicas de pesquisa mais adequadas para o público infantil. Permitindo analisar as vantagens e desvantagens destas técnicas, que são apresentadas a seguir.

Quadro 11 - Métodos de pesquisa e o consumidor infantil

\begin{tabular}{|l|l|}
\hline $\begin{array}{l}\text { Método } \\
\text { Pesquisa }\end{array}$ & Considerações \\
\hline $\begin{array}{l}\text { Pesquisa } \\
\text { observacional }\end{array}$ & $\begin{array}{l}\text { Observar e gravar o comportamento das crianças é um dos métodos mais antigos utilizados } \\
\text { quando se fala de pesquisa com o consumidor infantil. Não envolve o contato ou a troca de } \\
\text { palavras com as crianças e dessa forma não produz erros de comunicação. Não requer } \\
\text { raciocínio dos sujeitos sendo pesquisados. Como problemas desta técnica têm-se a dificuldade } \\
\text { em acessar questões cognitivas, o observador pode somente inferir cognições com algum nível } \\
\text { de acurácia, o que pode gerar erros. Desde que o objetivo seja identificar um comportamento } \\
\text { concreto esta é a técnica mais adequada. }\end{array}$ \\
\hline Grupo de foco & $\begin{array}{l}\text { O autor vê este tipo de pesquisa como adequada para o segmento, mas com um caráter } \\
\text { meramente exploratório, que deve preceder esforços de pesquisa mais elaborados. Grupos de } \\
\text { foco têm sido utilizados de forma indiscriminada, toda vez que se necessita de uma aprovação } \\
\text { de projeto dentro de uma empresa. Isso não é necessário, já que estes grupos de foco também } \\
\text { podem ser muito custosos para a empresa. Os grupos de foco devem ser utilizados para: ajudar } \\
\text { no design de produto, testar linguajar, testar propagandas, embalagens e preços. Convêm não } \\
\text { utilizar as mesmas instalações que são utilizadas para os adultos, pois as mesmas inibem as } \\
\text { crianças. }\end{array}$ \\
\hline $\begin{array}{l}\text { Métodos } \\
\text { experimentais }\end{array}$ & $\begin{array}{l}\text { Este método é considerado um dos mais acurados e confiáveis métodos de pesquisa de } \\
\text { mercado. Ė utilizado primariamente para testar os efeitos do composto de marketing sobre o } \\
\text { comportamento da criança consumidora, ou seja, até que ponto o design de produto, de } \\
\text { embalagem, formatos de propaganda, displays no ponto de venda e preços (variáveis } \\
\text { independentes), impactam o gostar, querer e comprar (variáveis dependentes), }\end{array}$ \\
\hline $\begin{array}{l}\text { Téenicas } \\
\text { projetivas }\end{array}$ & $\begin{array}{l}\text { As técnicas projetivas fazem uso de estímulos que não envolvem o indivíduo, que podem lhe } \\
\text { parecer até mesmo estranhos. Ao requisitar explicações sobre este estímulo, espera-se que o } \\
\text { indivíduo projete parte de si mesmos no estímulo, fornecendo informações sobre si mesmos. }\end{array}$ \\
\hline
\end{tabular}

FONTE: Adaptado de MCNEAL; 1999, p. 240-243.

Vecchio (2002) também considera os estudos qualitativos (grupo de foco) como introdutórios, que devem ser seguidos por esforços de pesquisa quantitativos, por meio de questionários. A visão de ambos os autores repete de certa forma os preconceitos que existem sobre os métodos 
qualitativos como mera ferramenta de suporte para o método quantitativo, vertente quantitativista que domina as ciências sociais aplicadas. Marshall e Rossman (1995) indicam o uso da pesquisa qualitativa para explorar, explicar e descrever fenômenos, podendo até ser utilizado para a construção da teoria em marketing (EISENHARDT, 1989).

A Nike, sob a gerência de marketing de Scott Bedbury, utilizou durante um determinado período somente entrevistas em profundidade para monitorar o desempenho da marca no mercado (BEDBURY e FENICHEL, 2002). Nessa época, a empresa realizava entrevistas periódicas nos momentos críticos de vendas (volta às aulas, férias e início do segundo semestre), com indivíduos de 9 a 10 anos, de 11 a 12 anos, de 13 a 18 e de 25 a 34, tanto do sexo masculino como do sexo feminino (BEDBURY e FENICHELL, 2002).

As estreitas faixas etárias que a empresa utilizou, para as crianças mais novas, podem ser explicadas pelas considerações de Vecchio (2002). De acordo com o autor, existe uma grande pressão resultante da presença de crianças mais velhas no ambiente, por isso se faz necessário ter faixas de idade bastante restritas. O mesmo autor também considera não ser recomendável conduzir grupos de foco mistos, sendo mais prático separar os meninos das meninas. Outro fator que pode interferir num grupo de foco, inibindo a participação das crianças, é a presença de um líder no grupo (ACCUF e REIHER, 1997). O autor sugere que o moderador peça para que as crianças façam suas escolhas de forma secreta, de modo que os outros do grupo não saibam sua resposta.

Outra sugestão interessante feita por Accuf e Reiher (1997) diz respeito à coleta de dados intangíveis, como pistas não-verbais ou corporais. O autor dá um exemplo onde as crianças receberam um brinquedo durante um grupo de foco e não paravam quietas. Essa informação tem que ser percebida pelos que estão acompanhando o grupo de foco, pois demonstra o nível de excitação das crianças com o novo brinquedo.

A questão da duração das entrevistas também é vista por Vecchio (2002) como merecedora de análise para pesquisas com crianças. Segundo o autor, as crianças se aborrecem mais rapidamente que os adultos durante uma situação de pesquisa. Dessa forma, é melhor conduzir sessões de coleta de dados de forma mais rápida, para não perder a atenção das crianças. 
Um dos pontos levantados por McNeal (1999) que merece atenção diz respeito à utilização de medidas verbais e não verbais. Moses e Baldwin (2005) criticam duramente os métodos verbais, principalmente para crianças mais novas. De acordo com os autores, os resultados de pesquisas que se baseiam em métodos verbais podem produzir resultados enganadores, pois as crianças ainda não estão suficientemente desenvolvidas para realmente compreender as questões postas pelos pesquisadores (DONOHUE et al., 1980).

De acordo com McNeal (1999), é somente após os 9 ou 10 anos de idade que se torna possível pedir para as crianças algum tipo de raciocínio mais elaborado. Crianças abaixo dos 7 ou 8 anos são mais visuais na sua orientação para o mundo e não lidam bem com explicações verbais de conceitos (ACUFF e REIHER, 1997). Essas considerações sinalizam mais uma vez para a preponderância de estudos qualitativos, por meio da técnica de grupo de foco (LAWLOR e PROTHERO, 2003; DONOHUE et al., 1980; OATES et al., 2003) e entrevistas em profundidade (CHAN, 2000), apoiados por estímulos visuais que auxiliem na coletar dados.

Com relação à questão do nível de raciocínio exigido das crianças, Acuff e Reiher (1997) sugerem o uso de apenas um número restrito de estímulos, preferivelmente dicotômicos, de sobremaneira quando os estudos tiverem como objetos indivíduos abaixo dos 8 anos de idade. Esses estímulos devem ser equivalentes em apelo visual, cores, tamanho, número de elementos visuais e verbais, procurando sempre criar opções semelhantes na forma (ACUFF e REIHER, 1997). Os autores também sugerem o uso de estímulos tridimensionais em oposição a fotos ou desenhos bidimensionais.

Ainda dentro deste tema, Vecchio (2002) sugere que se utilize algum tipo de verificação antes de selecionar uma criança para participar em grupos de foco. O objetivo dessa etapa é perceber a capacidade da criança em se expressar. Além disso, sugere o autor, é saudável selecionar as crianças em pares de amigos, para que a mesma se sinta mais confortável na situação de pesquisa, principalmente em grupos de foco. $\mathrm{O}$ autor também sugere perguntas iniciais que tratem de temas próximos às crianças, buscando deixá-las à vontade. 
A questão do conforto da criança quando participando de uma determinada pesquisa também é analisada por McNeal (1992). Ele sugere que é possível conduzir pesquisas na própria residência da criança, local onde ela naturalmente se sente mais à vontade para participar do processo. Nestas situações é possível entrevistar a criança e posteriormente os pais. Também é sugestão do autor o uso de diários escritos pelos pais, para obter um maior número de informações sobre a criança.

Cabe ressaltar que nem sempre é necessário pesquisar diretamente a criança. Temas que tratem da descrição de comportamentos facilmente observáveis podem ser direcionados diretamente aos pais, sendo nestes casos prescindível a participação da criança (MCNEAL, 1992). Seguem alguns exemplos de situações onde os pais poderiam trazer informações mais precisas: comportamento econômico da criança, incluindo gastos, economias e renda recebida; influência da criança no comportamento de compra dos pais; hábitos de mídia da criança; e estimativas do nível de uso dos produtos pelas crianças.

\subsection{Posicionamento}

Após haver apresentado o conceito de segmentações e os temas relevantes que circundam essa área do conhecimento de marketing, parte-se para a análise teórica do conceito de posicionamento. Essa seqüência é justificada por Toledo e Hemzo (1991, p.4), que afirmam que "[o] processo de posicionamento é uma seqüência natural do processo estratégico de segmentação de mercado". Richers (2000, p.102) vai um pouco além, indicando que

[a] segmentação procura mostrar ao empresário onde encontrar grupos de pessoas que têm características de consumo semelhantes, enquanto o posicionamento, que é a operacionalização da segmentação, opera com a sensibilidade das pessoas, provocando a sua reação positiva para algum apelo que lhe pareça digno de aceitação [...].

Destarte, esta parte do trabalho buscará num primeiro momento apresentar de forma clara e extensiva a literatura que trata do conceito de posicionamento. O objetivo deste esforço teórico é demonstrar as diferentes versões que o conceito assumiu, as dificuldades encontradas para definir-lo e a evolução do conceito ao longo do tempo. 


\subsubsection{Origem do conceito de posicionamento}

A idéia do posicionamento surge como resposta para uma sociedade inundada por um excesso de comunicações, onde seria necessário criar um determinado posicionamento na mente do consumidor, levando em consideração as forças e fraquezas da empresa, assim como aquelas dos competidores (RIES e TROUT, 1972). Se naquela época o excesso de comunicações já era uma preocupação existente, o que dizer dos tempos atuais, onde com o surgimento de outras mídias (ex: internet) visualiza-se uma situação ainda mais crítica (MARSDEN, 2002).

A origem do termo posicionamento pode ser encontrada no artigo "Positioning is a game people play in today's me-too marketplace ${ }^{20,}$, o qual foi publicado na revista Industrial Marketing, em junho de 1969 (TROUT e RIES, 1972). Na seqüência, os mesmos autores, publicaram uma seqüência de artigos na revista Advertising Age. Desde então, a literatura de marketing foi profícua em trabalhos que abordam a questão do posicionamento. Apesar disso, ainda é possível encontrar diversas versões do conceito, conforme será demonstrado na seqüência. Ries e Trout (2002, p.2) definem posicionamento da seguinte forma:

O posicionamento começa com um produto. Uma mercadoria, um serviço, uma companhia, uma instituição ou mesmo uma pessoa. Talvez você mesmo. Mas o posicionamento não é aquilo que você faz com um produto. Posicionamento é aquilo que você provoca na mente do cliente em potencial. Em outras palavras, você posiciona o produto na mente do cliente em potencial.

Apesar da fama conquistada por Ries e Trout, é possível encontrar autores anteriores à dupla que já trabalhavam com termos similares, como, por exemplo, Levy (1959) e Alpert e Gatty (1969). Levy (1959) trouxe para a literatura de marketing a questão da linguagem dos símbolos, introduzindo a idéia de que as pessoas compram produtos pelo que eles significam, não pela questão funcional. Esse significado pode ser entendido como o posicionamento que o produto em questão assume nas lembranças do consumidor. "Se o fabricante compreender que está vendendo símbolos assim como vende produtos, ele poderá ver seu produto de forma mais completa.” (LEVY, 1959, p.124).

Já Alpert e Gaty (1969) abordam o conceito de posicionamento de forma um pouco distinta daquela colocada por Ries e Trout $(1972 ; 2002)$. Aqueles autores afirmam que o posicionamento

\footnotetext{
${ }^{20}$ Posicionamento é um jogo que as pessoas jogam no mercado do eu-também (tradução do autor)
} 
aborda tanto a questão das diferenças entre os segmentos, assim como as diferentes formas como eles percebem as diversas marcas. Enquanto Ries e Trout (1972; 2002), em seu turno,destacam em sua obra uma clara preocupação com o que o consumidor pensa sobre determinada marca ou produto, os outros autores indicam a necessidade de compreender os segmentos antes da empresa se dedicar a compreender qual percepção que os integrantes do segmento têm das marcas ou produtos.

Uma análise inicial dos trabalhos indica certa confusão no conceito apresentado por Alpert e Gaty (1969), que misturam os conceitos de segmentação e posicionamento. O mesmo acontece com a definição de posicionamento de Hooley e Saunders (1996), os quais também ligam a questão do posicionamento à escolha dos mercados-alvo, agregando a necessidade da diferenciação para criar a possibilidade da competitividade. Apesar dos conceitos estarem interrelacionados, não é indicado que exista este tipo de confusão na academia, devendo haver uma clara definição dos termos e dos processos que os envolvem.

Outros cientistas, na tentativa de consolidação do conceito de posicionamento, como Hemzo (1998) e Oliveira (2005), traçam um paralelo entre a origem do termo e a concepção de USP ${ }^{21}$, introduzido por Reeves (1961). Naquele momento, o conceito de USP tratava da comunicação de uma correta definição da mensagem de posicionamento (HEMZO, 1998). Analisando os autores mencionados, percebe-se que o significante posicionamento nasce de um esforço para criar um símbolo que representasse os esforços da empresa para introduzir um produto e criar uma determinada imagem deste produto, que seria, por sua vez, denominada posicionamento da marca na mente do consumidor. Aaker (1998), em sua famosa obra que versa sobre marcas, esclarece a distinção entre imagem e posicionamento ao afirmar que o posicionamento leva a concorrência em consideração. Dessa forma, é possível entender a criação de uma imagem determinada como sendo uma coisa, e construir uma imagem que leva em consideração os esforços da concorrência como outra. Posteriormente, foram desenvolvidos trabalhos acadêmicos que traziam para a discussão a questão do posicionamento estratégico da empresa, decorrente de uma análise do

\footnotetext{
${ }^{21}$ Sigla em ingles originada na palavra Unique Selling Proposition que tem como significado Proposição Única de Venda (tradução do autor)
} 
mercado. Estes outros trabalhos focam na parte estratégica do desenvolvimento do posicionamento.

Seguindo esse diapasão, Maggard (1976) coloca que, inicialmente, o termo posicionamento de produto estava relacionado aos esforços de diferenciação de produto conduzidos pelas empresas, sendo posteriormente reconstruído para trazer outros significados. Apesar dessa evolução, a academia ainda continuava muito confusa quanto à definição específica durante a década de 70 (MAGGARD, 1976; ACHENBAUN, 1974). Para resolver essa questão, Achenbaun (1974), sugere a necessidade da realização de estudos que possibilitassem a plena aplicação da teoria. Blankson e Kalafatis (1999) também acreditavam que existia uma grande dificuldade da academia de marketing em definir de forma amplamente aceita o significante posicionamento, além disso, acrescentam os autores, existe a necessidade de considerar as diferenças entre bens e serviços no momento de posicionar uma determinada oferta. Ainda na década de 80 , o conceito ainda apresentava diferentes versões na literatura, levando Aaker e Shansby (1982, p.56) a colocar que "posicionamento significa diferentes coisas para diferentes pessoas".

Diante destas considerações se faz necessário estabelecer um histórico das diferentes significações para posicionamento apresentadas ao longo da história da literatura de marketing, possibilitando assim uma melhor compreensão da visão dos acadêmicos sobre este tema. Foram levantadas inúmeras definições de posicionamento, expostas no APÊNDICE 2. A partir dessas definições é construído a análise apresentada a seguir.

Na década de 60, Alpert e Gaty (1969) definem posicionamento de produto como sendo a forma como os consumidores diferem entre si, assim como as percepções dos mesmos sobre as diferentes marcas. Esta primeira definição do conceito é falha, pois traz no seu interior a questão da segmentação, iniciando assim uma longa série de conceitos re-trabalhados que buscam esclarecer a abrangência do conceito.

Já na década de 70, Ries e Trout (1972) publicam seu famoso trabalho, no qual introduzem uma das versões mais disseminadas do conceito de posicionamento. Essa nova versão aborda apenas a imagem que o consumidor tem de determinado produto na sua mente. São deixadas de lados 
todas e quaisquer considerações que poderiam ser feitas sobre a idealização e operacionalização dessa imagem. Essa definição tem um viés claro originado do histórico profissional de ambos publicitários. Dois anos depois, Achenbaun (1974) insere a questão da estratégia, mas apenas como forma de idealizar a localização pretendida do produto no imaginário do consumidor. Apesar dessa restrição, o autor é feliz ao introduzir a idéia de que é necessário estabelecer uma área ou uma direção, em torno da qual a marca pode transitar, assim como enfatiza que a marca não pode ser tudo. Houston e Hanieski (1976) trazem a idéia de que o posicionamento deve abordar as estratégias promocionais para posicionar a marca em relação à concorrência. Este conceito agrega a idéia de que o posicionamento vai além da mera propaganda e também traz embutida a questão da análise da concorrência. Percebe-se que, aos poucos, os autores vão agregando itens relacionados à estratégia e análise de mercado.

Após as clássicas pubicações de Alpert e Gaty (1969) e, principalmente, de Ries e Trout (1978), observou-se uma explosão de estudos na área. Durante a década de 80, diversos autores trabalharam o conceito. Doyle e Saunders (1985) inovam ao estabelecer que o posicionamento é decorrente do processo de segmentação, algo que apenas Alpert e Gaty (1969) tinham pensado, mas ainda de forma confusa. Para Doyle e Saunders (1985), o posicionamento envolve a escolha da forma com que a organização vai competir em cada um dos segmentos selecionados anteriormente, assim como a necessidade da existência de alguma vantagem competitiva que permita que a empresa crie um posicionamento sustentável, ou seja, que não pode ser facilmente copiado.

Neste momento, o conceito de posicionamento realmente passa a ser considerado como parte da estratégia da empresa, envolvendo estratégias de seleção de mercados e de identificação de vantagens competitivas. Shostack (1987) traz a idéia de como avaliar o sucesso do posicionamento. Para o pesquisador, o bom posicionamento ocorre quando a marca não tem nenhuma outra marca concorrente posicionada no mesmo lugar na mente do consumidor. Apesar de tudo, essa definição não aborda a idéia de que a empresa, sendo seguidora de mercado, poderá objetivar um posicionamento idêntico ao líder de mercado. 
Um pouco mais tarde, Aaker e Shansby (1988) são um dos primeiros a identificar que o conceito de posicionamento é confuso e que a academia falhou, pelo menos até aquele momento, em defini-lo de forma coerente. Além dessa percepção, os autores reafirmam a idéia proposta por Houston e Hanieski (1976), de que o posicionamento traz como ponto de referência a concorrência e pode ser compreendido por meio do conceito de imagem. Hendom e Williams (1988), por sua vez, compactuam a idéia proposta por Doyle e Saunders (1985), ou seja, o posicionamento deriva da segmentação e pressupõe que a empresa escolheu determinado segmento para conquistar uma posição na mente dos indivíduos que o compõe. A década finaliza com os escritos de DiMingo (1989). O autor tenta trazer luz ao tema dividindo o posicionamento em duas vertentes complementares. A primeira vertente, denominada posicionamento de mercado, trata do processo de segmentação (análise de mercado e seleção de um mercado-alvo) e criação de uma estratégia competitiva. A segunda vertente, denominada posicionamento psicológico, trata da criação de uma determinada imagem na mente dos consumidores sobre a corporação ou o produto, visando levar o potencial cliente para a decisão de compra.

Primeiros autores brasileiros a discutirem o tema com o cuidado merecido, Toledo e Hemzo (1991) trazem ao principio da década de 90 uma definição que de certa forma engloba as idéias anteriores propostas pela academia. Para os autores, o conceito deriva do processo de segmentação, conforme colocado por Hendom e Williams (1988) e Doyle e Saunders (1985). A definição dos autores também aborda a necessidade do posicionamento ser construído com base em alguma vantagem competitiva existente, indo no mesmo caminho de Doyle e Saunders (1985). Toledo e Hemzo (1991) trazem como principal contribuição para esta discussão a necessidade do posicionamento ser construído tendo como base um segmento anteriormente selecionado, e ser fruto de uma análise ambiental das forças e fraquezas da empresa e de seus concorrentes.

A partir dessa época, a relação entre posicionamento e estratégia começa a tomar forma. Lautman (1993) traz uma nova visão para o conceito de posicionamento, colocando a necessidade de ser feita uma completa análise do produto, visando identificar seus atributos, os benefícios oferecidos ao cliente e usar a comunicação para transmitir esses atributos e benefícios. Essa definição traz embutido o conceito de diferenciação. O que é natural, pois para posicionar o produto em um 
local distinto na mente do consumidor, o produto deve carregar algum atributo ou trazer um beneficio que seja claramente distinto do que é oferecido pela concorrência.

Ansari et al. (1994) complementa a idéia de Lautman (1993) dizendo que os atributos devem ser relevantes para o consumidor, reafirmando a necessidade de o posicionamento ser uma decorrência do processo de segmentação, pois só assim a empresa terá um grupo coeso de clientes como mercado-alvo e poderá identificar de forma mais precisa quais são os atributos relevantes para esse grupo em particular. Os autores também agregam a idéia de que o preço pode ter uma influência no posicionamento pretendido. Começa a aparecer, neste momento, a idéia de que o posicionamento tem uma relação com o composto de marketing.

Wyner e Owen (1994) propõem a necessidade de o posicionamento trabalhar as dimensões relevantes para o cliente, suportando a definição de Lautman (1993), e introduzindo a idéia de que os clientes têm um mapa mental das ofertas existentes no mercado, sendo que esse mapa é estruturado pelo cliente com base naquelas dimensões que considera relevantes. Hooley e Saunders (1996) voltam a trabalhar o conceito, mais de dez anos após a primeira intervenção, e identificam a necessidade da empresa determinar onde irá competir e qual o diferencial que irá oferecer aos clientes.

Aaker (1998), em novo trabalho, reafirma as colocações feitas por ele e Shansby em 1988, esclarecendo que o conceito de posicionamento deriva da idéia de imagem e deve levar em conta a concorrência. A contribuição de Aaker (1998) tem como principal contribuição trazer o aporte da literatura que trabalha a construção de imagem para a área de posicionamento. Ao estabelecer que a imagem deve ser gerenciada em conjunto com a análise da concorrência, o autor sinaliza para a necessidade de estudos que abordem uma análise de mercado. McDonald e Dunbar (1998) apenas reafirmam a necessidade do processo de posicionamento ser decorrente do processo de segmentação. Blankson e Kalafatis (1999) são um dos primeiros autores a inserirem a questão do posicionamento como sendo adequado para produtos e serviços, além disso, os autores reafirmam o que foi colocado por Lautman (1993) com relação à diferenciação. Já no fim da década, Richers (2000) traz a idéia que o posicionamento é o lugar que a marca ocupa no mercado com um mínimo de interferência das outras marcas. Para o autor, esse lugar é resultante da forma como o 
consumidor percebe e compreende o produto, idéia que também é apresentada por Lambim (2000).

Já na década do 00, Ferrell e Hartline (2005) fazem coro à discussão, ao colocar que a diferenciação refere-se ao produto em si, enquanto as percepções do consumidor sobre o produto podem ser referentes a benefícios reais ou imaginários. Hassan e Craft (2005) trazem mais um aporte valioso para o esforço epistemológico da academia de marketing e definem que o posicionamento envolve o direcionamento de recursos de marketing para os segmentos-alvo. Essa idéia remete ao conceito de Ansari et al. (1994) no momento em que trata dos recursos de marketing, ou seja, o composto de marketing. Oliveira e Campomar (2006) trazem na sua definição a idéia de que o posicionamento é, na verdade, uma proposta de valor, devendo ser mais atrativa e distintiva do que o oferecido pela concorrência.

Seguindo o mesmo diapasão, Hartmann et al. (2006) afirmam de forma categórica que o posicionamento é baseado nas interações de todas as ferramentas de marketing, sinalizando para uma importância maior da comunicação, por ser essa ferramenta a maior responsável pela criação da imagem da marca (AAKER, 1998). Ainda, tanto Srivastava (2006), quanto Keller e Machado (2006) e Kerin et al. (2008) tratam o posicionamento como o lugar que o produto ocupa na mente do consumidor, tendo em consideração a concorrência (KERIN et al., 2008).

A análise dos diferentes conceitos de posicionamento ao longo do período pesquisado permitiu uma melhor compreensão do mesmo. Cabe neste momento trazer algumas considerações finais sobre essa questão, tentando agregar à discussão com uma visão completa, mas parcimoniosa do assunto, suportada pela extensão revisão realizada.

O posicionamento decorre do processo de segmentação, sendo necessário identificar um segmento especifico para poder desenvolver um posicionamento pretendido e colocá-lo em prática. Esse processo de escolha do segmento pode ser melhor compreendido por meio da idéia de Macro e Micro Segmentação (LAMBIM, 2000). Primeiro a empresa escolhe um determinado mercado para atuar, para depois identificar as nuances que este mercado apresenta. 
A partir da escolha do segmento-alvo, a empresa deve conduzir o seu esforço de posicionamento. De acordo com Toledo e Hemzo (1991) o processo como um todo se denomina posicionamento estratégico, que pode ser dividido em posicionamento de mercado e posicionamento psicológico. No posicionamento de mercado "a empresa estabelece a posição desejável sob condições reais de seu ambiente competitivo", já o posicionamento psicológico "define a forma de comunicação dessa posição para o mercado" (TOLEDO e HEMZO, 1991, p. 5).

Uma questão se faz presente neste momento. Onde entra a questão do composto de marketing e a sua participação no posicionamento estratégico, ou seja, no posicionamento de mercado e no posicionamento psicológico? Uma série de autores acredita que o composto de marketing deve fazer parte do processo de posicionamento (HASSAN e CRAFT, 2005; HARTMANN et al., 2006; ANSARI et al., 1994). Essa idéia faz sentido se for analisada a forma como o consumidor capta a imagem de uma empresa ou de um produto. Todos os esforços de marketing da empresa geram estímulos que auxiliam o consumidor a compor a imagem de uma empresa em sua estrutura mental (HASSAN e CRAFT, 2005; HARTMANN et al., 2006; ANSARI et al., 1994).. Hartmann et al. (2006) dizem que a comunicação seria a principal ferramenta para criar essa imagem, mas essa afirmação pode ser contestada dependendo da categoria de produto em que se encaixa a oferta da organização.

A Ilustração 12 apresenta o esquema de Silk (2008) para as ações de marketing de uma empresa, que resume o processo de posicionamento estratégico e demonstra a importância do composto de marketing para a efetivação do fenômeno. 


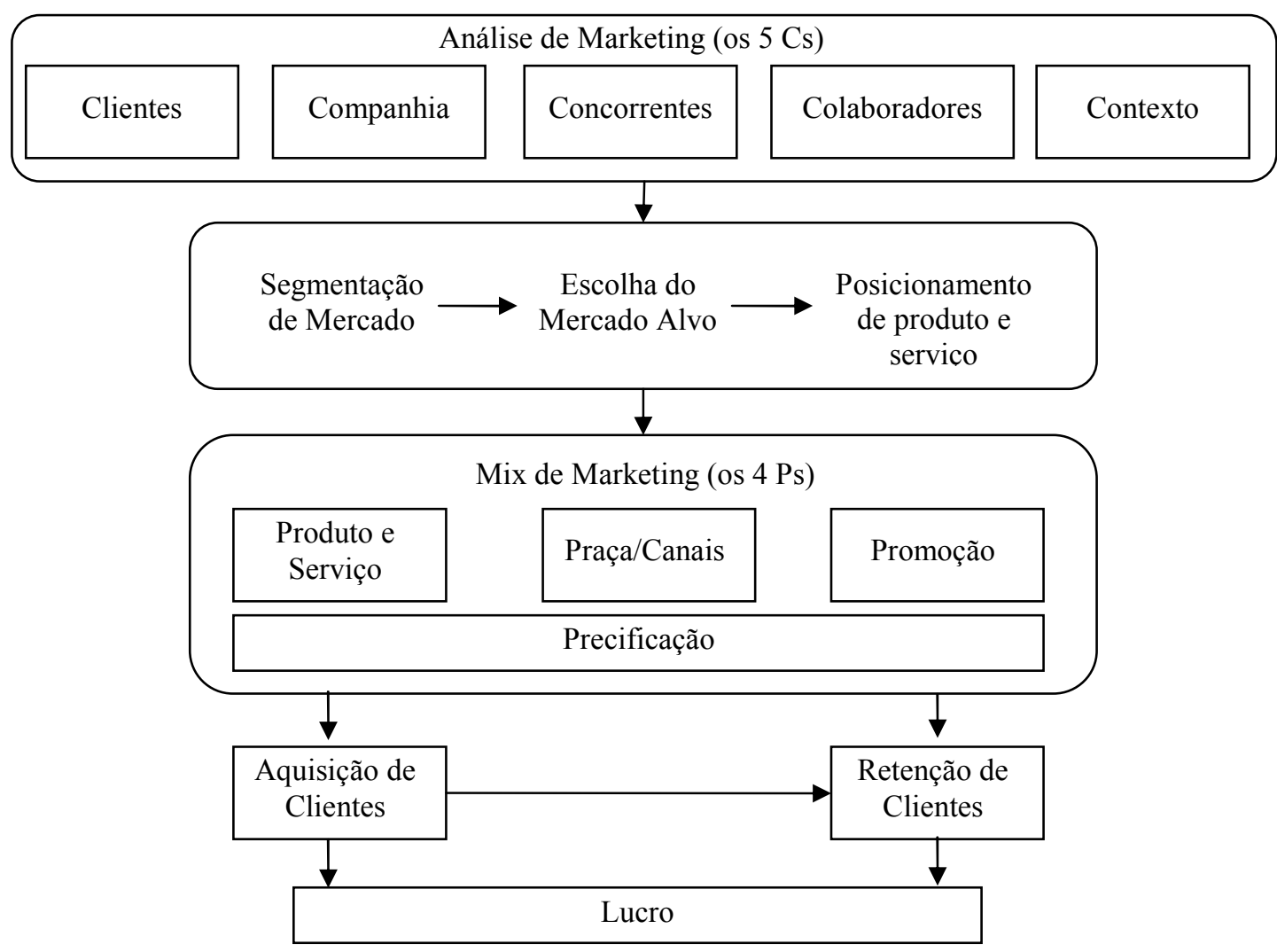

Ilustração 12 - Esquema do Processo de Marketing Fonte: Adaptado de SILK; 2008, p.16.

A parte denominada de análise de marketing seria a etapa onde a empresa faz uma complexa análise do seu ambiente para determinar onde está situada. Toledo e Hemzo (1991) inserem essa análise no processo de posicionamento de mercado. Os mesmos autores sugerem que o passo seguinte seria a segmentação de mercado com a posterior seleção dos mercados a serem atendidos e o estabelecimento das estratégias competitivas. As estratégias competitivas são determinadas pela análise de pontos fortes e fracos da empresa e de seus concorrentes, ou seja, uma análise SWOT.

A partir dessa análise a empresa deve conduzir esforços de diferenciação, ou seja, “[...] o estabelecimento de um pacote de benefícios ou valores, expressos por produto, preço, distribuição e por todo o mix de capacidades e serviços de suporte da empresa" (TOLEDO e HEMZO, 1991, p.9). O passo seguinte, de acordo com Toledo e Hemzo (1991) seria o processo de criação do posicionamento psicológico. 


\subsubsection{Posicionamento de mercado}

Ao tomar as decisões sobre o seu posicionamento de mercado, a empresa deve decidir por algum curso de ação, possivelmente por meio de um planejamento estratégico da implementação do posicionamento escolhido (ACHENBAUN, 1974). Além disso, complementa o autor, é necessário analisar as limitações que a própria estrutura da empresa e do mercado (concorrência) impõe às estratégias possíveis de serem implementadas. Também faz parte desse processo, a definição da missão da empresa, o estabelecimento de metas e objetivos, fundamentados na análise compreensiva do mercado e das próprias capacidades da empresa (TOLEDO e HEMZO, 1991). Ao estudar esse mercado, a empresa pode focar seus esforços em segmentos onde as empresas que o integram apresentam deficiências (DIMINGO, 1989). Ao identificar essa oportunidade, a companhia poderá competir mais efetivamente por meio do correto direcionamento dos seus esforços de marketing (TOLEDO e HEMZO, 1991).

O posicionamento pretendido pela empresa deve estar fundamentado nas vantagens competitivas sustentáveis, ou seja, que não podem ser facilmente copiadas pelos competidores (DOYLE e SAUNDERS, 1985). Essa vantagem competitiva dever resultar na criação de atributos que sejam diferenciadores na percepção do consumidor sobre o valor oferecido pela empresa (OLIVEIRA, 2005), devendo então atender de alguma forma as necessidades dos consumidores (HOOLEY e SAUNDERS, 1996; BLANKSON e KALAFATIS, 1999). Além disso, esse esforço deve permitir a criação de um posicionamento psicológico adequado para os objetivos da empresa. Essa visão pressupõe a identificação da forma como a empresa irá competir (HOOLEY e SAUNDERS, 1996), distribuindo de forma correta os recursos de marketing disponíveis para atender os segmentos selecionados anteriormente (HASSAN e CRAFT, 2005).

O posicionamento estratégico deriva das análises realizadas pelos profissionais de marketing com relação tanto às forças e fraquezas da empresa, como às oportunidades e ameaças apresentadas pelo mercado (CHERNATONY, DANIELS e JOHNSON, 1993; TOLEDO e HEMZO, 1991). Diante das informações coletadas, é responsabilidade do gestor encontrar alternativas de posicionamento que alinhem as forças da empresa com as oportunidades de mercado (CHERNATONY, DANIELS e JOHNSON, 1993), para posteriormente direcionar os recursos de 
marketing para o mercado selecionado (HASSAN e CRAFT, 2005). Percebe-se no discurso dos autores claramente a existência de uma corrente que aborda a questão do posicionamento como fator estratégico da empresa, e sendo assim, exigindo uma série de atividades inerentes ao processo de planejamento estratégico da companhia, como uma análise $\mathrm{SWOT}^{22}$. Adotando tais práticas, a organização estará apta a atender melhor as exigências do mercado em comparação com seus concorrentes (TOLEDO e HEMZO, 1991).

Com base nas considerações acima percebe-se que é a partir do posicionamento de mercado que a empresa deve considerar o posicionamento psicológico mais adequado para atender as necessidades dos seus consumidores, tomando-se em conta as questões relativas às capacidades da empresa e seu entorno concorrencial.

\subsubsection{Posicionamento psicológico}

O posicionamento psicológico trata basicamente da comunicação da imagem que a empresa quer que os potenciais consumidores tenham da sua oferta. A escolha do posicionamento pretendido deve levar em conta os concorrentes para construir o real significado do conceito. Sem essa consideração sobre a concorrência Aaker e Shansby (1988) considera que a empresa estaria tão somente trabalhando a imagem da sua oferta. Partindo desta idéia, esta etapa do trabalho enfoca as indicações da literatura para a construção da imagem e do modo como isso pode ser feito para gerar o posicionamento psicológico.

Levy (1959), ainda na década de 50, destaca em seu artigo o surgimento de um novo tipo de consumo: o consumo de símbolos. De acordo com o autor, as pessoas não compram mais produtos, mas sim o significado que eles carregam. Esse tipo de consumo surge como uma forma dos consumidores construírem sua identidade individual. Diante deste cenário torna-se importante para a empresa construir marcas que tenham algum nível de significado para os seus consumidores, dando-lhes a oportunidade de utilizar a marca da empresa como uma forma de construção de sua identidade pessoal. Dessa forma, surge a questão da construção de uma imagem de marca, a qual Aaker e Shansby (1988) colocam como o conceito a partir do qual o

\footnotetext{
${ }^{22}$ Do termo SWOT - Strengths, Weakness, Opportunities and Treats - o qual pode ser traduzido para : Forças, fraquezas, Oportunidades e Ameaças
} 
próprio o significante posicionamento é construído. Segundo os autores, o posicionamento seria a construção da imagem da marca com uma preocupação nos concorrentes da empresa, idéia compartilhada por Ries e Trout (1972).

A questão da criação de uma imagem diferenciada daquela dos concorrentes é uma ação decorrente da análise dos consumidores, tanto para identificar qual seriam suas preferências, como para identificar a imagem que eles abstraem das marcas dos concorrentes (ALPERT e GATTY, 1969). A questão da necessidade de investigações para compreender as questões colocadas anteriormente é salientada por Achenbaun (1974). Para o autor, é imprescindível a realização de pesquisas de mercado para melhor definir o posicionamento que será transmitido pela empresa com relação à determinada marca. A definição do posicionamento com base na percepção dos consumidores sobre as marcas existentes parte da premissa de que a empresa claramente identificou aqueles atributos que são relevantes para os consumidores e, com base nestes atributos, idealizou um determinado posicionamento para ser comunicado para os consumidores.

De acordo com Houston e Hanieski (1976), estes atributos podem ser tangíveis, como uma característica física do produto, ou intangíveis, como os símbolos associados à marca ou produto, seguindo a idéia do consumo simbólico de Levy (1959). Já Lambin (2000) é mais assertivo sobre essa questão e afirma que, para identificar o posicionamento de uma marca, faz-se necessário o estudo da imagem da marca. Imagem esta composta por associações, conforme apresenta Aaker (1998) na Ilustração 13. 


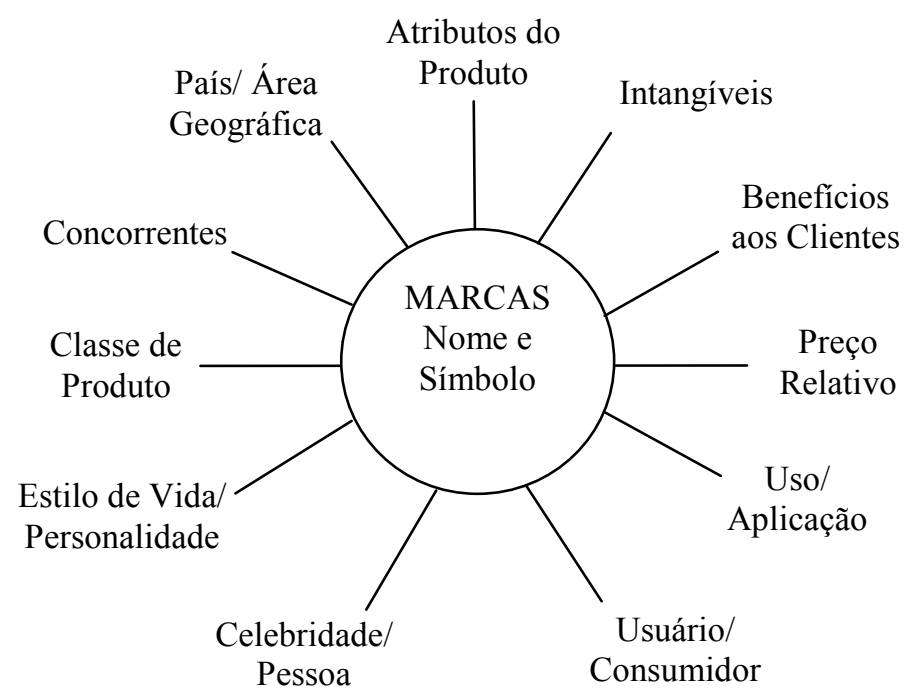

\section{Ilustração 13 - As Associações de Marca} FONTE: AAKER; 1998, p.120.

A Ilustração 13 traz uma série de exemplos que podem compor a gama de associações relacionadas à determinada marca. Esse agrupamento é que comporá o posicionamento psicológico que o consumidor tem daquela marca. Ainda, esse novo significante traz alguns desdobramentos estratégicos para a empresa (AAKER, 1998, p. 116):

- Ajudam a processar/achar informação

- Diferenciação/posicionamento

- Razão de compra

- Criar atitudes positivas/feelings

- Base para extensões

Aaker (1998) salienta que além de compreender quais são os encadeamentos presentes na mente do consumidor, também se faz necessário averiguar qual a força de cada uma das associações. Dessa forma, a empresa teria uma visão melhor do seu próprio posicionamento, sob a perspectiva do consumidor. Ao colocar a questão da diferenciação como uma das vantagens da construção das associações à marca da empresa, Aaker (1998) sinaliza ainda que é possível construir uma diferenciação da oferta da empresa com base no posicionamento psicológico desenvolvido.

DiMingo (1988) considera que o posicionamento psicológico deve ir além de um simples slogan que transmita uma determinada idéia para o consumidor. Ele considera que o consumidor pode em alguns casos ser enganado por um slogan que vende algo que a empresa não está preparada 
para oferecer, mas isso só acontece uma vez. Sendo assim, a empresa que quer criar um determinado posicionamento na mente do consumidor deve trabalhar não somente a imagem que está transmitindo, mas também deve produzir essa imagem de forma real e inequívoca, ou seja, transpondo a imagem que está sendo comunicada para o mundo real. "O mix de marketing, constituídos pelos produtos, preço, promoção e distribuição, são os meios pelos quais a empresa traduz sua estratégia de uma declaração de intenção em um esforço no mercado (HOOLEY e SAUNDERS, 1996, P.57). É em função destas considerações que o posicionamento estratégico e o psicológico devem estar firmemente amarradas com a operacionalização do composto de marketing.

De acordo com Toledo e Hemzo (1991) o posicionamento psicológico deriva obrigatoriamente do posicionamento de mercado, visando a criação de uma imagem organizacional ou de produto distinta. Ao trabalhar o seu posicionamento psicológico a empresa procura fazer com que o consumidor modifique suas atitudes e o seu comportamento, encorajando-o a comprar, experimentar ou comprovar as vantagens anunciadas (TOLEDO e HEMZO, 1991). Ao colocar a questão da comprovação das vantagens anunciadas os autores remetem mais uma vez a necessidade da empresa transpor o seu posicionamento para o mercado, na sua forma mais prática, operacionalizando todos os itens do composto de marketing de forma integrada para que transmita a mesma mensagem, aquela idealizada por meio do posicionamento psicológico.

De acordo com Shostock (1987), o posicionamento é algo além de esforços de comunicação, que deve ter grande impacto nas outras estratégias da empresa, principalmente em relação à precificação, ao produto em si e à distribuição. Essa colocação permite compreender melhor a idéia de Toledo e Hemzo (1991) com relação à necessidade de estabelecer um posicionamento que tenha uma forte conexão com as outras ferramentas de marketing, como, por exemplo, preço, praça/distribuição e produto. Gouvêa (1991) também faz voz a essa visão, sinalizando a necessidade de dar atenção aos outros elementos do composto de marketing (preço, produto e ponto de distribuição) no momento da construção do posicionamento desejado. Lambin (2000) também expressa sua preocupação com a coerência entre o posicionamento e as variáveis de marketing (preço, distribuição, comunicação, embalagem, serviços etc), da mesma forma que 
Hartmann et al. (2006) relacionam o posicionamento à interação de todas as ferramentas de marketing, com especial atenção para a comunicação.

\subsubsection{Processo de posicionamento}

O desenvolvimento de uma determinada imagem deve ser pautado pela tentativa de criar um posicionamento que seja sustentável e que não seja facilmente copiado pela concorrência (DOYLE e SAUNDERS, 1985). Essa idéia traz duas importantes considerações. A primeira trata do desenvolvimento de um posicionamento que seja divulgado junto aos consumidores, tratando da construção de uma determinada imagem (posicionamento psicológico). A segunda trata da construção desta imagem com base numa estrutura de entrega do produto ou serviço que realmente entregue o que foi prometido na imagem divulgada (posicionamento competitivo). Ao construir uma imagem distinta daquela que os competidores desenvolveram, e tendo desenvolvido uma estrutura operacional que realmente entregue a imagem divulgada, a empresa estará apta a construir uma vantagem competitiva sustentável.

É fundamental para o desenvolvimento desse posicionamento a realização de uma prévia pesquisa de posicionamento (HOOLEY e SAUNDERS, 1998). Essa pesquisa teria como principal preocupação identificar como os clientes percebem os produtos os produtos e serviços concorrentes. A partir dessas considerações compreende-se que

[t]anto a segmentação como o posicionamento são, portanto, meios de aumentar a nitidez de um quadro que mostra como os clientes podem ser agrupados em um mercado e como estes clientes agrupam os produtos e serviços oferecidos (HOOLEY e SAUNDERS, 1998. p.237).

Partindo destas idéias, a organização poderá trabalhar para desenvolver sua estratégia com base numa ampla análise do mercado, a qual possibilita uma melhor compreensão das características do mercado e das percepções que os consumidores carregam sobre as distintas ofertas de marketing disponibilizadas pelas diferentes empresas que concorrem no mercado. Complementando a idéia de Hooley e Saunders (1998), Toledo e Hemzo (1991, p.6) indicam que

Uma oportunidade de mercado deve ser entendida como uma situação favoravelmente atrativa a uma ação estratégica de marketing, a qual pode causar um impacto sobre o negócio desde que a empresa apresente condições de manter uma vantagem competitiva sustentável. 
Sendo assim, percebe-se que o posicionamento da empresa deve ser construído a partir de características singulares da empresa, que possam ser traduzidas para um diferencial de mercado que não pode ser facilmente copiado, sendo então a fonte de uma vantagem competitiva duradoura. A identificação dessas oportunidades é decorrente da capacidade da corporação em construir um quadro que permita a visualização de como o mercado está composto, tanto pela ótica dos consumidores que o compõem, como pela ótica das opiniões que estes consumidores portam sobre as marcas, produtos ou organizações.

Toledo e Hemzo (1991) desenvolveram um modelo de posicionamento que busca apresentar as etapas necessárias para o correto desenvolvimento prático do processo de posicionamento. $\mathrm{Na}$ Ilustração 14 apresenta-se uma ilustração esquemática do processo de posicionamento desenvolvido pelos autores. 
ETAPA ZERO - Bases para o posicionamento de mercado

\begin{tabular}{|l|l|}
\hline $\begin{array}{l}\text { - Identificar o que o mercado quer e necessita. } \\
\text { - Identificar as forças e fraquezas da empresa e de } \\
\text { seus concorrentes. } \\
\text { - Identificar as exigências necessárias para } \\
\text { atender o mercado melhor que a concorrência. }\end{array}$ & $\begin{array}{l}\text { - Definição da missão da } \\
\text { empresa } \\
\text { Estabelecimento de } \\
\text { objetivos e metas e } \\
\text { estratégias de crescimento. }\end{array}$ \\
\hline
\end{tabular}

ETAPA UM - Identificação dos segmentos de mercado

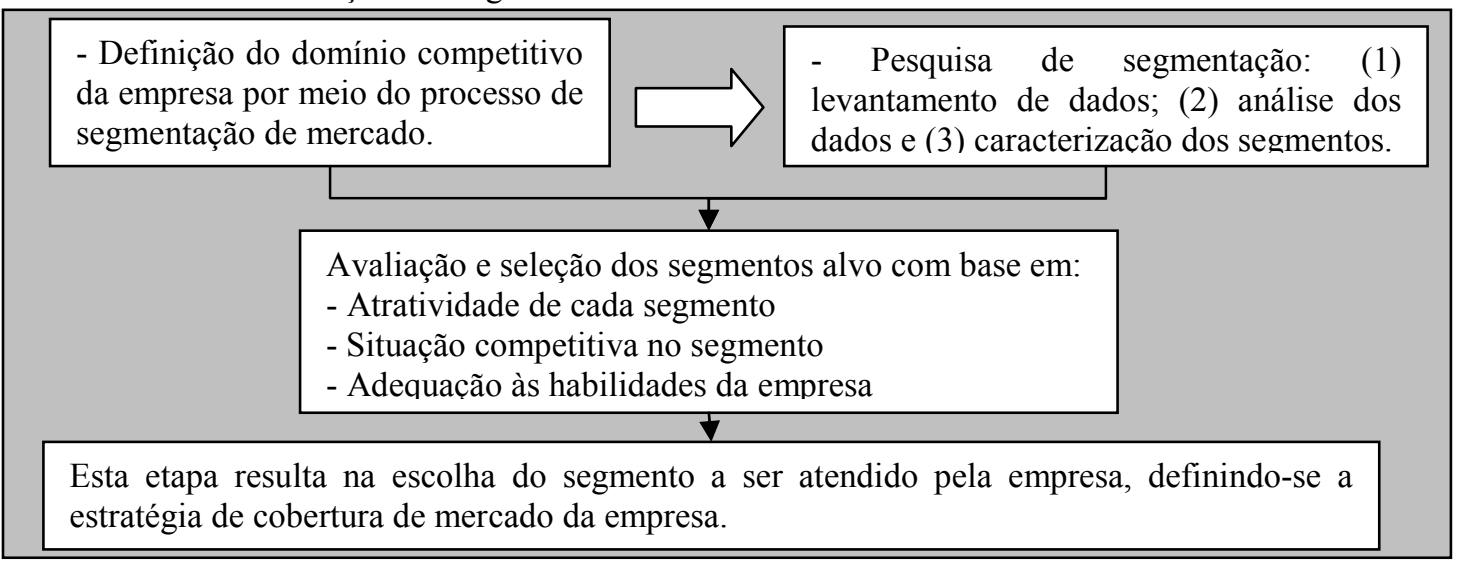

ETAPA DOIS - Estabelecimento das estratégias competitivas

\begin{tabular}{|l|l|}
\hline $\begin{array}{l}\text { Desenvolvimento da estratégia } \\
\text { competitiva que será adotada pela empresa }\end{array}$ \\
$\begin{array}{l}\text { Esta etapa resulta no entendimento das capacidades da empresa perante as restrições } \\
\text { existentes e a definição de uma oferta diferenciada que tenha alguma atratividade para o(s) } \\
\text { segmento(s)-alvo escolhido(s). }\end{array}$ \\
\hline
\end{tabular}

ETAPA TRÊS - Definição do posicionamento psicológico

\begin{tabular}{l}
$\begin{array}{l}\text { - Desenvolvimento de uma } \\
\text { identidade corporativa ou de } \\
\text { produto distinta. }\end{array}$ \\
$\begin{array}{l}\text { Desenvolvimento da estratégia de posicionamento levando em consideração dois fatores: } \\
\text { - As diferenças existentes entre os diversos segmentos de mercado } \\
\text { - A interação entre linhas e itens do composto de produtos da empresa }\end{array}$ \\
$\begin{array}{l}\text { Esta etapa resulta na definição do posicionamento psicológico, o qual pode ser baseado nas } \\
\text { seguintes opções: baseado em atributos específicos do produto; em benefícios, necessidades ou } \\
\text { solução de problemas; em ocasiões especificas de uso; em categorias de usuários; em oposição a } \\
\text { outro produto e dissociação de uma categoria de produto. }\end{array}$ \\
\hline
\end{tabular}

Ilustração 14 - Modelo do processo de posicionamento de Toledo e Hemzo FONTE: Adaptado de TOLEDO e HEMZO; 1991, p.5-14. 
Aaker e Shansby (1988, p.58-62) também trazem um modelo com as etapas necessárias para o desenvolvimento de uma estratégia de posicionamento:

1. Identifique os competidores: não é uma tarefa fácil, tendo em vista que podem existir competidores primários e competidores secundários. Além disso, existem diferentes formas de definir o mercado onde a empresa está atuando.

2. Determine como os competidores são percebidos e avaliados: identificar quais são as associações que os consumidores carregam com relação aos competidores. Essas associações podem incluir atributos do produto, grupos de usuários do produto, contexto de uso etc.

3. Determine a posição dos competidores: identificar o posicionamento que os competidores têm na mente do público-alvo. Esse posicionamento deve abordar a visão do consumidor sobre os concorrentes e as suas percepções das semelhanças e diferenças entre os concorrentes. Uma forma de fazer este tipo de análise é por meio de mapas perceptuais.

4. Analise os consumidores: neste momento procura-se entender como o mercado está dividido. É possível trabalhar idéias como "Qual o papel do nosso produto no estilo de vida do nosso consumidor?”, “O que realmente motiva este consumidor?" "Quais hábitos ou padrões de consumo são relevantes?”

5. Selecione uma posição: somente a partir das quatro etapas anteriores é possível compreender melhor o consumidor e a forma como o mercado está composto, possibilitando assim a identificação do posicionamento mais adequado para a empresa diante da configuração atual do mercado. Ao posicionar seu produto a empresa estará se comprometendo com determinado segmento de mercado. É recomendável também conduzir uma análise econômica para identificar se tal posicionamento será rentável (tamanho do mercado $\mathrm{x}$ probabilidades de penetração de mercado). Por último, os autores recomendam: não tente ser algo que não é, ou seja, se for apresentar determinado posicionamento ao consumidor por meio da comunicação a empresa deve ter certeza de que poderá realmente entregar aquela promessa na vida real. 
6. Monitore a posição: a empresa deve monitorar constantemente, por meio de pesquisas, o seu posicionamento atual.

Os dois modelos apresentados, de Toledo e Hemzo (1991) e Aaker e Shansby (1988), apresentam algumas similaridades. A principal delas é quando se coloca a análise do mercado como ponto de partida para o desenvolvimento do processo. Toledo e Hemzo (1991) vão um pouco além e incluem também a necessidade de uma análise interna. Esse tipo de análise é recomendável, pois pode daí surgir a compreensão das vantagens competitivas que a empresa possui, para que desta vantagem se construa um modelo de negócios diferenciado. Já o modelo de Aaker e Shansby (1988) traz como importante contribuição a necessidade de realização de um constante monitoramento do que está sendo feito pela empresa em relação ao posicionamento. Oliveira e Campomar (2006, p. 13) complementam propondo que "[...] o posicionamento deve ser avaliado regularmente a fim de se identificar mudanças nas preferências do público-alvo e nas estratégias dos concorrentes, para que possam ser tomadas medidas corretivas".

Seja qual for a estratégia de posicionamento adotada pela empresa, torna-se necessária sua implementação na prática. Hooley e Saunders (1996) tratam essa questão como a implementação do mix de marketing. Seguindo a proposta dos autores, a empresa encontra-se imbuída do objetivo de transformar a declaração de intenção (posicionamento psicológico) num esforço de mercado (HOOLEY e SAUNDERS, 1996). A empresa deve perceber que todas as variáveis de marketing devem ser estrategicamente coordenadas para transmitir aquela imagem que foi apresentada ao consumidor. Não basta apenas trabalhar a questão da comunicação, é necessário que todos os outros elementos do composto de marketing (preço, praça e produto) estejam de acordo com o que se está comunicando ao consumidor como sendo o posicionamento da marca.

\subsubsection{Modelo do processo de posicionamento estratégico}

A partir das considerações elaboradas nos tópicos anteriores, é oferecida a Ilustração 15 como forma esquemática de resumir o conceito de posicionamento estratégico, com sua composição dividida entre o posicionamento de mercado e o posicionamento psicológico. Essa ilustração não tem a pretensão do esforço conduzido por Toledo e Hemzo (1991), mas sim objetiva apresentar de forma clara a relação entre os conceitos abordados neste trabalho. 


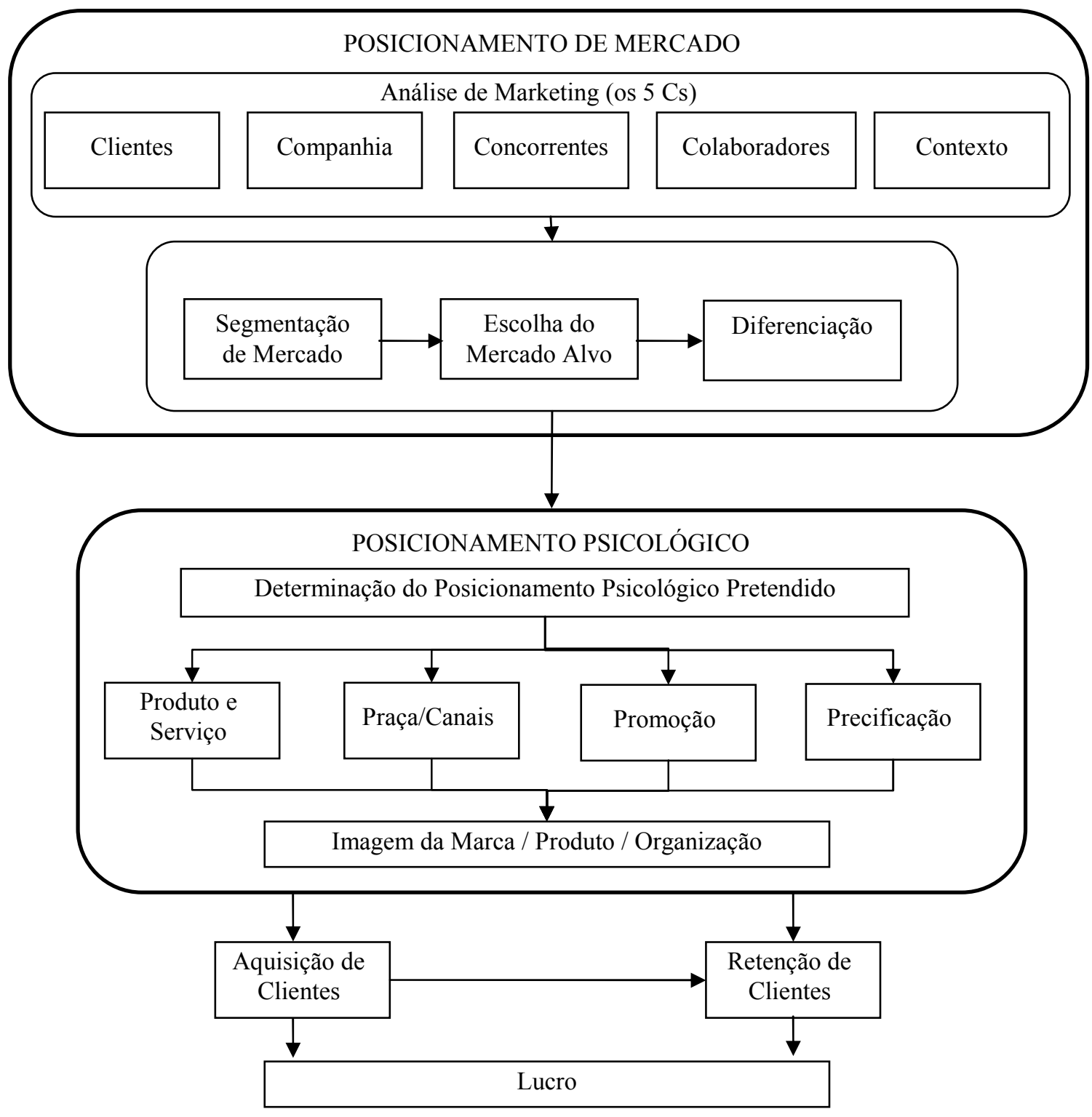

Ilustração 15 - Processo de Posicionamento Estratégico

Fonte: Elaborado pelo autor com base em SILK; 2008, p.16 e revisão teórica.

Observando a ilustração acima é possível compreender melhor os conceitos abordados neste trabalho como um todo. A idéia de segmentação não existe por si só, ela tem sua utilidade e existência relacionada ao processo de uso dessas informações para a realização do posicionamento. Já o posicionamento não necessariamente necessita da existência de uma etapa anterior (segmentação). É possível que a empresa defina por si só o mercado de sua atuação e 
realize as atividades relacionadas ao posicionamento de maneira não estruturada e planejada, mas isso não significa necessariamente que a empresa terá um insucesso.

O processo de segmentação tem como objetivo fornecer para os profissionais de marketing os insumos necessários para adequar e comunicar sua oferta para o segmento escolhido. Por isso o processo de segmentação está inserido no processo de posicionamento de mercado, pois a definição de como o processo de segmentação será conduzido (definição do mercado e das variáveis de segmentação) é realizada de forma adequada quando está ligada ao processo de análise ambiental, o que na ilustração acima denominou-se de análise de marketing.

\subsubsection{Efetividade do posicionamento}

Aaker (1998) afirma que o posicionamento é a criação de uma imagem relacionada a um certo número de associações, dentro de um quadro de refêrencia que inclui a concorrência, porém "uma associação e uma imagem representam ambas as percepções que podem ou não refletir uma realidade objetiva." (AAKER, 1998, p.115). Foram apresentados, na Ilustração 13, uma série de exemplos que podem fazer parte das associações que o consumidor faz da marca da empresa, ou seja, do posicionamento entendido pelo consumidor. A partir destas considerações percebe-se que nem sempre o consumidor terá nas suas lembranças exatamente aquilo que foi planejado pela empresa. Também é possível compreender que a empresa pode trabalhar um posicionamento que foge da realidade objetiva dos fatos, criando percepções diferenciadas em relação ao que realmente pode oferecer.

É importante lembrar que "[u]m consumidor que venha a adquirir um produto com base em algum benefício associado ao produto, mas não oferecido realmente, só cometerá esse erro uma vez" (TOLEDO e HEMZO, 1991, p.3). Caso esse beneficio associado ao produto tenha sido uma estratégia deliberada da empresa, entende-se que foi um risco assumido pelos gestores de marketing da corporação. "O problema para os profissionais de marketing é que os consumidores podem interpretar o mesmo estímulo de modo diferente" (MOWER e MINOR, 2003, p.56). Partindo da idéia de Mowen e Minor (2003) identifica-se um potencial problema para a empresa. Caso esse benefício associado tenha sido resultante de um problema de interpretação, a empresa enfrentará o aparecimento de um determinado posicionamento que não era planejado. Deve-se 
destacar, no entanto, que, na melhor das hipóteses, esse "novo" posicionamento pode ter uma conotação positiva, caso isso não aconteça a empresa terá que dedicar esforços para corrigir essa percepção equivocada do consumidor.

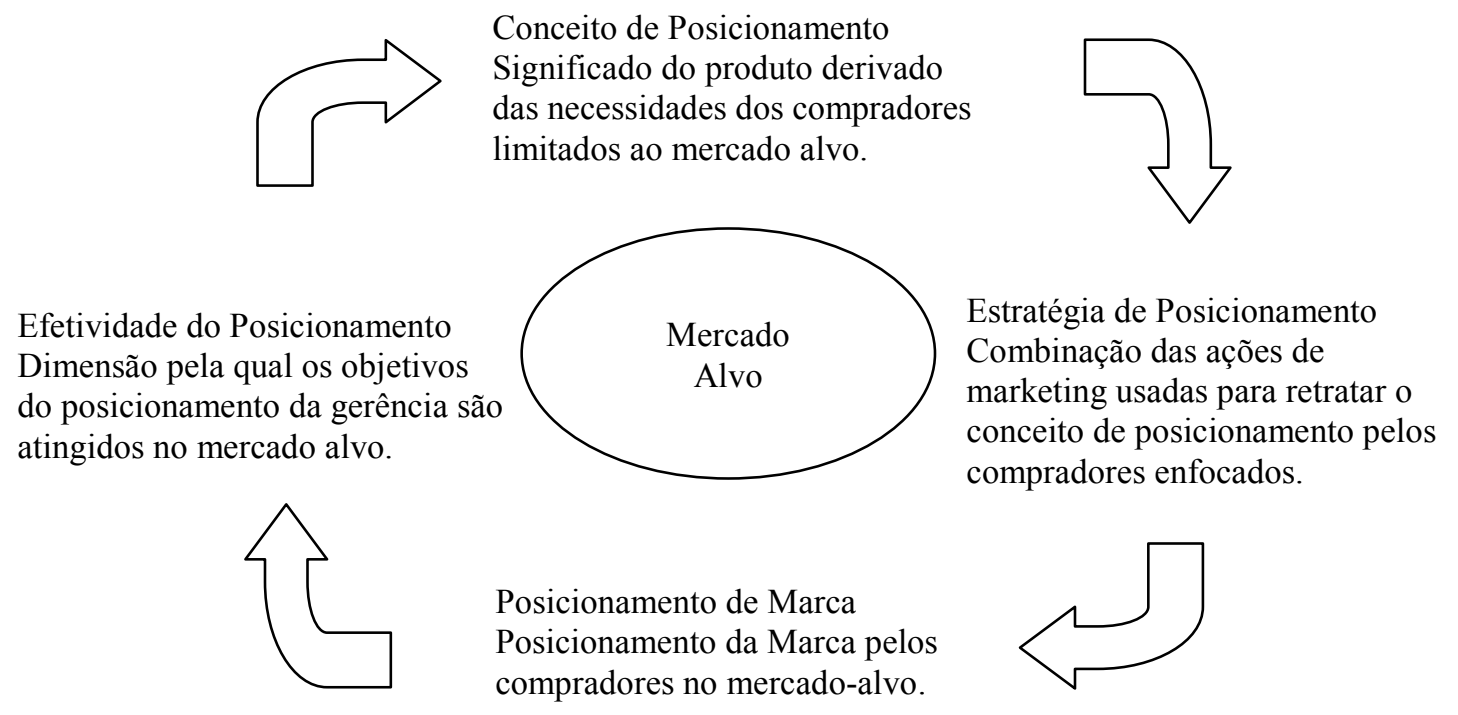

\section{Ilustração 16 - O processo de Posicionamento}

FONTE: Adaptado de CRAVENS; 1991 apud MONTE; 1998, p.57.

Deve-se destacar, no entanto, que, na melhor das hipóteses, esse "novo" posicionamento pode ter uma conotação positiva, caso isso não aconteça a empresa terá que dedicar esforços para corrigir essa percepção equivocada do consumidor é apresentado o processo de posicionamento de Cravens (1991) apud Monte (1998) na Ilustração 16. Nesta visão do processo, é inserida a questão da efetividade do posicionamento, o que remete à questão do monitoramento do posicionamento, conforme apresentado por Aaker e Shansby (1988). Ambos os autores pretendem, ao incluir essa fase no processo de posicionamento, indicar que não é possível realizar este tipo de atividade de marketing sem realizar ações de acompanhamento, em função das dificuldades de compreensão ou entendimento daquelas mensagens que são transmitidas pela empresa como sendo seu posicionamento (MOWER e MINOR, 2003; AAKER, 1998) 


\subsubsection{Reposicionamento}

De acordo com Kerin et al. (2008, p.241) "[o] reposicionamento de produto envolve a mudança do lugar que uma oferta ocupa na mente dos consumidores com relação aos produtos da concorrência". Richers (2000) analisa o mercado e identifica uma tendência cada vez mais crescente das empresas em reposicionar suas marcas. Segundo o autor, pode ocorrer um envelhecimento dos produtos, marcas ou até mesmo da própria empresa, criando assim a necessidade de encontrar um novo posicionamento que tenha aderência a determinado segmento de consumidores. Esse envelhecimento pode ocorrer por puro desgaste da marca, ou em função de flutuações do mercado (RICHERS, 2000).

Oliveira (2005), acrescentando à discussão, destaca eventuais mudanças que ocorrem no ambiente empresarial, incluindo ai mudanças internas à empresa como fator preponderante no incentivo de mudanças no posicionamento da empresa. Mais tarde, Oliveira se associa a Campomar e relaciona as iniciativas de reposicionamento como um esforço da empresa em estar atenta a mudanças no mercado, sendo possível considerar este tipo de empreendimento como um sinal do nível de orientação para o mercado da empresa (OLIVEIRA e CAMPOMAR, 2006).

Já Hooley e Saunders (1998) acreditam que podem acontecer mudanças no mercado e no ciclo de vida do produto que eventualmente tornem necessária uma mudança no posicionamento atual da empresa. Por fim, Anderson e Shugan (1991) apresentam exemplo de como mudanças nas preferências dos consumidores podem afetar as empresas e o seu correspondente posicionamento.

Um exemplo dos impactos do mercado no posicionamento pode ser encontrado nas iniciativas da Avis, que resolveu mudar seu posicionamento clássico ${ }^{23}$ em função de uma estabilização no crescimento das suas vendas (PAREKH, 2008). Agora o posicionamento da Avis está sendo construído na idéia de que se deve ter um caso $^{24}$ com os carros da empresa. Outros exemplos da implementação de estratégias de reposicionamento podem ser encontrados na agricultura (BEVERLAND, 2005), nas atividades de lazer (CROMPTON, 2000), em entidades filantrópicas buscando recursos (NICHOLS, 2004) e no mercado de ensino universitário (ROY et al., 2008).

\footnotetext{
${ }^{23}$ Do inglês We Try Harder - tradução do autor.

${ }^{24}$ Do ingles Have an Affair - tradução do autor.
} 
Também Furrier e Serralvo (2006) abordam uma série de iniciativas de reposicionamento que ocorridas no mercado nacional, envolvendo marcas como Leite de Rosas, Bahia, Mastercard, CBN, Telefônica e Unimed.

Corroborando e acrescentando à discussão exposta, Telles (2004, p.73) conduz interessante revisão teórica e conclui que o reposicionamento pode ser necessário em alguns casos, como pode ser percebido nas próprias palavras do autor:

[...] a consistência de uma marca deve ser mantida preferencialmente, mas não de forma cega e irreversível; embora se deva reconhecer o risco, o custo e as dificuldades da descontinuação da consistência de um certo posicionamento de marca, mudanças de condições no ambiente (transformações na percepção do consumidor, alternações na valorização de produtos/marcas, movimentos dos concorrentes, oportunidades de expansão de mercado etc) podem determinar ou indicar essa decisão.

Telles (2004, p.78) sugere 4 situações onde surge a necessidade de colocar em prática o processo de reposicionamento:

1. Reação à perda de valor - Reposicionamento Reativo

2. Proposição de uma nova posição - Reposicionamento Propositivo

3. Correção de uma configuração de posicionamento - Reposicionamento Corretivo

4. Adaptação da comunicação do posicionamento - Reposicionamento Adaptativo

Convém, neste ponto, apresentar as considerações de Richers (2000) sobre as dificuldades de realizar o processo de reposicionamento. De acordo com o autor, este é um processo bastante árduo e que exige a participação de todos na empresa. Não é algo que pode ser idealizado e conduzido levianamente e, é claro, deve ser precedido por um extenso trabalho de segmentação para identificar para onde a empresa pode se mover no mapa mental do consumidor. Oliveira (2005, p.181) segue linha de raciocínio semelhante e considera que todo o processo de reposicionamento deve ser construído com base numa análise do público alvo da empresa, visando compreender alguns itens considerados pelo autor como fundamentais:

- Motivos que conduzem e que se colocam como barreiras ao consumo das ofertas da empresa e dos concorrentes.

- Associações realizadas 
- Nível de satisfação com o consumo da oferta da empresa e dos concorrentes

- Desejos e necessidades não atendidas pelas ofertas da empresa e dos concorrentes

- Nível de flexibilidade da aceitação de mudanças

- Potencial de consumo

A partir da análise proposta, a empresa deveria também conduzir uma avaliação interna para compreender quais são suas capacidades perante o cenário construído na análise do público alvo em relação à oferta da empresa e dos concorrentes (OLIVEIRA, 2005). Apesar do trabalho de Oliveira (2005) ter sido desenvolvido com um enfoque exclusivo para serviços, percebe-se que ele também traz algumas informações relevantes para profissionais que trabalham na área de produtos.

Furrier e Serralvo (2006, p.15) sugerem que um processo de reposicionamento seja baseado em três etapas:

a) Diagnóstico: abrange as atividades de levantamento de informações, avaliação do alvo e diagnóstico da posição de marca. Inclui as categorias de mensuração e interpretação da performance de marca, análise do cenário competitivo, segmentação de mercado, definição da categoria de produto/serviço, definição do quadro de referência do cliente, avaliação da identidade de marca e avaliação do posicionamento de marca;

b) Decisão: inclui a geração de opções e definição do conceito de reposicionamento (categorias de geração e seleção de alternativas e definição do reposicionamento);

c) Implementação: preocupa-se com a garantia da entrega da promessa de marca ao cliente e manutenção do relacionamento cliente-marca, e é compatível com as categorias de planejamento e revisão do composto de marketing, gerenciamento do relacionamento cliente-marca e comunicação do reposicionamento.

Contudo, pode-se concluir que a questão do reposicionamento é bastante complicada, pois irá tentar transformar percepções já existentes na memória dos consumidores. Essas percepções possivelmente não serão positivas, visto que a empresa visa transforma-las. Além disso, a empresa terá que trabalhar o reposicionamento de uma determinada marca dentro do seu portfolio de marcas. Caso o novo posicionamento seja muito distante do posicionamento anterior, esse esforço de mudança será ainda mais complicado. Outro complicador que pode aparecer é a transformação do modelo de negócios da empresa para atender as promessas feitas neste novo posicionamento. Resumidamente, se posicionar um produto/marca/organização já é algo complicado, reposicionar é ainda mais complexo e exigente. 


\subsection{Posicionamento no mercado infantil}

A implementação prática do posicionamento psicológico escolhido pela empresa pode ser entendida como a implementação do composto de marketing (HOOLEY e SAUNDERS, 1996). Dessa forma, esta etapa do trabalho buscará compreender as relações existentes entre o composto de marketing e o consumidor infantil. Neste sentido, serão abordadas as diferentes ferramentas de marketing que são utilizadas pelas empresas para posicionar suas marcas e produtos perante os consumidores infantis. Busca-se aqui, apresentar a literatura focada no marketing infantil, literatura esta que é predominantemente oriunda de pesquisadores focados no mercado norteamericano. Raros são os trabalhos encontrados com um enfoque no mercado brasileiro. Dessa forma, esta parte do trabalho já se configura como um valioso aporte para acadêmicos e empresas que pretendem atuar ou que atuam junto ao mercado infantil. Serão aqui abordados os seguintes tópicos referentes ao posicionamento de produtos/marcas: desenvolvimento de novos produtos, marcas e personagens, precificação, ponto de venda e comunicação.

\subsubsection{Desenvolvimento de novos produtos}

"Se você não tem um produto direcionado para as crianças, você deveria criar um logo" - As palavras ditas por um executivo de uma indústria alimentícia durante um encontro da Fundação de Pesquisa em Propaganda ${ }^{25}$, tratando sobre pesquisas focadas nas crianças consumidoras, explicam o furor da indústria de forma geral no lançamento de produtos destinados às crianças (MCNEAL, 1992, p. 181). O final da década de 80 e início da década de 90 foi palco para o lançamento de inúmeros produtos voltados para a criança:

- Revistas focadas no consumidor infantil: inúmeras empresas lançaram versões de suas publicações atuais para focar nas crianças (CROOKS, 1990). Esses lançamentos surgiram depois que a Sports Ilustrated lançou uma versão exclusiva para crianças, a Sports Ilustrated for Kids (DONATON, 1990).

\footnotetext{
${ }^{25}$ Traduzido do inglês Advertising Research Foundation - tradução do autor
} 
- Vestuário: o enorme sucesso da linha de roupas escolares lançada pela Marjani em conjunto com a Coca-Cola incentivou a empresa a buscar outros lançamentos utilizando a marca Coca-Cola (ERICKSON, 1987). Outras empresas, como o McDonals e a Searsroebuck também aderiram, lançando uma linha de roupas denominada McKids (FREEMAN, 1987)

- Comidas congeladas: diversas empresas, como a Tyson (comidas congeladas com personagens da Looney Toones) e Marry Anne Jackson (My Own Meal) obtiveram grande sucesso no mercado ao introduzir produtos específicos para as crianças (ERICKSON, 1988; FISCHER, 1989)

- Produtos dentais: a Colgate (pasta de dente mais suave e com menos espuma) e a Johnson \& Johnson (escova dental e fio dental) gastaram cerca de US\$16 milhões na introdução destes produtos focados no mercado infantil (FREEMAN, 1989; FREEMAN, 1988).

Os exemplos apresentados acima indicam uma transformação no mercado norte-americano, momento a partir do qual empresas que até então não estavam preocupadas com o mercado infantil passaram a lançar produtos com esse enfoque (MCNEAL, 1992). Se num primeiro momento os produtos eram cópias dos produtos destinados aos adultos, isso logo deixou de ser totalmente verdadeiro. $\mathrm{O}$ autor esclarece que na década de 80 foram inúmeros os produtos e serviços lançados, mas que poucos sobreviveram no mercado. Isso aconteceu porque faltou um processo de desenvolvimento de produtos que focasse em alguns fatores críticos:

- Produtos destinados às necessidades das crianças, mas pensados para obterem a aprovação dos pais.

- Produtos testados com crianças antes do seu lançamento.

- Produtos suportados por estratégias de comunicação desenhadas especificamente para as crianças. 
McNeal (1992) apresenta em sua obra o exemplo da Sports Ilustrated com o lançamento da Sports Ilustrated for Kids. A empresa evitou a armadilha de colocar os repórteres e editores existentes para criar essa nova revista, ao contrário, a revista criou toda uma nova estrutura focada no entendimento do mercado infantil. Somente dessa forma foi possível desenvolver uma revista genuinamente focada neste mercado.

A empresa pode utilizar duas estratégias principais para o desenvolvimento de novos produtos para crianças: a imitação ou a inovação (MCNEAL, 1992). A imitação está fundamentada em desenvolver produtos que já foram lançados no mercado por competidores ou em estender marcas atuais destinadas aos adultos para as crianças. Essa opção, apesar de envolver um risco financeiro menor, não permitirá que a empresa tenha grande sucesso. Em alguns casos a imitação é tão restrita que as mudanças são feitas apenas na comunicação do produto, sendo que o produto em si continua basicamente o mesmo, tanto para adultos como para crianças (MCNEAL, 1992). No entanto, a transformação de produtos para adultos em produtos para crianças era vista pelo autor como uma estratégia válida e que em alguns casos poderia trazer algum nível de sucesso para a empresa. Infelizmente para as companhias que concentraram seus esforços de lançamento de produto neste tipo de estratégia, o fracasso foi uma constante (MCNEAL, 1999).

O exemplo da Tyson com alimentos congelados destinados às crianças (FISCHER, 1989) é abordado por McNeal (1999) ainda no fim da década de 90. Ele indica que, em momentos de crise econômica, os pais deixam de comprar produtos deste tipo e, sendo assim, a Tyson abandonou este mercado. $\mathrm{O}$ autor considera que, com o crescimento econômico, alguns produtos deste tipo possam a voltar a ter algum nível de sucesso, que será mediado pela nova percepção da população norte-americana sobre valor. De acordo com o autor, as pessoas acreditam que um produto destinado às crianças deveria custar menos que o destinado aos adultos, criando assim um grande problema para as empresas que estão centradas neste tipo de desenvolvimento de produto.

A inovação traz um risco financeiro maior, inerente ao processo de criação e desenvolvimento de um produto do zero (MCNEAL, 1992). De acordo com o autor, as chances de obter um sucesso 
altamente rentável para a companhia se fazem mais presentes quando a estratégia de novos produtos está focada na inovação. Esse método é mais complexo, pois exige um esforço por parte da companhia para que as crianças e possivelmente os pais enxerguem neste produto benefícios que devem ser valorados.

Seja qual for a estratégia adotada pela empresa, é necessário atentar para a questão da aprovação dos pais (MCNEAL, 1992; MCNEAL, 1999). O autor imagina que aproximadamente $50 \%$ dos produtos vendidos para as crianças necessitam de algum tipo de aprovação. Essa aprovação é mais critica para produtos destinados a crianças abaixo dos 8 ou 9 anos (MCNEAL, 1992). A partir dessa idade, a criança passa a ter uma liberdade maior para comprar produtos e serviços (MCNEAL, 1992; MCNEAL, 1999; MCNEAL, 2007). As colocações do autor sinalizam para a necessidade de conduzir pesquisas que possam identificar o grau de aceitabilidade que o produto terá junto aos pais. Dependendo das características do produto desenvolvido para as crianças pode acontecer uma rejeição total por parte dos pais, principalmente em produtos que podem de alguma forma incomodar os adultos ou parecer custar mais do que deveria.

Uma forma de contornar esse problema é juntar os conceitos de diversão e educação no mesmo produto, de forma que tanto a criança como os pais estejam satisfeitos (MCNEAL, 1999). Para este tipo de estratégia, é tarefa da organização determinar o nível de diversão e o nível de educação que será inserido no produto. Finalmente, cabe salientar que mesmo produtos totalmente não interessantes para os pais podem trazer um apelo para a criança que fará com que o pai compre o produto, mesmo não estando satisfeito com a idéia (MCNEAL, 1999).

Ao buscar a aceitação dos pais quando desenvolvendo um produto, a companhia deve atentar para os seguintes fatores (MCNEAL, 1999):

- Felicidade: os pais querem que seus filhos sejam felizes, livres de preocupações, e de forma geral, que estejam num estado mental de felicidade. De forma geral, os pais acreditam que podem proteger seus filhos da depressão e das preocupações da vida, provendo-os com coisas que os farão felizes, ou seja, com produtos e serviços oferecidos pelas empresas. 
- Saúde: os pais se tornaram mais conscientes da sua saúde e da saúde de seus filhos. Eles aprenderam que a saúde do corpo contribui diretamente para o desenvolvimento de uma pessoa feliz. Eles querem que seus filhos tenham saúde física e mental, sendo assim, preocupam-se com a qualidade nutricional do que seus filhos consomem, assim como se preocupam com doenças que são transmitidas entre as crianças. Produtos e serviços que promovem uma melhora na saúde da criança serão mais bem aceitos.

- Preparação para a vida: os adultos querem que seus filhos estejam preparados para as dificuldades naturais da vida. Eles querem que seus filhos sejam mais bem preparados que os filhos dos outros. Uma criança feliz e com saúde não basta para os pais atualmente. Eles querem que a criança seja inteligente, astuta e mais competitiva que as outras crianças. Dessa forma os pais buscarão produtos e serviços que possam de alguma forma ajudar a criança na sua preparação para a vida, como por exemplo, lições extra-classe, aulas de música e viagens para outros países.

Os produtos destinados às crianças também podem ser pensados em termos das suas necessidades, conforme demonstra McNeal (1999, p.222):

Quadro 12 - As seis mais importantes necessidades das crianças

\begin{tabular}{|l|l|l|}
\hline \multicolumn{1}{|c|}{ 0-4 anos } & \multicolumn{1}{c|}{$\mathbf{4 - 8}$ anos } & \multicolumn{1}{c|}{ 8-12 anos } \\
\hline Sensibilidade & Brincar & Afiliação \\
\hline Brincar & Sensibilidade & Brincar \\
\hline Suporte emocional & Afiliação & Conquista \\
\hline Mudança & Conquista & Autonomia \\
\hline Afiliação & Mudança & Sensibilidade \\
\hline Exibição & Exibição & Exibição \\
\hline
\end{tabular}

FONTE: MCNEAL; 1999, p.222. 
Cabe apresentar as definições de cada uma das necessidades apresentadas por McNeal (1999):

- Conquista: conquistar alguma coisa difícil, realizar algo à semelhança dos adultos. Exemplos: negociar a compra de um produto numa loja de conveniência, preparar o próprio café da manhã no micro-ondas, participar de uma competição.

- Afiliação: ter relações cooperativas com outros, como familiares ou pares. Exemplos: participar de esportes coletivos ou jogos de tabuleiro.

- Autonomia: agir independentemente, particularmente em relação a pais ou guardiões. Exemplos: ganhar um jogo um-a-um, como os oferecidos por videogames.

- Mudança: fazer coisas novas e diferentes. Exemplos: entrar no quarto de um colega, ir a uma nova loja, comprar uma nova marca, experimentar novos sabores, sons ou visões.

- Brincar: agir com o objetivo único de se divertir, de ser entretido, divertido. Exemplos: assistir televisão, ouvir música, pular e andar de bicicleta.

- Sensibilidade: buscar e desfrutar de impressões sensórias. Exemplos: provar comidas gostosas, desenhar, colorir e brincar com a comida.

- Suporte emocional: ter o cuidado e a simpatia de outros. Exemplos: lâmpada, travesseiro ou bicho de pelúcia que trazem conforto e sentimento de proteção.

Vecchio (2002), por sua vez, trabalha o desenvolvimento de novos produtos para crianças por meio de uma matriz que envolve os seguintes fatores:

- Categoria de produto: esportes, atividades, brinquedos, snacks, restaurantes, etc. 
- Psique da criança: ganhar/dominar, controle/poder, amor/afeição, ultrajante/bobo, coragem/medos; meninas - beleza/glamour, nutrir; meninos - força/poder, bem versus mal, vulgar/bizarro.

- Características-chave/sentidos: visão, som, olfato, sabor e tato; atividade, transformação, formas/formatos, sabores.

- Mundo da criança/cultura: conhecimento do mundo, interesses, temas especiais, vida em família, animais, itens especiais/ícones, escola, esportes e lugares especiais.

- Opções de marketing: produtos/variedade, embalagem, promoções, propaganda etc.

De acordo com o autor, é necessário combinar os diversos fatores apresentados para desenvolver um produto que seja visto pelas crianças como um produto maneiro ${ }^{26}$. O produto destinado às crianças deve trazer inovações em algum dos fatores, sob pena de não conseguir atingir o status de maneiro e ser desejado pelas crianças. Um arquétipo de como as relações existentes podem transformar um produto comum numa grande novidade para as crianças pode ser encontrado na linha de ketchups coloridos lançada pela empresa Heinz nos Estados Unidos (USA TODAY, 2003). A empresa introduziu uma variedade de cores, incluindo entre as opções verde, roxo, rosa, laranja e azul, que mudaram a categoria de produto a qual o ketchup era relacionado. $\mathrm{O}$ item tornou-se objeto de desejo das crianças por transformar as refeições numa brincadeira. Esse produto utilizou diversos fatores apresentados por Vecchio (2002), como por exemplo, psique da criança (bizarro), características-chave/sentidos (visão/cores).

Lindstrom e Seybold (2003) também trabalham a questão da psique da criança como fator preponderante para o lançamento de novos produtos. De acordo com os pesquisadores, a empresa deve trabalhar os conceitos a seguir para criar produtos que sejam amplamente desejados (vide Quadro 13).

\footnotetext{
${ }^{26}$ Adaptado do inglês cool - tradução do autor.
} 
Quadro 13 - Valores chave que direcionam o sucesso do marketing para crianças

\begin{tabular}{|l|l|}
\hline Valor Chave & Explicação \\
\hline Humor & $\begin{array}{l}\text { Produtos que criam momentos divertidos e engraçados. Exemplos: Shrek, Toy Story e } \\
\text { os Simpsons. }\end{array}$ \\
\hline Medo & $\begin{array}{l}\text { Produtos que envolvam a criação de um sentimento de medo, terror, horror, pânico ou } \\
\text { guerra nas crianças. Exemplos: Monster, Inc, Tartarugas Ninja e Homem-Aranha. }\end{array}$ \\
\hline Habilidade & $\begin{array}{l}\text { Produtos que permitam que a criança demostre suas habilidades em alguma área em } \\
\text { particular. Exemplos: Lego Cam, PlayStation, X-Box e jogos de computador. }\end{array}$ \\
\hline Fantasia & $\begin{array}{l}\text { Produtos que levem a criança a participar de um mundo de fantasia, utilizando sua } \\
\text { imaginação. Exemplos: Lego, Harry Potter, Star Wars e Star Trek. }\end{array}$ \\
\hline Emor & $\begin{array}{l}\text { Produtos que envolvam o sentimento de amor. Exemplos: bonecas Barbie e bichos de } \\
\text { pelúcia. }\end{array}$ \\
\hline
\end{tabular}

FONTE: Adaptado de LINDSTROM e SEYBOLD; 2003, p.25-43.

Para Lindstrom e Seybold (2003) esses valores chave devem ser utilizados em conjunto com outros três fatores: efeito espelho (capacidade do produto em permitir que a criança faça de conta que é outra pessoa, seja ela um dos pais ou um personagem), valor de coleção (produtos, como cartas de coleção, que permitem que a criança colecione inúmeras versões do produto) e habilidade de jogo (produtos que permitem competições entre crianças para selecionar os que detêm as maiores habilidades no uso daquele determinado produto).

Utilizando outra base para a segmentação do público infantil, Acuff e Reiher (1997) dividem as características que os produtos devem ter com base na idade das crianças. Para os autores, é necessário criar produtos diferenciados para cada um dos grupos de crianças, como pode ser verificado no Quadro 14. 
Quadro 14 - O desenvolvimento da criança e os produtos mais apropriados

\begin{tabular}{|c|c|c|}
\hline & Produtos vencedores & Exemplos \\
\hline$\underset{ٍ}{ٍ}$ & $\begin{array}{l}\text { Produtos que os pais } \\
\text { imaginam que as crianças } \\
\text { precisam. Estes produtos } \\
\text { são voltados principalmente } \\
\text { para o desenvolvimento da } \\
\text { criança }\end{array}$ & $\begin{array}{l}\text { Produtos das empresas Fisher-Price e Playskool, voltados para estimular a } \\
\text { criança. Programas televisivos que envolvam animais, personagens que } \\
\text { passem a sensação de segurança, estímulos e que eduquem a criança. }\end{array}$ \\
\hline 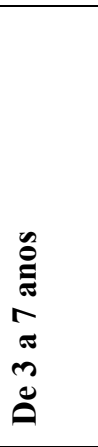 & $\begin{array}{l}\text { Produtos que foquem na } \\
\text { imaginação da criança, ou } \\
\text { seja, que permitam que a } \\
\text { criança brinque, fantasie, } \\
\text { seja surpreendida e pretenda } \\
\text { ser outro. }\end{array}$ & $\begin{array}{l}\text { Cabbage Patch Kids, Power Rangers, Figuras de Ação de heróis como } \\
\text { Batman e Barbie. Nesse período de desenvolvimento a criança não prestará } \\
\text { muita atenção ao que está escrito em uma embalagem, focando na } \\
\text { mensagem visual do pacote. Nesse período a criança ainda não está } \\
\text { preocupada com a questão de poder colecionar produtos, mas sim com o } \\
\text { acumulo de produtos (mais é melhor). Durante este período produtos que } \\
\text { trabalham as necessidades psicológicas das crianças também podem ter } \\
\text { sucesso - amor e autonomia são as necessidades mais presentes nessa faixa } \\
\text { etária. Produtos que utilizam o humor devem ser simples e diretos, visto } \\
\text { que a criança ainda não está desenvolvida o suficiente para compreender } \\
\text { jogos de palavras ou sarcasmo. }\end{array}$ \\
\hline 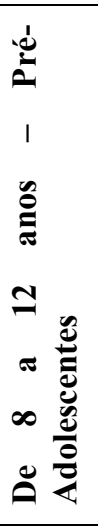 & $\begin{array}{l}\text { Durante este período de } \\
\text { desenvolvimento a criança } \\
\text { está construindo seu auto- } \\
\text { conceito e tentando se } \\
\text { inserir nos diversos grupos } \\
\text { de convivência. Produtos } \\
\text { vistos como de crianças são } \\
\text { rejeitados durante esta fase. } \\
\text { Ao se afastar de } \\
\text { determinados produtos que } \\
\text { eram adorados na fase } \\
\text { anterior a criança reafirma } \\
\text { seu crescimento. }\end{array}$ & $\begin{array}{l}\text { Durante esta fase produtos que lidam com esportes, produtos colecionáveis, } \\
\text { publicações que apresentam modelos a serem emulados, programas } \\
\text { televisivos e filmes que focam na comédia ou na ação. A criança deseja } \\
\text { produtos que a desafiem, que forneçam a base para competições, que sejam } \\
\text { complexos, que forneçam prêmios, que estimulem, que apresentem } \\
\text { variedade. Produtos que lidam com o humor passam a poder utilizar } \\
\text { abstrações e o lado negro (nojento, violento, irreverente ou tabu). Vestuário } \\
\text { se torna uma categoria importante para este grupo. A roupa e as marcas são } \\
\text { uma das formas encontradas para a criação de um auto-conceito e da } \\
\text { inserção no grupo. Produtos tecnológicos também são apreciados por este } \\
\text { grupo. Essas crianças trabalham dois aspectos psicológicos: aceitação e } \\
\text { sucesso. Produtos que permitem a aceitação em algum grupo ou uma } \\
\text { demonstração de sucesso são candidatos ao sucesso. }\end{array}$ \\
\hline 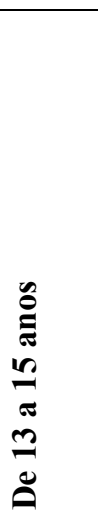 & $\begin{array}{l}\text { A questão da inserção no } \\
\text { grupo torna-se primordial. } \\
\text { A criança passa a entender } \\
\text { de forma mais complexa os } \\
\text { diferentes grupos sociais } \\
\text { que existem e tentar se } \\
\text { inserir naqueles que } \\
\text { considera mais desejados. } \\
\text { Nesta fase as marcas } \\
\text { adquirem um valor ainda } \\
\text { maior, pois o efeito de } \\
\text { consciência de marca se } \\
\text { torna cada vez mais forte. }\end{array}$ & $\begin{array}{l}\text { Produtos que trabalham a questão da marca como forma de se inserir em } \\
\text { determinado grupo tem grandes chances de serem aceitos pelos } \\
\text { adolescentes. Também são bastante procurados os produtos relacionados a } \\
\text { atividades, como esportes. Durante esta fase o adolescente está cada vez } \\
\text { mais envolvidos em atividades esportivas de grupo (basquete e vôlei). } \\
\text { Durante esta etapa buscam-se produtos que exijam mais, que sejam mais } \\
\text { complexos. Brinquedos unidimensionais ou jogos muito simples são } \\
\text { deixados de lado. Os aspectos psicológicos relevantes nesta etapa são: auto- } \\
\text { estima, identidade e sexualidade. }\end{array}$ \\
\hline
\end{tabular}

FONTE: Adaptado de ACUFF e REIHER; 1997, p. 43-123.

Seguindo a mesma linha de raciocínio de Acuff e Reiher (1997), Siegel et al. (2001) focam seu estudos em crianças entre 8 e 12 anos. Assim como aqueles pesquisadores, estes também partem das características e das necessidades psicológicas das crianças para determinar os produtos mais 
adequados para esta fase do desenvolvimento. Os fatores psicológicos abordados pelos autores são apresentados a seguir:

- Poder: envolve o controle e a habilidade de participar, também envolve a questão de tomar decisões em algum contexto social. O pré-adolescente objetiva tomar controle de uma situação, de alguém ou de algo, por isso propagandas que trazem o pré-adolescente como sendo mais esperto que um adulto tem grande sucesso.

- Liberdade: o pré-adolescente passa por um período de transição, sendo que ao mesmo tempo em que ainda necessita da segurança provida pelos pais, ele deseja liberdade e independência. Produtos como acesso a internet e telefones celulares serão bem vistos, pois proporcionam liberdade.

- Diversão: para este grupo a diversão está associada com momentos onde existe a ausência de medo, tristeza e trabalho. Produtos como comidas em formas de animais, brinquedos básicos, brinquedos que enojam os adultos e jogos de palavras são desejados.

- Fazer parte: é um dos direcionadores mais fortes deste grupo etário. Produtos que trabalhem a necessidade do pré-adolescente de fazer parte serão aceitos.

Ainda, Siegel et al. (2001) expandem sua análise sobre o que direciona as atividades de consumo deste grupo etário, conforme pode ser observado no Quadro 15. 
Quadro 15 - Motivadores Centrais dos Pré-adolescentes

\begin{tabular}{|c|c|c|c|}
\hline Necessidade & $\begin{array}{l}\text { Plataforma } \\
\text { Motivacional }\end{array}$ & $\begin{array}{l}\text { Motivador } \\
\text { Central }\end{array}$ & Explicação \\
\hline \multirow{4}{*}{ Pessoal } & Fazer Parte & $\begin{array}{l}\text { Valor } \\
\text { Familiaridade }\end{array}$ & $\begin{array}{l}\text { Produtos que valorizam a criança, que mostram que ela } \\
\text { pode fazer diferença. }\end{array}$ \\
\hline & Poder & $\begin{array}{l}\text { Habilidade } \\
\text { Inteligência } \\
\text { Rebeldia }\end{array}$ & $\begin{array}{l}\text { Produtos que possibilitem que a criança atinja um } \\
\text { objetivo, que exceda numa tarefa ou que mostre } \\
\text { proficiência em determinado campo. }\end{array}$ \\
\hline & Liberdade & $\begin{array}{l}\text { Individualidade } \\
\text { Único } \\
\text { Independência }\end{array}$ & $\begin{array}{l}\text { A criança ainda continua dependente dos pais, mas ao } \\
\text { mesmo tempo necessita mostrar sua independência. } \\
\text { Também é importante salientar a questão da busca de } \\
\text { modelos e exemplos em grupos de idade superior, pois } \\
\text { essas crianças não querem ser vistas como crianças, por } \\
\text { isso querer demonstrar serem mais velhas. }\end{array}$ \\
\hline & Diversão & $\begin{array}{l}\text { Imaginação } \\
\text { Simplicidade } \\
\text { Sensação }\end{array}$ & $\begin{array}{l}\text { A criança passa por uma fase onde tudo ainda é possível, } \\
\text { onde os limites estão sendo descobertos e por isso esta } \\
\text { etapa do desenvolvimento é cheia de excitação, desafios e } \\
\text { questões intrigantes. Produtos que dêem vazão a essa } \\
\text { imaginação, como jogos eletrônicos (X-Box, Nintendo e } \\
\text { PlayStation) e livros de fantasia (Harry Poter) terão um } \\
\text { grande apelo. }\end{array}$ \\
\hline \multirow{4}{*}{ Social } & Fazer Parte & $\begin{array}{l}\text { Popularidade } \\
\text { Amizade } \\
\text { Assimilação }\end{array}$ & $\begin{array}{l}\text { Popularidade, nesta etapa, significa ser aceito pelo maior } \\
\text { número de outros pré-adolescentes. Grupos de referência } \\
\text { se tornam cada vez mais significativos e produtos que } \\
\text { utilizam este apelo de popularidade ou fazer parte de um } \\
\text { grupo terão sucesso. }\end{array}$ \\
\hline & Poder & $\begin{array}{l}\text { Superioridade } \\
\text { Controle } \\
\text { Amor }\end{array}$ & $\begin{array}{l}\text { O sucesso de personagens como o Super-homem estão } \\
\text { baseados no nível de superioridade que ele possui. A } \\
\text { criança nesta fase busca demonstrar seu valor sendo } \\
\text { superior em algum campo. Uma forma de atingir essa } \\
\text { superioridade é ser o primeiro do grupo a possuir } \\
\text { determinado produto, essa idéia explica as corridas que } \\
\text { ocorrem às lojas para comprar produtos recém lançados, } \\
\text { como vídeo games (Nintendo Wii) e livros (Harry } \\
\text { Potter). }\end{array}$ \\
\hline & Liberdade & $\begin{array}{l}\text { Imitação } \\
\text { Exploração }\end{array}$ & $\begin{array}{l}\text { Estrelas do cinema e da música direcionam o consumo } \\
\text { destas crianças, não porque a criança quer realmente ser } \\
\text { uma estrela de cinema, mas sim porque ela deseja fazer } \\
\text { parte de um grupo que adora ou cultua determinado } \\
\text { grupo ou pessoa. Dessa forma, este direcionador explica } \\
\text { a venda de produtos que permitem que a criança se } \\
\text { coloque como admirador e imitador de um ator ou } \\
\text { músico famoso. }\end{array}$ \\
\hline & Diversão & $\begin{array}{l}\text { Divertimento } \\
\text { Criatividade }\end{array}$ & $\begin{array}{l}\text { Quando uma criança diz que está apenas se divertindo ela } \\
\text { explica este direcionador. A criança passa por momento } \\
\text { onde o grupo está envolvido em alguma atividade, que } \\
\text { apesar de não ter um objetivo central, é divertida. }\end{array}$ \\
\hline
\end{tabular}

FONTE: SIEGEL et al.; 2001, p.51.

Siegel et al. (2001) apresentam no Quadro 16 os maiores interesses de crianças entre 8 e 12 anos, certamente um bom ponto de partida para o desenvolvimento de novos produtos. Esses interesses 
seguem a lógica das necessidades de afiliação apresentadas anteriormente, principalmente no grupo masculino.

Quadro 16 - Maiores interesses das crianças entre 8 e 12 anos

\begin{tabular}{|l|l|}
\hline Meninas entre 8 e 12 anos & Meninos entre 8 e 12 anos \\
\hline Música & Participar em esportes \\
\hline Natureza e animais & Assistir esportes \\
\hline Pessoas famosas & Natureza e animais \\
\hline Artes e ofícios & Música \\
\hline Moda & Ciência \\
\hline Dança & Pessoas famosas \\
\hline
\end{tabular}

FONTE: SIEGEL et al.; 2001, p.79.

Ainda compartilhando dos mesmos princípios dos autores supracitados, Montigneaux (2003) traz no Quadro 17 interessantes considerações sobre os itens que são de interesse da criança ao longo do seu crescimento.

\begin{tabular}{|l|l|l|l|}
\multicolumn{1}{l|}{ Quadro 17 - Centros de interesse da criança } \\
\hline & $\begin{array}{c}\text { Níveis de } \\
\text { idade }\end{array}$ & \multicolumn{1}{|c|}{ Centros de interesse } & \multicolumn{1}{c|}{ Palavras-chave } \\
\hline Recém nascidos e lactentes & $0-24$ meses & & Higiene, segurança, limpeza \\
\hline Crianças na tenra infância & $2-4$ anos & $\begin{array}{l}\text { Casulo familiar: quarto de } \\
\text { jogos, contos }\end{array}$ & $\begin{array}{l}\text { Carinho, afeto, doçura, proteção, } \\
\text { tranqüilidade, atenção }\end{array}$ \\
\hline $\begin{array}{l}\text { Crianças na idade pré- } \\
\text { escolar }\end{array}$ & $4-6$ anos & $\begin{array}{l}\text { Televisão (desenhos } \\
\text { animados) }\end{array}$ & Imaginário, magia, aventura, animais \\
\hline Juniores & $6-9$ anos & Televisão (jogos de vídeo) & Conhecimento, coleções, trocas \\
\hline Pré-adolescentes & $9-11$ anos & $\begin{array}{l}\text { Internet, vestuário, música, } \\
\text { televisão }\end{array}$ & Rejeição da infância, moda, tribos \\
\hline
\end{tabular}

FONTE: MONTIGNEAUX; 2003, p.101.

De posse das informações apresentadas pelo autor, a empresa pode desenvolver produtos, criar marcas, criar personagens e apelos que sejam direcionados para aqueles temas que são mais importantes para a criança na faixa etária em que ela se encontra.

Outra preocupação que as empresas devem ter no desenvolvimento de produto relaciona-se ao design do produto. Fishel (2001) identifica três categorias que deveriam ser abordadas ao criar o design de um novo produto: desenvolvimento cognitivo e social, habilidades sociais e desenvolvimento físico e motor. Abaixo a autora oferece maiores explicações sobre cada um dos temas: 
- Desenvolvimento cognitivo e intelectuall: capacidade da criança em lidar com o uso de palavras e regras, complexidade do brinquedo, memória etc.

- Habilidades sociais: o grau capacidade da criança em partilhar a experiência do brinquedo com outros.

- Desenvolvimento físico e motor: o nível de habilidade da criança em determinado momento do seu desenvolvimento e a adequação dos brinquedos a este nível. Trata de questões como: equilíbrio, manipulação de materiais, coordenação etc.

Partindo do que foi apresentado até então é possível resumir as escolhas da empresas em algumas linhas gerais:

1. Determinar qual estratégia de desenvolvimento de novos produtos irá utilizar: inovação versus imitação. Cada uma das estratégias apresenta riscos, dificuldades e vantagens diferentes. Cabe a empresa determinar qual o caminho que escolherá trilhar no desenvolvimento de produtos para o mercado infantil.

2. Selecionar dentre as diversas necessidades que as crianças apresentam para criar um produto ou serviço realmente adequado para esse grupo de consumidores. Com base nas diversas análises da psicologia da criança, é possível compreender melhor como os diversos atributos, que podem ser agregados a um produto ou serviço, atuam satisfazendo a criança.

3. Ter um cuidado especial com relação ao design do produto. Dependendo da faixa etária da criança, ela pode não ter a capacidade de manipular ou até mesmo compreender, alguns produtos em função de limitações físicas ou psicológicas.

\subsubsection{Marcas e personagens}

Outro atributo fundamental na escolha de produtos pelos consumidores, a marca e, marcadamente no público infantil, as personagens, ganharam destaque nas palavras de Montigneaux (2003). O pesquisador relaciona a idade da criança com a influência que ela sofre das marcas. $\mathrm{O}$ autor 
utiliza a questão da idade, pois considera que é uma das características da criança que mais representa possibilidades de segmentação. Isso decorre da relação existente entre o crescimento da criança e seu desenvolvimento físico e psicológico, itens que estão intimamente relacionados à idade da criança. Montigneaux (2003, p.67-74) apresenta de forma mais completa essa relação entre a idade da criança e os fatores influenciadores:

Quadro 18 - O desenvolvimento das capacidades cognitivas da criança e seu entendimento das marcas

\begin{tabular}{|c|c|}
\hline Idade & Principais fatores \\
\hline $\begin{array}{l}\text { Entre } 0 \text { e } 2 \\
\text { anos }\end{array}$ & $\begin{array}{l}\text { Avaliação e comparação de marcas e produtos } \\
\text { - O egocentrismo da criança a impede de representar qualquer objeto sob diferentes ângulos. } \\
\text { - O produto não é entendido segundo seus atributos físicos, mas a partir de experiências sensoriais e } \\
\text { motrizes da criança. } \\
\text { - Ela observa aquilo que o objeto faz se ela exerce sobre ele uma ação. } \\
\text { - A criança poderá entender o produto se ela puder tocá-lo, manipula-lo e se tiver um } \\
\text { relacionamento sensorial com ele. }\end{array}$ \\
\hline $\begin{array}{l}\text { Entre } 2 \text { a } 3 \\
\text { e } 6 \text { a } 7 \text { anos }\end{array}$ & $\begin{array}{l}\text { Avaliação e comparação de marcas e produtos } \\
\text { - Até os } 4 \text { anos: o aprendizado sobre o produto continua sendo basicamente sensorial. Até este } \\
\text { momento a criança compara produtos com base em apenas um critério por vez. } \\
\text { - A partir dos } 5 \text { a } 6 \text { anos a comparação entre os produtos se faz por atributos mais abstratos. - Os } \\
\text { critérios relacionados ao aspecto físico continuam valendo, mas a criança passa a relacionar outros } \\
\text { critérios na sua avaliação de um produto. } \\
\text { - Reconhecimento do nome da marca } \\
\text { - A associação de uma marca a um produto é um processo progressivo, relacionado ao } \\
\text { desenvolvimento cognitivo da criança e com o aprendizado leitura. } \\
\text { - A partir dos } 4 \text { a } 5 \text { anos a criança passa a reconhecer o nome da marca a partir dos seus elementos } \\
\text { (logo, formato da palavra, presença de uma letra conhecida). Nessa idade é comum a criança } \\
\text { cometer erros ao escrever o nome de uma marca. } \\
\text {-A partir dos } 6 \text { anos as crianças passam a saber os nomes de marcas relacionadas as diferentes } \\
\text { categorias de produto, porém esses nomes servem mais para identificar a categoria de produto do } \\
\text { que como uma forma de expressar uma determinada predileção por uma marca em particular. }\end{array}$ \\
\hline $\begin{array}{l}\text { Faixa dos } 7 \\
\text { anos }\end{array}$ & $\begin{array}{l}\text {-A partir desta idade as criança começam a ter uma melhor compreensão das marcas e sua } \\
\text { finalidade comercial. } \\
\text {-A criança passa a entender a diferença entre produto e marca. } \\
\text {-A criança passa a ter predileção por algumas marcas em determinadas categorias de produto que } \\
\text { lhe são mais próximas, como por exemplo cereais matinais. }\end{array}$ \\
\hline $\begin{array}{l}\text { Entre } 7 \text { e } 11 \\
\text { anos }\end{array}$ & $\begin{array}{l}\text { Avaliação e comparação de marcas e produtos } \\
\text {-A partir dos } 7 \text { anos, com o domínio da reflexão, o raciocínio toma conta. } \\
\text {-A criança consegue hierarquizar, sintetizar e conceitualizar as marcas. } \\
\text {-Ela enriquece sua percepção sobre os diferentes produtos e marcas. } \\
\text {-O reconhecimento do nome da marca se torna bastante presente. }\end{array}$ \\
\hline
\end{tabular}

FONTE: Adaptado de MONTIGNEAUX; 2003, p. 67-74.

O Quadro 18 permite compreender melhor a relação da criança com as marcas. O primeiro item a ser destacado do quadro é a incapacidade da criança, nos seus primeiros anos de vida, em analisar mais de um atributo do produto. Essa situação deve ser analisada pelas empresas que estão desenvolvendo comunicações direcionadas para as crianças, facilitando e apresentando de forma 
clara aquele atributo que lhe é mais favorável para que a criança tome sua decisão com base neste fator em particular.

Destaca-se também, a incapacidade da criança, até por volta de 6 anos de idade, em separar uma marca de uma categoria de produto. Essa criança irá requisitar uma marca em particular, mas na realidade estará apenas fazendo referência a categoria de produto a qual aquela marca pertence. Empresas que tiverem sucesso em ser essa marca de referência para aquela categoria de produto certamente serão alvo de um número mais de pedidos de compra por parte das crianças.

Para que uma criança compreenda o significado de uma marca no seu nível simbólico ou conceitual é necessário que ela preencha 3 pré-requisitos (ACHENREINER e JOHN, 2003, p.206).

1. Primeiro, as crianças precisam reconhecer os nomes de marca como uma forma de identificar um produto específico dentro de uma categoria de produto.

2. Segundo, as crianças devem reconhecer o nome da marca como um elemento único e separado do produto, distinto da embalagem e do produto em si. A criança deve ser capaz de decompor um determinado produto em dimensões separadas e distintas, vendo o nome da marca como um dos elementos separados.

3. Terceiro, uma vez que a criança é capaz de reconhecer uma marca como um elemento separável do produto, elas devem ser capazes de pensar sobre o nome da marca num nível abstrato, conectando o nome da marca à características não observáveis ou associações como qualidade, prestigio e estar na moda.

Crianças que ainda não compreenderam a marca no seu nível simbólico irão entender a marca somente no nível perceptual, ou seja, apenas entenderão a marca como familiar ou associada com alguma característica perceptual (ACHENREINER e JOHN, 2003). O processo de incorporação das características simbólicas na percepção da marca inicia-se por volta dos 8 anos e se completa por volta dos 12 anos (ACHENREINER e JOHN, 2003). A partir dessas considerações é possível 
compreender que iniciativas de construção de marca no nível simbólico, se realizadas para segmentos compostos por crianças com idade inferior aos 8 anos, serão infrutíferas.

De acordo com Keller e Machado (2006), de cada 10 novos produtos lançados no mercado, apenas 1 ou 2 terão sucesso. Essa é uma das razões que impulsiona atividades de extensão de marca, ou seja, o uso de uma marca existente para novos produtos (KELLER e MACHADO, 2006). O uso de extensões de marca também cria a possibilidade da diminuição dos custos de introdução de um novo produto e o aumento das possibilidades de sucesso desta novidade ao carregar uma marca que facilite a aceitação de consumidores e varejistas (KELLER e AAKER, 1992). Achenreiner e John (2003) verificam que crianças com idade ao redor dos 8 anos apresentam uma percepção favorável para todo o tipo de extensão de marca, tanto extensões próximas como distantes. Já as crianças com idade próxima aos 12 anos, fazem uma diferenciação entre as extensões próximas e distantes, tendo uma visão mais favorável das extensões próximas.

Para melhor compreender o processamento de informações entre os infantes, Macklin (1996) desenvolveu trabalho buscando verificar como o uso de pistas visuais afeta a lembrança de marca de crianças em idade pré-escolar. Os resultados da sua pesquisa apresentam algumas considerações confirmadas posteriormente por Montigneuax (2003). Macklin (1996) coloca que uma empresa pode agregar algumas pistas visuais (uma figura ou cor) para melhorar a lembrança de suas marcas. Porém, a autora esclarece que o uso de mais de duas pistas vai além da capacidade de processamento da criança, já que nesse estágio etário, a criança apenas reconhece as marcas no seu nível perceptual, impossibilitando correlações mais avançadas entre as pistas, conforme supracitado nas palavras de Achenreiner e John (2003).

No Quadro 17, Montigneaux (2003) expõe que a criança com cerca de 5 anos de idade tem uma relação unidimensional com os produtos, ou seja, somente consegue utilizar um atributo para fins de comparação. Macklin (1996) estende então essa colocação para as marcas, deixando claro que a criança ainda não desenvolveu a capacidade de utilizar diversas informações de forma simultânea. Com base no que foi apresentado, é possível entender que deve haver uma preocupação por parte das empresas em desenvolver marcas e logotipos que sejam mais simples 
para faixas etárias mais novas. Isso irá aumentar as chances do reconhecimento e lembrança da marca.

Acrescentando à discussão sobre pistas visuais, marcas e processamento de informações entre crianças, Veloso e Hildebrand (2007) coletaram desenhos com crianças da alta renda (8 a 9 anos de idade), verificando que nessa faixa etária a criança já consegue escrever o nome das marcas e representar os símbolos. Na Ilustração 17 são apresentados dois exemplos, onde crianças conseguiram representar claramente o logotipo do McDonalds e a grafia da Daslu.

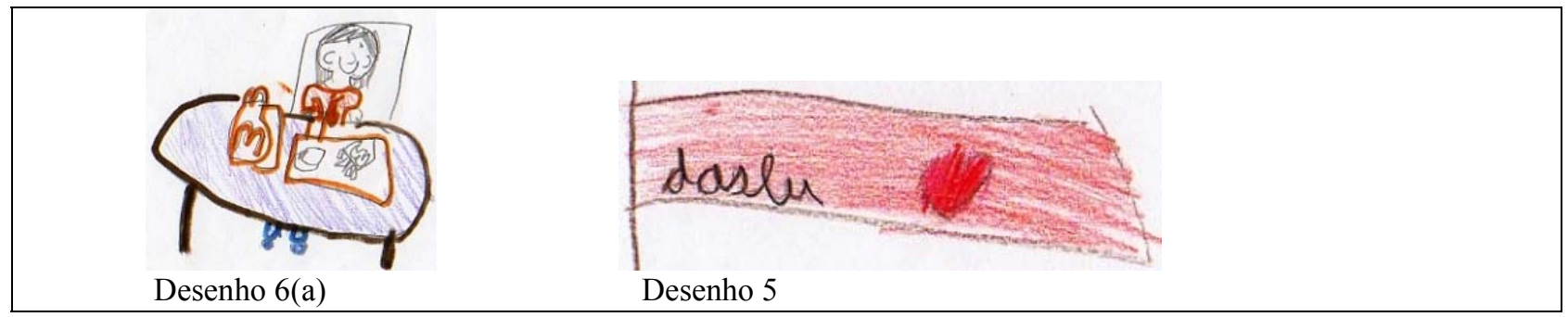

Ilustração 17 - Satisfação e afeto no consumo FONTE: Adaptado de VELOSO e HILDEBRAND; 2007, p. 12.

Já na Ilustração 18, percebe-se que as crianças conseguiram representar parcialmente o logo da empresa de brinquedos Rihappy, porém a grafia do nome da empresa apareceu de forma equivocada em algumas ocasiões: Hihappy, Rihappi, Hihappig, Hihapi e Rirepe. Fishel (2001) indica que crianças na faixa etária dos 8 ou 9 anos já estão numa fase do desenvolvimento em que estão aptas a ler, mas ainda precisam de pistas visuais em conjunto com o texto. Somente a partir dos 10 anos, complementa a autora, é que as crianças conseguem ter uma capacidade mais desenvolvida para entender logotipos e marcas mais complexas. A sugestão que Veloso e Hildebrand (2007) deixam é direcionada para o desenvolvimento de logos e nomes de marcas mais simples, principalmente para empresas que trabalham com um público infantil abaixo dos 10 anos. 


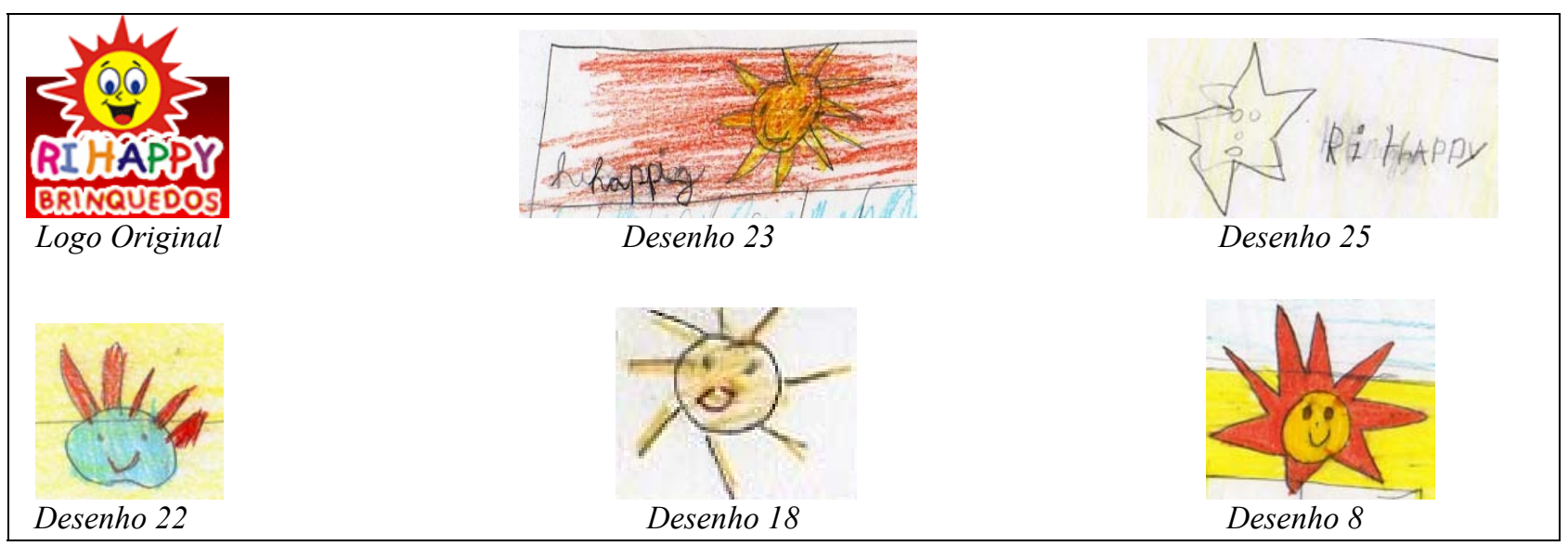

Ilustração 18 - Ri-Rappy: Original Vs Desenhos FONTE: VELOSO e HILDEBRAND; 2007, p. 12.

As empresas já fazem uso de personagens para comunicar seus produtos há muito tempo. Exemplos do início da década de 90 fundamentam essa colocação:

- Uso dos personagens Jetsons para promocionar empresas de fast-food e alimentos embalados (FITZGERALD e LIESSE, 1990).

- Uso dos personagens Looney Toones para promocionar refeições congeladas ( $t v$ dinner) produzidas pela Tyson Foods (GARFIELD, 1990).

- A marca de refrigerantes Seven-Up lança um personagem animado, chamado Spot, para ser o porta-voz da empresa. As propagandas com o personagem serão colocadas nos sábados de manha, buscando criar uma ligação da criança com a marca para gerar uma leva de heavy-users (LAWRENCE, 1987).

- A Nintendo lança o primeiro vídeo-game com um personagem da propaganda, no caso o porta-voz da Seven-Up denominado Spot (LAWRENCE e FITZGERALD, 1990).

- A empresa de cereais matinas Kellogg's lança um personagem animado chamado Bigg Mixx, investindo U\$30 milhões no seu lançamento (LIESSE, 1990).

Nesse sentido, Montigneuax (2003, p.104) afirma que

[o]s personagens imaginários são uma parte absorvente do universo da criança. Tem por origem domínios extremamente diversos. Saem das histórias contadas pelos pais e pelos avós, dos filmes, dos desenhos animados, do universo dos desenhos em quadrinhos ou dos produtos de grande consumo. 
É interessante observar na abordagem do autor que para as crianças existe o conceito de o personagem estar na moda, já que personagens fora da moda são evitados pelas crianças por, inseridas no contexto escolar, buscarem a inserção e a aceitação de grupos de colegas (MONTINGEAUX, 2003). A colocação do cientista refere-se a crianças em idade escolar, ou seja, a partir dos 6 anos. Esses personagens, complementa ainda, ficam na moda entre 6 e 18 meses.

Quadro 19 - Os tipos de personagens

\begin{tabular}{|c|c|c|}
\hline & Personagem "Aventureiro" & Personagem "social" \\
\hline $\begin{array}{l}\text { Motivos de escolha da criança } \\
\text { (personagem escolhido como } \\
\text { modelo) }\end{array}$ & $\begin{array}{l}\text { Que ousa, } \\
\text { Que é bem sucedido, } \\
\text { Justiceiro }\end{array}$ & $\begin{array}{c}\text { Sorridente, } \\
\text { Bom exemplo, } \\
\text { Bom ator, } \\
\text { Célebre, } \\
\text { Feliz }\end{array}$ \\
\hline \multirow[t]{2}{*}{$\begin{array}{l}\text { Atributos de personalidade do } \\
\text { herói, importantes para a } \\
\text { criança }\end{array}$} & \multicolumn{2}{|l|}{$\begin{array}{l}\text { Corajoso, } \\
\text { Astuto, } \\
\text { Audacioso, } \\
\text { Eficiente, } \\
\text { Exótico, }\end{array}$} \\
\hline & $\begin{array}{l}\text { Inteligente, } \\
\text { Forte, } \\
\text { Ágil, } \\
\text { Sem defeitos }\end{array}$ & $\begin{array}{l}\text { Gentil, } \\
\text { Bom, } \\
\text { Sábio } \\
\text { Belo }\end{array}$ \\
\hline Síntese & $\begin{array}{l}\text { Esse personagem tem um projeto e é } \\
\text { na ação que se ele se realiza aos } \\
\text { olhos da criança. } \\
\text { Ele possui atributos adultos e, } \\
\text { sobretudo, masculinos, } \\
\text { Os atributos físicos do personagem } \\
\text { são pouco descritos e o corpo é } \\
\text { reproduzido pela criança "na sua } \\
\text { função instrumental de ferramenta } \\
\text { bem adaptada à ação". }\end{array}$ & $\begin{array}{l}\text { Esse personagem atrai as crianças por } \\
\text { que é (engraçado, sorridente etc.) ou } \\
\text { por que tem (felicidade, por } \\
\text { exemplo). } \\
\text { Ele possui atributos infantis e, } \\
\text { sobretudo, femininos. O corpo do } \\
\text { personagem é apreciado pela criança } \\
\text { do ponto de vista estético e como } \\
\text { "meio de expressão e suporte de } \\
\text { valor". }\end{array}$ \\
\hline
\end{tabular}

FONTE: LAUWE e BELLAN; 1979 apud MONTIGNEAUX; 2003, p. 109.

Montigneaux (2003) traz duas considerações gerais sobre o quadro apresentado (marcados como 1 e 2 na parte que fala sobre os atributos de personalidade do herói):

1. Esses atributos são fortemente opostos entre si. "Corajoso", por exemplo, é super-representado no personagem "aventureiro" e sub-representado no 
personagem "social". Da mesma maneira, "artista", é super representado no personagem "social" e sub-representado no personagem "aventureiro".

2. Esses atributos são super-representados para cada tipo de personagem sem serem sub-representados pelo tipo oposto.

Este tópico abordou a questão das marcas, logotipos e personagens. Todas formas de apresentar a oferta da empresa para a criança. Sugestões interessantes foram apresentadas, no sentido de trabalhar as capacidades da criança durante o desenvolvimento de marcas e logotipos. Também foi possível compreender a função dos personagens como um item que liga a marca à criança.

\subsubsection{Questões relativas à precificação e o consumidor infantil}

Encerrando o instrumento de posicionamento centrado no produto, parte-se para os demais 3 Ps do composto de marketing, inciando pelas estratégias de precificação como forma de posicionamento perante o público infantil. A primeira idéia a ser trabalhada quando se trata da precificação e o mercado infantil é a noção de que as crianças nem sempre serão os pagantes daqueles produtos ou serviços que consomem (MCNEAL, 1999). Em grande parte das ocasiões de consumo, pelo menos até os 8 anos de idade, o pagamento será realizada pelos pais. Essa situação faz com que algumas empresas considerem que as crianças não apresentam preocupações sobre o preço das coisas. Desenhos coletados por Veloso e Hildebrand (2007), com crianças oriundas da classe A, apontam para uma criança entre 8 e 9 anos, que apenas começa a perceber a participação do preço no ambiente de consumo.

Nagle e Holden (2005) sugerem que a empresa avalie três fatores antes da determinação do seu preço final: custos de produção, preços cobrados pela concorrência e a percepção dos consumidores sobre o valor daquilo que a empresa oferece. A idéia apresentada por McNeal (1999), que diz que nem sempre a criança é a pagadora, aponta para a necessidade da empresa compreender qual o papel da criança e dos pais no processo de compra, com especial atenção ao momento do pagamento, pois é somente assim que a empresa terá a perfeita avaliação dos fatores apresentados por Nagle e Holden (2005). 
Tabela 3 - Renda, gastos e economias médias semanais de crianças, de acordo com a idade, em 1984 e 1989

\begin{tabular}{|l|l|l|l|l|l|l|}
\hline & \multicolumn{3}{|l|}{ Renda } & \multicolumn{2}{l|}{ Gastos } & Economias \\
\hline Idade & $\mathbf{1 9 8 4}$ & $\mathbf{1 9 8 9}$ & $\mathbf{1 9 8 4}$ & $\mathbf{1 9 8 9}$ & $\mathbf{1 9 8 4}$ & $\mathbf{1 9 8 9}$ \\
\hline $\mathbf{4}$ & $\$ 1,08$ & $\$ 1,78$ & $\$ 0,49$ & $\$ 0,83$ & $\$ 0,59$ & $\$ 0,95$ \\
\hline $\mathbf{5}$ & 1,12 & $\$ 1,98$ & $\$ 0,90$ & $\$ 1,31$ & $\$ 0,22$ & $\$ 0,67$ \\
\hline $\mathbf{6}$ & 1,28 & $\$ 2,71$ & $\$ 1,25$ & $\$ 1,98$ & $\$ 0,03$ & $\$ 0,73$ \\
\hline $\mathbf{7}$ & 1,85 & $\$ 3,12$ & $\$ 1,80$ & $\$ 2,59$ & $\$ 0,05$ & $\$ 0,53$ \\
\hline $\mathbf{8}$ & 2,50 & $\$ 3,41$ & $\$ 2,31$ & $\$ 2,66$ & $\$ 0,19$ & $\$ 0,75$ \\
\hline $\mathbf{9}$ & 3,52 & $\$ 4,83$ & $\$ 3,19$ & $\$ 3,20$ & $\$ 0,33$ & $\$ 1,63$ \\
\hline $\mathbf{1 0}$ & 4,05 & $\$ 4,88$ & $\$ 3,39$ & $\$ 3,28$ & $\$ 0,66$ & $\$ 1,60$ \\
\hline $\mathbf{1 1}$ & 4,79 & $\$ 7,69$ & $\$ 4,33$ & $\$ 5,05$ & $\$ 0,46$ & $\$ 2,64$ \\
\hline $\mathbf{1 2}$ & 5,49 & $\$ 9,83$ & $\$ 5,26$ & $\$ 6,90$ & $\$ 0,23$ & $\$ 2,94$ \\
\hline
\end{tabular}

FONTE: MCNEAL; 1992, p.26.

$\mathrm{Na}$ Tabela 3 são apresentados os valores envolvidos com os gastos, com as economias e a renda de crianças entre 4 e 12 anos. Percebe-se que existe uma vontade da criança, seja qual for a idade, em gastar sua renda com determinados produtos e serviços, assim como uma iniciativa no sentido de economizar para alguma compra mais custosa. McNeal (1999) indica que uma criança média norte-americana possui cerca de 20 ou 30 dólares guardados no quarto e algumas centenas de dólares no banco, guardados para uma compra mais significativa. De acordo com McNeal (1992), a fonte dessa renda pode ser dividida da seguinte forma: mesada (53\%), tarefas domésticas $(15 \%)$, presentes de parentes $(15 \%)$, trabalho $(12 \%)$ e presentes de outros $(5 \%)$.

Dados referentes a crianças com idade entre 8 e 12 anos são apresentados por Siegel et al. (2001), trazendo um maior aprofundamento no tema. De acordo com os autores, $85 \%$ das crianças recebem dinheiro em ocasiões especiais (aniversário, fada do dente, etc), 75\% recebem dinheiro realizado tarefas domésticas, 70\% recebem presentes em dinheiro, 17\% vendendo produtos e 11\% cuidado de outras crianças. A Ilustração 19 traz maiores informações sobre o nível de renda das crianças, traçando uma comparação entre crianças da alta renda e as outras crianças. 


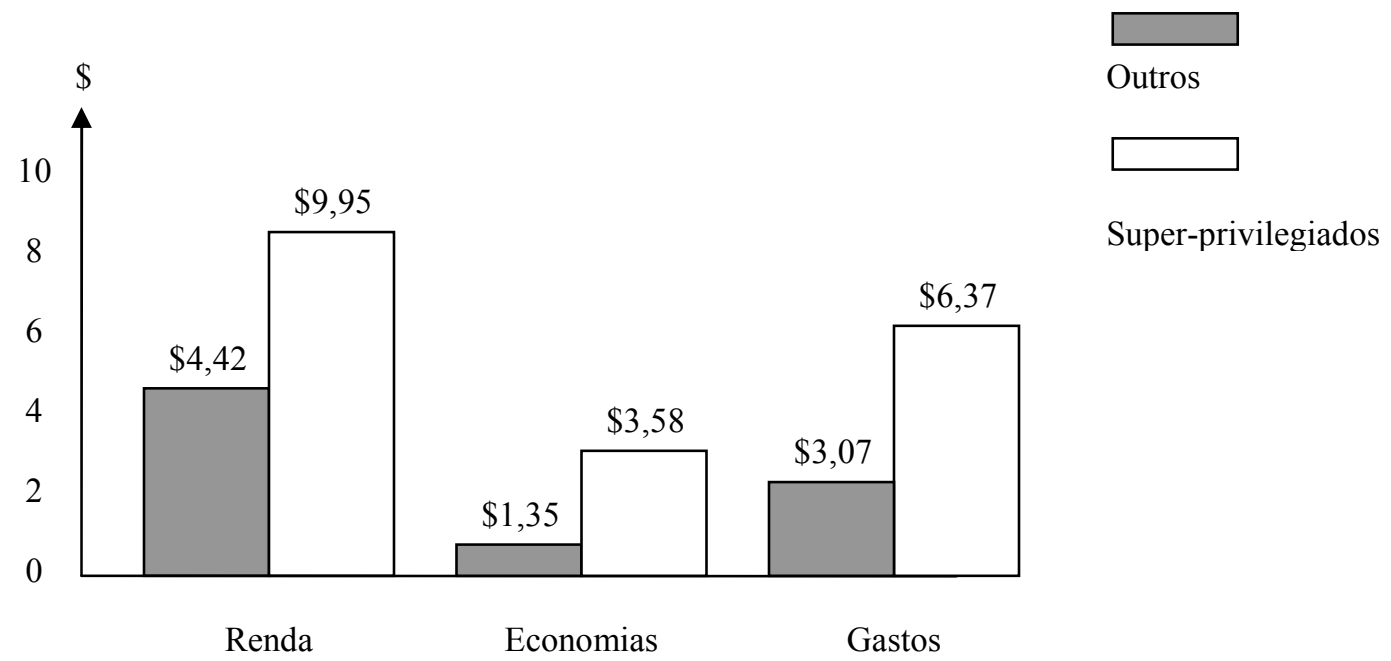

\section{Ilustração 19 - Renda, economias e gastos médios semanais das crianças super-privilegiadas comparadas às outras crianças. FONTE: MCNEAL; 1922, p33.}

Os dados apresentados fundamentam a colocação de McNeal (1992; 1999; 2007) sobre o conceito de mercado infantil tridimensional, ou seja, que a criança influencia compras, é um futuro consumidor e é um consumidor atual, com renda e com disposição para gastar. O problema é que as empresas são lideradas por adultos que muitas vezes não compreendem muito bem a relação da criança com o dinheiro (MCNEAL, 1992). Dessa forma, faz-se necessário estabelecer linhas de pesquisa que tenham como centro a criança como consumidora e como pagadora dos produtos que adquire.

Os infantes começam a aprender o conceito de preço por volta dos 5 anos (MCNEAL, 1999). De acordo com o autor, é nessa época que o indivíduo faz suas primeiras compras com a ajuda dos pais. Veloso e Hildebrand (2005), ao realizarem pesquisa de observação num supermercado de baixa renda da Grande São Paulo, identificaram que são inúmeras as iniciativas dos pais no sentido de ensinar os rudimentos do consumo. Nesse sentido, acredita-se que entre os 5 e os 8 anos a criança passa por um processo de aprendizado do que significa consumir. $\mathrm{O}$ conhecimento sobre o preço dos produtos foi analisado por diversos autores como um das preocupações da escola no aprendizado do consumo e como uma das formas encontradas para medir o nível de socialização da criança como consumidora (STAMPFL et al., 1978; MOSCHIS e MOORE, 1978; e STEPHENS e MOORE, 1975). 
De forma resumida, é possível afirmar que o aprendizado, do conceito de preço, ocorre por duas vias principais: aulas no contexto escolar e esforços dos pais para ensinar aos filhos os rudimentos do consumo. Talvez fosse necessário um maior esforço por parte dos profissionais de marketing no sentido de trabalhar esse aprendizado junto ao seu público, permitindo assim que a criança seja mais bem informada e tome decisões melhores.

Seguindo o mesmo caminho, McNeal (1999) aborda a questão da percepção das crianças sobre o preço e afirma que as crianças, principalmente as mais velhas, têm uma visão negativa do mesmo. Isso acontece por que:

- O preço faz com que elas não consigam comprar algumas coisas com seu próprio dinheiro.

- O preço é uma justificativa para os pais não comprarem coisas para elas.

- Em algumas ocasiões os pais reclamam e discutem sobre o preço dos produtos e serviços.

- É algo que os vendedores tentam esconder.

Com relação à sensibilidade a preço das crianças, McNeal (1999) verifica que houve uma drástica mudança ao longo das últimas décadas. $\mathrm{O}$ autor apresenta dados que indicam um crescimento da preocupação das crianças com preço, sendo este item um fator preponderante em algumas escolhas de consumo. Em 1989, apenas 25\% das crianças pesquisadas por McNeal (1992) apresentavam uma preocupação com preço. Alguns anos mais tarde, esse valor subiu cerca de $50 \%$, atingindo a marca de $75 \%$ em 1995. Essa sensibilidade maior é encontrada em produtos que as crianças compram de forma regular, como refrigerantes e guloseimas. Produtos mais caros, como tênis ou videogames, não apresentam uma sensibilidade tão grande (MCNEAL, 1999).

Outros produtos, com valores ainda mais altos, estão fora da capacidade financeira da criança. Esses produtos são avaliados pelos pais, sendo eles os responsáveis por determinar se o preço está caro ou não (MCNEAL, 1999). Produtos que trazem benefícios para ambos, ou seja, que juntam diversão com entretenimento, são alvo de uma menor sensibilidade a preço, sobretudo por parte dos pais. $\mathrm{O}$ autor termina seu raciocínio colocando que produtos desejados pelas crianças, 
mas que não trazem apelo para os pais, serão vistos como muito caros e não serão comprados. Essa compra não se realizará mesmo que a criança tenha o dinheiro para tal, os pais serão responsáveis por vetar esse tipo de compra que é vista por eles como um desperdício.

Se até o começo da década de 80 apenas parte dos consumidores eram considerados caçadores de $\operatorname{preços}^{27}$, isso passou a ser diferente na década de 90, quando grande parte dos consumidores poderiam ser catalogados como tal (MCNEAL, 1999). No começo da década de 90, 75\% das pessoas apresentavam algum tipo de comportamento que poderia ser classificado como caçadores de preços, ou seja, pessoas que buscam ofertas, descontos e promoções. Para McNeal (1999), essa situação pode ser explicada pelos seguintes fatores:

- Ensinamento dos pais: por meio da observação as crianças aprendem com os pais que é necessário buscar produtos de marca, mas com preços baratos, possivelmente em varejistas de desconto, como por exemplo, K-Mart. Com o passar dos anos, a criança é cada vez mais influenciada pelos colegas e pelo grupo, dessa forma é possível que deixe de se preocupar tanto com os preços para poder participar de momentos de consumo com seus grupos de convívio, principalmente em lojas de conveniência, as quais notadamente apresentam preços mais altos.

- Influência dos pares: a influência dos pares se torna altamente significativa por volta dos 10 anos, tornando-se uma influência tão significativa quanto à influência dos pais. Os conhecimentos adquiridos junto aos pais não são simplesmente descartados, mas são comparados com os conhecimentos adquiridos junto aos pares. Cria-se assim uma situação de conflito para as crianças. Pesquisas realizadas indicam que o tópico preço não é tão incomum durantes momentos de consumo compartilhados por grupos de crianças.

- Comunicações de marketing relacionadas a preço: ao mesmo tempo em que os consumidores se tornaram mais sensíveis a preço, ocorreu uma investida das empresas no sentido de anunciar produtos e serviços que respondiam a essa

\footnotetext{
${ }^{27}$ Do inglês price shoppers - tradução do autor.
} 
crescente necessidade de seus clientes. Dessa forma, criou-se um circulo de aprendizado. Interessante notar, que parte dos varejistas busca esconder os preços praticados, fazendo com que a criança perceba a loja, como pode-se observar no trecho - "nossos preços são tão altos que estamos tentando esconde-los" (MCNEAL, 1999, p.135).

- Experiências da criança com preço: as experiências da criança, seja com pais, ou com colegas, trazem inúmeras informações que são responsáveis por incentivar o aprendizado da criança como consumidora. Esse aprendizado é incentivado por professores que utilizam preços como exemplos em sala de aula.

Com base nas colocações apresentadas, McNeal (1999) traz algumas sugestões para os profissionais de marketing interessados no mercado infantil e preocupados em como trabalhar a questão da precificação. Para o autor, os preços devem ser colocados de forma honesta. Enganar uma criança é algo fácil de se fazer, mas os resultados podem ser significativos, principalmente para empresas que estão buscando construir um relacionamento de longo prazo com seus consumidores. Sendo assim, as empresas deveriam colocar os preços dos produtos de forma bastante clara e objetiva, evitando-se termos mais adequados para adultos ou termos que possam ser vagos.

Os preços devem ser mostrados de forma franca, sincera, sem rodeios. Ainda, esse atributo deve ser comunicado de forma entusiástica, demonstrando que é baixo e que as crianças são desejadas como consumidores na loja em particular. Cupons são uma forma de trabalhar veementemente os preços, desde que isso seja feito de uma forma clara.

Percebeu-se, por meio dos trabalhos apresentados, que a criança passa por um processo de aprendizado no quesito preço. Ao longo do seu desenvolvimento, a criança adquire alguns conceitos sobre questões relacionadas à sensibilidade a preço e ao entendimento de como funciona o processo de troca (dinheiro por produtos que trazem benefícios). 


\subsubsection{O ponto de venda e o consumidor infantil}

McNeal (1992) coloca que os pais e os varejistas são as duas principais fontes de produtos e serviços que satisfazem as necessidades das crianças, porém nem todos os varejistas estão focados em compreender a criança e as limitações que ela possui para poder consumir. Por exemplo, Veloso e Hildebrand (2005) perceberam algumas limitações na distribuição dos produtos na gôndola do supermercado por eles pesquisado. Produtos fora do alcance da criança criaram situações onde a criança foi obrigada a pedir ajuda para poder comprar o que desejava. Situações como essas são nocivas para a percepção da criança com relação a quanto o varejista quer a criança no estabelecimento. Situações como essa já eram apresentadas por McNeal no ano de 1969, despertando o sentimento de que ainda existem varejistas que não perceberam a importância do consumidor infantil.

Tabela 4 - Tipos de varejistas classificados como orientados para a criança - 1984 versus 1991

\begin{tabular}{|l|c|c|c|c|c|}
\hline \multicolumn{1}{|c|}{ Tipo } & & \multicolumn{2}{c|}{ Responderam } & \multicolumn{2}{c|}{$\begin{array}{c}\text { São Orientados para a } \\
\text { criança }\end{array}$} \\
\hline Loja de departamentos & Contatados & No. & \% & \% - 1984 & 1991 \\
\hline Loja de variedades & 67 & 16 & 24 & 45 & 75 \\
\hline Lojas de desconto & 4 & 1 & 25 & 25 & 100 \\
\hline Supermercados & 15 & 4 & 27 & 80 & 75 \\
\hline Lojas de conveniência & 20 & 9 & 45 & 32 & 78 \\
\hline Restaurantes & 8 & 2 & 25 & 100 & 50 \\
\hline Drogarias & 21 & 8 & 38 & 39 & 75 \\
\hline Lojas de vestuário & 3 & 1 & 33 & 0 & 0 \\
\hline Hotéis & 15 & 8 & 53 & 22 & 50 \\
\hline Outros & 13 & 7 & 54 & 25 & 43 \\
\hline 1991 & 10 & 6 & 60 & 22 & 50 \\
\hline 1984 & 176 & 62 & 35 & & 68 \\
\hline
\end{tabular}

FONTE: MCNEAL; 1992, p.113.

Os varejistas deveriam estar mais preocupados com a participação da criança entre seus clientes, pelas razões a seguir (MCNEAL, 1992):

- A criança constitui um mercado tridimensional.

- As crianças economizam aproximadamente US\$2,5 bilhões por ano.

- As crianças compram uma gama relativamente grande de produtos e serviços, tendo um impacto maior em determinadas categorias como brinquedos e 
guloseimas e um impacto não tão grande, mas significativo, em categorias como roupas, vestuário, vídeo-games, eletrônicos em geral e entretenimento.

- As crianças fazem compras numa grande variedade de varejistas, tanto como consumidores solo, como acompanhantes dos pais. Por volta dos 10 anos, a criança já faz cerca de 250 visitas a varejistas por ano.

- Crianças fazem compras em conjunto com os pais, influenciando as decisões tomadas no ponto de venda e fazendo suas próprias compras.

- As crianças formam opiniões, percepções e preferências com relação a varejistas. As crianças começam suas idas aos varejistas com uma visão bastante positiva, pois para ela se tratam de grandes armazéns recheados com produtos que podem trazer satisfação. Com o passar dos anos, e com o crescimento do número de interações com os varejistas, a criança cria sua própria avaliação sobre o varejista em questão.

Partindo das colocações de McNeal (1992), é possível entender como um varejista mal preparado para receber as crianças pode minar suas chances de receber este consumidor, tanto no futuro mais próximo, como nos anos a seguir. Partindo do pressuposto de que os consumidores são roubados dos competidores, ou são criados a partir de uma gama de potenciais consumidores (neste caso as crianças), o autor analisa que as empresas deveriam despender esforços para tratar melhor este consumidor que é recém chegado ao mercado. Cria-se então um paradoxo - de um lado empresas lutando no mercado para atrair consumidores e de outro tratando mal jovens consumidores, que têm dinheiro no bolso, vontade de comprar e excitados pelo momento de consumo recém descoberto.

Com o intuito de direcionar o trabalho das empresas para serem mais adequadas ao consumidor infantil, McNeal (1992) oferece algumas sugestões:

- Treinar os funcionários para que eles estejam mais preparados para dar assistência para as crianças, que geralmente são novos consumidores e precisam de ajuda. 
- Prover mais educação para o consumidor, ou seja, desenvolver esforços direcionados para o treinamento dos consumidores no que se refere às habilidades necessárias para o consumo de determinado produto em determinada loja.

- Instituir práticas mais éticas, pois servir às crianças não é o mesmo que servir os adultos. Enquanto os adultos já desenvolveram uma série de valores, a criança ainda está no processo de desenvolvimento dos seus valores. Por isso algumas precauções devem ser tomadas para não expor as crianças a produtos ou serviços considerados inadequados.

McNeal (1999) realizou uma pesquisa com crianças entre 6 ou 7 e 11 ou 12, buscando identificar quais as lojas onde uma criança gastaria 100 dólares. A grande maioria das crianças gastaria esse dinheiro em Hipermercados (48\%), em segundo lugar aparecem os shopping centers (24\%), em terceiro lugar as lojas de especialidade (14\%), empatados em quarto lugar aparecem as lojas de departamentos e os supermercados (7\%). O Quadro 20 traz informações importantes para o entendimento da relação da criança com as lojas durante o seu processo de desenvolvimento como consumidora.

\begin{tabular}{|l|l|l|}
\multicolumn{2}{|c|}{ Quadro 20 - Lojas favoritas das crianças } \\
\hline Crianças jovens (6 ou 7 anos) & $\begin{array}{l}\text { Crianças com idade média (8 ou 9 } \\
\text { anos) }\end{array}$ & Pré-adolescente (10 a 12 anos) \\
\hline Conveniência & Desconto de Massa & Desconto de Massa \\
\hline Supermercado & Supermercado & Loja de Especialidade \\
\hline Desconto de Massa & Loja de Especialidade & Supermercado \\
\hline
\end{tabular}

A criança realiza suas primeiras compras independentes em lojas de conveniência (MCNEAL, 1992; 1999; 2006). Essa primazia nas primeiras experiências de consumo podem ser explicadas pela proximidade da loja, a disponibilidade de produtos voltados para a criança e o pequeno tamanho dessas lojas que as torna mais fáceis de serem manejadas pelas crianças (MCNEAL, 1999). A falta de atenção dos gerentes e funcionários das lojas de conveniência faz com que essa relação não seja duradoura (MCNEAL, 1999). Num segundo momento, as crianças passam a preferir as lojas de desconto de massa, principalmente pelo número de brinquedos disponíveis, visto que elas se encontram numa fase em que o brincar assume grande importância. 
McNeal (1999) analisou uma série de estudos conduzidos com crianças para identificar quais seriam os fatores que tornariam uma determinada loja mais atrativa para as crianças, conforme Ilustração 20 .

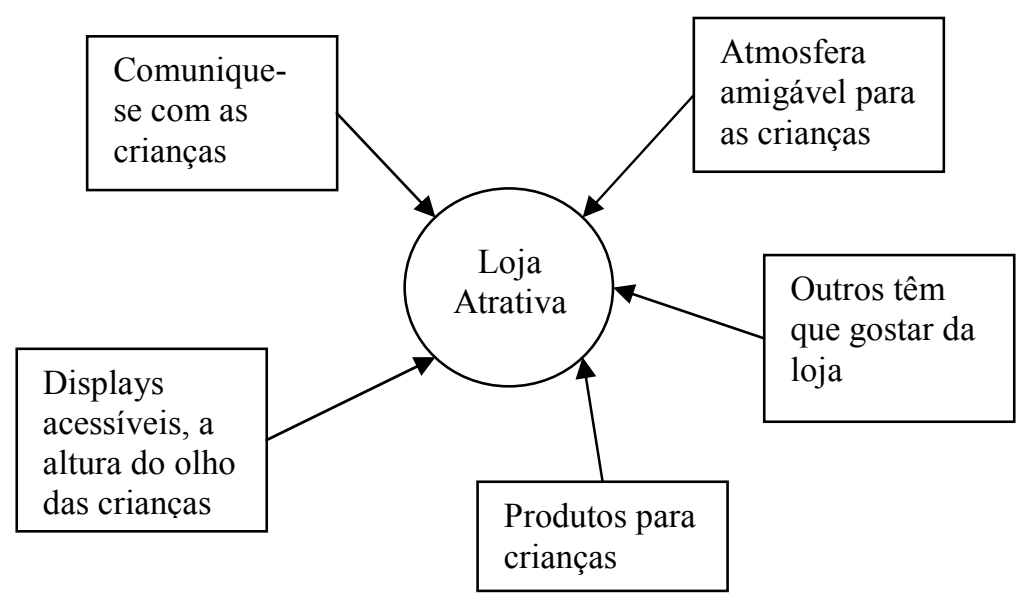

Ilustração 20 - O que faz uma loja ser a favorita das crianças? FONTE: MCNEAL; 1999, p.125.

McNeal (1999) fundamenta suas colocações a respeito da atratividade de uma determinada loja nos seguintes fatores: é necessário que todo o desenvolvimento da loja seja pensando para criar uma loja fisicamente pensada para as crianças (todos os aspectos do consumo relacionados à criança são desenvolvidos da forma mais adequada, como por exemplo, a altura dos displays, gôndolas etc.); que o estabelecimento tenha seu sortimento adequado ao público infantil (marcas e produtos); e que notadamente aceite e deseje a presença de crianças no ambiente (funcionários e ambiente da loja devem transmitir essa sensação). Além disso, a loja deve ser bem vista e freqüentada por outros grupos, como os pais ou crianças mais velhas.

Pesquisadores brasileiros fazem coro às colocações de $\mathrm{McNeal}$ em pesquisas empíricas desenvolvidas aqui no país. Partindo das pesquisas de McNeal (1992; 1999; 2006), Veloso e Hildebrand (2006) analisaram o comportamento da criança no ambiente varejista e fizeram algumas sugestões concernindo essa questão. Primeiramente, destacam os autores que as mudanças ocorridas nos primeiros anos de vida de um indivíduo devem ser percebidas pelos varejistas, tendo essa ação impacto direto na satisfação deste consumidor infantil. 
Quanto ao layout do ponto de venda mais especificamente, considerado um dos maiores empecilhos ao consumo entre o público infantil, sugerem Veloso e Hildebrand (2006) que seja criado um ambiente restrito e supervisionado dentro da loja, onde a criança pudesse escolher produtos, brincar e até comprá-los.

Este tópico permitiu compreender melhor a relação da criança com o ponto de venda. A sugestão mais importante que se extrai dos textos apresentados foca no direcionamento do varejista para o público infantil, deixando claro que este público é bem vindo no seu estabelecimento, tanto por meio do comportamento dos funcionários, como pelo ambiente da loja.

\subsubsection{Estratégias de comunicação com o consumidor infantil}

O primeiro passo para desenvolver uma estratégia adequada de comunicação é definir onde se encontra a audiência-alvo. De acordo com Acuff e Reiher (1997), as crianças podem ser encontradas em 5 locais principais:

1. Em casa: as crianças que se encontram no seu próprio domicílio podem receber estímulos por meio de propagandas transmitidas (televisão, rádio), programas de computadores e internet, publicações voltadas para as crianças ou voltadas para os adultos. Os infantes também podem ser influenciados por embalagens que a mãe leva para casa.

2. Em lojas: as crianças sempre estão nas lojas, sejam acompanhadas pelos pais ou sozinhas. As embalagens são um dos apelos mais importantes nesse ambiente, a seguir aparecem os displays, vídeos e áudio.

3. Na comunidade: as crianças estão espalhadas pela cidade, em locais como o cinema, restaurantes fast-food e quadras desportivas. Aqui as crianças podem ser atingidas por meio de embalagens, promoções, clipes e trailers de filmes, displays no cinema, design da loja, pôsteres de esportes e publicações. 
4. Nas escolas: antes de irem para a escola primária, as crianças já estão em escolas, sejam elas pré-primarias ou creches. Nesses locais, elas são atingidas por publicações e televisão. A partir da escola primária, a criança pode ser alvo de publicações, promoções, promoções casadas, distribuição de brindes relacionados a produtos e programas voltados à criança.

5. Em carros: as crianças passam considerável parte do dia no automóvel da família. Nesse ambiente, elas podem ser atingidas pelas transmissões de rádio.

Acuff e Reiher (1997) não abordam a presença da criança em meios de transporte coletivos, fazendo com que a análise dos autores perca em riqueza. $\mathrm{O}$ impacto dessa falha talvez seja menor em países como os Estados Unidos, onde grande parte da população possui carro, mas em países em desenvolvimento, como o Brasil, não é possível tratar esse tema sem abordar a questão do impacto da mídia disponível no transporte coletivo. Infelizmente não existem trabalhos na literatura brasileira de marketing que abordam essa questão.

A seguir é apresentado o Quadro 21, desenvolvido de acordo com as sugestões a análises feitas por Acuff e Reiher (1997) sobre as diferentes faixas etárias e as mídias mais apropriadas para o desenvolvimento atual da criança. O quadro possibilita uma visão bastante ampla das possibilidades que se apresentam em termos de comunicação ao longo dos 12 primeiros anos de vida de uma criança. 
Quadro 21 - Marketing para os sucessivos segmentos de idade por meio de várias mídias

\begin{tabular}{|c|c|c|c|}
\hline Mídia & 0 a 2 anos & 3 a 7 anos & 8 a 12 anos \\
\hline $\begin{array}{l}\text { Programação } \\
\text { televisiva e } \\
\text { propaganda }\end{array}$ & $\begin{array}{l}\text { Apesar de estarem expostos a } \\
\text { mídia televisiva e a propaganda } \\
\text { desde os primeiro meses, é } \\
\text { somente depois dos } 2 \text { anos que } \\
\text { ela terá consciência dos } \\
\text { personagens e dos produtos } \\
\text { presentes durante r a } \\
\text { programação e durante os } \\
\text { intervalos. }\end{array}$ & $\begin{array}{l}\text { Crianças desta idade ainda não } \\
\text { possuem as habilidades necessárias } \\
\text { para avaliar criticamente os objetivos } \\
\text { e os apelos da propaganda televisiva, } \\
\text { tornando-se então alvos fáceis para a } \\
\text { propaganda e para as empresas. } \\
\text { Obviamente restrições éticas se } \\
\text { aplicam em razão dessa mesma } \\
\text { característica. As propagandas devem } \\
\text { ser diretas, concretas e altamente } \\
\text { visuais. Situações abstratas ou que } \\
\text { exigem algum tipo de } \\
\text { complementação devem ser evitadas. }\end{array}$ & $\begin{array}{l}\text { Crianças desta faixa etária assistem cerca de } 30 \text { horas de televisão por } \\
\text { semana, ou seja, estão expostos a um grande número de programas e } \\
\text { propagandas. A criança, nesta faixa etária, consegue analisar melhor o } \\
\text { que está sendo dito na propaganda e também consegue pesar as } \\
\text { promessas feitas. Enquanto as crianças da faixa etária anterior são } \\
\text { voltadas para o mundo da fantasia, as crianças desta faixa etária estão } \\
\text { voltadas para o mundo real. As crianças entre } 8 \text { e } 12 \text { anos apresentam a } \\
\text { necessidade de se distanciar das crianças com menos de } 7 \text { anos, ou seja, } \\
\text { não querem mais os mesmos produtos, não assistem mais os mesmos } \\
\text { programas. A criança acima de } 8 \text { anos quer parecer mais velha, por isso } \\
\text { quando forem feitas propagandas televisivas com crianças de verdade } \\
\text { elas devem ter uma idade ligeiramente superior àquela do público alvo. }\end{array}$ \\
\hline Embalagem & $\begin{array}{l}\text { Da mesma forma, a criança só } \\
\text { começara a responder ao apelo } \\
\text { das embalagens a partir dos } 2 \\
\text { ou } 3 \text { anos. Embalagens } \\
\text { coloridas e destacadas na } \\
\text { prateleira chamam a atenção da } \\
\text { criança, fazendo com que ela } \\
\text { solicite o produto aos pais. }\end{array}$ & $\begin{array}{l}\text { A embalagem tem um papel muito } \\
\text { importante durante esta etapa. A } \\
\text { empresa deve trabalhar cores fortes e } \\
\text { marcantes, personagens que sejam } \\
\text { fortes, engraçados, populares e } \\
\text { atrativos, os quais devem ser } \\
\text { apresentados em poses e situações } \\
\text { engraçadas. }\end{array}$ & $\begin{array}{l}\text { Geralmente as empresas não diferenciam entre crianças de } 3 \text { a } 7 \text { anos e } \\
\text { de } 8 \text { a } 12 \text { anos quando desenvolvem a embalagem. Caso assim o } \\
\text { fizessem elas perceberiam as grandes diferenças que existem. De forma } \\
\text { geral a embalagem para este grupo deve ser mais trabalhada, seja com } \\
\text { cores diferenciadas, seja com design diferenciado, seja com } \\
\text { personagens mais arrojados (esportistas, músicos, desenhos animados } \\
\text { como os Simpsons ou South Park). }\end{array}$ \\
\hline Promoções & $\begin{array}{l}\text { Muitas das promoções são } \\
\text { sofisticadas demais para } \\
\text { crianças abaixo de dois anos, } \\
\text { mas promoções bem } \\
\text { desenhadas, com apelos fortes, } \\
\text { visuais e simples podem ter } \\
\text { sucesso. }\end{array}$ & $\begin{array}{l}\text { Crianças desta idade têm uma grande } \\
\text { predisposição a promoções, seja um } \\
\text { brinde na refeição do fast-food ou um } \\
\text { brinde distribuído gratuitamente por } \\
\text { uma determinada loja. As } \\
\text { considerações feitas anteriormente } \\
\text { sobre o entendimento da propaganda } \\
\text { valem para as promoções também. }\end{array}$ & $\begin{array}{l}\text { Essa criança está passando por um momento onde grande parte de suas } \\
\text { preocupações é voltada para a inserção em determinados grupos sociais. } \\
\text { Promoções que incentivem a relação da criança com outros, ou que } \\
\text { possibilitem sua expressão por meio de correio, telefone e } \\
\text { computadores são bem vindas. Nessa época a criança também começa a } \\
\text { participar mais ativamente de clubes e organizações. }\end{array}$ \\
\hline $\begin{array}{l}\text { Revistas } \\
\text { livros }\end{array}$ & $\begin{array}{l}\text { Até os dois anos a criança tem } \\
\text { quase nenhum contato direto } \\
\text { com revistas, mas têm um } \\
\text { contato bastante considerável } \\
\text { com livros que são lidos por } \\
\text { algum familiar, como os pais } \\
\text { ou os avós. }\end{array}$ & $\begin{array}{l}\text { Durante esta etapa a criança começa a } \\
\text { ler revistas direcionadas } \\
\text { especificamente para eles. }\end{array}$ & $\begin{array}{l}\text { Revistas direcionadas para as novas atividades que a criança está } \\
\text { realizando terão chances de sucesso. A criança quer fazer parte de um } \\
\text { grupo, conhecer profundamente a atividade em que este grupo está } \\
\text { envolvido é um caminho para a aceitação. As crianças dessa faixa etária } \\
\text { costumam ler uma revista da primeira a última página, prestando } \\
\text { atenção mais profunda e continuada em relação a outros grupos. }\end{array}$ \\
\hline Jornal & Praticamente nenhum impacto. & Pequeno envolvimento, & A leitura de jornais se torna um pouco mais efetiva, mas ainda restrita \\
\hline
\end{tabular}




\begin{tabular}{|l|l|l|l|}
\hline & & $\begin{array}{l}\text { principalmente com a parte das tiras } \\
\text { cômicas. }\end{array}$ & $\begin{array}{l}\text { as secções de interesse da criança, como os quadrinhos. Jornais com } \\
\text { uma parte destinada especificamente às crianças terão uma gama de } \\
\text { leitores maior. }\end{array}$ \\
\hline Radio & $\begin{array}{l}\text { Pequeno impacto, pois requere } \\
\text { uma habilidade que ainda não } \\
\text { foi desenvolvida pelas crianças } \\
\text { aos 2 anos de idade. }\end{array}$ & $\begin{array}{l}\text { A rádio torna-se mais presente de } \\
\text { acordo com a idade. Quanto mais } \\
\text { próxima dos 7 anos, maior será sua } \\
\text { vontade de escutar determinadas } \\
\text { rádios que apresentam uma } \\
\text { programação mais direcionada para a } \\
\text { criança. }\end{array}$ & $\begin{array}{l}\text { Cerca de 90\% das crianças entre } 12 \text { anos escutam entre 1 e 16 horas } \\
\text { semanais de rádio. Apenas ma pequena parte destes ouvintes estará } \\
\text { ligado em rádios direcionadas às crianças, a grande maioria dos } \\
\text { ouvintes estará escutando rádios voltadas para os adultos. }\end{array}$ \\
\hline $\begin{array}{l}\text { Computador } \\
\text { es }\end{array}$ & $\begin{array}{l}\text { Somente crianças acima de 3 } \\
\text { anos conseguem compreender } \\
\text { os programas mais simples de } \\
\text { computação. }\end{array}$ & $\begin{array}{l}\text { Programas que utilizam personagens } \\
\text { de filmes ou séries têm grandes } \\
\text { chances de se tornarem alvo de } \\
\text { desejo, permitindo que a empresa } \\
\text { faça uma venda cruza com outras } \\
\text { çategorias de produtos que também } \\
\text { utilizam os personagens. }\end{array}$ & $\begin{array}{l}\text { Programas que utilizam personagens animados, de empresas como } \\
\text { Disney ou Warner, podem trabalhar duas vantagens: educação e } \\
\text { promoçónen encartadas nos mais diversos tipos de programas. }\end{array}$ \\
\hline Internet & $\begin{array}{l}\text { Praticamente nenhum } \\
\text { envolvimento ou contato. }\end{array}$ & $\begin{array}{l}\text { Muitas crianças desta faixa etária } \\
\text { estão começando a entrar em contato } \\
\text { com a Internet, mas esse uso ainda é } \\
\text { incipiente. }\end{array}$ & $\begin{array}{l}\text { O número de crianças desta faixa etária que estão acessando a Internet } \\
\text { cresce a cada dia. A tendência é que esse acesso cresce, fazendo com } \\
\text { que a Internet torne-se um canal de comunicação muito importante. }\end{array}$ \\
\hline
\end{tabular}

FONTE: ACUFF e REIHER; 1997, p.179-187. 
Para complementar as informações apresentadas no Quadro 21, apresenta-se a Tabela 5. Nesta tabela são apresentados os dados referentes a disponibilidade de mídias no quarto de crianças norte-americanas. Apesar de este ser um dado não diretamente relacionado a realidade das empresas nacionais, não cabe deixar de analisar quais são os meios disponíveis para que empresas americanas se comuniquem com seus consumidores.

Tabela 5 - Disponibilidade dos diversos tipos de mídia no quarto das crianças norte americanas

\begin{tabular}{|l|c|c|c|}
\hline & \multicolumn{3}{|c|}{ IDADE } \\
\hline Mídia & $\mathbf{2 - 4}$ anos & $\mathbf{5 - 7}$ anos & $\mathbf{8 - 1 3}$ anos \\
\hline Televisão & $26 \%$ & $39 \%$ & $65 \%$ \\
\hline Vídeo-Cassete & $14 \%$ & $18 \%$ & $34 \%$ \\
\hline Rádio & $32 \%$ & $53 \%$ & $81 \%$ \\
\hline Toca-Fita & $32 \%$ & $41 \%$ & $74 \%$ \\
\hline CD Player & $9 \%$ & $18 \%$ & $64 \%$ \\
\hline Vídeo Game & $7 \%$ & $18 \%$ & $47 \%$ \\
\hline Computador & $4 \%$ & $9 \%$ & $23 \%$ \\
\hline TV a Cabo ou Satélite & $10 \%$ & $18 \%$ & $28 \%$ \\
\hline Canais Premiun na TV Paga & $4 \%$ & $5 \%$ & $15 \%$ \\
\hline Internet & $1 \%$ & $2 \%$ & $9 \%$ \\
\hline Drive CD-ROM & $1 \%$ & $5 \%$ & $14 \%$ \\
\hline
\end{tabular}

FONTE: ROBERTS et al.; 1999, p. 13.

A idéia de analisar as mídias presentes no quarto da criança é importante, pois existe aqui um determinado nível de liberdade para a criança escolher quanto tempo e qual nível de atenção dedicará para cada uma das mídias. Diferente de uma televisão na sala de estar, a televisão no quarto da criança estará sob seu total controle. Apesar de não existirem dados semelhantes para a realidade nacional, cabe salientar a valia de tais dados.

Dentre os diversos tipos de mídia que estão presentes no quarto das crianças, destaca-se a televisão (com ou sem a presença de canais pagos) como um dos meios que mais permite a comunicação entre as empresas e as crianças (ROBERTS et al., 2005). Por meio da televisão e dos diferentes tipos de canais, as empresas conseguem transmitir suas mensagens por meio das propagandas, inserções comerciais e colocação de produtos ${ }^{28}$ em séries, filmes etc.

A Internet ainda não tem a mesma representativididade no quarto das crianças, conforme a Tabela 5, mas os dados sinalizam para o crescimento dessa presença nos próximos anos. Com

\footnotetext{
${ }^{28}$ Do conceito Product Placement, aqui traduzido por colocação de produto, tradução do autor.
} 
esse crescimento surgirá um canal de comunicação direto com a criança. Apesar disso, cabe colocar que existe uma corrente que percebe as ações diretas para a criança como sendo uma questão muito sensível, que merece uma atenção especial da empresa (KOUZELEAS, 2005).

Uma questão muito importante que se apresenta para o profissional de marketing ao idealizar uma comunicação é a quem direcionar a propaganda. A empresa deve escolher entre direcionar a propaganda para os pais da criança, ou para a própria criança (SIEGEL et al., 2001). Essa dúvida aparece porque a mãe, ou o pai, será o responsável pela compra e pela escolha do produto em grande parte das ocasiões. Os autores analisam essa questão e com base em resultados empíricos de pesquisas, que apontam que, dentre as três opções (1 - propaganda apenas para a criança; 2 propagandas para as crianças e para os pais e 3 - propaganda para os pais), a que apresenta os melhores resultados é a propaganda ${ }^{29}$ direcionada apenas para as crianças. Outra vantagem de anunciar apenas para crianças reside no preço da propaganda, ou seja, é mais barato colocar uma propaganda no período matinal do que no horário nobre noturno da televisão (SIEGEL et al., 2001).

Dotson e Hyatt (2000) buscaram avaliar o conhecimento das crianças com relação às marcas e a seus respectivos slogans apresentados em comerciais televisivos. Para essa pesquisa foram utilizadas marcas e slogans de categorias de produto voltadas às crianças (fast-food, salgadinhos e doces) e aos adultos (produtos de limpeza, desodorante e cerveja). Os resultados indicam que crianças a partir dos 9 anos já possuem um conhecimento similar ao conhecimento dos seus pais, até mesmo em relação a comerciais de produtos destinados ao público adulto. Destarte, pode-se compreender que a partir de certa idade a criança passa a reconhecer e a guardar na memória os mais diferentes slogans e marcas. Além disso, ela passa a ser exposta a marcas destinadas a outros grupos de consumidores, incluindo ai produtos que são de alguma forma coibidos para elas, como a cerveja.

Se a empresa decidir anunciar para ambos os grupos, ela pode escolher entre apresentar uma mesma propaganda ou realizar duas propagandas diferentes (SIEGEL et al., 2001). Caso a empresa decida colocar no ar apenas uma propaganda, deve existir uma preocupação e uma

\footnotetext{
${ }^{29} \mathrm{O}$ estudo, denominado The Nag Study, avaliou o impacto da propaganda televisiva e da propaganda impressa.
} 
profunda análise dos resultados obtidos junto à audiência-alvo, considerando que pais e crianças devem assistir à mesma propaganda, mas compreender as mensagens de forma diferente.

Dentro de outro escopo temático, McNeal (1999) destaca a visão negativa que parte do público tem em relação à propaganda. De acordo com o autor, isso acontece porque algumas empresas desenvolvem propagandas que denigrem a imagem da categoria como um todo.

\begin{tabular}{|c|c|c|c|c|}
\hline $\begin{array}{l}\text { Propagandas } \\
\text { destinadas às } \\
\text { crianças } \\
\text { contendo } \\
\text { mensagens não } \\
\text { adequadas }\end{array}$ & $\begin{array}{l}\text { Descrença } \\
\text { naquela } \\
\text { propaganda } \\
\text { e naquele } \\
\text { anunciante }\end{array}$ & $\begin{array}{l}\text { Descrença } \\
\text { na } \\
\text { propaganda } \\
\text { de forma } \\
\text { geral }\end{array}$ & $\begin{array}{l}\text { Defende-se } \\
\text { e evita a } \\
\text { propaganda } \\
\text { destinada às } \\
\text { crianças }\end{array}$ & $\begin{array}{l}\text { Perda da } \\
\text { efetividade } \\
\text { da } \\
\text { propaganda } \\
\text { para } \\
\text { crianças }\end{array}$ \\
\hline
\end{tabular}

Ilustração 21 - Propagandas mal feitas produzem maus resultados para os profissionais da propaganda e para consumidores

FONTE: MCNEAL; 1999, p.146.

A partir da Ilustração 21 é possível compreender melhor como os próprios responsáveis pela propaganda geram uma visão negativa por parte dos pais das crianças. $\mathrm{O}$ autor segue sua análise e apresenta algumas sugestões sobre como a empresa pode desenvolver uma propaganda sem criar uma mensagem enganadora:

- Venda menos: prometa menos do que pretende oferecer, dê desconto de forma inadvertida ou dê brindes surpresa. De forma geral o autor sugere que a empresa venda por menos, mas sem anunciar isso, dessa forma o consumidor infantil estará sempre sendo surpreendido positivamente pela oferta da empresa.

- Prometa menos: a empresa não precisa fazer propaganda que tenha a voz mais alta, isso pode passar a impressão de que a empresa está desesperada em fazer sua mensagem ser ouvida. Se a sua empresa possui um produto superior isso deve bastar para que sua propaganda seja ouvida.

- Promocione menos: os pais estão cansados de propagadas que utilizam apenas o apelo de venda, talvez porque grande parte dos comerciais destinados às crianças estão focados em 
promoções, concursos, junções de marcas (Star Wars e McDonalds). A sugestão do autor é utilizar uma forma mais comedida deste tipo de estratégia.

- Ressalte o conceito de família: a família é um dos grupos sociais mais importantes, o qual vem ganhando importância maior nos últimos anos. Dessa forma, o autor sugere que a empresa utiliza sempre que possível a família como pano de fundo para os comerciais, com uma conotação positiva é claro.

- Não seja desonesto: é fácil utilizar um ângulo de câmera para fazer o carrinho de brinquedo parecer maior do que é realmente, é fácil dizer que não existem obrigações ao assinar uma revista e depois colocar essas obrigações de forma disfarçada.

Antes de finalizar este tópico sobre a comunicação com o publico infantil, cabe trazer informações sobre o debate acerca do impacto da propaganda sobre as crianças, debate este que se fundamenta nas vulnerabilidades próprias desse público (MOORE, 2004; MOSES e BALDWIN, 2005). Essa vulnerabilidade decorre da abertura que a criança dá para novas informações (MOSES e BALDWIN, 2005). Essa condição do infante faz com que se torne necessário questionar se é apropriado expô-lo a comerciais sofisticados e em alguns casos enganadores (MOSES e BALDWIN, 2005).

Essas preocupações datam do início da década de 70, quando foram estruturadas as primeiras iniciativas no sentido de estudar o impacto das propagandas e controlar a quantidade de apelos que atingiam as crianças (JOHN, 1999). Essas iniciativas tomaram lugar, tanto nos Estados Unidos, como na Europa, onde o desenvolvimento tecnológico e as exigências propostas pela União Européia, no sentido de harmonizar a legislação, geraram um aumento das investidas nesta área de pesquisa durante os últimos 10 anos (OATES et al., 2003). John (1999) destaca alguns dos pontos mais analisados e estudados pelos estudiosos do impacto da mídia televisiva sobre a criança:

- Capacidade de distinguir entre comerciais e a programação normal (filmes, séries, etc).

- Capacidade da criança em entender as intenções de um comercial. 
Antes de ter a capacidade de entender um comercial, a criança necessita saber distingui-lo da programação normal da televisão (MOSES e BALDWIN, 2005). Essa diferenciação não pode ser apenas baseada em fatores superficiais, que podem não ter nada a ver com as diferenças críticas entre um comercial e a programação.

De acordo com John (1999), é por volta dos 5 anos que a criança começa a perceber a diferença entre comerciais e a programação televisiva. Antes da pesquisadora, Brée (1995) realizou extensa revisão bibliográfica e questiona os resultados encontrados pela literatura. De acordo com o autor, existem trabalhos que afirmam que crianças de 4 ou 5 anos já reconhecem essas diferenças, assim como existem trabalhos colocam esse evolução durante os 6 ou 7 anos. Outros trabalhos analisados pelo autor consideram que parte das crianças somente adquire a capacidade de diferenciar entre um comercial e a programação normal da televisão por volta dos 10 ou 11 anos.

Essa profusão de resultados é oriunda dos diferentes enfoques metodológicos utilizados (BRÉE, 1995). A questão metodológica aqui colocada surge nos instrumentos e estratégias de coleta dos dados. Enquanto alguns trabalhos utilizam medidas verbais outros utilizam medidas não verbais. Os métodos verbais podem produzir resultados enganadores na opinião de Moses e Baldwin (2005), pois as crianças ainda não estão suficientemente desenvolvidas para realmente compreender as questões colocadas pelos pesquisadores (DONOHUE et al., 1980).

[...] nós acreditamos que os pesquisadores não podem realisticamente determinar como a televisão afeta as crianças com uma mínima acuracidade enquanto eles utilizarem as habilidades verbais como ferramenta metodológica. (DONOHUE et al., 1980, p. 56).

Essas considerações direcionaram alguns autores a realizarem estudos exclusivamente qualitativos, com o apoio da técnica de grupo de foco (LAWLOR e PROTHERO, 2003; DONOHUE et al., 1980; OATES et al., 2003) ou entrevistas em profundidade (CHAN, 2000) para coletar dados relacionados ao tema.

Em muitos casos, principalmente para crianças com uma idade inferior, o reconhecimento de que aquilo que está sendo transmitido é um comercial, ainda não se relaciona com uma perfeita percepção do significado de um comercial (BRÉE, 1995). Essas crianças parecem reconhecer a 
diferença com base em fatores como a duração (comerciais são mais curtos) e o nível de entretenimento oferecido (comerciais são mais divertidos) (BRÉE, 1995; MOSES e BALDWIN, 2005).

Dentro desta mesma linha, Martin (1997) realiza uma meta-análise e conclui que diferenças nas metodologias utilizadas explicam a variância nos resultados que buscam entender a relação entre idade e nível de entendimento do objetivo do comercial. Os resultados de Martin (1997) são corroborados pelas considerações de John (1999), ao destacar que questionamentos podem ser levantados quanto à capacidade da criança em reconhecer o objetivo do comercial, ou conforme esclarecem Moses e Balwin (2005), ao defenderem que convencer o receptor da mensagem a mudar de atitude ou comprar produtos ou serviços. Quando a criança ainda não reconhece esse objetivo, ela ainda não pode criticamente avaliar determinado comercial.

A diferenciação entre um comercial e a programação normal da televisão se torna ainda mais confusa quando o comercial é desenvolvido utilizando insumos ou formatos oriundos da programação normal (BRÉE, 1995). Dessa forma, quando são utilizados personagens de desenhos, filmes ou atores do cinema ou televisão, a criança se confunde e não consegue identificar perfeitamente as diferenças. Essas colocações permitem entender as considerações de Khatibi et al. (2004), os quais indicam que as empresas estão desenvolvendo comerciais direcionados a crianças de todas as idades por muitos anos. Esses comerciais têm sido alvo de inúmeras críticas, pois são direcionados para um público que não é maturo o bastante para avaliar de forma crítica as mensagem recebidas. Essa situação é mais problemática quando a criança não reconhece que se trata de um comercial, mas não deixa de ser uma questão merecedora de atenção mesmo quando a criança consegue reconhecer essa diferença.

Apesar da pesquisa realizada por Khatibi et al. (2004) demonstrar que grande parte das crianças entre 5 e 8 anos reconhece um comercial, apenas 31,1\% das crianças pesquisadas reconhecem que um comercial tenta vender coisas, tenta fazer dinheiro ou mostra coisas que podem ser compradas. Khatibi et al. (2004) finalizam seu trabalho apresentando como limitação de seu estudo a raça das crianças pesquisadas (principalmente indianas e chinesas). Essas considerações podem ser relacionadas com a avaliação de Brée (1995) sobre os diversos resultados encontrados 
na literatura em relação às questões em discussão neste momento. Além de problemas de enfoque metodológico (MARTIN, 1997; BRÉE, 1995), problemas relacionados a diferenças culturais podem ser responsáveis pelos resultados inconclusivos nos estudos que tentaram identificar a capacidade da criança em distinguir entre um comercial e a programação normal da televisão.

Moore (2004) expande as questões sobre a capacidade da criança em distinguir entre comerciais e a programação televisiva para as novas iniciativas sendo desenvolvidas pelas empresas. Entre essas novas iniciativas, a autora destaca o desenvolvimento de comerciais que parecem entretenimento, mas que na realidade têm como objetivo transmitir os valores da marca e criar uma percepção positiva das marcas da empresa. A autora também destaca o desenvolvimento de sites, com jogos e brincadeiras, que buscam oferecer momentos de entretenimento às crianças e ao mesmo tempo trabalhar as marcas e produtos da empresa.

Outras iniciativas nesta mesma linha incluem o lançamento de revistas destinadas ao público infantil e que estão recheadas de brindes e jogos patrocinados por marcas e produtos, assim como a colocação de produtos em programas variados (filmes, séries etc). Moses e Baldwin (2005) avaliam as diferentes técnicas de marketing (informerciais, comerciais pela internet e merchandising), colocando que essas iniciativas são ainda mais sofisticadas no sentido de persuadir os receptores das mensagens, portanto, merecem estudos mais aprofundados.

A colocação de produtos em programas que são vistos pelas crianças parece ter um impacto bastante significativo no comportamento das crianças. Auty e Lewis (2004) conduziram um experimento com crianças entre 6 e 12 anos e detectaram que a colocação de produto pode impactar nas escolhas das crianças de forma significativa. Auty e Lewis (2004) selecionaram dois trechos do filme Esqueceram de $\mathrm{Mim}^{30}$. Num desses trechos do filme, são feitas menções à Pepsi e mostra-se uma lata do refrigerante. $\mathrm{O}$ outro trecho do filme não apresentava nenhuma marca de refrigerante. Após a exibição dos filmes, as crianças tinham a chance de escolher um refrigerante para tomar, sendo as opções disponíveis Coca-Cola e Pepsi. Os resultados foram: 58\% Coca-Cola e $42 \%$ Pepsi (grupo de controle); $38 \%$ Coca-Cola e $62 \%$ Pepsi (grupo que viu filme onde

\footnotetext{
${ }^{30}$ Filme intitulado Home Alone, dirigido por Chris Columbus em 1990.
} 
aparecia a Pepsi). Os números gerais da Grã-Bretanha, onde foi realizado o estudo, tem uma distribuição de $75 \%$ das vendas para a Coca-Cola e 25\% para a Pepsi.

Conclusões apresentadas por Ward e Wackman (1974) indicam que as crianças que estão atravessando a fase operacional-concreta do desenvolvimento cognitivo - 7 aos 11 anos, (KAIL, 2004) - apresentam um melhor entendimento das intenções de um comercial e são mais céticas com relação aos apelos da propaganda. De acordo com os autores, essa percepção surge nas crianças com base em experiências negativas com comerciais que prometem demais ou produtos que entregam de menos, corroborando os resultados de Oates et al., (2003). Moschis (1981) apresenta considerações fundamentadas em pesquisa empírica e clama mudanças nas políticas públicas que tentam proteger a criança do impacto da mídia. Segundo o autor, as políticas da época não eram adequadas, pois focavam crianças abaixo dos 12 anos, sendo que sua pesquisa indica que crianças no começo da adolescência ainda estão em estágio de desenvolvimento de suas capacidades cognitivas, as quais permitem entender melhor o significado de um comercial.

O Quadro 22, produzido por Oates et al. (2003, p. 67), traz os resultados de pesquisa qualitativa conduzida por meio de grupos de foco com crianças britânicas entre 6 e 10 anos.

\section{Quadro 22 - Entendimento da natureza da propaganda}

\begin{tabular}{|l|l|}
\hline Idade & \multicolumn{1}{c|}{ Nível de entendimento } \\
\hline 8 anos & $\begin{array}{l}\text { Os comerciais são feitos para que os telespectadores e os atores possam descansar. } \\
\text { Os comerciais contam o que vai passar na televisão e o que está presente nas lojas. } \\
\text { Os comerciais são apreciados, menos aqueles direcionados para bebês ou crianças mais novas. } \\
\text { Comercias são percebidos como acontecendo em tempo real. }\end{array}$ \\
\hline $\begin{array}{l}\text { Os comerciais são um descanso e para informar, mas fatores econômicos começam a aparecer. } \\
\text { Pouca percepção da natureza persuasiva do comercial. } \\
\text { Experiência pessoal começa a influenciar as opiniões sobre os comerciais, mas apenas em } \\
\text { situações especificas. } \\
\text { Os comercias são percebidos como acontecendo em tempo real. }\end{array}$ \\
\hline 10 anos & $\begin{array}{l}\text { Os comerciais ainda são vistos como uma razão para descansar e para informar, mas a } \\
\text { persuasão surge como base para explicar situações pessoais de desilusão. } \\
\text { O conceito de que os comerciais são previamente gravados para depois serem televisionados } \\
\text { surge mais frequentemente. }\end{array}$ \\
\hline
\end{tabular}

FONTE: OATES et al.; 2003, p.67.

Os achados apresentados por Oates et al. (2003) são similares aos encontrados por Chan (2000), que pesquisou crianças de Hong Kong. A autora considera que a classificação de desenvolvimento criada por Piaget é bastante adequada para a questão da relação da criança com a propaganda. Os resultados de Chan (2000) trazem importantes reflexões sobre o impacto da 
cultura sobre o processo de socialização. As crianças de Hong Kong e do Reino Unido apresentam resultados similares no que se refere ao entendimento da natureza da propaganda, isso pode ter ocorrido em função de culturas similares, ou em razão de um impacto pequeno da cultura neste específico tópico do processo de socialização. Essa é uma questão que merece maiores aprofundamentos por parte da academia de marketing.

As crianças mais novas afirmam receber informações de novos produtos principalmente de visitas a lojas, já crianças mais velhas indicam que a mídia, principalmente a televisão, é a fonte mais importante de informações sobre novos produtos (WARD e WACKMAN, 1974). Esses resultados apontam que, conforme envelhecem, as crianças se tornam mais conscientes do papel da mídia como fonte de informações sobre produtos e serviços.

Cabe aqui colocar as considerações de Moses e Baldwin (2005). Os autores consideram que não basta a criança ter o conhecimento dos conceitos relacionados ao entendimento do que é uma propaganda, mas tem que também saber utilizar esses conceitos em ocasiões reais. Dessa forma, não seria o bastante a criança entender que o comercial traz informações sobre produtos e serviços ou que o comercial tem como objetivo vender alguma coisa. A criança teria que colocar esses conceitos em prática na hora de avaliar determinado apelo, para assim tomar decisões de consumo mais adequadas.

A mídia de massa tem sua influência mediada pelo comportamento dos pais. De acordo com Neeley (2005), os pais podem influenciar o impacto da mídia quando compartilham com a criança o momento de interação com uma determinada mídia. Isso acontece com maior freqüência na mídia televisiva, por ser consumida em grupo. Nesse sentido, existem alguns momentos em que os pais podem influenciar o impacto da mídia televisiva, como por exemplo, a escolha dos programas que irão assistir no momento em que os filhos estão presentes, os comentários realizados sobre o que está sendo televisionado (programas e propagandas) e as atitudes dos pais perante as propagandas.

Conforme as crianças vão crescendo, a sua liberdade para escolher livremente os programas que irá assistir aumenta (NEELEY, 2005). Isso indica claramente que o impacto dos pais, como 
mediadores da influência da mídia, decresce com o passar dos anos. Outro fator que indica o decréscimo do impacto dos pais é a presença cada vez maior de televisores no quarto das crianças. Atualmente $52 \%$ dos lares americanos apresentam televisores no quarto das crianças (ROBERTS, 2007), diminuindo assim o papel dos pais no processo. 


\section{MÉTODOLOGIA DA PESQUISA DE CAMPO}

Após haver realizado a pequisa bibliográfica, identificou-se a necessidade da condução de uma pesquisa de campo. A incapacidade de resposder o problema de por meio da revisão teórica, indica a existência de uma lacuna na teoria de marketing que necessita ser preenchida, o que pode começar a ser feito por meio de estudos iniciais e exploratórios no tema. Desta forma, esta etapa do trabalho buscará apresentar a escolha do método de pesquisa mais apropriado para o tema aqui abordado, apresentando também o desenvolvimento da pesquisa na sua parte mais prática.

\subsection{A escolha do método}

Inicia-se este tópico com uma frase de Albert Einstein (PATTON, 2002, p.12): "Nem tudo que pode ser contado conta, e nem tudo que conta pode ser contado." Ao pensar em alternativas de desenho da pesquisa e de escolhas metodológicas surge a necessidade de analisar as forças e fraquezas de cada uma das vertentes, tanto qualitativas, como quantitativas (PATTON, 2002; BABBIE, 2000). As colocações de Einstein iluminam essa questão, deixando claro que cada objetivo de pesquisa deve ser analisado de forma isenta, para que, com base nas características do problema em questão, seja definido o método mais adequado (CAMPOMAR, 1991), sem deixar de lembrar que, em alguns casos, a questão de pesquisa pode ser respondida com o uso de diferentes métodos de forma conjunta (PATTON, 2002).

Para este trabalho, optou-se por utilizar uma linha de pesquisa qualitativa, descrita por Campomar (1991, p. 96) da seguinte forma: “[...] nos métodos qualitativos não há medidas, as possíveis inferências não são estatísticas e procura-se fazer análises em profundidade, obtendo-se até as percepções dos elementos pesquisados sobre eventos de interesse". Ao analisar o comentário de Campomar (1991), percebe-se uma clara coerência com o problema de pesquisa aqui proposto. Ao objetivar identificar as estratégias de segmentação e posicionamento adotadas por empresas focadas no consumidor infantil adentra-se uma área em que não se faz necessário o uso do ferramental estatístico, pelo contrário, o objetivo do trabalho fundamenta-se na compreensão dos processos pelo meio dos quais as empresas colocam em prática o conceito de marketing, por meio do processo de segmentação e posicionamento no mercado infantil. Por se tratar de um 
tema ainda inexplorado na academia, percebe-se a necessidade de um tipo de pesquisa que seja caracterizado pela geração flexível de dados, de acordo com o contexto em que a própria empresa está inserida (MASON, 1996).

Diversos autores trataram das questões relacionadas ao método qualitativo e suas diferentes formas, acreditando que são ferramentas adequadas aos pesquisadores envolvidos com o desenvolvimento da pesquisa empírica na área de administração (CAMPOMAR, 1991, MARSHALL e ROSSMAN, 1995, EISENHARDT, 1989; BROMLEY, 1986), reforçando a adequação desta escolha metodológica.

A pesquisa qualitativa busca compreender um determinado fenômeno, por meio de técnicas interpretativas, que objetivam descrever, decodificar, ou traduzir este fenômeno (MAANEN, 1989), buscando uma compreensão mais profunda do mesmo (CAMPOMAR, 1991; MARTIN, 2005). Vale ressaltar também que esse aprofundamento pode vir das palavras, ações ou documentos das pessoas (MAYKUT e MOREHOUSE, 1996). Esse aprofundamento pode ser conseguido por uma série de alternativas: estudo de caso, etnografia, fenomenologia, hermenêutica, entre outros (GLESNE, 1999).

O Quadro 23 traz a visão de Yin (2001) sobre as diferentes opções de pesquisa que se apresentam ao pesquisador, fundamentando a opção deste trabalho pela pesquisa qualitativa por meio do estudo de caso. Essa decisão baseia-se na característica contemporânea do objetivo de estudo e pelo direcionamento dado pelo objetivo geral deste trabalho. Perry (1998) também valida e reforça a opção metodológica deste trabalho ao colocar que acredita que a área de marketing irá se beneficiar profundamente com o uso do método de estudo de caso ao investigar tópicos contemporâneos, sobre os quais pouco foi publicado na área acadêmica. 
Quadro 23 - Situações relevantes para diferentes estratégias de pesquisa

\begin{tabular}{|l|l|c|c|}
\hline Estratégia & $\begin{array}{l}\text { Forma da questão de } \\
\text { pesquisa }\end{array}$ & $\begin{array}{l}\text { Exige controle sobre } \\
\text { eventos comportamentais }\end{array}$ & $\begin{array}{l}\text { Focaliza acontecimentos } \\
\text { contemporâneos }\end{array}$ \\
\hline Experimento & Como, por que & Sim & Sim \\
\hline Levantamento & $\begin{array}{l}\text { Quem, o que, onde, } \\
\text { quantos, quanto }\end{array}$ & Sim/Não \\
\hline $\begin{array}{l}\text { Análise de } \\
\text { Arquivos }\end{array}$ & $\begin{array}{l}\text { Quem, o que, onde } \\
\text { quantos, quando }\end{array}$ & Não & Não \\
\hline Pesquisa Histórica & Como, por que & Não & Sim \\
\hline Estudo de Caso & Como, por que & Não & \\
\hline
\end{tabular}

FONTE: COSMOS CORPORATION apud YIN; 2001, p.24.

As considerações apresentadas anteriormente são complementadas por Marshall e Rossman (1995) no Quadro 24, que é apresentado a seguir. A análise do quadro permite classificar este trabalho como tendo um objetivo explanatório, ou seja, pretendendo explicar como as empresas estão elaborando e colocando em prática estratégias de segmentação e posicionamento no mercado infantil. Sendo assim, a sugestão apresentada pelos pesquisadores permite como decisão válida o uso do método do estudo de caso. 
Quadro 24 - Ligando a questão de pesquisa com a estratégia

\begin{tabular}{|c|c|c|c|}
\hline Objetivo do estudo & Questão de Pesquisa & $\begin{array}{c}\text { Estratégia de } \\
\text { Pesquisa }\end{array}$ & $\begin{array}{c}\text { Exemplos de técnicas } \\
\text { de coleta de dados }\end{array}$ \\
\hline $\begin{array}{l}\text { EXPLORATÓRIO } \\
\text { Investigar fenômenos } \\
\text { pouco entendidos } \\
\text { Identificar ou descobrir } \\
\text { variáveis importantes } \\
\text { Gerar hipóteses para } \\
\text { pesquisas futuras }\end{array}$ & $\begin{array}{l}\text { O que está acontecendo neste programa } \\
\text { social? } \\
\text { Quais são os temas relevantes, os } \\
\text { padrões, categorias nas estruturas de } \\
\text { significado dos participantes? } \\
\text { Quais são os padrões que conectam um } \\
\text { com o outro? }\end{array}$ & $\begin{array}{l}\text { Estudo de caso } \\
\text { Estudo de } \\
\text { campo }\end{array}$ & $\begin{array}{l}\text { Observação participante } \\
\text { Entrevistas em } \\
\text { profundidade } \\
\text { Entrevistas com a elite }\end{array}$ \\
\hline $\begin{array}{l}\text { EXPLANATÓRIO } \\
\text { Explicar as forças que } \\
\text { causam o fenômeno em } \\
\text { questão } \\
\text { Identificar redes causais } \\
\text { plausíveis que moldam o } \\
\text { fenômeno }\end{array}$ & $\begin{array}{l}\text { Quais eventos, crenças, atitudes, } \\
\text { políticas estão moldando o fenômeno? } \\
\text { Como essas forças interagem para } \\
\text { resultar no fenômeno? }\end{array}$ & $\begin{array}{l}\text { Estudo de caso } \\
\text { múltiplo } \\
\text { História } \\
\text { Estudo de } \\
\text { campo } \\
\text { Etnografia }\end{array}$ & $\begin{array}{l}\text { Observação participante } \\
\text { Entrevistas em } \\
\text { profundidade } \\
\text { Questionário } \\
\text { Análise de documentos }\end{array}$ \\
\hline $\begin{array}{l}\text { DESCRITIVO } \\
\text { Documentar o fenômeno } \\
\text { de interesse }\end{array}$ & $\begin{array}{l}\text { Quais são os comportamentos salientes, } \\
\text { eventos, crenças, atitudes, estruturas, } \\
\text { processos ocorrendo neste fenômeno? }\end{array}$ & $\begin{array}{l}\text { Estudo de } \\
\text { campo } \\
\text { Estudo de caso } \\
\text { Etnografia }\end{array}$ & $\begin{array}{l}\text { Observação participante } \\
\text { Entrevistas em } \\
\text { profundidade } \\
\text { Análise de documentos } \\
\text { Medidas não intrusivas } \\
\text { Questionário }\end{array}$ \\
\hline $\begin{array}{l}\text { PREDITIVO } \\
\text { Prever os resultados do } \\
\text { fenômeno } \\
\text { Prever os eventos e } \\
\text { comportamentos } \\
\text { resultantes do fenômeno }\end{array}$ & $\begin{array}{l}\text { O que vai ocorrer como resultado deste } \\
\text { fenômeno? } \\
\text { Quem será afetado? De que forma? }\end{array}$ & $\begin{array}{l}\text { Experimento } \\
\text { Quase- } \\
\text { experimento }\end{array}$ & $\begin{array}{l}\text { Questionário (amostra } \\
\text { grande) } \\
\text { Análise de conteúdo }\end{array}$ \\
\hline
\end{tabular}

FONTE: MARSHALL e ROSSMAN; 1995, p.41.

Feagin et al. (1991, p.2) definem o estudo de caso como "[...] uma profunda, multifacetada investigação, usando métodos de pesquisa qualitativos, de um único fenômeno social", o qual deve ter uma conotação contemporânea (YIN, 2001; PERRY, 1998) e buscar compreender características singulares de uma determinada situação (EISENHARDT, 1989). Perry (1998) complementa Feagin et al. (1991) e propõe que o estudo de caso deve ser compreendido como um método realista que tenta compreender os fenômenos contemporâneos, abordando-os com uma conotação mais descritiva.

Essa percepção de como deve ser encarado o estudo de caso coloca o método como uma ferramenta para a construção de teoria (PERRY, 1998; EISENHARDT, 1998; FEAGIN et al., 1991; STAKE, 1994; CEPEDA e MARTIN, 2005; VOSS et al., 2002; WOODSIDE e WILSON, 2003), conforme explicam Cepeda e Marting (2005): o uso do estudo de caso na administração possibilita o estudo das técnicas administrativas num ambiente natural, possibilitando estar em 
contato com o estado-da-arte e gerar teorias a partir da prática. Além disso, o estudo de caso apresenta outras vantagens que merecem ser salientadas (FEAGIN et al., 1991):

- Permite a fundamentação de observações e conceitos sobre ações sociais e estruturas sociais em ambientes naturais estudados de perto.

- Provê informações de um numero de fontes e sobre certo período de tempo, dessa forma permitindo um estudo mais holístico sobre as complexas relações sociais e sobre ações sociais complexas e significados sociais.

- Pode fornecer dimensões de tempo e história para o estudo da vida social, dessa forma permitindo que o investigador examine a continuidade e as mudanças nos padrões da vida real.

- Encoraja e facilita, na prática, a inovação teórica e a generalização.

A partir das considerações acima, optou-se pela realização de uma pesquisa de campo qualitativa, por meio de um estudo de caso. Bromley (1986) considera que um estudo de caso pode ser válido e confiável, desde que o método seguido seja cientificamente fundamentado. Dessa forma, a partir deste momento do trabalho, procurar-se-á apresentar toda a estratégia de pesquisa adotada para a coleta e análise dos dados.

\subsection{O processo de amostragem na pesquisa qualitativa}

Tendo selecionado o tipo de pesquisa que será utilizada neste trabalho, partiu-se para a seleção das empresas que seriam alvo deste trabalho. Cabe iniciar a discussão sobre a amostragem trazendo as palavras de Maykut e Morehouse (1996). De acordo com os autores o processo de amostragem na pesquisa qualitativa difere da amostragem na pesquisa quantitativa no sentido de que o objetivo é distinto. Na pesquisa qualitativa busca-se selecionar casos que ofereçam o maior 
aprofundamento possível sobre o fenômeno a ser estudado, enquanto na pesquisa quantitativa o objetivo é selecionar casos que representem a população (MAYKUT e MOREHOUSE, 1996).

A amostragem, quando se trata do estudo de caso, é vista por Stake (1998) como um aspecto único em relação a outros métodos de pesquisa. Patton (2002) segue uma linha de raciocínio semelhante e defende que o processo de amostragem na pesquisa qualitativa difere enormemente do processo de amostragem quantitativo. O autor considera que, enquanto os processos de pesquisa quantitativos exigem um processo de amostragem fundamentado nas probabilidades de escolha do caso para análise, o processo de pesquisa qualitativo não é exigente neste sentido.

No entanto, a escolha do caso a ser estudado é critica para o efetivo alcance do objetivo proposto em uma pesquisa qualitativa (PATTON, 2002; YIN, 2001, MARSHALL e ROSSMAN, 1995). A escolha do caso, ou dos casos a serem estudados, irá moldar todo o processo posterior da pesquisa e, por isso, deve ser uma decisão tomada com muito cuidado, sendo justificada e descrita de forma muito clara (MARSHALL e ROSSMAN, 1995).

Já para Maykut e Morehouse (1996), a questão da amostragem em pesquisa qualitativa é percebida como um processo cuidadoso de escolha de casos que aumentem a variabilidade dos dados. Assim, deve ser objetivo do pesquisador encontrar casos que tragam o maior número de informações sobre o fenômeno em questão.

Diante dessas considerações, este trabalho buscou identificar uma série de casos que poderiam trazer diferentes visões sobre o problema de pesquisa proposto. Sendo assim, procurou-se abordar empresas que tivessem características bastante diferentes, tanto no seu tamanho, como no público atendido, como no portfolio de produtos apresentados.

\subsubsection{Escolha do setor e das empresas pesquisadas}

São inúmeros os setores onde empresas centradas no desenvolvimento de produtos e serviços para o mercado infantil atuam. Dentre as várias opções de enfoque que a pesquisa de campo poderia ter, este trabalho asserta que o setor de brinquedos é um dos mais concentrados no 
atendimento ao público infantil. Acredita-se que, a escolha pelo setor de brinquedos possibilita uma análise mais adequada das estratégias sendo desenvolvidas e implementadas no processo de atendimento do consumidor infantil e, sendo assim, poderá trazer informações mais ricas para a pesquisa de campo.

Um dos grandes desafios da pesquisa qualitativa é negociar a entrada (MARSHALL e ROSSMAN, 1995; PATTON, 2002; MAYKUT e MOREHOUSE, 1996). Essa situação é ainda mais crítica quando se trata do estudo de organizações, sendo exigida, nestes casos, uma dedicação e uma persistência adicional junto aos lideres formais da organização (MARSHALL e ROSSMAN, 1995). Babbie (2000) sugere que o pesquisador dedique esforços para conhecer o grupo ou a organização junto a qual pretende desenvolver sua pesquisa. A partir daí, sugere o autor, seria necessário estabelecer contato com um integrante do grupo, para assim ganhar um determinado nível de apoio nos primeiros momentos de incursão no campo.

Este trabalho, como muitos outros que optam por estudar organizações e suas estratégias mercadológicas enfrenta uma série de problemas relacionados à indisponibilidade de participar de uma pesquisa, liberação de dados considerados sigilosos e até mesmo a falta de tempo para disponibilizar para pesquisadores. Ciente dessas dificuldades optou-se pela contratação de uma assistente de pesquisa para ter um esforço de contato mais incisivo. Selecionou-se uma assistente com formação em Administração de Empresas e Especialização na Área de Marketing. O papel da assistente restringiu-se ao contato com as empresas e a coleta de dados, ou seja, ela realizou todos os contatos necessários com as empresas para agendar as entrevistas. Além disso, a assistente também participou das entrevistas cuidando da parte operacional de gravar e transcrever as entrevistas.

Identificou-se que a base de dados oferecida pela Abrinq (2007) poderia ser uma fonte interessante para o início dos contatos com as empresas do setor de brinquedos. No total, foram contatadas 80 empresas que fazem parte do cadastro da Abrinq e que estão localizadas na Grande São Paulo. Esse recorte se fez necessário em função de restrições temporais e financeiras. A base de dados correspondente a estas empresas somou 80 potenciais casos. Tentou-se estabelecer contatos telefônicos com todas as 80 empresas, porém isso só foi possível com 53 empresas, pois 
27 empresas apresentavam problemas cadastrais (telefone inexistente) ou indisposição em participar (email não retornado). Os contatos com as 53 empresas foram realizados por telefone, sendo seguidos pelo envio de um email com as explicações necessárias e as principais características da pesquisa (Vide Anexo 1). Esses contatos foram realizados ao longo de duas semanas. Das empresas contatadas, diversas recusaram a participação na pesquisa por motivos diversos, como pela falta de tempo dos seus gestores e, como no caso da Mattel, por restrições impostas pela matriz norte-americana. Como resultado final deste esforço, foi possível marcar entrevistas com 3 empresas, a citar a Grow Brinquedos, a Mitra Officina de Criação e a Brinquedos Pica Pau.

A escolha por realizar casos paralelos é fundamentada nas orientações de Einsenhardt (1989; 1991). A autora considera que, ao utilizar diversos casos, é possível usar cada um dos casos adicionais para corroborar os achados dos anteriores, seguindo uma trilha de desenvolvimento de teoria, com etapas sucessivas de replicações e extensões. Apesar de existirem críticas ao uso de casos múltiplos (DYER e WILKINS, 1991), este trabalho apóia-se nas considerações de Eisenhardt (1989; 1991) para justificar a escolha do estudo de caso múltiplo. Também se considerou que, ao utilizar como fontes de dados empresas com características dispares, seria possível conduzir uma análise de dados comparativa muito mais rica em informações pertinentes ao objetivo deste trabalho. $\mathrm{O}$ uso de casos múltiplos também pode ser considerado como uma forma de aumentar a confiabilidade de um estudo de caso, pois, ao conduzir estudos de caso simultâneos sobre o mesmo fenômeno, aumenta-se a capacidade de identificar padrões que se repetem e padrões únicos em cada caso (FEAGIN et al., 1991).

Yin (2001) indica claramente que a pesquisa qualitativa exige muito mais do pesquisador em comparação com um experimento ou levantamento. $\mathrm{O}$ autor considera que, nos estudos de caso, quase não existe a opção de contar com assistentes de pesquisa, sendo responsabilidade do pesquisador conduzir a coleta e a análise dos dados. Além disso, também é papel do cientista social, especialmente aquele mais experiente, conduzir mudanças ao longo do processo de coleta de dados, aproveitando oportunidades inesperadas (YIN, 2001). Yin (2001, p.81) lista uma série de qualidade que seriam comumente exigidas de um bom pesquisador: 
- Uma pessoa capaz de fazer boas perguntas - e interpretar as respostas.

- Uma pessoa deve ser uma boa ouvinte e não ser enganada por suas próprias ideologias e preconceitos.

- Uma pessoa deve ser capaz de ser adaptável e flexível, de forma que as situações recentemente encontradas possam ser vistas como oportunidades, não ameaças.

- Uma pessoa deve ter uma noção clara das questões que estão sendo estudadas, mesmo que seja uma orientação teórica ou política, ou que se de um modo exploratório. Essa noção tem como foco os eventos e as informações relevantes que devem ser buscadas a proporções administráveis.

- Uma pessoa deve ser imparcial a noções preconcebidas, incluindo aquelas que se originam de uma teoria. Assim, uma pessoa deve ser sensível e estar atenta a provas contraditórias.

Numa pesquisa qualitativa, o pesquisador é o instrumento (MARSHALL e ROSSMAN, 1995; PATTON, 2002; MAYKUT E MOREHOUSE, 1996), enquanto numa pesquisa quantitativa o instrumento é um questionário, uma escala, ou outros itens que possam ser utilizados para medir algum fenômeno (PATTON, 2002). Diante disso, agrega o autor, a credibilidade dos métodos qualitativos depende principalmente das habilidades, competências, e do rigor da pessoa conduzindo o trabalho de campo. A importância do pesquisador deriva do papel duplo que ele assume, de coletor dos dados e de responsável por abstrair o significado dos dados coletados (MAYKUT e MOREHOUSE, 1996).

A partir das considerações acima, percebe-se a importância do desenvolvimento de um referencial teórico que dê base para o pesquisador conduzir a coleta de dados de forma correta, realizando mudanças quando necessário e tendo a capacidade de abstrair significado dos dados coletados. O pesquisador responsável por este trabalho dedicou um considerável esforço para criar um referencial teórico amplo e profundo o bastante para gerar a familiaridade necessária para a condução das entrevistas. Além disso, foi realizado um processo de análise inicial dos primeiros resultados encontrados na primeira entrevista, visando à inclusão de questionamentos a

partir dessas informações iniciais. É possível dizer que foi o processo cíclico de condução de entrevistas que permitiu o surgimento de algumas análises comparativas, fato que não seria possível caso todas as entrevistas fossem conduzidas com base no mesmo roteiro.

\subsection{Coleta de dados}

O pesquisador qualitativo objetiva entender as experiências das pessoas em determinado contexto, ou seja, é num ambiente natural que o pesquisador estará apto a descobrir ou encontrar 
o que deve ser compreendido sobre o fenômeno (MAYKUT e MOREHOUSE, 1996). Dessa forma, o processo de coleta de dados deve ser direcionado pelo contexto onde o pesquisador se insere. As decisões sobre quais são as técnicas mais apropriadas decorre de uma profunda análise do contexto da pesquisa, sendo assim não existe uma indicação a priori das melhores opções de coleta de dados.

A coleta de dados no estudo de caso pode ser feita por meio de entrevistas (individuais ou em grupo), observação participante e coleta de documentos (escritos ou visuais) e questionários abertos (GLESNE, 1998; MASON, 1996; MARSHALL e ROSSMAN, 1995; MAYKUT e MOREHOUSE, 1996; EISENHARDT, 1989; SILVERMAN, 1995). A nomenclatura utilizada na literatura pode variar de acordo com o autor, mas, de forma geral, as técnicas mais utilizadas na pesquisa qualitativas são as apresentadas anteriormente. Mason (1996, p.36-37) propõe uma série de exemplos das diversas opções de fontes de dados que tornam mais clara as opções do pesquisador:

Pessoas, discursos, linguagem, escritos, textos, narrativas, histórias, artes, produtos culturais, imagens visuais, diagramas, fotografias, mapas, publicações, produtos de mídia, documentos, arquivos, leis, estatutos, regras, regulamentos, políticas, coletividades, grupos, clubes, organizações, eventos, locações sócio-geográficas.

Yin (2001) especifica de forma mais profunda as fontes de evidência que podem ser utilizadas no método do estudo de caso: 
Quadro 25 - Seis fontes de evidência: pontos fortes e pontos fracos

\begin{tabular}{|c|c|c|}
\hline $\begin{array}{l}\text { Fontes de } \\
\text { evidências }\end{array}$ & Pontos fortes & Pontos fracos \\
\hline Documentação & $\begin{array}{l}\text { - Estável - pode ser revisada inúmeras } \\
\text { vezes. } \\
\text { - Discreta - não foi criada como } \\
\text { resultado do estudo de caso } \\
\text { - Exata - contém nomes, referências e } \\
\text { detalhes exatos de um evento } \\
\text { - Ampla cobertura - longo espaço de } \\
\text { tempo, muitos eventos e muitos } \\
\text { ambientes distintos }\end{array}$ & $\begin{array}{l}\text { - Capacidade de recuperação pode ser baixa } \\
\text { - Seletividade tendenciosa, se a coleta não } \\
\text { estiver completa } \\
\text { - Reflete as visões tendenciosas - reflete idéias } \\
\text { pré-concebidas (desconhecidas) do autor } \\
\text { - Acesso - pode ser deliberadamente negado }\end{array}$ \\
\hline $\begin{array}{l}\text { Registro em } \\
\text { arquivos }\end{array}$ & $\begin{array}{l}\text { - }[\text { os mesmos mencionados para } \\
\text { documentação] } \\
\text { - Precisos e quantitativos }\end{array}$ & $\begin{array}{l}\text { - [os mesmos mencionados para documentação] } \\
\text { - Acessibilidade aos locais graças a razões } \\
\text { particulares }\end{array}$ \\
\hline Entrevistas & $\begin{array}{l}\text { - Direcionados - enfocam diretamente } \\
\text { o tópico do estudo de caso } \\
\text { - Perceptivas - fornecem inferências } \\
\text { causais percebidas }\end{array}$ & $\begin{array}{l}\text { - Visão tendenciosa devido a questões mal- } \\
\text { elaboradas } \\
\text { - Respostas tendenciosas } \\
\text { - Ocorrem impressões devido à memória fraca } \\
\text { do entrevistado } \\
\text { - Reflexividade - o entrevistado dá ao } \\
\text { entrevistador o que ele quer ouvir }\end{array}$ \\
\hline $\begin{array}{l}\text { Observações } \\
\text { diretas }\end{array}$ & $\begin{array}{l}\text { - Realidade - tratam de } \\
\text { acontecimentos em tempo real } \\
\text { - Contextuais - tratam do contexto do } \\
\text { evento }\end{array}$ & $\begin{array}{l}\text { - Consomem muito tempo } \\
\text { - Seletividade - salvo ampla cobertura } \\
\text { - Reflexividade - o acontecimento pode ocorrer } \\
\text { de forma diferenciada porque está sendo } \\
\text { observado } \\
\text { - Custo - horas necessárias pelos observadores } \\
\text { humanos }\end{array}$ \\
\hline $\begin{array}{l}\text { Observação } \\
\text { participante }\end{array}$ & $\begin{array}{l}\text { - }[\text { as mesmas mencionados } \\
\text { observação direta] } \\
\text { - Perceptiva em }\end{array}$ & $\begin{array}{l}\text { - [os mesmos mencionados para observação } \\
\text { direta] } \\
\text { - Visão tendenciosa devido a manipulação dos } \\
\text { eventos por parte do pesquisador }\end{array}$ \\
\hline $\begin{array}{l}\text { Artefatos } \\
\text { físicos }\end{array}$ & $\begin{array}{l}\text { - Capacidade de percepção em relação } \\
\text { a aspectos culturais } \\
\text { Capacidade de percepção em relação a } \\
\text { operações técnicas }\end{array}$ & $\begin{array}{l}\text { - Seletividade } \\
\text { - Disponibilidade }\end{array}$ \\
\hline
\end{tabular}

FONTE: YIN; 2001, p.108.

Este trabalho optou por coletar os dados necessários por meio da técnica de entrevistas em profundidade, que é uma das mais utilizadas pelos pesquisadores qualitativos (MARSHALL e ROSSMAN, 1995). De forma geral, agregam os autores, a entrevista em profundidade se parece muito com um conversa informal. O pesquisador irá explorar alguns poucos tópicos, buscando entender a perspectiva do entrevistado (MARSHALL e ROSSMAN, 1995). Maykut e Morehouse (1996) salientam que, em alguns casos, podem ocorrer entrevistas informais onde o respondente não está totalmente ciente de estar sendo entrevistado, fato natural decorrente da informalidade da conversa. 
O papel do pesquisador, ao conduzir uma entrevista em profundidade, é transformar o respondente em um informante (YIN, 2001). A diferença entre respondente e informante é que o segundo exige um maior envolvimento do indivíduo, fornecendo maiores detalhes, sugerindo outras fontes para corroborar as suas colocações (YIN, 2001). As entrevistas podem ser conduzidas de forma espontânea, conforme sugerido por Marshall e Rossman (1995), ou podem ter um caráter mais estruturado (YIN, 2001). O primeiro caso é mais utilizado em situações onde o pesquisador está mais envolvido no ambiente onde ocorre o fenômeno, o segundo caso ocorre quando o pesquisador entra em contato com as pessoas de forma mais organizada, mas em ambos os casos o protocolo tem um papel fundamental para direcionar a conversa (YIN, 2001). Mesmo que o pesquisador não vá a campo com uma lista de questões escritas numa folha de papel, ele deve ao menos estar com os questionamentos que pretende fazer bem claros na memória, possibilitando assim o desenvolvimento de uma entrevista com certa naturalidade.

Maykut e Morehouse (1996) sugerem que a entrevista, nos casos mais estruturados e formais, tenha duração entre uma hora e meia e duas horas, permitindo assim um maior envolvimento entre o pesquisador e o entrevistado. Esse período de tempo permite a criação de um clima de confiança entre os participantes, abrindo espaço para a coleta de dados mais profundos. Os autores também sugerem o uso de múltiplas sessões de entrevistas, o que serve para aprofundar alguns tópicos ou, conforme indica Glesne (1998), aumentar a validade das descobertas por meio da confirmação dos dados. Apesar das sugestões acima certamente terem um papel relevante na consecução dos objetivos desta pesquisa, não foi possível realizar múltiplas sessões de entrevista em razão da indisponibilidade dos entrevistados para o mesmo. Além disso, considerou-se que a coleta de dados por meio de uma entrevista única trouxe os elementos necessários para o desenvolvimento do trabalho.

Para este trabalho, procurou-se realizar entrevistas com os gestores da empresa ou da área de marketing, pois são estes os integrantes da organização que têm acesso às informações que este trabalho busca coletar. Sendo assim, foram conduzidas entrevistas com: 
- Brinquedos Pipa Pau: Entrevista realizada com o Sr. Tadeu Ribeiro, Gerente de Vendas da empresa há 4 anos, tendo já 25 anos de experiência no ramo de brinquedos. Formação universitária no curso de Administração.

- Grow Brinquedos: entrevista realizada com o Sr. Gustavo Arruda, Gerente de Marketing da empresa. O entrevistado está na empresa há 9 anos, tendo iniciado sua carreira na empresa como estagiário, passando para assistente de produto, depois para gerente de produto e atualmente atuando como gerente de marketing.

- Mitra Oficina de Brinquedos: entrevista realizada com o Sr. Jorge Massao Takehara (engenheiro de produção) e Marta Giardani (pedagoga e artista plástica) sóciosproprietários da empresa.

As entrevistas tiveram uma duração média de uma hora. Todas as entrevistas foram transcritas, gerando uma base de dados que foi utilizada para a realização da análise dos dados. A coleta de dados foi realizada tomando-se como base o roteiro de entrevista (APÊNDICE 4), o qual foi construído tomando-se como base a revisão teórica apresentada no capítulo 2 deste trabalho.

\subsection{Análise dos dados}

A análise dos dados deve estar focada no entendimento do significado das palavras e ações dos indivíduos (MAYKUT e MOREHOUSE, 1996). O processo é basicamente indutivo, abstraindose dos dados os significados. Essas características dão fundamento às críticas feitas por autores, principalmente aqueles defensores do método quantitativo, sobre o viés que é introduzido pelo pesquisador na coleta e na análise dos dados (DENZIN e LINCOLN, 1994). Reconhece-se que existe sim uma dificuldade na condução de uma análise de dados, principalmente quando estes se referem ao discurso dos indivíduos.

Eisenhardt (1989) e Maykut e Morehouse (1996) procuram incentivar a realização simultânea da coleta de dados e da análise dos dados. Esse processo conjunto permitiria uma análise melhor das informações sendo coletadas e um foco mais apropriado para as etapas posteriores de coleta de dados. Essa situação explica o conceito de estratégia emergente de pesquisa, pois surge ai um 
processo cíclico, aonde os dados coletados vão gerando insumos que justificam outras coletas com outros focos, buscando sempre o aprofundamento da compreensão do fenômeno. As sugestões dos autores foram seguidas, pois a partir do primeiro caso estudado, foram sendo introduzidas questões que solicitavam aos entrevistados uma análise comparativa das iniciativas conduzidas pelas empresas anteriormente consultadas. Esta estratégia demonstrou ser bastante interessante, pois trouxe como resultado comparações entre os casos estudados sob a perspectiva dos próprios entrevistados, tanto sobre as estratégias adotadas pelas empresas, como para considerações sobre o mercado de brinquedos como um todo e para as questões relativas à segmentação e posicionamento.

Para Eisenhardt (1989), a análise dos casos deve ser feita em duas etapas: primeiramente analisase cada caso individualmente, para posteriormente avaliar os casos de forma conjunta. Esse processo realizado individualmente é geralmente feito por meio de descrições detalhadas do caso (EISENHARDT, 1989). A autora lamenta a não existência de um método mais estruturado para a análise dos casos, mas acrescenta que a idéia de descrever detalhadamente cada um dos casos torna o pesquisador mais familiarizado com os dados, permitindo, assim, uma análise posterior dos casos em conjunto. A necessidade de o pesquisador estar totalmente familiarizado com os dados também é colocada por Marshall e Rossman (1995) como fator fundamental para a correta análise dos dados. Sendo assim, este trabalho optou por analisar cada caso individualmente, para realizar posteriormente uma análise conjunta com um caráter comparativo.

Ao estudar e descrever cada caso individualmente, o pesquisador tornará possível o aparecimento dos padrões de comportamento específicos do caso em questão (EISENHARDT, 1989). Quando esses padrões aparecem em outros casos é que se obtém a capacidade de iniciar as reflexões sobre possíveis generalizações. Para coordenar esta etapa do trabalho, Marshall e Rossman (1995) sugerem o uso de categorias, temas ou padrões, mas reconhecem que infelizmente existem poucos trabalhos na literatura que foquem na descrição de métodos para realizar este processo. De qualquer forma, os autores sugerem que se tenha um alto conhecimento da base de dados, que se mantenha uma completa atenção ao processo, que se seja aberto para as nuances que podem estar presentes em cada coleta. De acordo com as sugestões acima, optou-se por utilizar uma 
análise de dados dividida em categorias, as quais possibilitam uma melhor compreensão dos casos individualmente, além de uma facilidade maior na análise comparativa dos casos.

Eisenhardt (1989) chama atenção para a necessidade de não incorrer em erros durante a análise comparativa dos casos. O perigo está no excesso de informações que podem levar o pesquisador a fazer análises errôneas. Por isso, a autora sugere o uso de categorias de análise para tornar o processo mais fácil de ser conduzido. Essas categorias podem surgir a partir dos próprios casos, a partir da literatura ou por decisão do pesquisador (EISENHARDT, 1989). As categorias utilizadas neste trabalho são fundamentadas nos casos estudados e na literatura que fundamentou a revisão teórica apresentada anteriormente. Essas categorias estão presentes nos tópicos que constituem a análise de cada caso.

Outra opção para melhorar a qualidade da análise dos dados, é criar listas de semelhanças e diferenças entre pares de casos (EISENHARDT, 1989). Essa tática de análise força o pesquisador a se aprofundar ainda mais na análise dos dados, criando um entendimento mais sofisticado. Yin (2001) também traz considerações sobre o processo de análise dos dados, sugerindo a técnica de adequação ao padrão, que constitui uma análise entre os dados levantados na pesquisa de campo e o referencial teórico disponível.

Com base nas considerações apresentadas este trabalho apresenta a seguir as principais considerações relacionadas às análises dos dados:

- Primeiramente será conduzida uma análise individual de cada caso, para posteriomente conduzir uma análise comparativa dos casos.

- A análise individual e comparativa será dividida em categorias, selecionadas a partir do referencial teórico.

- As análises serão conduzidas tendo especial atenção para realizar comparações entre o referencial teórico, que apresenta as considerações da literatura sobre os tópicos de segmentação e posicionamento, com as atividades das empresas.

- Cada tópico da análise individual dos casos será finalizado com as principais considerações sobre o caso em questão. Posteriormente, essas considerações principais 
serão agrupadas para gerar uma série de quadros que resumem os principais achados de pesquisa relacionados ao tópico em questão. Esses quadros constituirão a base para a análise comparativa dos casos.

- Ao final de cada caso individual será elaborada uma figura que representa as atividades de segmentação e posicionamento da empresa sendo analisada. 


\section{RESULTADOS DA PESQUISA DE CAMPO}

Nesta etapa do trabalho serão apresentados os resultados da pesquisa de campo realizada com o objetivo de responder a questão de pesquisa proposta inicialmente: Quais são as diferentes estratégias de segmentação e posicionamento adotadas por empresas focadas no mercado infantil?

Esta fase inicia com uma descrição do setor estudado. É objetivo desta descrição apresentar ao leitor o setor de brinquedos, permitindo assim uma melhor compreensão dos casos que serão apresentados posteriormente. O tópico segue com a apresentação individual de cada pesquisado. Finaliza-se este tópico com uma análise comparativa, etapa inerente ao estudo de casos mútiplos.

\subsection{Setor de brinquedos}

O setor de brinquedos no Brasil é representado pela Associação Brasileira de Fabricantes de Brinquedos-ABRINQ. A associação conta com 152 empresas associadas (ABRINQ, 2007). Abaixo são apresentados alguns dados referentes ao faturamento do setor, contando produtos fabricados nacionalmente e produtos importados.

\begin{tabular}{|c|c|c|c|c|c|}
\hline Ano & 2004 & 2005 & 2006 & 2007 & 2008 \\
\hline Faturamento de Produção Nacional & 723 & 808 & 856 & 867 & 940 \\
\hline Faturamento de Importações & 356 & 507 & 822 & 1.367 & 1.572 \\
\hline Total & $\begin{array}{l}1079 \\
\text { ABRI }\end{array}$ & $\begin{array}{l}1315 \\
008 .\end{array}$ & 1678 & 2234 & 2512 \\
\hline
\end{tabular}

* Previsão para 2008

Percebe-se a partir da tabela acima, que o crescimento do setor está sendo bastante satisfatório nos útlimos anos, com uma maior importância dos brinquedos importados, que sobrepassaram o faturamento dos brinquedos nacionais de forma significativa no período. A seguir são apresentados dados referentes ao número de funcionários do setor. 
Tabela 7 - Número de Funcionários da Indústria Nacional

\begin{tabular}{lrrrrr} 
Ano & $\mathbf{2 0 0 4}$ & $\mathbf{2 0 0 5}$ & $\mathbf{2 0 0 6}$ & $\mathbf{2 0 0 7}$ & $\mathbf{2 0 0 8}^{*}$ \\
Funcionários Próprios & 16.000 & 15.600 & 15.000 & 18.120 & \\
Funcionários Terceirizados & 4.000 & 4.000 & 4.000 & 4.520 & \\
\hline Total & 20.000 & 19.600 & 19.000 & 22.640 & 24.000 \\
& FONTE: ABRINQ; 2008. \\
* Previsão para 2008 & & &
\end{tabular}

O número de funcionários do setor também tem crescido bastante, apesar da produção nacional ter se estabilizado por volta das 900 milhões de faturamento. O ano de 2007, período em que houve um crescimento na economia, representa um salto para o setor, passando de 15.000 funcionários próprios para 18.120.

O lançamento de brinquedos teve um grande crescimento no ano de 2006, e uma sensível queda em 2007. A previsão do setor para 2008 reflete uma percepção de crescimento de do número de lançamentos.

\begin{tabular}{|c|c|c|c|c|c|}
\hline Ano & 2004 & 2005 & 2006 & 2007 & $2008 *$ \\
\hline \multicolumn{6}{|l|}{ Quantidade de Brinquedos } \\
\hline Novos Lançados & $\begin{array}{r}1.200 \\
\text { FONTE: A } \\
\text { * Previsã }\end{array}$ & $\begin{array}{c}1.458 \\
\text { JQ; } 200 \\
\text { ra } 2008\end{array}$ & 1.834 & 1.200 & 1.500 \\
\hline
\end{tabular}

Esses brinquedos lançados são divididos conforme a sua utilidade para a criança:

Tabela 9 - Segmentação das Vendas por Grupos

\begin{tabular}{lrrrr} 
Ano & $\mathbf{2 0 0 4}$ & $\mathbf{2 0 0 5}$ & $\mathbf{2 0 0 6}$ & $\mathbf{2 0 0 7}$ \\
Desenvolvimento Afetivo & 32,4 & 40,5 & 23 & 26,1 \\
Primeira Idade & 14,5 & 16,8 & 16 & 11,8 \\
Mundo Técnico & 9,6 & 7 & 5 & 6,5 \\
Atividades Físicas & 12,6 & 12 & 17 & 10 \\
Atividades Intelectuais & 7,1 & 8,4 & 14 & 16,2 \\
Criatividade & 15,4 & 8,5 & 11 & 12,1 \\
Relações Sociais & 8,4 & 6,8 & 14 & 17,2 \\
\hline Total & 100 & 100 & 100 & 100
\end{tabular}

FONTE: ABRINQ; 2008.

As vendas apresentadas anteriormente são distribuídas em três datas ou períodos principais. $\mathrm{O}$ Natal, que representa 31\% das vendas anuais, os Aniversários de crianças, que contam com 34\% das vendas e o Dia da Criança, que responde por 35\% (ABRINQ, 2005) do setor. Os dados apresentados pela associação não levam em conta os brinquedos comprados sem nenhuma 
relação com o aniversário da criança. Talvez os brinquedos dados de presente sem uma data em particular para justificar isso tenham sido incluídos no item aniversários, o que claramente deve ser configurado como um erro de julgamento.

O primeiro lugar em vendas do setor é o Dia da Criança, que é comemorado no dia 12 de outubro. Esta data comemorativa foi proposta na década de 20 pelo então presidente Arthur Bernardes $^{31}$. Em 1960, as empresas Johnson \& Johnson e Estrela foram pioneiras no uso da data como incentivador de vendas, passando a ser, desde então, uma época muito prolífera para lojistas e fabricantes de brinquedos (TERRA, 2004, FOLHA, 2007).

De acordo com dados da ABRINQ (2006), ocorrem diariamente cerca de 138.000 aniversários. Representando, assim, um mercado significativo para as empresas do setor, por ser a data que está no segundo lugar como a geradora de vendas do ramo.

Em terceiro lugar, como data mais importante para o comércio e para os fabricantes de brinquedos, aparece o natal, com $31 \%$ das vendas.

Para 2006, a produção estimadas de brinquedos era de 130 milhões de unidade, contra as 115 milhões de unidades produzidas em 2005 (ABRINQ, 2007). Grande parte deste crescimento foi gerado por brinquedos de até $\mathrm{R} \$ 30,00$, destinados às classes $\mathrm{C}$ e $\mathrm{D}$, que até então não tinham uma participação efetiva no setor (ABRINQ, 2007).

Uma das grandes preocupações da indústria é a questão das importações. De acordo com a Abrinq (2007), existe uma grande quantidade de brinquedos que é importada por meios ilegais, burlando a fiscalização e não pagando impostos, tornando assim a competição desigual. Essa situação vem mudando, pois diversas iniciativas estão sendo realizadas para coibir este tipo de atividade (ABRINQ, 2007).

\footnotetext{
${ }^{31}$ A lei foi criada por decreto (n. ${ }^{04867), ~ n o ~ d i a ~} 5$ de novembro de 1924.
} 


\subsection{Caso 1 - Brinquedos Pica Pau}

Empresa foi fundada em 1962, atuando desde então no mercado de brinquedos. A Pica Pau se coloca como uma das pioneiras do ramo de brinquedos no Brasil, tendo sido uma das poucas que conseguiu sobreviver à invasão de produtos de origem Chinesa. De acordo com o entrevistado, essa condição de sobrevivente é decorrente da estratégia da empresa de trabalhar com produtos populares, tentando obter ganhos de produtividade para se manter competitivo no mercado. $\mathrm{O}$ entrevistado considera que existem públicos para todos os tamanhos de bolso, e a empresa foca realmente nesse público que o entrevistado denomina de popular.

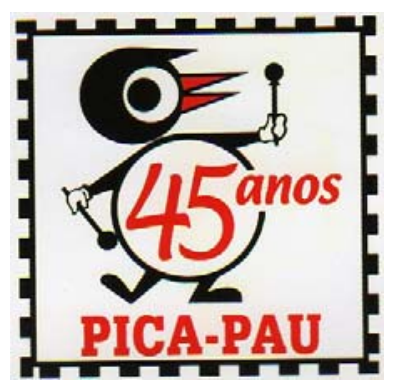

Ilustração 22 - Logotipo comemorativo - Brinquedos Pica Pau

FONTE: Material fornecido pela empresa

A empresa transparece uma firme imagem nacionalista, que pode ser abstraída da frase exposta no site - Brinquedos Pica Pau, Uma Empresa Genuinamente Brasileira - e da figura que consta no site e nos produtos fabricados pela empresa, conforme observa-se a seguir na Ilustração 23:

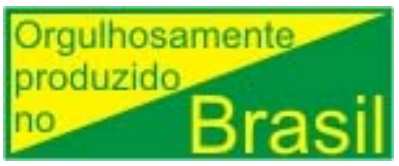

Ilustração 23 - Brinquedos Pica Pau - Orgulho

Fonte: Material fornecido pela empresa

\subsubsection{Estratégia de segmentação}

O processo de segmentação deve ser iniciado com a elaboração de uma pesquisa de segmentação que tem como objetivo primordial recolher informações que possibilitem a correta análise da composição do mercado, permitindo a identificação de segmentos que tenham necessidades similares e que reajam de forma similar aos estímulos de marketing (BRADLEY, 2003). A 
empresa Pica Pau não realiza pesquisas de nenhum tipo, afora alguns testes de produtos que são feitos com filhos de funcionários. Tanto o processo de desenvolvimento de produtos, como o de identificação do público-alvo, é conduzido por meio do feeling dos gestores da empresa.

Talvez, em um primeiro momento de funcionamento da empresa, quando da sua fundação, por exemplo, procurou-se identificar os segmentos que seriam atendidos pela empresa. Naquela época, decidiu-se pelo segmento popular, que, segundo o informante, buscam produtos com valores inferiores a catorze (14) ou quinze (15) reais. É interessante notar que a empresa está expandindo sua linha de produtos para segmentos bastante diferentes daqueles em que estava acostumada a trabalhar, como os produtos das linhas Recém Nascidos, Móbile e Chocalho, direcionados a crianças de até 2 anos. Contudo, apesar da inexperiência na venda de produtos desta categoria, a Pica Pau não direcionou esforços de pesquisa para este novo segmento de atuação (vide Ilustração 24).

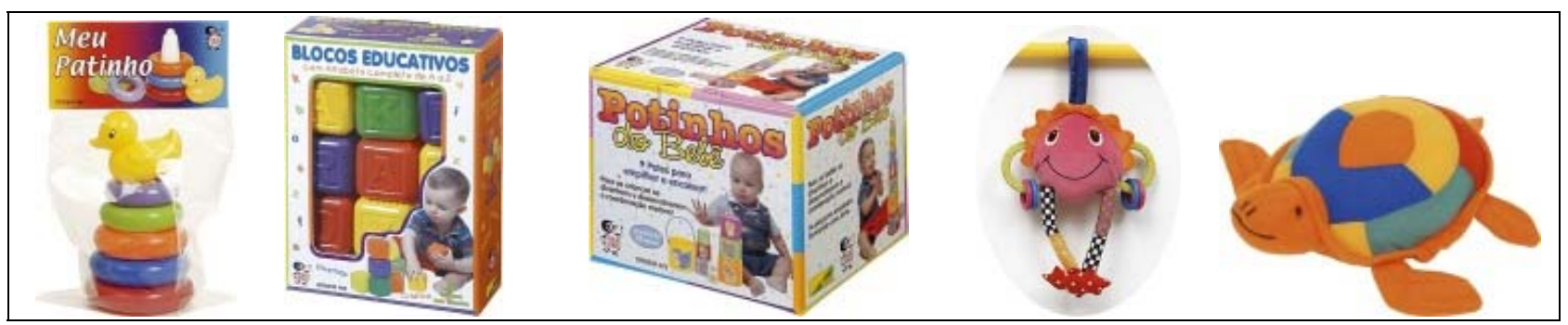

Ilustração 24 - Brinquedos para crianças até 2 anos FONTE: PICA PAU; 2008.

A escolha pela estratégia de difusão, tratando o mercado como se tivesse características similares, pode ser direcionada por questões econômicas (BRANDT, 1966; HOOLEY e SAUNDERS, 1996). O fato pode ser explicado caso a companhia identifique ganhos de escala ao desenvolver um composto de marketing único, tentando assim captar uma parcela de cada um dos prováveis segmentos que compõem o mercado (HOOLEY e SAUNDERS, 1996). Lambin (2000) considera que este tipo de estratégia não é recomendável, mas em alguns casos é possível que essa seja a mais adequada.

O entrevistado apresenta alguns números referentes ao nível de vendas dos diferentes produtos, indicando que a venda de produtos pode variar de 50.000 unidades até 500.000 unidades ano, 
neste caso para itens de grande sucesso. Como a empresa trabalha produtos populares, é possível entender que não existe a escala ou margem necessária para criar a oportunidade financeira de realizar atividades de pesquisa para algumas linhas de produto em particular. Aliado a isso, existe também a questão da empresa estar alcançando, na percepção do entrevistado, sucesso no mercado. Diante disso, os integrantes da empresa não consideram necessário realizar pesquisas para identificar os segmentos que serão atendidos.

Atualmente, a empresa tem no seu portfolio de produtos 185 itens. Desse grupo, apenas por volta de 35 ou 40 apresentam concorrentes diretos. Weinstein (1995) propõe que a opção estratégia de difusão é mais adequada para empresas monopolistas e, sendo assim, a escolha da empresa por esse tipo de estratégia parece ser acertada, tendo em vista o número de concorrentes diretos.

Embora não existam estratégias definidas para realizar o processo de segmentação conforme sugerido pela literatura, a empresa tem de forma bastante clara que seu público é de baixa renda, que busca produtos a preços populares, conforme atestam as palavras do entrevistado:

O pai entra numa loja e o moleque quer um brinquedinho. Se você toda hora colocar a mão no bolso e tirar 30 ou 40 reais não dá. Ai vai, tira 2 ou 3 [...]. É o maço de cigarro que ele deixa de comprar. Cervejinha, ao invés de tomar meia dúzia ele toma 5 e leva o brinquedinho pra criança e a criança sai satisfeita.

Com base nos comentários do entrevistado, é possível visualizar um público alvo composto por crianças em diferentes faixas etárias, oriundo das classes mais populares. As faixas etárias podem ser determinadas a partir de qual idade o brinquedo em questão é recomendado. Destarte, a empresa apresenta nos seus produtos a recomendação da faixa etária mais adequada, como, por exemplo, (1) Não recomendável para crianças entre 0 e 3 anos, (2) A partir de 2 anos e (3) A partir de 4 anos.

Com relação a questões de gênero, o entrevistado considera que os mercados são parelhos. Que não existem grandes diferenças entre produtos oferecidos para meninas e meninos. A única consideração do entrevistado sobre esse assunto sinaliza para uma percepção de que existem mais produtos para meninos do que para meninas. O diretor considera que faltam no mercado produtos mais específicos para meninas, principalmente acessórios para as bonecas. 
É interessante notar que a questão da idade não é uma decisão única e exclusiva da empresa, tendo uma grande interferência do Inmetro - Instituto Nacional de Metrologia, Normalização e Qualidade Industrial (INMETRO, 2008).

Quadro 26 - Testes Inmetro para brinquedos

\begin{tabular}{|l|l|}
\hline Teste & Explicação do objetivo do teste \\
\hline Impacto / queda & $\begin{array}{l}\text { Verifica o possível surgimento de partes pequenas e/ou cortantes, pontas agudas ou } \\
\text { algum mecanismo interno acessível a criança. }\end{array}$ \\
\hline Mordida & $\begin{array}{l}\text { Visa descobrir se o brinquedo pode gerar partes pequenas, pontas perigosas ou } \\
\text { partes cortantes quando arrancadas pela boca. }\end{array}$ \\
\hline Tração & $\begin{array}{l}\text { Verifica a possibilidade do surgimento de ponta perigosa e do risco da criança cair } \\
\text { sobre esta ponta. }\end{array}$ \\
\hline Químico & Analisa a presença de, dentre outros elementos, metais pesados nocivos à saúde \\
\hline Inflamabilidade & $\begin{array}{l}\text { Testa se o produto entra em combustão rapidamente e se o fogo se espalha pelo } \\
\text { corpo da criança, caso passe com o brinquedo perto do fogo. }\end{array}$ \\
\hline Ruído & $\begin{array}{l}\text { Verifica se o nível de ruído do brinquedo está dentro dos limites estabelecidos na } \\
\text { legislação. }\end{array}$ \\
\hline
\end{tabular}

FONTE: INMETRO; 2008.

A partir das considerações do Inmetro, a empresa recebe a autorização para comercializar o brinquedo, ou recebe a exigência de adaptar o brinquedo para atender a todos os testes realizados. Neste caso, o entrevistado dá o exemplo de uma maracá que, ao ser analisada pelo Inmetro, recebeu uma restrição no sentido de diminuir o nível ruído que o produto gerava. Neste caso em particular, a organização foi obrigada a mudar a composição do produto para que o nível de ruído diminuísse.

A partir de um estudo dos dados, é possível apresentar algumas conclusões gerais a respeito do processo de segmentação da empresa Pica Pau:

- As decisões de segmentação e seleção do público alvo são tomadas com base no feeling dos gestores da empresa, que é suportado pela experiência de mercado que eles possuem e pela observação de mercados no exterior.

- A empresa utiliza basicamente duas variáveis para determinar e compreender seu público-alvo: idade e renda. 


\subsubsection{Estratégia de posicionamento}

Novamente, lançar-se-á mão dos dois tipos de posicionamento apresentados pela literatura, o posicionamento de mercado e o posicionamento psicológico (DIMINGO, 1988), para avaliar as decisões da Pica Pau concernentes a esse tema. Portanto, esta etapa da análise do caso Pica Pau é dividida em duas partes, cabendo salientar que, apesar desta diferenciação originada do desejo de tornar a análise mais clara, os dois processos devem ser conduzidos pela empresa de forma conjunta (TOLEDO e HEMZO, 1991).

\subsubsection{Estratégia de posicionamento de mercado}

A análise do posicionamento de mercado da empresa está fundamentada na análise da movimentação das marcas da empresa no mapa perceptual do consumidor, assim como na comunicação das vantagens competitivas da empresa (TOLEDO e HEMZO, 1991). Além disso, presume-se que a empresa deveria realizar um planejamento estratégico adequado para a idealização das ações pretendidas (ACHENBAUN, 1974). A Pica Pau não realiza nenhum dessas atividades de forma organizada. A empresa toma as decisões referentes ao seu posicionamento de mercado da mesma forma como realiza o processo de segmentação, ou seja, por meio do feeling dos gestores da empresa. Apesar disso, a empresa analisa o mercado e toma suas decisões, mesmo que de forma não estruturada. Por exemplo, o entrevistado reconhece que a entrada de produtos chineses no mercado causou uma série de problemas concorrenciais para a empresa:

A influência da indústria chinesa no mercado brasileiro foi fatal para nós. Teve uma influência decisiva. Você diminuiu inclusive o número de empresas de brinquedos no pais. Nós não conseguimos concorrer com eles [...] no quesito custo final.

As palavras do entrevistado sinalizam para o impacto causado pela entrada dos produtos chineses no mercado. $\mathrm{O}$ diretor relaciona essa capacidade da indústria daquele país em conseguir preços inferiores à mão de obra barata que as fábricas têm acesso. Ressalta ainda o diretor que, apesar do produto chinês ter um custo inferior, esse custo reduzido corresponde às versões mais básicas dos produtos oferecidos: "você tem o mesmo item com quatro ou cinco tipos de qualidade diferente lá. Então depende muito do que você traz. Onde você compra, né?”. 
O entrevistado percebe que a influência dos produtos orientais no mercado diminuiu muito, pois os consumidores começaram a perceber que a qualidade dos produtos oferecidos por preços muito baixos era também muito baixa:

A partir daí o consumidor começou a olhar também - Peraí, eu comprei barato, mas só que eu dei para minha filha e durou dois minutos. Acabou. - A alegria de uma hora e depois é fim de feira. Acabou. Até agora diminuiu um pouco a incidência. $\mathrm{O}$ volume continua grande de entrada de produtos, mas a influência sobre nós aqui da Pica Pau diminuiu muito.

Afora a competição chinesa, que não tem mais o efeito anterior, a empresa enfrenta competidores para uma pequena parcela dos seus produtos (entre 35 ou 40 dentre os 185 itens sendo produzidos). Essa consideração feita pelo diretor transparece uma tranqüilidade com relação ao impacto de outros concorrentes.

As afirmações do entrevistado sinalizam que a empresa procura compreender a dinâmica do mercado para poder competir de forma mais adequada, seguindo as sugestões de DiMingo (1981) e Toledo e Hemzo (1991). Apesar dessa tentativa, percebe-se que a falta de um processo mais estruturado de análise do mercado (empresa e concorrentes) torna a análise da empresa com relação ao seu posicionamento de mercado bastante superficial. Por exemplo, ao considerar que apenas 35 ou 40 dos seus produtos têm concorrentes o entrevistado deixa de compreender que é possível que o consumidor adentre o ponto de venda e selecione o brinquedo que irá comprar de diferentes categorias de produtos, aumentando assim a abrangência da concorrência que cada uma das linhas de produto da empresa enfrenta.

A empresa também indica ter um foco bastante concentrado no mercado popular, conforme indica o entrevistado: "[a] gente trabalha os produtos pra se adaptar a um mercado que a gente já conhece. A gente não pretende entrar em outro mercado”. Isso significa que a empresa não almeja competir com empresas como a Mattel, que tem capacidade de investimentos muito superior tanto no desenvolvimento do produto como nos esforços de comunicação. Ao ser questionado sobre uma possível entrada em segmentos de qualidade superior, o informante foi bastante enfático ao afirmar que: 
Não. Não vale o investimento. Eu acho que não. A nossa filosofia aqui na Pica-Pau, não é demagogia não, a gente está se dando muito bem nesse mercado (popular). Se for mudar de mercado eu vou mudar o perfil da empresa. E mudar o perfil da empresa não é interessante.

Apesar de ter esse foco no mercado popular, a empresa tem trabalhado alguns produtos com um ligeiro valor agregado, tendo em vista o desejo de colocar seus produtos em redes de brinquedos como a Rihappy, afinal essa rede possui aproximadamente 80 lojas, representando um mercado interessante para a empresa. A rede Rihappy foi uma das marcas mais lembradas por crianças de alta renda pesquisadas por Veloso e Hildebrand (2007), caracterizando-a como uma rede com forte apelo junto ao público infantil de alta renda. Percebe-se então que existe uma mudança clara nas estratégias da Pica Pau.

O entrevistado faz questão de salientar que determinados produtos da sua linha não são adequados ao público da Rihappy e, por isso, está desenvolvendo alguns produtos que poderiam ser colocados neste tipo de loja que tem um público diferenciado daquele que a empresa está acostumada a atender. Essas considerações podem ser extraídas do trecho apresentado a seguir:

O que a gente fez aqui no sentido de ter produtos com valor agregado um pouquinho mais alto, é exatamente pra que a gente tenha um pouquinho de chance de entrar em alguns clientes que são mais especializados, como loja de shopping que eu não entrava antes. Eu trabalhava só com o popularzão. Hoje a gente já entra, mas também entra assim, maneiro. Nada de querer lançar produtos de alto custo, não só de custo de produção, mas de custo final também.

Durante esse processo de introdução de produtos voltados para crianças no segmento denominado pelo entrevistado como primeira infância, a empresa procura obter o apoio de pedagogos e psicólogos para garantir que o produto seja realmente adequado para esse segmento de mercado. Esses consultores trabalham analisando qual a influência que o produto pode ter sobre a criança e que tipo de material pode ser utilizado.

Ao fazer essa transição para redes mais destacadas, a empresa tem enfrentado dificuldades, principalmente na rede Alô Bebê. Essa rede, reconhecida pela oferta de produtos para crianças, tem colocado algumas restrições para a entrada da Pica Pau no seu sortimento de produtos. A Alô Bebê afirma que a empresa ainda não tem um sortimento de produtos grande o bastante para fazer parte dos fornecedores da empresa. Segundo o entrevistado, isso não the parece correto, pois ele teria a capacidade de apresentar produtos muito mais baratos do que os importados 
oferecidos pela Alô Bebê. É possível compreender que a Alô Bebê não tem interesse em inserir brinquedos mais baratos, os quais iriam concorrer diretamente com os importados que geram uma alta margem para a empresa. Essa tentativa estratégica da empresa está fundamentada numa vantagem competitiva que ela possue frente aos produtos importados, que é a diferenciação por custo. Esse tipo de iniciativa é recomendado por Doyle e Saunders (1985), os quais consideram que a empresa somente irá competir efetivamente se basear essa competição em vantagens que não podem ser facilmente copiadas pelos concorrentes.

Ao fazer essa transição, tentando oferecer produtos mais baratos para outros segmentos de mercado, a empresa está na realidade transferindo uma vantagem competitiva que possui para outros mercados. Essa vantagem pode ser compreendida por meio das colocações de Porter (1986), ou seja, a empresa está colocando em prática a estratégia denominada pelo autor como diferenciação por baixo custo.

De acordo com Chernatony et al. (1993), é responsabilidade do gestor encontrar alternativas de posicionamento que alinhem as forças da empresa com as oportunidades de mercado. Essa disposição pode ser percebida quando o diretor salienta que seus produtos têm um preço bastante inferior aos produtos importados oferecidos pela Alô Bebê. Partindo disso, a empresa está direcionando seus recursos para conseguir entrar nesse mercado, conforme sugerem Hassan e Craft (2005). Na nomenclatura utilizada por Blankson e Kalafatis (2004), a estratégia da empresa seria denominada Valor por Dinheiro, ou seja, a empresa cobra um preço razoável por um produto com determinado nível de qualidade. Essa estratégia que está sendo desenvolvida é claramente uma oportunidade de mercado, conforme conceituada por Toledo e Hemzo (1991).

Resumidamente, é possível apresentar algumas conclusões gerais sobre a questão do posicionamento de mercado da empresa:

- A empresa não realiza nenhum processo estruturado de planejamento, baseando suas decisões no feeling dos gestores. 
- A empresa acredita que apenas uma pequena parcela dos seus produtos enfrenta concorrentes diretos, e que isso faz com que a empresa não tenha muitos problemas com a concorrência.

- A empresa está focada no segmento popular, mas está passando por um processo de aumento do valor oferecido nos seus produtos. Essa estratégia visa fazer parte do sortimento de varejistas mais renomados, como Rihappy e Alo Bebê.

\subsubsection{Estratégia de posicionamento psicológico}

DiMingo (1989) define o posicionamento psicológico como o esforço de criação de uma determinada imagem, para então trabalhar as ferramentas de comunicação para transmitir esse posicionamento. Aaker (1998) esclarece a diferença entre imagem da marca e posicionamento, indicando que o posicionamento é mais abrangente, pois leva em consideração as ações da concorrência. A imagem de uma marca, por sua vez, é construída não só pelos esforços de comunicação, mas também pelos outros elementos do composto de marketing, como preço, atributos do produto, classe do produto, usos e aplicações, entre outros. Hooley e Saunders (1996) trazem a idéia de que não basta para a organização criar e comunicar uma imagem, mas esse significante deve transparecer nos outros elementos do mix de marketing, transformando o que eles chamaram de declaração de intenção em realidade. Diante destas considerações, faz-se necessário analisar não somente a questão da comunicação e o posicionamento, mas também a interferência das outras variáveis de marketing na criação do posicionamento desejado. Dessa forma, esta etapa do trabalho abordará todas as iniciativas da empresa com relação ao composto de marketing (preço, praça, produto e é claro promoção).

\subsection{Estratégia de posicionamento psicológico - produto}

A empresa indica que tem como lema de trabalho "[s]empre ter uma novidade", isso é patente nas informações contidas no próprio site da empresa, onde são apresentados os lançamentos do ano (9 diferentes linhas de produtos):

- Linha Fantasia

- Linha Meninos

- Linha Meninas 
- Linha Carimbos Educativos

- Linha Primeiros Passos

- Linha Móbile

- Linha Chocalhos Soft

- Jardinagem \& Praia

- Linha Ação

O entrevistado esclarece que a empresa não possui uma área específica para a criação de novos produtos. Esse processo é conduzido de uma maneira até informal, por meio de reuniões periódicas entre o próprio entrevistado e o Sr. Eduardo (proprietário-fundador da empresa). Essas reuniões são fundamentadas em viagens que o Sr. Eduardo realiza, buscando identificar as tendências futuras do mercado. Percebe-se aqui uma clara escolha da empresa por uma estratégia de desenvolvimento de produtos que apresentam menores riscos financeiros, mas que também têm menores chances de ser um grande sucesso (MCNEAL, 1992). As considerações de McNeal (1992) fundamentam-se na idéia de que ao copiar um produto já existente os riscos são menores, o que não ocorre no desenvolvimento de produtos realmente inovadores.

As viagens realizadas pelo fundador da empresa, com a intenção de analisar o mercado europeu/norte-americano, podem ser encaradas como uma forma de compreensão do desenvolvimento futuro do mercado brasileiro. A premissa adotada pelos integrantes da empresa é que, se deu certo na Europa ou nos Estados Unidos, pode ser que funcione no Brasil. O diretor relata que o fundador e presidente da empresa coleta inúmeras idéias de novos produtos quando faz essas viagens, mas que de cada 5 idéias apenas uma acaba sendo concretizada. A experiência de mercado dos gestores da empresa serve como fundamento para decidir qual idéia pode ser adaptada para o consumidor nacional.

Em alguns casos, a empresa trabalha produtos com uma inspiração em temas nacionais, como itens relacionados à Copa do Mundo de Futebol, ao Carnaval e à praia. Mas mesmo nesses casos, os produtos são apenas adaptados, como no caso da Copa, quando alguns produtos mudam de cor. Afora esses casos, os produtos não abordam temáticas nacionais e folclóricos, como o caso dos personagens Saci-Pererê e o Curupira. 
Outra forma de trabalhar a introdução de novos produtos é o uso de licenças para agregar personagens de sucesso aos produtos da empresa. Dados oferecidos pela ABRAL - Associação Brasileira de Licenciamento (2008) indicam que existem 80 agências licenciadoras, que disponibilizam aproximadamente 550 licenças para 900 empresas. Essas iniciativas de licenciamento, quando advém de filmes, seriados e desenhos que fazem sucesso entre o público infantil, são, na grande maioria dos casos, oriundas de produção estrangeiras. Como parte do desejo das crianças por produtos é direcionada pela presença de personagens (MONTIGNEAUX, 2003; ACUFF e REIHER, 1997), é até natural que um seriado ou filme que faça sucesso na Europa, tenha um nível similar de sucesso no Brasil.

O entrevistado vê a questão do licenciamento como uma estratégia interessante para as empresas, mas carregada de riscos e altos custos:

O Shrek, o próprio Power Rangers, então tem aquele período de boom de vendas e depois ele vai embora. Ai ele entra num marasmo tão grande que quem licencia esse produto nem mantém na linha porque não dá. Não dá para você pagar uma fortuna pra licenciar.

Licenciamento é interessante, mas também é aquela história você corre aquele risco. Você lançou hoje o Cocoricó, que está na crista da onda, daqui a pouco ele vai cair, despenca. E você fica com todo o investimento aqui. Então essas coisas que você tem que estar atento para não tropeçar.

Percebe-se nas próprias palavras do entrevistado, que o licenciamento geralmente está fundamentado em personagens (de filmes, desenhos ou seriados) que apresentam um sucesso momentâneo, fato que deve ser aproveitado rapidamente. Caso isso não seja feito na velocidade necessária, corre-se o risco de ter uma enorme quantidade encalhada nos estoques em função do final do modismo/moda. Esse risco é percebido pelo entrevistado como ainda mais complicado no momento em que se consideram investimentos com desenvolvimento, molde, produção e lançamento do produto. Todo o custo e o risco desse processo recaem sobre o fabricante, que, em muitos casos, é obrigado a pagar antecipadamente uma jóia, ou seja, um percentual sobre um número mínimo de peças vendidas. O informante esclarece que esse percentual pode ou não se concretizar futuramente no mercado, mas o fabricante é obrigado por contrato a pagar esse valor antecipadamente. 
O diretor também salienta a questão do custo, o qual é ainda mais complicado para as características da empresa - voltada para os segmentos mais populares. Esse custo, oriundo do pagamento de royalties, gira em torno de $8 \%$ a $12 \%$ do preço de venda ao atacado. O entrevistado percebe que esse custo acaba recaindo, sob forma de cascata, sobre o consumidor final, o que atrapalha o posicionamento da empresa.

O informante finaliza suas considerações apresentando as dificuldades que podem existir para conseguir obter a permissão para determinado licenciamento que está sendo disputado no mercado. Ele cita o exemplo de produtos da Turma da Mônica. Naquele momento, o diretor teve inúmeros pedidos de licenciamento recusados porque outras empresas já estariam lançando produtos similares. Como a Pica Pau trabalha com produtos populares de baixo preço, existe a possibilidade de ser mais interessante para o licenciador conceder permissão para uma empresa que trabalhe produtos de maior valor agregado e, por conseguinte, com maiores margens.

Como forma de contornar essas questões de licenciamento, percebe-se que a empresa opta por desenvolver e criar produtos que são inspirados em personagens de sucesso, conforme pode ser visto na Ilustração 25 , onde os bonecos representam apromixações dos seguintes personagens: Power Rangers, Rambo, Zorro e Darth Vader.

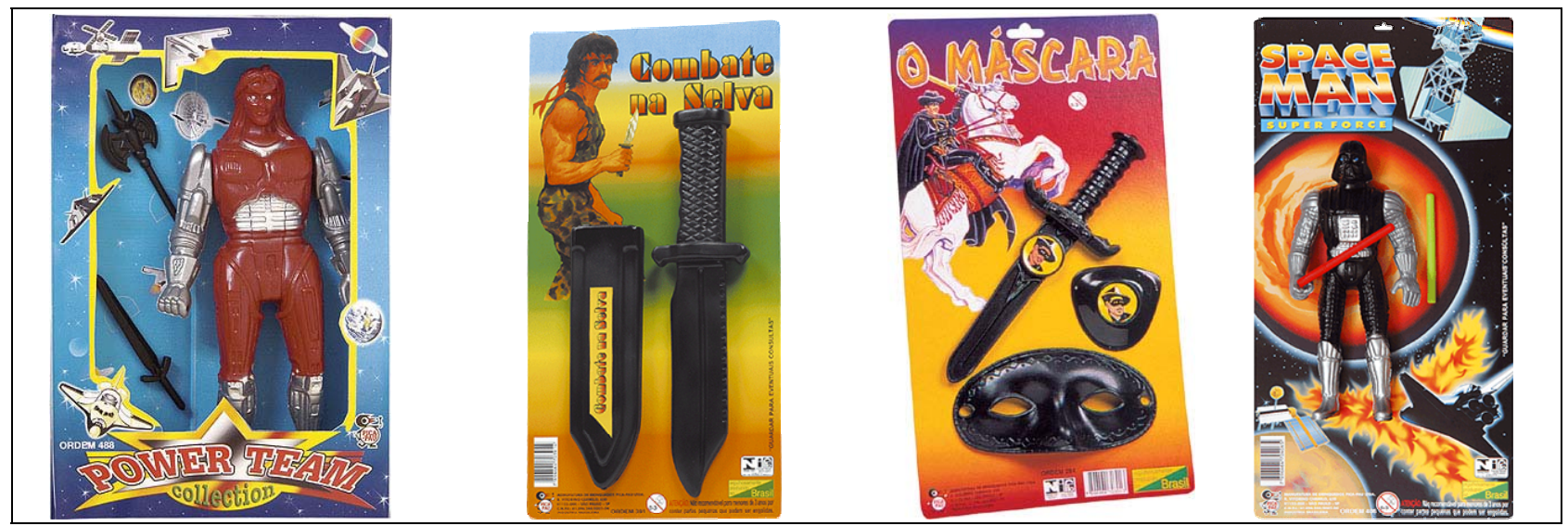

Ilustração 25 - Adaptações de personagens famosos FONTE: PICA PAU; 2008.

Ao desenvolver esses produtos inspirados em personagens de sucesso a empresa reconhece a importância de atentar para os centros de interesse da criança, o que está em consonância com as idéias de Montigneaux (2003). O autor trata de forma aprofundada a questão dos personagens no 
imaginário infantil, indicando o potencial de sucesso de produtos que fazem uso deste tipo de estratégia, mesmo na forma de imitação como faz a Pica Pau.

O processo de desenvolvimento do produto é realizado com antecedência de até 1 ano, haja vista que o processo de definição do produto a ser lançado, da elaboração de um protótipo, testes do Inmetro e produção do molde toma um tempo considerável, esclarece o entrevistado.

Tratando especificamente dos testes do Inmetro, o funcionário da Pica Pau esclarece que são feitos testes internos para assegurar que o produto atenda todos os requisitos necessários. É objetivo da organização enviar o produto para teste no Inmetro e receber a autorização para a comercialização, sem que haja retrabalho na elaboração do produto. Essa preocupação da empresa com a qualidade do brinquedo também é explicada pela preocupação dos gestores da empresa em lançar produtos seguros para um público ainda em desenvolvimento, que não tem a capacidade de perceber algum risco no momento do uso e consumo.

O diretor informa que são realizados alguns testes para certificar que o produto terá aceitação no mercado e para perceber questões relacionadas à durabilidade do produto na mão das crianças. Esses testes têm uma característica um tanto amadora, conforme pode ser percebido por suas palavras:

Tipo um teste de campo, né? A gente eventualmente faz isso também. A gente faz um laboratório. A gente produz algumas peças e você deixa isso na mão de algumas crianças. Até para entender e conhecer qual a durabilidade. Que a criança é a criança. Se você falar ele tomar cuidado ele vai tomar cuidado. Se você soltar na mão dele e falar brinca. Ai ele vai fazer tudo o que deve e não deve. Então você entende também quais os problemas que você vai ter posteriormente.

Essa preocupação com a qualidade do produto também transparece na idéia de que o consumidor não pode sofrer qualquer tipo de descontentamento com o produto, pois isso pode gerar uma percepção negativa da empresa e dos demais itens de seu portfolio. Essa apreensão pode ser ainda maior tendo em vista o público alvo que a empresa atende, o qual não teria recursos financeiros para desperdiçar na compra de um produto. 
Uma vez lançado o produto, a Pica Pau tem um prazo de 6 ou 7 meses para verificar se o produto está tendo o desempenho esperado quanto às vendas. Caso isso não aconteça, a empresa diz que é preferível tirar o produto do mercado. Uma das primeiras percepções sobre as perspectivas do produto no mercado é oriunda das opiniões dos varejistas. De acordo com o entrevistado,

Se o teu cliente, o lojista no nosso caso, ele se encantou com o produto, a probabilidade desse produto lá na ponta ser um sucesso é muito grande. Se o teu cliente, lojista, torcer o nariz, ai você já pode medir um pouquinho o que pode acontecer no mercado. Pode haver inversões.

A empresa reconhece que o consumidor infantil está passando por um processo de mudança, que a criança atualmente está cada vez mais ligada a questões tecnológicas, por exemplo o uso de computadores por crianças de 5 ou 6 anos. O informante esclarece que este não é seu públicoalvo, mas tece algumas considerações referentes a sua preocupação com a formação das crianças nesse novo ambiente. Para ele, o indivíduo está perdendo um pouco da chamada infância, ou seja, está deixando de lado brincadeiras tradicionais que trabalhavam o lado lúdico e a fantasia, fato que talvez explique o foco da empresa em produtos que ainda têm características que permitam a fantasia e o brincar em grupo.

Cabe ressaltar que mesmo com essas mudanças, ainda existem produtos que ficam na linha de produção por um período bastante longo. O entrevistado cita dois exemplos, um que já está a 10 anos no mercado e outro que está no mercado há 12 anos (jogo de bilhar).

Com relação à questão da embalagem, o entrevistado considera que as crianças não vão à loja buscar um produto da empresa Pica Pau, mas sim atrás de um brinquedo e, por isso, a empresa desenvolve embalagens que deixam o produto totalmente a mostra para avaliação dos consumidores.

Conforme colocado anteriormente, grande parte dos produtos introduzidos pela empresa trabalha a questão da fantasia, permitindo que o infante utilize sua imaginação e pretenda ser outro, esse tipo de produto é normalmente desejado por crianças entre 3 e 7 anos (ACUFF e REIHER, 1997) (para exemplos ver Ilustração 25). Além disso, a empresa também trabalha a questão do lançamento de produtos que os pais imaginam que seus filhos necessitem, que são direcionados para crianças até 2 anos (ACUFF e REIHER, 1997). Esses produtos são direcionados para uma 
tentativa dos pais em incentivar o desenvolvimento da criança, conforme esclarecem Acuff e Reiher (1997). As escolhas da empresa com relação ao apelo dos produtos lançados está de acordo com as sugestões da literatura sobre a adequação de cada apelo e a sua faixa etária correspondente.

A partir das considerações apresentadas é possível resumir os principais resultados nos itens apresentados a seguir:

- Com relação ao processo de desenvolvimento de produto percebe-se que a empresa opta pela adaptação de produtos já existentes em outros mercados, não desenvolvendo produtos realmente inovadores.

- Ademais, é possível compreender que existe uma preocupação com a qualidade do produto para não gerar decepções junto ao seu mercado. A empresa trabalha a ligação das crianças com personagens famosos lançando produtos inspirados em personagens variados.

- A empresa atenta para o nível de desenvolvimento do seu público-alvo no momento do desenvolvimento do produto, procurando não oferecer nenhum tipo de risco para seus consumidores.

\subsection{Estratégia de posicionamento psicológico - preço}

O funcionário da Pica Pau considera que a empresa está focada no mercado popular e, assim, os produtos estão precificados até um teto de 14 reais. Essa faixa de preços torna as ofertas da empresa acessíveis para um público bastante grande. Essa capacidade de oferecer um item a preços tão baixos é decorrente dos esforços da empresa no sentido de trazer para o segmento popular a capacidade de compra, indica o entrevistado.

Somando às colocações anteriores, o informante apresenta a estratégia de elaboração do preço do produto, esclarecendo que a empresa determina um preço alvo e um respectivo custo alvo, que é decorrente de uma análise do mercado e de uma decisão da empresa sobre a oferta que está em discussão. 
Bom, mas se eu preciso lançar isso aqui eu preciso chegar até o preço. Lá na ponta. Eu vou trabalhar pra poder ter condição do consumidor pagar esse preço que eu estimei. Se eu não conseguir abandono o projeto e vou pra outro.

Enfatiza-se que essa avaliação e tomada de decisão é realizada pelo proprietário da empresa e pelo gerente de vendas, a partir do feeling, sem nenhum apoio de esforços de pesquisa de mercado. Desta forma, a estratégia denominada por Nagle e Holden (2005) como sendo de apreçamento baseado no valor não se realiza plenamente, pois a percepção do valor que o consumidor está propenso a pagar pelo produto está fundamentada nas avaliações dos gestores.

Abaixo seguem as principais considerações deste tópico:

- A empresa tem um processo de determinação de preço que começa com a identificação de um preço-alvo em consonância com as necessidades do públicoalvo.

- A empresa tenta compreender as percepções de preço dos consumidores, mas de forma não estruturada.

- De forma geral os preços são baixos, focados na aceitação junto ao público mais popular.

\subsection{Estratégia de posicionamento psicológico - praça}

Ao estabelecer como público alvo um segmento popular, conforme denominação do entrevistado, torna-se necessário criar um sistema de distribuição que faça com que o brinquedo chegue até o consumidor. Esse esforço é conduzido pela empresa por meio de representantes. A empresa tem trinta e nove (39) representantes, sendo que do total, cinco (5) estão locados na Grande São Paulo. Esses intermediários são responsáveis por entrar em contato com pequenos varejistas que trabalham com as categorias de produto pertencentes ao portfolio da Pica Pau. Os representantes visitam não só as lojas das capitais estaduais, mas também pequenas cidades do interior, fazendo um trabalho árduo de contato, apresentação dos produtos e vendas. $O$ entrevistado reconhece que a cobertura conseguida pela empresa ainda não é a adequada, pois existem locais onde os representantes não conseguem realizar os contatos de venda. 
Uma vez vendido o brinquedo, chega o momento de entregar o mesmo para os varejistas. Após a realização do pedido, é terceirizado o esforço de entrega para empresas de transporte. O informante dá o exemplo de uma venda para a cidade de Belém do Pará. O processo é demorado, pois as transportadoras necessitam de tempo para encher o caminhão e partir para a entrega. $\mathrm{O}$ entrevistado estima que são necessários cerca de 15 dias para finalzar todo esse processo.

A questão da distribuição se torna ainda mais importante quando da chegada de datas especificas, como o dia da criança e o natal, que são as datas mais importantes para as empresas de brinquedos, sendo o natal a data mais importante no ano (segundo o entrevistado). Além dessas datas, o diretor também ressalta a feira de brinquedos organizada pela Abrinq em Abril de cada ano como ponto fundamental para o desempenho da empresa ao longo do ano. Nesse evento, são feitos os grandes lançamentos de produtos do ano. A empresa vai para essa feira com todo o seu cronograma de lançamentos já estabelecidos, outras empresas usam a feira como um termômetro para avaliar quais produtos devem realmente ser lançados.

Os varejistas que os distribuidores atendem são aqueles que trabalham junto a segmentos mais populares, como a Issam (localizada no Pari) e Armarinhos Fernando, uma das lojas mais populares do maior centro de compras das camadas populares, a 25 de março, conclui o entrevistado. Nessas lojas, os consumidores compram os produtos em grandes quantidades, com o objetivo de revendê-los em outros locais. Ponto de venda também importante para a empresa, agora no segmento com um valor maior agregado, é o composto pela rede de brinquedos Rihappy.

O informante reconhece que a empresa tem uma predileção por empresas focadas no ramo de brinquedos, salientando que outros potenciais varejistas que poderiam carregar os produtos da empresa são os supermercados, mas por estes não terem o brinquedo como preocupação principal, acabam não recebendo a mesma atenção da Pica Pau. Nos supermercados, a empresa entende que a Mattel é uma das empresas mais agressivas, trabalhando para comprar espaço nas gôndolas, o que não acontece com as outras empresas de brinquedos, que não aceitam esse tipo de prática. 
A empresa transparece uma grande preocupação com o relacionamento com os seus distribuidores, principalmente quando acontecem encalhes. Esclarece o informante, no entanto, que nestes casos a solução encontrada é a troca dos produtos que não estão girando bem naquele determinado varejista. Esses produtos são então redirecionados para varejistas em outras regiões. Isso acontece porque, em alguns casos, um produto que está parado na gôndola em determinada região, está saindo bem em outra.

Abaixo são apresentadas as principais considerações sobre a estratégia da Pica Pau:

- O foco da empresa é nos varejistas que trabalham atendendo o segmento popular (p.ex.: Issan e Armarinhos Fernando), principalmente por meio de promotores.

- A empresa também está trabalhando a entrada em varejistas que trabalham segmentos que procuram produtos mais diferenciados (p.ex.: Rihappy e Alô Bebê).

- O varejo supermercadista não recebe o mesmo nível de atenção por não estar focado no segmento de brinquedos.

\subsection{Estratégia de posicionamento psicológico - promoção}

Apesar de Aaker (1998) relacionar o posicionamento psicológico com a imagem de marca da empresa, o entrevistado coloca que a empresa não faz questão de trabalhar de forma significativa sua marca: "o logo aparece discretamente, não há nenhuma preocupação ainda com pegar o logo e deixar ele como parte principal da apresentação do produto". A Pica Pau considera que já tem certo reconhecimento no mercado e que a necessidade de construção da imagem é preocupação de empresas que trabalham produtos com um maior valor agregado, como por exemplo, a Mattel.

\footnotetext{
O Pica-Pau, queira ou não, é um nome mais conhecido, então a logomarca ainda fica como uma lembrança, ai não como foco principal. O foco principal é o produto. [...]. A situação inverte. Você vende Mattel para depois vender o produto. No nosso caso a gente vende o produto pra depois vender Pica-Pau.
}

Em função dessas considerações, a organização foca seus esforços na apresentação do produto, por isso todas as embalagens da empresa deixam o produto totalmente a mostra, para criar um apelo junto às crianças. Acuff e Reiher (1997) destacam que crianças entre 3 e 7 anos não estão 
preocupadas com o que está escrito na embalagem, focando mais no apelo visual do pacote. Dessa forma, parece acertada a opção da empresa em deixar o produto totalmente à mostra.

Os esforços de comunicação da empresa estão focados basicamente no preço e no boca-a-boca. O entrevistado acredita que o baixo preço dos produtos colocados no mercado já é o atrativo necessário para atrair consumidores da camada popular. Já a qualidade dos produtos, aliada ao preço baixo, seria responsável por criar o boca-a-boca positivo dos produtos da empresa. A preocupação com este fenômeno é demonstrada quando a empresa sinaliza um grande esforço despendido no desenvolvimento de produtos que não geram decepção nos consumidores. Essa idéia pode ser mais bem compreendida nas palavras do próprio entrevistado:

Depois de comprado ele não pode gerar nenhuma, nenhum tipo de incerteza, nenhum tipo de insatisfação. Não tem coisa mais triste do que uma criança comprar um brinquedo desses e por alguma razão ele não consegue brincar. É decepcionante, é frustrante, então você tem que trabalhar de forma a não provocar esse tipo de frustração. Porque ai sim entra a história da marca. De quem é esse brinquedo? É da Pica-Pau? Então da Pica-Pau eu não compro mais.

Os únicos esforços de comunicação que a empresa faz são aqueles relacionados à promoção de ofertas em alguns tablóides e na mídia impressa destinada ao canal distribuidor. A fábrica de brinquedos coloca anúncios esporádicos em revistas direcionadas ao canal de distribuição. Essas iniciativas são promovidas a cada três meses em revistas especificas do ramo, como nas revistas Brinquedo e Brincar.

O entrevistado acredita que o esforço máximo da empresa deve ser para colocar o produto na gôndola, pois “o produto na área de venda se vende”. Essa preocupação com o ponto de venda é percebida também nos esforços da empresa em colocar promotores em algumas lojas para garantir a correta exposição do produto. Esses promotores estão presentes em 22 lojas da Rihappy, em 10 lojas Armarinhos Fernado e em outros 48 pontos de venda, aproximadamente.

A empresa reconhece que, se houvessem esforços maiores de comunicação com o consumidor, as vendas seriam maiores. $\mathrm{O}$ informante oferece um exemplo, dizendo que um brinquedo que vende 50.000 unidades, mas que poderia vender até 120.000 unidades caso fosse suportado por esforços 
de comunicação, como mídia e merchandising. Assim mesmo, a empresa prefere focar seus esforços de comunicação para o canal de distribuição.

Como forma de contato direto com o consumidor, a empresa trabalha basicamente o site e o email como forma de contato. $\mathrm{O}$ entrevistado relata que são poucos os contatos realizados por consumidores. Esses poucos contatos geralmente se relacionam com produtos que o consumidor considerou como defeituoso. A resposta da empresa para este tipo de ocorrência é a troca do produto sem maiores discussões. O entrevistado explica essa estratégia da seguinte forma:

Então troca e liquida a fatura que é mais tranqüilo. É mais sensato. O consumidor final é o nosso propagandista no caso da Pica-Pau. Então eu não quero que ele saia e fale pro vizinho - Comprei lá o Brinq-Brinq da Pica-Pau, ai veio rachado um dos aros e ninguém trocou, não deu bola, não - aqui não, a gente troca tudo.

A partir do que foi apresentado, elaboram-se abaixo algumas considerações gerais sobre as estratégias promocionais da Pica Pau:

- A comunicação da empresa está focada no canal de distribuição.

- Não existem esforços de comunicação com o consumidor, ou com seus pais.

- A empresa disponibiliza um site que apresenta os produtos da empresa e fornece um email para um contato maior.

- A empresa fundamenta sua comunicação na expectativa de que ocorra o bocaaboca positivo de seus produtos.

- Esporadicamente são inseridas propagandas em revistas direcionadas ao canal distribuidor.

\subsubsection{Resumo da análise da Pica Pau Brinquedos}

A partir da análise oferecida nos tópicos anteriores foi desenvolvido um esquema representativo das atividades da empresa (Ilustração 26). Para este esquema tomou-se como base a Ilustração 15. A referida ilustração foi desenvolvida como uma forma de apresentação resumida do processo de segmentação e posicionamento. Ao reproduzir essa ilustração, adaptando-a às atividades da Pica Pau espera-se tornar mais fácil o entendimento do processo de segmentação e 
posicionamento adotado. A apresentação desta ilustração finaliza o tópico referente ao caso da Brinquedos Pica Pau, procedendo-se então para o Caso da empresa Grow Jogos e Brinquedos Ltda.

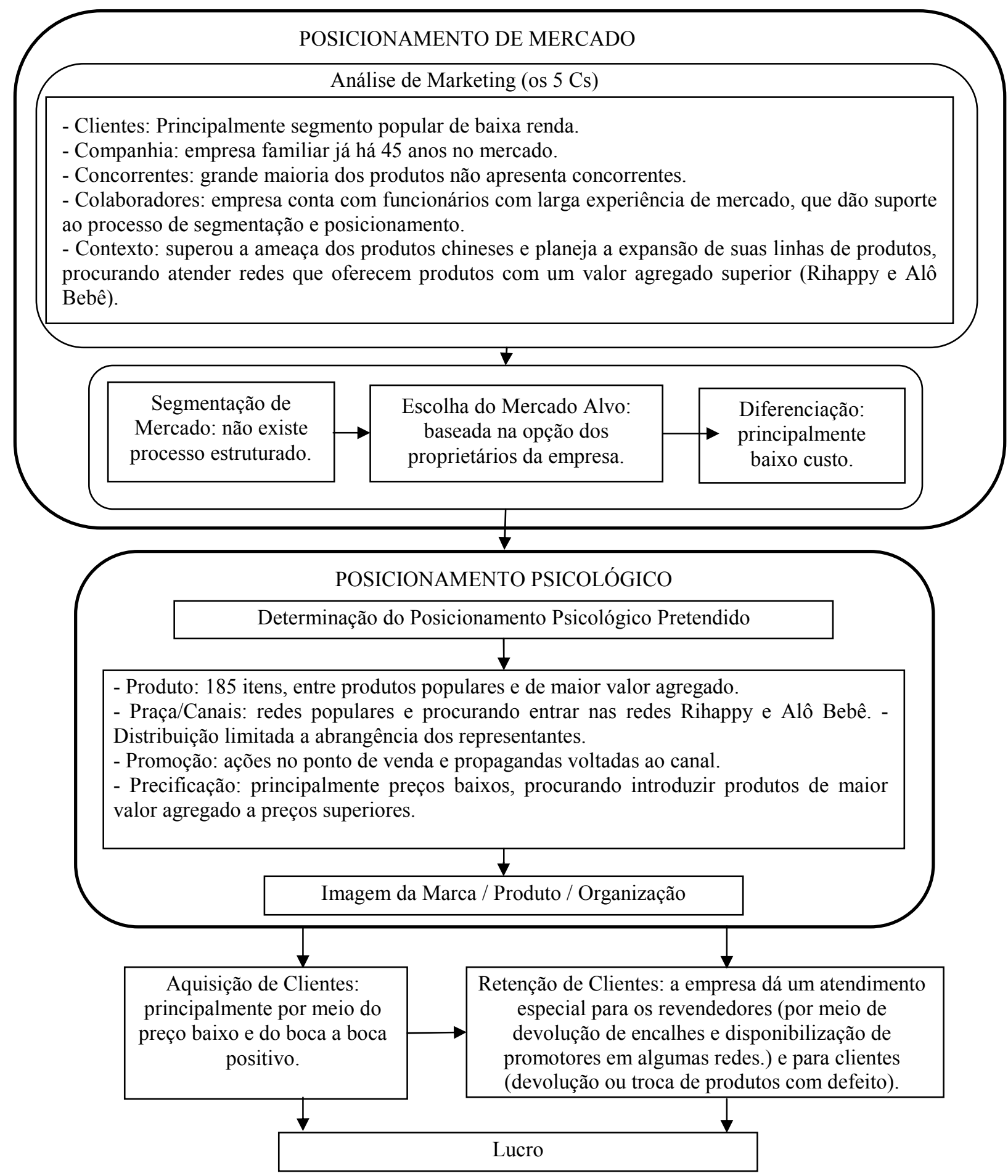

Ilustração 26 - Processo de segmentação e posicionamento da Pica Pau Fonte: Coleta de dados. 


\subsection{Caso 2 - Grow Jogos e Brinquedos LTDA}

De acordo com Grow (2008), a empresa Grow Jogos e Brinquedos Ltda foi fundada em 1973 por 4 ex-alunos da Poli-USP. A empresa teve como seu primeiro lançamento o jogo War, o qual foi seguido pelo lançamento do jogo Diplomacia. Partindo do grande sucesso destes jogos, a empresa passou a desenvolver seu portifolio de produtos para um número cada vez maior de segmentos, expandindo a atuação da empresa.

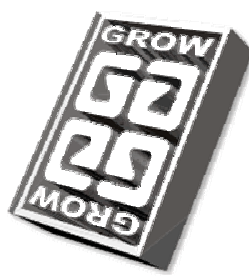

Ilustração 27 - Logotipo da empresa Grow Jogos e Brinquedos Ltda. FONTE: GROW; 2008.

A partir da década de 80 a empresa passa a oferecer novas linhas de produtos, "abrindo segmentos no mercado de acordo com "os pedidos" dos consumidores" (GROW, 2008). Atualmente a empresa trabalha com as seguintes linhas de produtos:

- Atividades: mágicas e atividades

- Baby: Baby, Brinca Madeira, Fofi-Blocs e KidBlocs.

- Brinquedos: Battle Cars, Bonecos e Bonecas e Pelúcia.

- Jogos: Jogos Adultos, Jogos de Ação, Jogos de Memória, Jogos Infantis - Apoio Didático, Jogos Infantis - Divertir, Jogos para a Família e Super Trunfo.

- Personagens: Carros Disney, Disney, Garfield, Hannah Montana, Hello Kitty. High School Musical, Homem de Ferro (Iron Man), Jump in, Littlest Pet Shop, Marvel Heroes, My Little Pony, Narnia, O Incrível Hulk, Os Vegetais, Piratas do Caribe, Pooh, Power Rangers, Princesas, Pucca, SBT, Shrek, Sítio do Picapau Amarelo, Speed Racer, Spider Man, Toy Story, Transformers, Turma da Mônica e Wall-E.

- Pré-escolar: pré-escolar. 
- Puzzles: Acessórios, Progressivo 16/25/49 Peças, Puzzle 30 Peças, Puzzle 60 Peças, Puzzle 100 Peças, Puzzle 150 Peças, Puzzle 250 Peças, Puzzle 500 Peças, Puzzle 1000 Peças, Puzzle 1500 Peças, Puzzle 2000 Peças, Puzzle 3000 Peças e Puzzle 5000 Peças.

Foi durante a década de 80 que a empresa passou a trabalhar o uso de personagens nos seus produtos, inicialmente com personagens Disney (GROW, 2008). Ao se analisar a linha de produtos da empresa percebe-se que esta é uma estratégia que passou a ser amplamente adotada. Atualmente, a empresa tem uma linha de produtos composta por aproximadamente 300 itens.

\subsubsection{Estratégia de segmentação}

O entrevistado, ao ser questionado sobre os esforços de pesquisa realizados, afirma que a empresa não tem conduzido pesquisas de qualquer tipo há algum tempo. Cabe neste momento colocar as próprias palavras do entrevistado para explicar as razões para esta decisão:

Olha, pesquisa nós não fazemos, nós não contratamos nenhum tipo de pesquisa. Já há muito tempo que nós não fazemos isso. [...] o que acontece é que nós temos uma linha grande, mas a venda unitária de cada produto é pequena. Nós não temos nenhum item dentro desses 300 que sozinho represente, signifique 3 ou 4\% das nossas vendas. Não chega a isso. Nem mesmo o War chega a isso. Então a venda é bem pulverizada mesmo. Então, acaba não se justificando a gente fazer uma pesquisa para determinada linha.

Uma observação cuidadosa das palavras do entrevistado indica que a empresa acredita não existir escala necessária para realizar pesquisas direcionadas às diferentes linhas de produtos que a empresa oferece ao mercado. Para o informante, a empresa até poderia realizar pesquisas mais generalistas, tentando identificar as características do mercado como um todo, ao invés de se especializar nos segmentos de mercado que consomem suas diferentes linhas de produto, mas essa estratégia não se faz necessária, já que esse tipo de informação é entregue por terceiros.

O entrevistado indica que os principais fornecedores deste tipo de pesquisas são os licenciadores, que as fornecem buscando convencer a empresa de que seus personagens são oportunidades rentáveis de licenciamento. Ele cita como principais fornecedores de pesquisa os canais Disney, 
Nickelodeon e Cartoon Network. De acordo com o gerente da Grow, essas pesquisas são bastante úteis para que a empresa possa perceber as tendências que estão movendo o mercado.

A empresa se apóia na experiência dos seus executivos mais experientes para a definição das estratégias de lançamento, escolha de personagens para licenciar etc. O entrevistado comenta que esses executivos têm por volta de 15 ou 20 anos no ramo, sendo que ele mesmo, com seus 9 anos de experiência, também participa desse processo decisório mais fundamentado no feeling ${ }^{32}$. Esse comitê, responsável pelas decisões mais importantes da empresa, é composto pelo próprio gerente de marketing, pelo diretor de marketing e pelo dono da empresa, que apesar de ter uma participação mais efetiva na parte financeira, participa de algumas decisões, principalmente daquelas que envolvem o desembolso de uma quantia significativa de capital, como na compra de uma licença.

Seguindo, o informante acredita que a empresa reconhece que existem diferenças culturais entre os diferentes países e, sendo assim, não haveria razão para que um produto que é sucesso no exterior (Estados Unidos, Europa e Japão) não tenha o mesmo nível de sucesso no Brasil. Destarte, a empresa trabalha observando o comportamento desses mercados (consumidores e empresas) para balizar suas decisões no Brasil.

Apesar da Grow não realizar pesquisa de segmentação, ela tenta de alguma forma compreender melhor o seu mercado de atuação por meio das pesquisas cedidas pelos licenciadores. Cabe salientar que as informações fornecidas pelos licenciadores podem ter vieses relacionados aos objetivos do licenciador, o que é um risco inerente ao uso de dados secundários (KERIN et al., 2007). A empresa se apóia em três fatores para direcionar suas estratégias: (a) pesquisas realizadas por terceiros, (b) observações de mercados estrangeiros e (c) experiência acumulada pelos gestores da empresa.

É claro que esforços de pesquisa realizados pela própria empresa lhes trariam algumas vantagens, pois a "segmentação pode ser usada para ganhar uma vantagem competitiva por considerar os mercados de forma diferente dos seus competidores" (MCDONALD e DUNBAR, 1998, p.29).

\footnotetext{
32 expressão em inglês adaptada ao vernáculo português com o significado de sentimento, crença
} 
Isso não acontece porque as informações que a empresa recebe de seus licenciadores estão sendo disponibilizadas para outros membros do mercado, ou seja, para seus concorrentes. Hooley e Saunders (1996) destacam que o grande perigo de não segmentar aparece quando os seus concorrentes estão conduzindo esforços de segmentação. Caso nenhuma empresa esteja fazendo esse tipo de ação, a competição se dará com base em outros aspectos.

Richers (1991) salienta que, quando as empresas não conduzem esforços de segmentação, a competição passa a ocorrer na qualidade dos produtos ofertados, sendo a diferenciação de produto bastante importante para que a empresa se imponha no mercado e consiga algum nível de sucesso. Este parece ser o caso desta organização.

Ao introduzir um produto no mercado a companhia acompanha o seu desempenho de forma bastante próxima, realizando comparações com as estratégias adotadas pelas empresas que lançaram o produto no exterior. Dessa forma, analisa o entrevistado, é possível perceber se uma eventual diferença entre o desempenho do produto no exterior e no Brasil é resultado de algum problema de preço, distribuição ou comunicação. $\mathrm{O}$ entrevistado indica que a empresa analisa os 3 Ps que estão sob seu comando, deixando de fora o $\mathrm{P}$ de produto, o qual já está estabelecido com base na imitação do que está sendo feito no exterior.

A definição da faixa etária para qual o brinquedo será direcionado é feita por meio do feeling dos executivos da empresa. $\mathrm{O}$ entrevistado ressalta que, em alguns casos, existem dúvidas sobre a faixa etária mais adequada. Nesses momentos, a empresa se apóia em alguns testes, que podem acontecer de duas formas: (a) a empresa traz crianças para a empresa e testa os produtos; ou (b) a empresa leva seus produtos para algumas escolas com as quais tem parcerias e testa os produtos com os alunos. $\mathrm{O}$ gerente indica que esses testes são raros, considerando que, na grande parte dos casos, a decisão é tomada com base no feeling mesmo.

$\mathrm{O}$ uso da idade como um indicador dos mercados que determinado produto atende acontece por influência, em parte dos requisitos do Inmetro e em parte da literatura que aborda o mercado infantil. Autores como McNeal (1992; 1999), Siegel et al. (2001), Azzarone (2003), Lindstrom (2003a; 2003b), Montigneaux (2003) e Acuff e Reihner (1997), trabalham suas recomendações 
para empresas que pretendem lidar com o segmento infantil com base em faixas etárias. Isso acontece porque esses autores fundamentam suas considerações na estrutura criada por Piaget (1959). Este autor estabeleceu os limiares de idade que separam crianças com diferentes capacidades cognitivas. É com base nesses limites que a Grow tenta estabelecer a faixa etária correspondente ao produto que está lançando. O entrevistado suporta essa consideração quando diz que a empresa analisa a capacidade da criança em relação à leitura, ao raciocínio para compreender regras e ao trato com peças pequenas para determinar a faixa etária do produto sendo introduzido.

É interessante observar que, como a decisão da faixa etária para qual o produto é destinado acontece com base no feeling dos gestores da empresa, torna-se necessário colocar uma idade um pouco acima do que a Grow imagina que seja a idade ótima para o correto uso do produto.

[...] via de regra nós preferimos indicar para uma faixa etária acima, mesmo sabendo que algumas crianças têm capacidade de jogar até numa faixa etária menor. A gente tem que usar ai a média, Para um jogo como War, a gente sabe, indica para a partir de 10 anos, a gente sabe que tem criança de 9 ou 8 anos, um pouco mais esperta que joga e joga bem.

O entrevistado também sinaliza para o uso de questões relacionadas ao processo de socialização da criança quando indica que "muitas vezes é em função do tema, em função do personagem que a gente define". Nesses casos, a organização está atenta para os personagens que fazem parte do mundo da criança, sendo que esses personagens se tornam representativos para a criança por meio dos agentes de socialização, os quais podem ser a mídia, a escola, amigos, parentes, vizinhos etc. (KAIL, 2004).

Outro fator indicado pelo informante como relevante para o processo de segmentação é a variável renda. $\mathrm{O}$ entrevistado esclarece que a empresa possui diferentes linhas de produtos a preços diferenciados, variando de seis (6) ou sete (7) reais para um quebra-cabeça mais simples, até cem (100) reais para o jogo War Especial. O gerente entende que produtos mais baratos têm um público bem maior em relação a produtos mais caros, citando o exemplo do War, que vende cerca de 150.000 unidades ano para toda a família, em comparação à linha do Super-Trunfo, que custa cerca de 9 reais e vende cerca de 750.000 unidades ano. 
Resumidamente é possível trazer algumas considerações gerais sobre o processo de segmentação da empresa:

- O processo decisório da empresa está alicerçado na experiência dos seus gestores, na observação de mercados estrangeiros e em pesquisas disponibilizadas pelos licenciadores.

- A empresa utiliza duas variáveis de segmentação para compreender o mercado, idade e renda. Além disso, também leva em considerações as capacidades da criança para comprar/consumir seus produtos no momento da definição do público-alvo.

\subsubsection{Estratégia de posicionamento}

Conforme a estrutura estabelecida para o primeiro caso analisado, esta etapa do trabalho seguirá a classificação de posicionamento apresentada por DiMingo (1991).

\subsubsection{Estratégia de posicionamento de mercado}

A empresa identifica que suas principais linhas de produto são os Jogos de Tabuleiros e os bonecos de vinil injetados. No mercado de jogos de tabuleiro, os principais concorrentes são as empresas Estrela e Toyster. A organização está aguardando uma grande mudança no mercado nacional, com a chegada da Hasbro, maior fabricante de brinquedos do mundo. Até então, a Hasbro trabalhava com parceiros locais, distribuindo seus produtos com duas marcas, sendo a própria Grow um desses parceiros, como nos exemplos da Ilustração 28. 


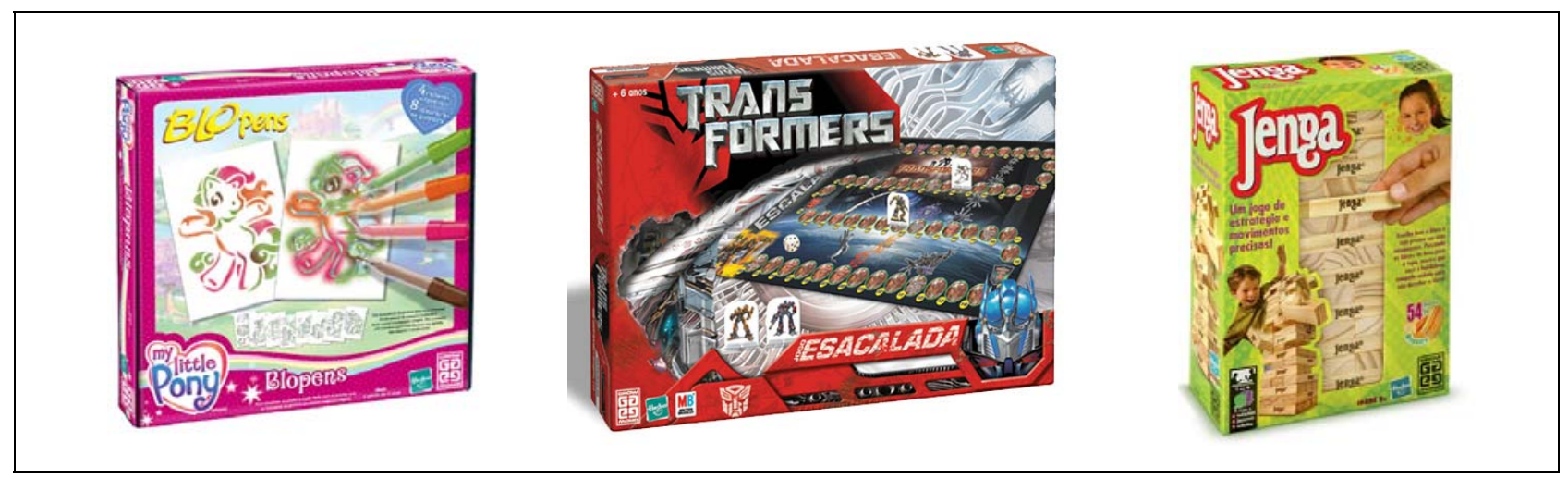

Ilustração 28 - Brinquedos Grow-Hasbro FONTE: GROW; 2008.

A partir deste ano, no entanto, a Hasbro pretende retomar a propriedade e direitos de suas marcas e, por meio de um escritório próprio, lançar e distribuir seus produtos. O entrevistado faz uma preocupante análise dessa mudança no mercado. De acordo com suas palavras, é possível compreender que o mercado nacional de brinquedos está a ponto de passar por uma grande mudança:

Vai ser um desafio grande que a gente vê que a maioria dos mercados onde estão Mattel e Hasbro as indústrias nacionais acabaram sofrendo bastante ou quase sumiram, isso América Latina inteira e outros locais também. O Brasil é um dos poucos países do mundo que ainda tem uma indústria nacional, não diria forte, mas assim significativa. Então a partir desse ano a gente vai ter uma mudança ai.

A disputa com os atuais concorrentes é feita no campo dos licenciamentos. O entrevistado esclarece que, quando se compra a licença de um personagem para um determinado tipo de produto, existe a questão da exclusividade e, sendo assim, no caso da Grow comprar a licença do Homem-Aranha para quebra cabeças, todos os quebra-cabeças lançados com a figura do HomemAranha serão da Grow. Dessa forma, toda a competição ocorre na escolha de qual empresa terá determinada licença. Essa competição é explicada pelo entrevistado e acontece da seguinte forma:

- A agência que tem os direitos de determinada licença procura a Grow ou outros interessados com cerca de um ano de antecipação para divulgar determinado filme que está para ser lançado. Essa agência apresenta os dados referentes ao lançamento: data 
de lançamento, montante a ser investido no lançamento, qual distribuidora vai ser responsável pelo filme, entre outras informações relevantes.

- Com base nessas informações, as empresas interessadas fazem uma proposta de compra da licença. Essa proposta de compra da licença é baseada numa garantia mínima oferecida pelo interessado. Essa garantia é baseada na previsão de vendas dos produtos que serão lançados com o personagem. Em alguns casos esse valor chega a 20.000 ou 40.000 dólares.

- A agência decide qual empresa irá receber a licença com base na oferta máxima apresentada. As empresas que querem comprar a licença não recebem informações sobre os valores oferecidos pelos concorrentes.

O entrevistado entende que as decisões sobre o valor a ser oferecido acontece com base na percepção dos gestores sobre o nível de sucesso que o filme vai ter e o conseqüente apelo que ele terá junto ao mercado. Essa decisão é tomada com base nas informações recebidas e no conhecimento de mercado que os executivos da empresa possuem, mas esse processo não é isento de erros e, em alguns casos, acaba gerando encalhes para a empresa. O entrevistado cita um exemplo para esclarecer essa questão:

Uma aposta que a gente teve no ano passado e foi um grande fiasco foi essa linha aqui dos vegetais. Nós licenciamos com o SBT, era um seriado que em termos de audiência estava super bem no ano passado. Pra um público pré-escolar que a gente não tinha nenhum seriado fazendo sucesso até então. TV aberta, SBT, 8 pontos de audiência, a gente achou que ia. Vendeu muito próximo do zero.

O potencial para perdas é minimizado pela gráfica própria que a empresa possui. Dessa forma, produtos que são produzidos internamente têm um custo produtivo menor, tornando o impacto de um lançamento fracassado menos prejudicial à organização. Nos casos em que a empresa precisa investir na fabricação de um molde, em maquinaria e ferramentas produtivas, o impacto de um fracasso é maior. Percebe-se aqui que a empresa considera a gráfica própria como um elemento importante para a redução de riscos, podendo ser até considerada uma vantagem competitiva sobre outras empresas que não têm esse tipo de estrutura.

Abaixo estão resumidas as principais considerações sobre o processo de posicionamento de mercado da empresa: 
- A empresa não realiza nenhum processo estruturado de planejamento, baseando suas decisões no feeling dos gestores.

- A empresa entende que o mercado passará por um processo de grande mudança nos próximos anos com a entrada do maior fabricante mundial de brinquedos, a Hasbro.

- A empresa avalia que produtos baseados em licenças de personagens de sucesso são garantia de vendas.

- A empresa criou a oportunidade de desenvolver economias na produção ao ter uma gráfica própria, gerando assim uma vantagem competitiva sobre seus concorrentes.

\subsubsection{Estratégia de posicionamento psicológico}

Conforme aportes da literatura apresentados anteriormente (DIMINGO, 1989, AAKER, 1998; HOOLEY e SAUNDERS, 1996), esta etapa do trabalho procurará compreender não somente os esforços de comunicação para criar um determinado posicionamento, mas também os esforços relacionados ao desenvolvimento de produto, precificação e distribuição.

\subsection{Estratégia de posicionamento psicológico - produto}

A Grow trabalha atualmente com cerca de 300 produtos, tendo um ritmo de lançamento de cerca de 150 produtos por ano. O entrevistado esclarece que muitos destes lançamentos são os mesmos produtos anteriores, mas atualizados ou com novos personagens. Por exemplo, um quebra-cabeça é lançado em um determinado ano com um personagem como o Homem-Aranha. No ano seguinte, passada a influência do lançamento do filme no mercado, se faz necessário buscar um outro personagem para estampar sua imagem nos quebra-cabeças. A Ilustração 29 exemplifica essa idéia, pois é possível verificar que o foco da empresa no momento atual são os lançamentos de produtos relacionados aos personagens Iron Man (Homem de Ferro) e Speed Racer, lançamentos de filme programados para 2008. 


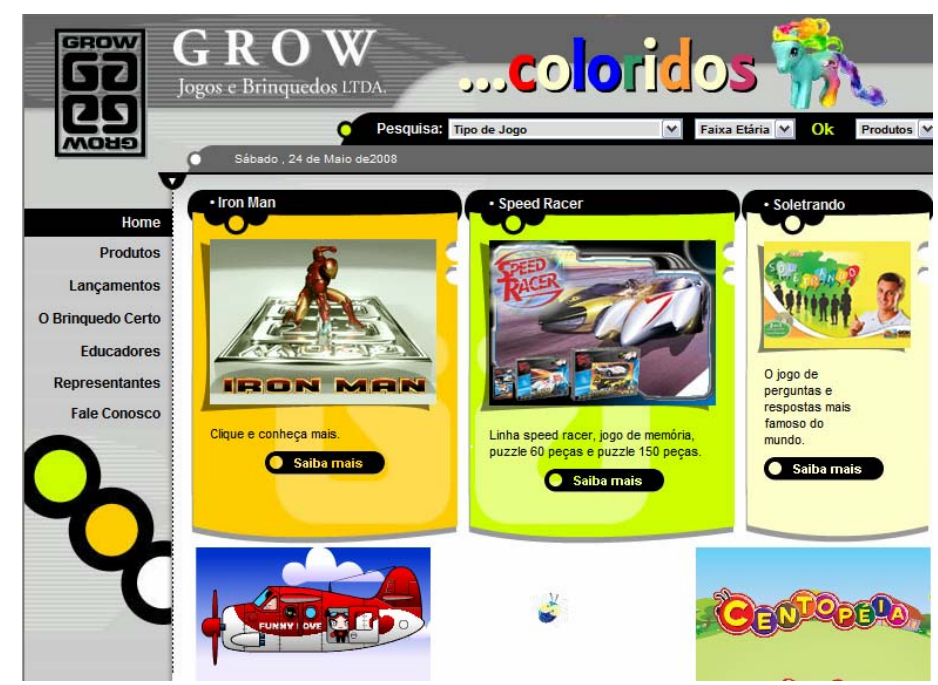

Ilustração 29 - Site da Grow Jogos e Brinquedos Ltda. FONTE: GROW; 2008.

A empresa entende que o ciclo de vida dos produtos no ramo de brinquedos é muito curto, sendo que são poucos os brinquedos que se mantém no mercado por prazos muito longos. Dessa forma, o gerente de marketing considera que a empresa deve estar sempre buscando por novidades, seja em brinquedos, seja em licenciamentos. Essa transitoriedade do mercado pode ser compreendida pelo foco que a empresa dá para produtos licenciados. O sucesso desse tipo de produto está diretamente relacionado ao sucesso dos personagens no cinema ou televisão. Passada a época do lançamento, é natural que o impacto do produto no mercado vá diminuindo, exigindo que a empresa relance os produtos com personagens atualizados. O entrevistado coloca essa idéia da seguinte forma: “o personagem que fez super sucesso num ano, no ano seguinte ninguém quer saber dele". O foco nos personagens por meio do licenciamento pode ser compreendido por meio de Montgneuax (2003), que salienta o papel desses personagens como forma de inserção da criança entre seus pares, tanto na escola, como na vizinhança, como dentro da própria família.

O entrevistado salienta que existem produtos que se mantém no mercado por períodos maiores, principalmente nos casos de produtos juvenil-adultos. O gerente destaca os casos de maior durabilidade no mercado: Imagem em Ação, Perfil, War e Cara Maluca. Esses produtos estão no mercado há 20 ou 25 anos, mas são considerados como exceções pelo informante.

O processo de escolha de uma licença e desenvolvimento do produto até o seu lançamento pode consumir cerca de 1 ano. A questão do licenciamento é destacada pelo entrevistado como a mais 
demorada, pois é necessário conseguir a aprovação do licenciador para os produtos a serem lançados. Por exemplo, ao desenvolver o boneco do personagem Shrek, a empresa se viu obrigada a fazer inúmeras rodadas de envio e recebimento de requisições de motivações até receber a aprovação final da Dreamworks, produtora responsável pelo filme.

Os produtos clássicos, como o War, que têm uma permanência maior no mercado, são repaginados periodicamente, na maioria dos casos após 4 ou 5 anos. Essa mudança no produto ocorre tanto nas embalagens como nos seus componentes. O próprio War está na sua $8^{\mathrm{a}}$ ou $9^{\mathrm{a}}$ versão.

Como a empresa possui uma linha de produtos bastante extensa, existe a necessidade de estar lançando produto de forma continua ao longo do ano. Convém destacar que o entrevistado indica que a Grow é uma exceção nesse sentido. Para a grande maioria das outras empresas, o que acontece é que os lançamentos estão focados no natal e no dia da criança, sendo a feira realizada pela Abrinq um dos momentos mais importantes do ano. Além dessa feira nacional, a Grow também participa de feiras internacionais para verificar quais são as tendências do mercado. Essas feiras acontecem geralmente entre janeiro e fevereiro, enquanto a feira da Abrinq acontece em abril.

Na feira da Abrinq, a empresa leva todos os seus lançamentos do ano, tanto aqueles que já estão prontos como aqueles que ainda estão sendo desenvolvidos. Neste último caso, a empresa procura levar um protótipo para sentir as reações dos varejistas aos produtos sendo desenvolvidos.

A empresa apresenta 4 caminhos diferentes para o seu processo de desenvolvimento de produto:

1) Produtos já existentes que são periodicamente repaginados. Esse tipo de lançamento não dá trabalho para a empresa, pois é só mudar a impressão do quebra-cabeça, o tema do jogo de memória e pronto.

2) Produtos que são trazidos de fora, sendo lançados aqui no Brasil pela Grow, e produtos que são trazidos do exterior, por meio de co-lançamentos (ex: parceria com a Hasbro). 
3) Produtos de criação nacional, produzidos por inventores/criadores que já têm um histórico de relacionamento com a Grow. Esses criadores periodicamente levam novas idéias para a empresa, que verifica a viabilidade da idéia. Dentre esses produtos nacionais, o entrevistado destaca o jogo Identidade Secreta, o Resposta Mágica e a Pizzaria Maluca (vide Ilustração 30).

4) Jogos que são encomendados pela empresa para os criadores/inventores. A empresa procura os inventores e solicita um jogo que seja adequado ao personagem que foi licenciado. A empresa fornece para o inventor informações referentes à história do jogo, os personagens que devem fazer parte, quantidade de componentes e custo. Dentro dessas limitações o inventor desenvolve a mecânica do jogo.

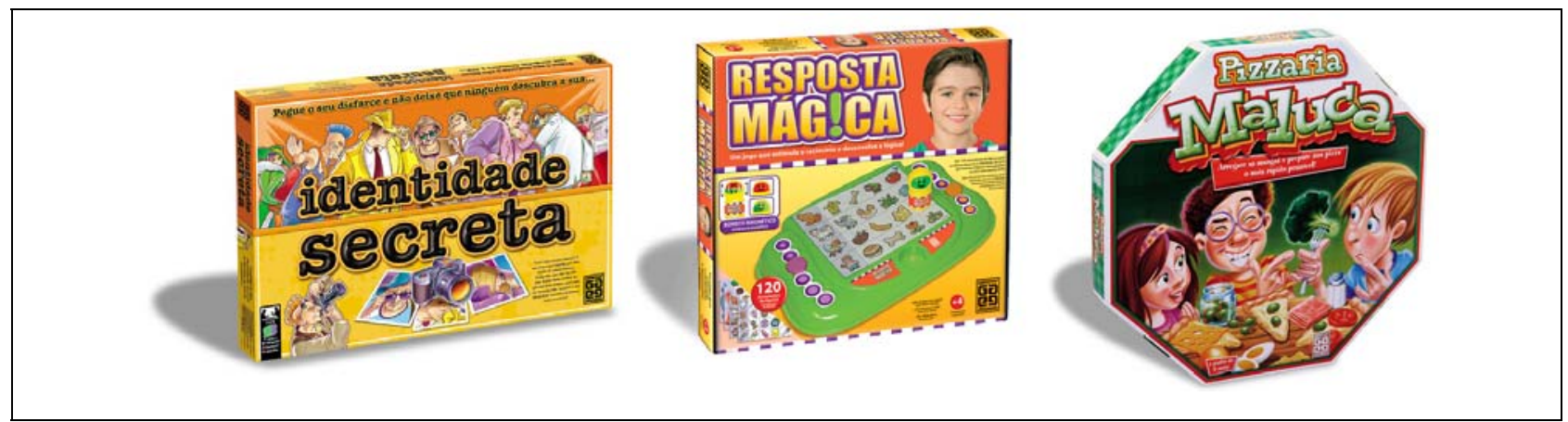

Ilustração 30 - Produtos nacionais lançados pela Grow Fonte: GROW; 2008.

Ao analisar as informações oferecidas pela empresa, percebe-se que ela trabalha de forma concomitante as duas estratégias de lançamento de produtos, a imitação e a inovação (MCNEAL, 1992). McNeal (1992) é categórico quando afirma que o caminho que apresenta maiores dificuldades, mas também maiores retornos, é o do lançamento de produtos inovadores. Isso sem considerar que, ao criar e lançar produtos próprios com características inovadoras, a empresa está construindo uma barreira competitiva contra a concorrência. $\mathrm{O}$ fato anteriormente relatado muitas vezes não é verificado, como no exemplo da Hasbro, que após utilizar da parceria para introduzir seus produtos no mercado, irá passar a produzi-los e comercializá-los por meio de operação própria. A Hasbro utilizou uma série de empresas nacionais para colocar seus produtos no 
mercado, construindo uma base de consumidores, que proximamente passará a ser de seus consumidores.

Ao colocar o exemplo de casos de brinquedos que foram desenvolvidos com base nas idéias dos inventores e foram lançados no exterior, criando um caminho inverso ao que normalmente acontece, o entrevistado dá suporte às considerações de McNeal (1992) sobre as possibilidades que a inovação traz.

A partir do que foi apresentado, indicam-se abaixo algumas considerações principais:

- O processo de desenvolvimento de produtos é realizado de inúmeras formas pela empresa: jogos já existentes que são atualizados; jogos trazidos do exterior, pela própria Grow ou em parceria com um fabricante estrangeiro; inovações trazidas por inventores; e encomendas realizadas para inventores.

- A empresa faz largo uso da estratégia de licenciamento, procurando sempre trazer personagens da moda.

\subsection{Estratégia de posicionamento psicológico - preço}

A empresa trabalha a questão do preço com base em dois fatores - o primeiro relaciona-se a sua própria gráfica, que permite que a empresa tenha algumas economias de custo; o segundo fator refere-se ao uso de licenças de personagens de sucesso, processo que gera um custo adicional por meio de garantias mínimas de venda e royalties pagos para o licenciador.

Os produtos da empresa distribuem-se numa linha de preços que varia de seis (6) reais até cem (100) reais para os produtos mais caros. Essas diferenças de preços terminam por gerar segmentos diferenciados. Enquanto os produtos mais baratos atingem até 700.000 unidades, os

produtos mais caros têm um mercado menor, atingindo 150.000 unidades de venda, como já relatado anteriormente. Os exemplos dados pelo entrevistado são referentes aos extremos dessa escala de preços e vendas. Um produto que vende bem, na visão da empresa, vende cerca de 20.000 unidades por ano. 
A garantia mínima paga para o licenciador pode chegar a valer 40.000 dólares. Se for considerado o valor oferecido pela empresa de 20.000 unidades como uma boa venda, tem-se uma média de 2 dólares agregados ao custo do produto em função de royalties. Para os mercados mais populares atendidos pela empresa, esse valor pode ser bastante restritivo.

O processo de decisão do preço dos produtos é trabalhado de forma similar ao processo de segmentação, ou seja, largamente baseado nas informações oferecidas pelas empresas licenciadoras e na experiência dos gestores da empresa. A questão das informações oferecidas pelas empresas licenciadoras têm as limitações decorrentes do uso de dados secundários, ou seja, problemas de confiabilidade na coleta, diferenças no objetivo e utilidade limitada (MALHOTRA, 2001; AAKER et al., 2003).

- No que se refere ao processo de precificação, dois fatores influenciam as decisões da empresa, são eles: (a) os valores pagos para obter a permissão para lançar determinado produto com um personagem e que tem um impacto negativo no processo; (b) o uso de uma gráfica própria que proporciona economias para a empresa em relação a concorrentes que não possuem essa capacidade.

- O processo de precificação é conduzido com base nas informações fornecidas pelas empresas de licenciamento e na experiência de mercado dos gestores.

- A empresa apresenta desde produtos com preços populares, até produtos de maior valor agregado e preços superiores.

\subsection{Estratégia de posicionamento psicológico - praça}

A primeira consideração que o entrevistado faz com relação a questões relativas à distribuição, diz respeito à abrangência das atividades da empresa no Brasil. A localização da fábrica faz com que o foco da empresa seja o mercado pelo Rio de Janeiro e São Paulo. Minas Gerais também tem uma participação relevante, seguido pela região Sul como um todo. A participação da empresa nas regiões Norte, Nordeste e Centro-Oeste é vista pelo entrevistado como muito fraca.

O entrevistado explica isso com base nas restrições de recursos para investimento na comunicação do produto. Ele indica que o esforço maior da empresa é o mercado de São Paulo, 
onde valores são investidos, tanto na mídia, como no ponto de venda. O informante finaliza seu raciocínio acreditando que grande parte do sucesso de um produto está relacionado com o investimento no ponto de venda. Acrescenta ainda o gerente que a empresa tem uma área específica para cuidar da promoção no ponto de venda, sinalizando a importância que o canal de distribuição tem para a empresa. O gerente sinaliza essa importância do trabalho no ponto de venda da seguinte forma: "Antigamente promotor funcionava pra dar uma ajuda mesmo na loja, o que acontece hoje é que se nós não temos esse promotor, nosso produto some ali dentro da loja”.

A distribuição, em alguns casos, pode ser o fator que responde pela baixa vendagem de determinado produto. A identificação desse tipo de ocorrência se dá por meio de comparações entre as estratégias de lançamento do produto em outros mercados.

Tomando como base as considerações elaboradas neste tópico, oferecem-se abaixo algumas considerações gerais:

- A empresa trabalha tem uma forte atuação junto ao varejo por meio de promotores de vendas.

- Em datas importantes são contratados promotores extra.

- A feira da Abrinq representa uma oportunidade de apresentar os produtos da empresa para o varejo.

- A empresa tem sua distribuição focada nas regiões mais próximas da empresa.

\subsection{Estratégia de posicionamento psicológico - promoção}

As estratégias promocionais da empresa são realizadas por áreas distintas. A organização tem uma área que cuida da mídia televisiva (de responsabilidade do entrevistado) e outra área que cuida da promoção no ponto de venda. Parte central das iniciativas de divulgação dos novos lançamentos acontece durante a feira da Abrinq, realizada anualmente em São Paulo no mês de Abril. Esse esforço de divulgação é direcionado ao canal de distribuição.

Já para o consumidor final, a empresa utiliza diversas ferramentas de comunicação para posicionar suas marcas. A principal delas é a mídia televisiva. O funcionário afirma que, 
paulatinamente, a TV a Cabo tem recebido maiores investimentos por parte da empresa. Dentre os canais abertos, a empresa centra seus esforços na Globo, SBT e Cultura. A inserção de comerciais nesses canais tem uma característica regional, o que casa com as limitações da empresa e sua proximidade física com o mercado de São Paulo e Rio de Janeiro.

A empresa procura posicionar as suas propagandas nos horários mais apropriados para atingir o segmento infantil, mas o entrevistado reconhece que, em parte dos casos, a empresa recorre ao método rotativo de inserções comerciais por razões financeiras. Dessa forma, o comercial aparece de forma rotativa num determinado período do dia, como por exemplo, das 8 da manhã até as 3 da tarde, ou 8 da manhã até as 8 da noite. $O$ entrevistado reconhece que essa estratégia não é a melhor, pois muitas vezes o comercial é alocado no intervalo de seriados bacanas e em outros momentos no intervalo de programas que não têm grande apelo junto ao seu público-alvo.

A empresa tenta direcionar suas inserções comerciais de acordo com o perfil do telespectador do programa, conforme pode ser percebido nas palavras do entrevistado:

[...] os canais têm 2 ou 3 seriados que estão estourados e o resto não é tão forte assim. Então se você quiser só naquele que está bem ali, ele tem um custo. Porque todo mundo quer, mas na medida do possível a gente procura focar, porque tem seriado mais femininos, tem seriados mais masculinos, ou mais pré-escolares.

Siegel et al. (2001) indicam que a propaganda pode ter como foco principal a criança, os pais ou ambos, já que estes são os responsáveis pela compra. Os autores salientam que a propaganda focada exclusivamente na criança apresenta resultados superiores, sendo, portanto, a mais indicada. A empresa faz uso dessa estratégia, focando suas propagandas exclusivamente nos infantes, contando com os pedidos destes junto a adultos para que a compra se concretize. Outra razão para tal reside no custo de inserir uma propaganda num horário que atinja os pais, geralmente no horário nobre (SIEGEL et al., 2001).

Acuff e Reiher $(1997,179)$ apresentam a idéia de que "A criança acima de 8 anos quer parecer mais velha, assim, em propagandas televisivas com crianças reais, estas devem ter uma idade ligeiramente superior àquela do público alvo". O entrevistado concorda com essa afirmação e faz uso dessa estratégia: 
Por exemplo, um produto que a gente imagina que vai vender para faixa etária de 10 anos, alguma coisa assim, os garotos que vão aparecer aqui no comercial, eles tem que ter 12 ou 13 , para aparecer que é um negócio, pra parecer não, muitas vezes é, o grosso a gente vai vender pra faixa etária de 10, mas se o garoto de 10 vê um garoto de 13 ali brincando o negócio é bacana, vai pra um público mais velho. Se a gente fizer com uma criança de 10 a gente corre o risco da criança de 10 não se identificar com aquele garoto lá [...] - É uma criança, eu não brinco com isso, eu brinco com essas coisas mais.

Além da mídia televisiva a empresa trabalha também a mídia eletrônica por meio de um site, que tem mais uma função de apresentar os produtos, não estabelecendo um contato maior entre o consumidor e a empresa. A organização também trabalha na internet por meio de parcerias com outros sites que recebem autorização para dar acesso a uma versão eletrônica dos jogos da empresa, como pode ser verificado no exemplo do site do Terra (vide Ilustração 31).

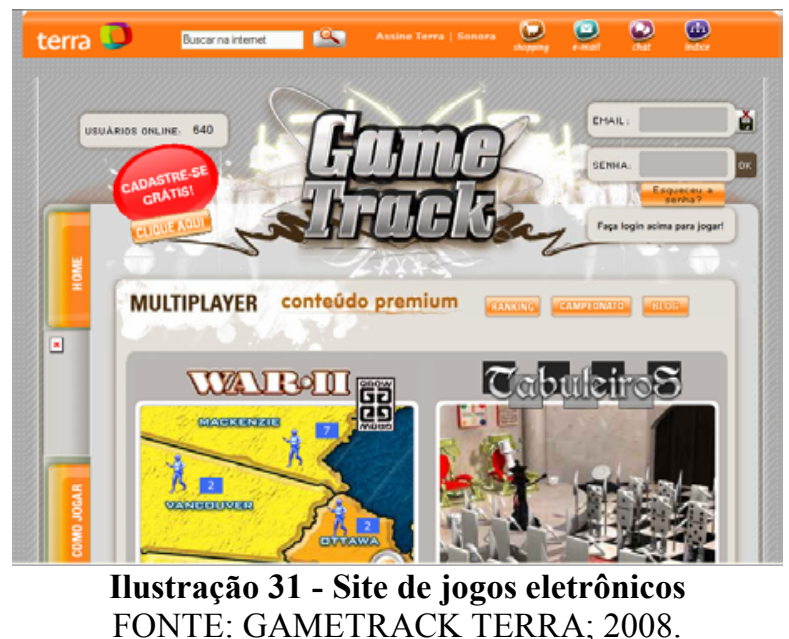

Além do War, também estão disponíveis na internet outros jogos como Super Trunfo e Imagem em Ação. Na opinião do entrevistado, essa iniciativa permite que amigos/parentes em locais distantes joguem os jogos da empresa, e possam assim adquirir alguma predileção pelo jogo.

A empresa também realiza ações especiais em shopping centers. Essas ações acontecem em datas comemorativas, como no natal e no dia da criança. Nesses momentos, a empresa trabalha disponibilizando seus produtos para as áreas de lazer do shopping, onde estão as crianças brincando. Um dos produtos que é disponibilizado nessa área é o resultante da parceria da Grow 
com a Ediouro para o lançamento de um jogo Coquetel, propriedade da Ediouro. Para essa parceria, foram feitos comerciais, inseridas propagandas nas revistas e no site da Ediouro.

As parcerias também proporcionam ações cooperadas com jogos que são resultantes da relação com a Hasbro. Conforme indicação do entrevistado, essa parceria vai terminar proximamente e, portanto, esse tipo de ação não será mais realizada com essa empresa em particular. $\mathrm{O}$ entrevistado considera que a junção de marcas tem uma conotação positiva na percepção dos consumidores.

Outras ações realizadas incluem a distribuição de produtos da empresa como brindes. Em um destes casos, o Super-Trunfo foi incluído nos sacos de ração de 15 quilos da Purina. A edição inserida no pacote foi especialmente desenvolvida para tanto, utilizando-se cães no jogo. Outra ação especial de brindes foi conduzida no Rio de Janeiro, onde o leitor do jornal Extra podia conseguir jogos em miniatura. Para ganhar o jogo, o leitor deveria colecionar 7 selos ao longo da semana e pagar R \$ 9,90. Para essa ação, a empresa manufaturou edições especiais de clássicos da empresa, como por exemplo, o War, o Can-Can, Perfil 3, Imagem em Ação 1 e Mega Trunfo (edição especial do Super Trunfo).

No que se refere a brindes, a empresa também trabalhou junto a Michelin ${ }^{33}$, produzindo miniaturas do mascote da empresa para serem distribuídos em revendas de pneus. Também, foram lançados bonecos especiais do Cauê, mascote do Pan do Rio de Janeiro. De forma regular, a empresa também fabrica miniaturas Disney para serem distribuídas como brindes no Cinemark.

Conforme mencionado anteriormente, a empresa dá uma grande importância para ações no ponto de venda, pois considera que esse é um momento muito importante no processo de decisão do consumidor. Portanto, a empresa possui uma equipe de promotores contratados em tempo integral, que são responsáveis por fazer o trabalho ao longo do ano. Para os períodos especiais, a empresa contrata promotores temporários, principalmente para o natal e o dia da criança. Esses promotores trabalham a colocação de material promocional (testeiras de gôndola, móbiles, cartazes entre outros).

\footnotetext{
${ }^{33}$ Grupo francês especializado no comércio de pneus.
} 
O entrevistado analisa a questão das ações no ponto de venda e considera que, se não for feito esse trabalho, o espaço destinado aos produtos na empresa diminuirá sensivelmente, causando problemas na venda dos produtos. No entanto, essa preocupação não resulta na compra de espaço no varejo. De acordo com o entrevistado, esse tipo de estratégia é realizada apenas pela Mattel, sendo que as outras empresas do ramo de brinquedos se recusam a participar desse jogo que é bastante comum no ramo de supermercados. O que a Grow faz periodicamente é pagar para aparecer no tablóide ou encartes de varejistas, expondo alguma promoção com os produtos da empresa.

Com relação à inserção de produtos da empresa no meio da programação televisiva ou de cinema, o informante destaca que essa prática acontece de forma inversa, por iniciativa da produtora realizando o programa. Ele cita o caso da Rede Globo, que procurou a empresa para solicitar que fossem disponibilizados alguns produtos para serem utilizados em determinada cena de uma novela.

Acuff e Reiher (1997) indicam que as empresas que pretendem atender o consumidor infantil devem realizar ações em cinco (5) locais específicos, lugares onde as crianças estão: em casa, na escola, na comunidade, nas lojas e em carros. A Grow tem realizado esforços para atingir essas crianças em casa, por meio de propagandas na televisão, na comunidade, por meio de ações nas áreas recreativas dos shopping centers, e nas lojas, por meio das ações de ponto de venda. A empresa poderia desenvolver atividades mais próximas a determinadas escolas, distribuindo os seus jogos. Ademais, poderia trabalhar com as emissoras de rádio, que apesar de terem seu alcance a uma região e público restritos, apresentam um custo bastante inferior em comparação à mídia televisiva.

Roberts et al. (1999) identificam que a presença da televisão no quarto de crianças norte americanas tem aumentado consideravelmente. É possível que o mesmo fenômeno esteja ocorrendo no Brasil e, se for este o caso, a estratégia da empresa em focar seus esforços na mídia televisiva seria produtiva. As inserções na televisão paga têm uma abrangência menor, pois o alcance desta mídia ainda não atingiu no Brasil níveis que são alcançados nos Estados Unidos. 
De acordo com Netto (2006), a televisão aberta está presente em 97\% dos domicílios, enquanto a televisão paga está presente em apenas 5,4\%, já nos Estados Unidos a participação da televisão a cabo chega ao patamar de 58\% das residências (CABLE, 2008).

- A empresa utiliza a propaganda televisiva como ferramenta principal, mas apenas para alguns produtos. Nessas propagandas utilizam-se atores mais velhos que o público-alvo.

- A empresa também realiza esporadicamente ações promocionais em shopping centers.

- São realizadas atividades junto ao varejo, como participação em tablóides e encartes e trabalhos promocionais no ponto de venda.

- A empresa disponibiliza um site que serve para apresentar os produtos da empresa, sem oferecer a oportunidade da compra on-line ou da comunicação mais efetiva entre a empresa e os consumidores. Parceria com outros sites disponibilizam alguns jogos da empresa para o jogo entre usuários da rede.

\subsubsection{Resumo da análise da Grow Jogos e Brinquedos Ltda}

Em sintonia com a forma como foi finalizada a análise do caso da Pica Pau, oferece-se na Ilustração 32 um esquema similar ao que foi apresentado anteriormente. 


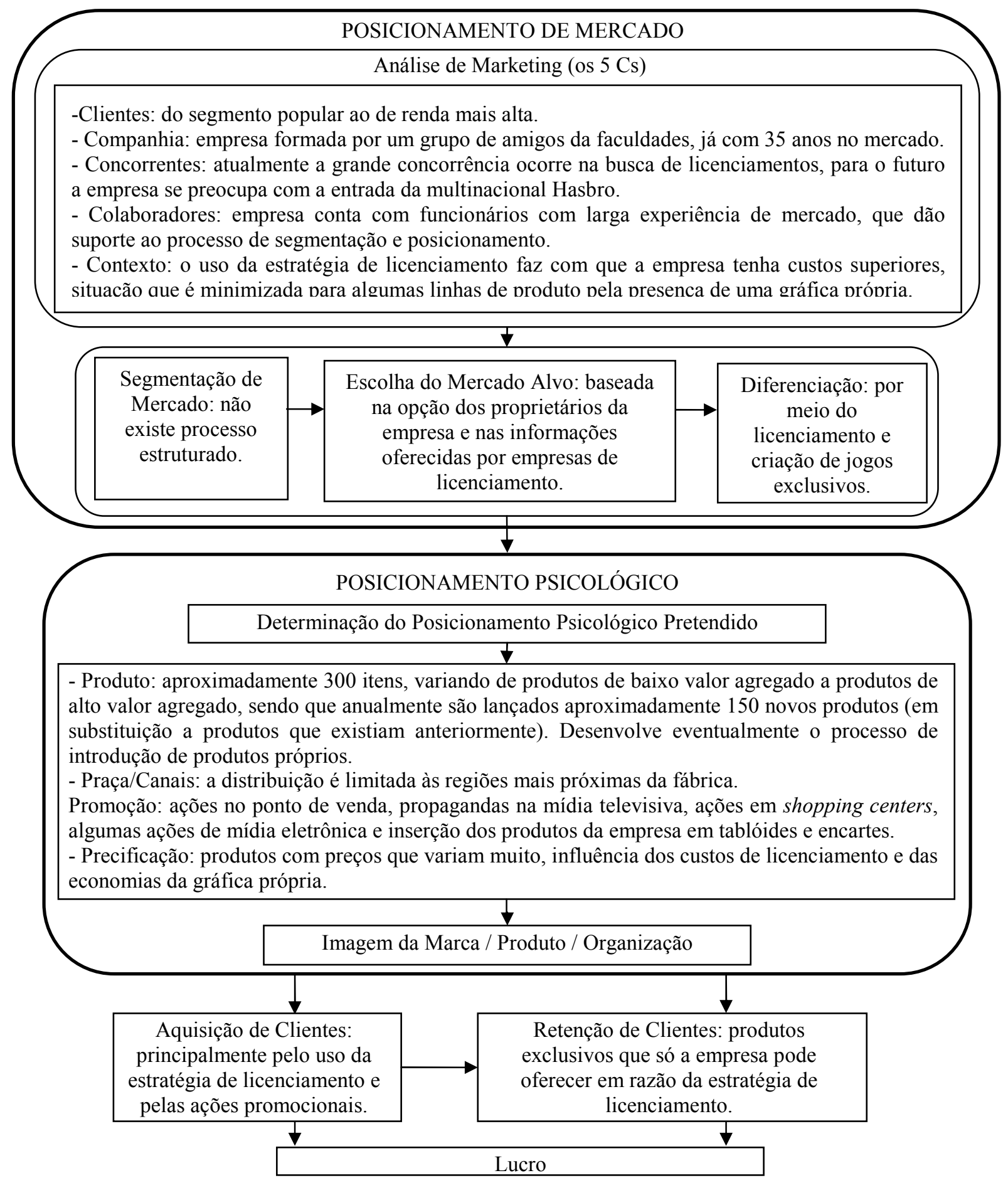

Ilustração 32 - Processo de segmentação e posicionamento da Grow Jogos e Brinquedos Ltda Fonte: Coleta de dados.

Ao apresentar este esquema representativo das atitivades de segmentação e posicionamento da Grow Jogos e Brinquedos Ltda finaliza-se esta etapa do trabalho, procedendo-se então para a análise do último caso abordado por este trabalho. 


\subsection{Caso 3 - Mitra Officina de Criação}

A empresa Mitra Officina de Criação foi criada por dois artesãos, Jorge Massao Takehara (engenheiro de produção) e Marta Giardani (pedagoga e artista plástica) em 2002. O foco da empresa é o brinquedo educativo e atua principalmente na região da Grande São Paulo e interior.

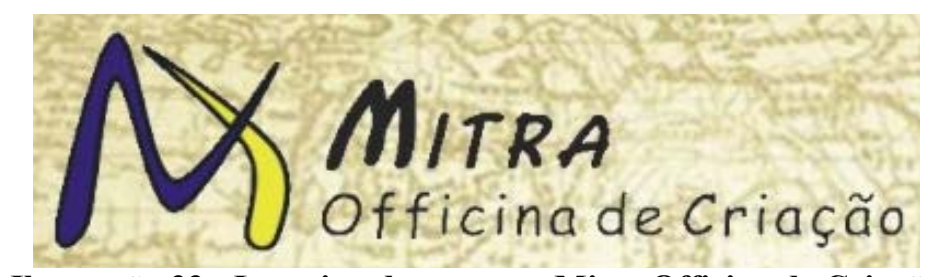

Ilustração 33 - Logotipo da empresa Mitra Officina de Criação FONTE: MITRA; 2008.

A empresa trabalha basicamente quatro linhas de jogos. A primeira linha de produtos, exposta na Ilustração 34, consiste numa coleção de jogos de tabuleiro que vem desde a época das civilizações antigas até os tempos atuais. Os produtos são feitos em MDF e têm um formato de livro.

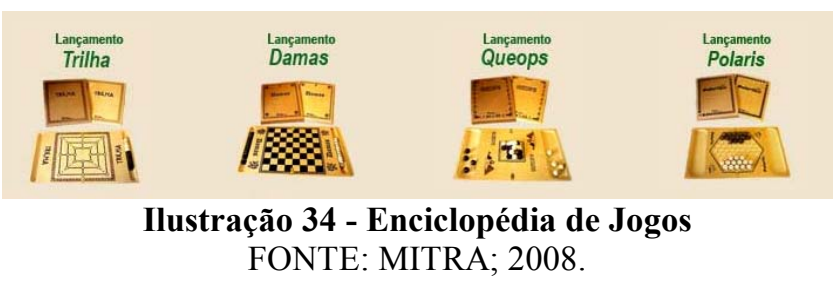

A segunda linha de produtos da empresa abrange diversas opções de entretenimento, constituída por jogos praticados nos mais inusitados países, como Zimbábue (jogo Tsoro), Filipinas (jogo Tapatan) e Índia (Kaooa).

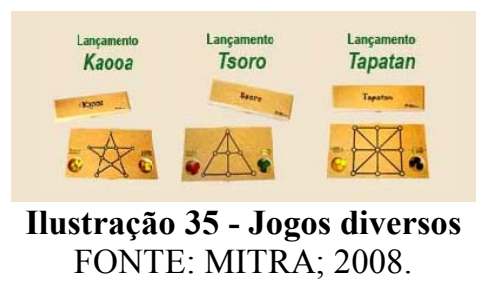

A terceira linha de produtos da empresa é a composta por desafios, como Pão Duro, Porteira, Tetrabol entre outros. 


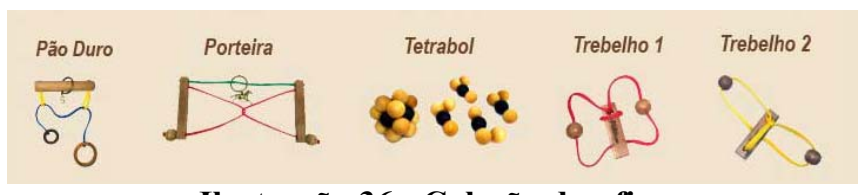

Ilustração 36 - Coleção desafios

FONTE: MITRA; 2008.

A derradeira linha de produtos da empresa é o mais novo lançamento - o produto Monte-Car Tunados, que fornece para o consumidor todos os apetrechos para pintar e montar um carrinho de brinquedo da forma como quiser.

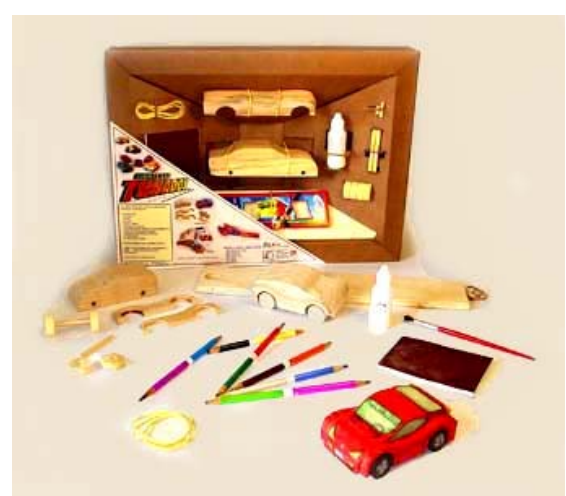

Ilustração 37 - Monte-Car Tunados FONTE: MITRA; 2008.

A empresa afirma desenvolver seus brinquedos como um instrumento de educação e de entretenimento. Apresenta-se abaixo um trecho retirado do site da empresa e que descreve os objetivos e filosofia da empresa (MITRA, 2008).

Acreditamos que a capacidade de visualização e treinamento da memória, necessária para desenvolver a inteligência e a criatividade, pode ser exercitada por meio de jogos e brinquedos que exigem o uso da imaginação, do raciocínio, ou habilidades motoras. Eles também colaboram no aprendizado das normas sociais, ou seja, enriquecem nosso desenvolvimento intelectual, social e criativo.

\subsubsection{Estratégia de segmentação}

A empresa Mitra é uma micro-empresa, constituída por apenas duas pessoas que trabalham de maneira informal na própria residência do casal. O proprietário da fábrica relata que seu enfoque é na criação do produto, não sendo desenvolvidos nenhum esforço de pesquisa, o que seria um 
dos primeiros passos no processo de segmentação (AAKER e DAY, 1989). É possível encaixar a empresa na primeira etapa do desenvolvimento do marketing, a era da produção (KERIN et al., 2007). Nessa época, "[a] noção central era que os próprios produtos é que deveriam se vender, assim o principal problema das empresas era a produção, não o marketing" (KERIN et al., 2007, p.19). De acordo com o informante, a empresa está primordialmente focada no desenvolvimento de seus produtos, acreditando que a alta qualidade e o grande apelo educativo são os principais determinantes no processo de tomada de decisão de consumidores preocupados com a questão educativa. Isso não significa que a empresa está totalmente desvinculada da preocupação com o marketing, mas sim que ainda está mais preocupada com a elaboração de seus produtos.

A Mitra define o segmento em que atua da seguinte forma: "[d]entro desse segmento (brinquedo pedagógico), o nosso é mais especifico ainda, porque o nosso foco são jogos de tabuleiro, de madeira". Este é mais um indicativo da percepção da empresa de que o seu foco estratégico está direcionado para o produto, e que da definição deste deveria surgir o público da empresa.

O proprietário afirma não possuir recursos para investir em marketing, isso reafirma a preferência da empresa em focar os seus esforços no desenvolvimento dos produtos, como pode ser observado na seguinte passagem: "se tivesse capital, recurso, para fazer uma campanha de marketing, colocar uma publicidade na televisão, que ia aumentar o mercado, tenho certeza que iria".

Apesar de existirem riscos na não segmentação, eles são reduzidos quando nenhuma empresa está realizando esforços de segmentação (HOOLEY e SAUNDERS, 1996). É de se esperar que, em um nicho de mercado como o de brinquedos educativos, raras organizações realizem esforços deste tipo. Nestes mercados, a competição deriva para a qualidade do produto (RICHERS, 1991), por isso se justifica a preocupação da empresa em produzir produtos que priorizem este atributo. A qualidade, no caso da Mitra Officina de Criação, está baseada em uma filosofia de negócios que prioriza um produto que tenha um impacto positivo no desenvolvimento da criança. Também faz parte dessa preocupação com a qualidade do produto o uso de materiais reciclados, que também transmitem uma mensagem diferenciada para o consumidor. 
A definição do público-alvo por meio da indicação da faixa etária é feita com base em duas informações: (a) a idade recomendada no jogo original; e (b) a "complexidade das regras, complexidade motora, se exige mais do raciocínio ou não". Por contar com o apoio de uma pedagoga, a empresa tem a capacidade de fazer uma análise mais aprofundada das capacidades da criança para consumir o brinquedo de forma correta. A estratégia de definição da faixa etária para a qual o brinquedo é destinado está fundamentada em questões relacionadas principalmente ao desenvolvimento cognitivo, ou seja, a capacidade da criança em lidar com determinadas operações ao longo de seu crescimento (PIAGET, 1959; KAIL, 2004).

Os produtos da empresa custam ao consumidor cerca de 40 reais, isso decorre dos custos de produção da empresa, conforme explica o entrevistado: "[...] o meu vai sair em torno de 40. Eu não vou conseguir colocar a um preço menor por causa do processo, da forma de produção". Esse nível de preço, por si só coloca o produto como sendo acessível somente a um determinado segmento, mas existem conflitos nas informações prestadas pelos entrevistados: "as pessoas pegam um jogo nosso e acha caro, pelo preço [...]. Tem gente que, muita gente que liga pra gente e acha um absurdo a gente vender tão barato, em compensação têm outros que falam que é muito caro”. É possível compreender que o brinquedo educativo tem apelo para diferentes consumidores pertencentes a diferentes classes sociais, uns acham 40 reais um preço muito alto, enquanto outros acham esse preço muito barato pelo que a empresa oferece.

A partir das informações acima, percebe-se que o público-alvo da organização é descrito principalmente pela predileção por brinquedos educativos, sendo que, em alguns casos, esse consumidor é de uma classe social mais alta e, em outros, mais baixa, reconhecendo o produto como caro. A empresa está em um estágio que Lambin (2000) denominou macro-segmentação, ou seja, a empresa apenas definiu o mercado onde pretende atuar. $O$ autor sugere que uma empresa deve primeiro definir o seu mercado de atuação, para depois conduzir ações de microsegmentação neste mercado, para definir as características que permitem compreender melhor esse mercado. A idéia de Lambin (2000) de certa forma pressupõe que a empresa primeiro decide uma área de atuação ou um determinado tipo de produto para comercializar, para depois adaptar sua oferta para as diferentes características desse segmento. No caso da Mitra, essa idéia consegue explicar o atual estágio em que a empresa se encontra, pois foi a partir das habilidades 
dos proprietários e de uma predileção por trabalhar com brinquedos que a empresa determinou o seu enfoque.

Johnson (1971) propõe que o processo de segmentação deveria ser a fonte da descoberta dos potenciais posicionamentos que a empresa poderia escolher para seus produtos. No caso da Mitra, essa idéia seria muito útil, pois existem indícios de que a forma como o produto é oferecido ao mercado causa dúvidas e questionamentos diversos entre os consumidores, principalmente com relação ao preço. Diante dessas considerações, conclui-se que seriam úteis atividades de segmentação de mercado para esta empresa, visando adaptar a oferta da empresa, melhor direcionar o seu esforço de marketing ou escolher de forma mais adequada os mercados que pretende servir.

Finaliza-se essa parte do trabalho oferecendo algumas considerações gerais sobre a questão da segmentação para a empresa sendo analisada:

- A empresa não conduz atividades de pesquisa para segmentar o seu mercado.

- A empresa aposta na elaboração de um produto de qualidade para gerar apelo junto aos consumidores.

- A empresa encontra-se num estágio de macro-segmentação, tendo apenas definido de forma abrangente o seu mercado de atuação.

- A empresa define a idade adequada para o brinquedo com base nas questões relativas ao processo de desenvolvimento cognitivo da criança.

\subsubsection{Estratégia de posicionamento}

Esta etapa do trabalho divide-se em posicionamento de mercado e psicológico, conforme estrutura utilizada nos casos anteriores por sugestões de DiMingo (1991). Antes de iniciar a análise cabe salientar que, por a empresa não ter realizado um processo de segmentação, é provável que enfrente inúmeras dificuldades para posicionar sua oferta. 


\subsubsection{Estratégia de posicionamento de mercado}

O proprietário define que a empresa é uma fábrica de brinquedos pedagógicos de madeira. $\mathrm{O}$ entrevistado declara ainda que esse brinquedo pode ser definido por ser algo similar àquele que era fabricado pelo próprio pai ou avô da criança, nos tempos em que não existiam alternativas industrializadas. O entrevistado declara certa preocupação com a entrada de concorrentes chineses que estão fabricando produtos de madeira, mas em escala industrial. Ele considera que talvez o mercado de brinquedos de madeira não sobreviva à entrada destes concorrentes, sinalizando um descontentamento com a falta de apoio governamental para incentivar a microempresa nacional.

O informante vai além, indicando que o governo não só não apóia, como também atrapalha o processo da indústria. Ele cita o exemplo das exigências do Inmetro, que baixou uma portaria que aumentou de forma considerável os custos de aprovação de um brinquedo no órgão.

\footnotetext{
Um custo que antigamente, antes dessa portaria, girava em torno de 2400 reais foi pra quase 50 mil. Pra tirar o selo do Inmetro. É inviável pra gente, por quê? Porque os importados, tudo bem, eles vem com $5.000,10.000,50.000$ peças e eles certificam por lote, leva 50 peças lá pra fazer o teste. Pra eles o custo é ínfimo dividido nessa quantidade, pra nós, o nosso lote de produção é de 50 peças, como é que a gente vai mandar 50 peças pra fazer teste? [...] Então assim, pra quem é artesão, pequeno empresário, se tornou inviável.
}

A Mitra trabalha basicamente com madeira para a produção dos brinquedos, mas o informante esclarece que está muito difícil encontrar madeira de qualidade para trabalhar. Ele indica que grande parte da madeira de MDF produzida no Brasil vai para a exportação, sobrando no Brasil a madeira de pior qualidade. Os seus concorrentes chineses estão utilizando madeira de seringueira, reconhecendo que o acabamento desses produtos é bom, mas lançando dúvidas sobre outras questões como a toxidade da tinta utilizada por estas empresas. Essas dificuldades fazem com que a empresa se veja obrigada a utilizar madeira não certificada, indo de encontro com a filosofia da empresa.

Outro problema enfrentado pela fábrica de brinquedos diz respeito à propriedade intelectual das suas invenções. De acordo com a empresa, 
[...] em termos de criação, a maioria copia. Melhora uma coisa aqui, outra ali. A patente aqui é figurativa. Então a pessoa cria um brinquedo, antigamente tirava essa patente, mas não adiantava nada. Era lançar no mercado e todo mundo copia. Então não tem muito que fazer.

A empresa trabalha principalmente com jogos milenares e, por isso, não existe a possibilidade de se pedir a patente do jogo. O que a Mitra fez foi patentear o formato dos jogos, no formato de livro. O entrevistado diz que ainda não copiaram o formato livro para os jogos de tabuleiro, em razão do maquinário que foi idealizado pelo próprio, mas reconhece que qualquer pessoa com formação em engenharia poderia analisar o brinquedo e criar as ferramentas necessárias para produzi-los.

Embora não tenha sido feita uma cópia exata do produto oferecido pela empresa, já existe uma empresa do Paraná que oferece produtos similares em um site. $\mathrm{O}$ entrevistado diz ter preparado uma carta para enviar a este empresário com reclamações sobre a cópia.

Outro concorrente procurou o empresário para realizar uma parceria, mas ele não aceitou esse convite, pois seria parte minoritária no empreendimento. Além disso, o entrevistado levanta dúvidas sobre a forma como essa outra empresa atende o mercado. Esta produz o tabuleiro dos jogos em lona e utiliza peças plásticas, o que não se adequa à filosofia da empresa. Abaixo, algumas considerações do entrevistado sobre essa empresa e sua forma de trabalhar:

- [...] pra ele a possibilidade de lançamento é até maior, mais fácil, mas é em lona o jogo.

- Chama mais atenção? Chama. No caso dele é colorido, que no meu caso, pela limitação da minha estrutura tem que ser mono, monocromático.

- No caso dele, ele não se preocupa com isso, ele quer é vender.

- Então, isso me limita mais em termos de mercado. Mas, estamos ai.

Ao analisar as considerações acima, percebe-se que o entrevistado está totalmente envolvido com questão filosófica que rege a forma de trabalhar da empresa. Ele percebe que o produto do concorrente é mais atraente, tem mais mercado e que suas preocupações filosóficas restringem a atuação da empresa, mas permanece fiel aos seus princípios mesmo que isso o torne menos competitivo. Ao analisar de forma rápida esta questão seria possível entender que a filosofia que rege as ações da empresa está minando sua capacidade produtiva, porém talvez essa não seja a percepção mais adequada da situação. É possível perceber essa situação como o mal aproveitamento de um atributo que poderia ser trabalhado junto a determinado público para criar 
mais um fator de diferenciação. É claro que esta segunda opção somente se torna possível quando a empresa realizou anteriormente um processo de segmentação, compreendendo o mercado e selecionando efetivamente um determinado segmento para atuar.

Outro ponto que merece consideração com relação a estes concorrentes que estão lançando produtos similares, mas numa versão mais simples e barata, são realmente seus concorrentes. A empresa trabalha num nível relativamente elevado de preços, seus produtos são fabricados em madeira e posssuem uma característica artesanal. Será que ele pode considerar uma empresa que oferece produtos em lona, impressos, como um concorrente direto? Faltam informações para responder este questionamento, mas cabe a reflexão sobre a percepção dos gestores sobre quem são seus concorrentes reais.

A Mitra introduziu recentemente o produto Monte-Car Tunados, que foge das características das linhas de produtos anteriores. O informante justifica a introdução deste novo produto com o objetivo de diversificar a oferta da empresa. O conceito de diversificação trata da introdução de novos produtos em novos mercados (KERIN et al., 2007) e pode ser encarado como uma tentativa da empresa em trabalhar o desenvolvimento de mercados, objetivando o crescimento de suas vendas e lucros.

Resumem-se abaixo as principais considerações sobre o posicionamento de mercado da empresa:

- A empresa não realiza um processo estruturado de planejamento, atuando com base nas reflexões dos proprietários da empresa.

- A empresa está preocupada com a entrada de concorrentes chineses que trabalham produtos de madeira, porém de uma forma industrial em oposição ao processo mais artesanal que a empresa adota.

- A empresa não consegue ter acesso à matéria prima desejada em razão da estrutura de fornecimento de MDF no Brasil e, diante disso, vê-se obrigada a trabalhar com madeira não certificada.

- A empresa percebe o governo, principalmente o Inmetro, como criadores de dificuldades para a aprovação dos brinquedos. 
- A empresa acredita que no Brasil é muito difícil ter a propriedade intelectual das suas criações, sendo normal a cópia e a adaptação de idéias.

- A empresa tem suas possibilidades competitivas restringidas em razão da sua filosofia de negócios, que não permitem processos industrializados, uso de outras matérias primas, como lona e plástico. Mas por outro lado tem realizado iniciativas de diversificação para aumentar a abrangência do negócio.

\subsubsection{Estratégia de posicionamento psicológico}

Seguindo indicações da literatura (DIMINGO, 1989, AAKER, 1998; HOOLEY e SAUNDERS, 1996) e a estrutura de análise utilizada nos outros casos presentes neste trabalho, segue-se com a análise do posicionamento psicológico, por meio da apresentação das estratégias relacionadas a produto, preço, praça/distribuição e promoção/comunicação.

\subsection{Estratégia de posicionamento psicológico - produto}

A Mitra trabalha com 4 linhas de produto, conforme anteriormente mencionado. Eles são produzidos primordialmente com madeira. $\mathrm{O}$ entrevistado percebe que existe algum tipo de preconceito contra os produtos de característica educativa, por acreditar que as pessoas imaginam que esse tipo de produto era destinado a crianças excepcionais. A empresa indica estar trabalhando para acabar com essa percepção equivocada dos consumidores. Ele enfatiza que o produto dele é oriundo da idéia do brinquedo fabricado artesanalmente pelos pais ou avós da criança.

A partir de uma perspectiva cronológica, os proprietários levantam os jogos que fazem parte da história da humanidade. A partir daí, os proprietários analisam o potencial de atratividade do jogo com base nas regras do mesmo. Não existe a preocupação em buscar as opiniões de potenciais consumidores sobre a atratividade do jogo. O informante relata ter mais de 100 jogos já pesquisados e que poderiam fazer parte da linha de produtos da empresa. 
A partir da escolha do jogo a ser produzido, o entrevistado despende esforços para adaptar a estrutura do jogo ao formato livro. Esse processo é trabalhoso, pois às vezes é complicado ajustar o jogo ao formato desejado. O formato livro foi escolhido porque os proprietários da empresa acreditam que as pessoas dão um valor superior ao livro, que fica guardado na estante, em detrimento aos jogos, que terminam guardados em um armário qualquer.

Essa história do livro acho que foi um achado muito grande. Primeiro que era só pra realmente ter alguma coisa fácil de guardar, que não perdesse as peçinhas, porque a dos estojos, sabe aqueles estojinhos, ficava vazio porque são poucas peças que vão dentro. Então a gente acabou descobrindo esse formato. Ai eu acho que a felicidade foi que o livro já tem um certo respeito que o brinquedo não tem. Então você não vê um monte de livro jogado no baú.

A organização lançou recentemente o produto Monte-Car Tunados, visando à diversificação da linha de produtos da empresa. Esse novo brinquedo, também feito de madeira, pretende entregar para a criança um produto semi-acabado, que cria a possibilidade da criança exercitar sua criatividade em um nível que os brinquedos padrão não permitem, por utilizarem tinta guache, que não dá um bom acabamento. Para tanto, a empresa está distribuindo o produto com um lápis de cor aquarelado, que dá um acabamento superior ao produto, como pode ser visto na Ilustração 38.

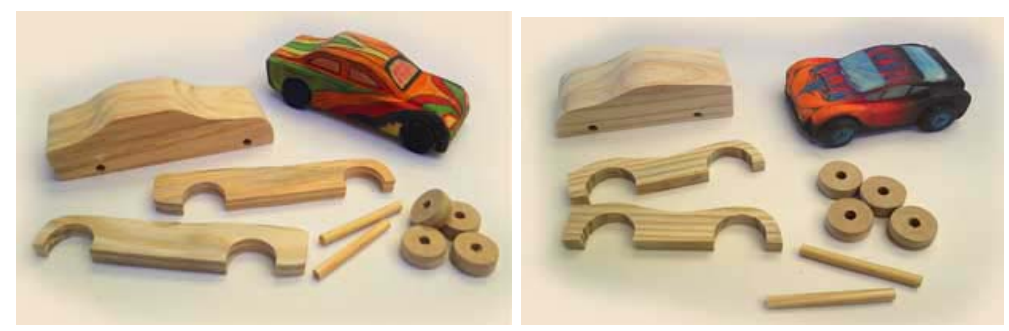

Ilustração 38 - Composição do Monte-Car Tunados FONTE: MITRA; 2008.

O produto também vem acompanhado de uma lixa, que permite que a criança mude de idéia e refaça o trabalho. Em função do conjunto de características do produto, outra entrevistada considera que o produto atende os requisitos desejados pela empresa: "[e]le termina, ele cria, ele interage. Eu acho que são as 3 fases primordiais de um brinquedo educativo". Atualmente estes produtos estão disponíveis apenas em lojas de brinquedos educativos. 
A opção pela elaboração deste tipo de produto está fundamentada na filosofia da empresa, que é influenciada pela entrevistada que é formada em pedagogia Waldorf. Essa escola pedagógica define-se como uma pedagogia que privilegia a vivência antes da teoria (WALDORF, 2008), sendo assim, o brinquedo deve possibilitar a criança a chance de trabalhar suas capacidades, não devendo ser oferecido a esta criança no seu estágio particular de desenvolvimento um brinquedo pronto, que não dá chance da criança trabalhar sua própria criatividade.

De forma geral é possível dizer que a empresa tem trabalhado produtos inovadores em relação aos concorrentes. Esse tipo de estratégia, quando não é copiada pela concorrência em função de falhas no processo de obtenção de patente, pode ser visto como uma vantagem competitiva da empresa, pois o processo produtivo de fabricação destes produtos é exclusivo da empresa.

Abaixo algumas considerações gerais sobre o que foi apresentado:

- A empresa está ampliando seu portifolio de produtos, introduzindo produtos inovadores.

- A empresa busca diferenciar seus produtos por meio do processo produtivo, primordialmente artesanal.

- O processo produtivo da empresa tem uma característica proprietária, criando uma potencial vantagem competitiva.

- Ao desenvolver seus produtos a empresa está sempre atenta aos princípios pedagógicos da escola Waldorf de pedagogia.

\subsection{Estratégia de Posicionamento Psicológico - preço}

A empresa oferece seus produtos ao mercado objetivando com que eles custem entre 40 e 45 reais para o consumidor final. Esse nível de preço é encarado por alguns consumidores como sendo barato e por outros consumidores como sendo caro. A própria empresa indica não compreender totalmente esse tipo de reação do mercado, que é derivada da empresa estar atingindo diferentes segmentos de mercado, que desejam um produto educativo, mas com diferentes rendas disponíveis para o consumo deste tipo de produto. 
O entrevistado analisa a oferta de alguns concorrentes, que oferecem jogos análogos a sua oferta e chega a conclusão de que existem competidores que oferecem produtos similares, como por exemplo os jogos Trilha e Dama, por preços inferiores, beirando os 15 reais. O proprietário diz não conseguir colocar seu produto a um preço mais atrativo em função do processo produtivo. Isso de certa forma impede que a empresa tenha um desempenho melhor nessas categorias onde existe maior concorrência. Como o mesmo não ocorre para a grande maioria dos produtos ofertados pela empresa, o informante sente que tem espaço para crescer.

O preço estabelecido pela empresa pode ser restritivo nos casos onde os competidores oferecem produtos parecidos, mas, ao mesmo tempo, pode ser restritivo por apresentar um preço muito baixo. O entrevistado relata o caso de uma tabacaria que trabalha com presentes de alto nível, onde não foi possível introduzir o produto, pois o proprietário da tabacaria disse que "Eu não vou poder vender aqui porque é muito barato".

Percebe-se, ao analisar de forma mais completa a questão da precificação, que a empresa está oferecendo seu produto para varejistas que atendem segmentos diferentes de mercado (tabacarias, lojas de brinquedos e lojas de brinquedos educativos). Dessa forma, a empresa tem respostas diferenciadas a seu nível de preço. Caso a empresa desenvolvesse alguma forma de pesquisa de segmentação poderia perceber a existência destes diferentes públicos e, conseqüentemente, adequar sua oferta para cada um dos segmentos que freqüenta os diferentes tipos de varejistas, conforme sugerem McDonald e Dunbar (1998).

A seguir algumas considerações gerais sobre o processo de precificação da Mitra:

- Os produtos da empresa, principalmente os jogos, chegam ao mercado por um valor de 40 reais.

- O processo de precificação é realizado apenas com base nas percepções dos donos da empresa. 


\subsection{Estratégia de Posicionamento Psicológico - praça}

A empresa trabalha a distribuição dos seus produtos principalmente por meio de representantes, e aproveita essa oportunidade para divulgá-los junto aos vendedores das lojas. Além desse esforço de distribuição, a empresa também criou um site onde estão apresentados os produtos da empresa, mas não existe a possibilidade de comprar os produtos on-line.

A empresa fornece seus produtos para 10 empresas que trabalham com brinquedos educativos. $\mathrm{O}$ entrevistado indica que existem entre 30 e 50 lojas que trabalham este tipo de produto na Grande São Paulo. De acordo com os entrevistados, as empresas focadas no brinquedo educativo abrem e fecham com uma rapidez muito grande, dificultando o trabalho da empresa. Essas lojas ficam abertas por dois ou três anos no máximo. Poucas permanecem no mercado por muito tempo. Ele dá o exemplo da loja Trenzinho, que já está no mercado há 30 anos. Outra empresa que serve de exemplo é a rede Catavento, que tem várias lojas pela cidade de São Paulo, cada uma de propriedade de um membro da família.

Fora de São Paulo existem poucas lojas que trabalham com este tipo de brinquedo. De acordo com o entrevistado existem cerca de 5 lojas em Florianópolis e cerca de 10 no Rio de Janeiro. Ele também ressalta que existem outras lojas de brinquedos educativos, mas que estão focadas no público infantil, abaixo dos 6 anos. A empresa não pretende entrar nesse ramo de atuação em função de restrições da escola Waldorf de pedagogia, que acredita que determinados tipos de atividades não devem ser propostas às crianças antes de determinada estágio do seu desenvolvimento (WALDORF, 2008).

Abaixo os principais resultados sobre a empresa e a questão da distribuição:

- A distribuição da empresa está focada nas lojas de brinquedos educativos, principalmente na Grande São Paulo.

- As lojas de brinquedos educativos são atendidas por representantes. 


\subsection{Estratégia de posicionamento psicológico - promoção/comunicação}

A empresa trabalha sua comunicação por meio de duas estratégias principais - a primeira delas trata do atendimento aos lojistas. É nesse momento que a empresa vê a chance de convencer os vendedores da loja a trabalharem os produtos da empresa. O informante considera que, se o vendedor não compreender o jogo e suas regras, ele não despenderá esforços para vender o produto. Dessa forma, o empenho da fábrica ao contatar os vendedores das lojas que compram seus produtos está focado no ensinamento das regras de cada um dos jogos. A Mitra também procura passar aos vendedores um pouco da história do jogo, para que isso sirva como apelo de vendas junto ao consumidor.

A companhia oferece ao mercado alguns jogos, como Dama e Trilha, que são oferecidos pela concorrência. O entrevistado afirma que: “[s]ó estou produzindo isso aqui porque gera compra. Muita gente produz, e produz mais barato, bem mais barato que no meu caso. Só estou fazendo isso aqui a pedido dos lojistas, e mesmo assim a coisa está saindo bem”.

Interessante notar as contradições que aparecem no discurso do proprietário. Ele afirma que só produz porque gera compra, a pedido dos lojistas, mas se fosse sua a decisão ele não ofereceria o produto em razão da existência de concorrentes que oferecem o produto mais barato. A única explicação oferecida pelo entrevistado e que pode ajudar a compreender essa situação diz respeito ao trabalho que ele faz divulgando a história dos jogos. Ele considera que os vendedores utilizam o apelo de venda que ele oferece para vender os produtos da concorrência e, portanto, preferiria não vender este tipo de produto. Falta para a empresa uma melhor compreensão do conceito de marketing, de atender o cliente nas suas necessidades.

A segunda estratégia de comunicação utilizada pela empresa consiste no site. Porém, lamenta o entrevistado, o site não recebeu a devida divulgação, não constando ao menos na página da Abrinq, associação da qual a empresa faz parte. O entrevistado relata ter solicitado a atualização dos dados no site da associação, mas sem sucesso. As pessoas chegam até o site da empresa de forma acidental, sem nenhuma interferência das empresas. 


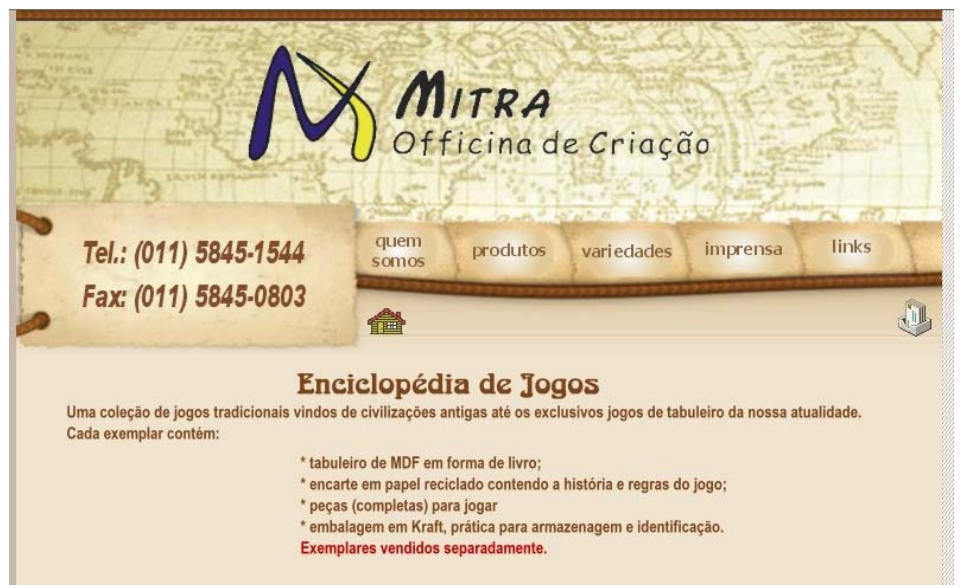

Ilustração 39 - Site da empresa Mitra Officina de Criação FONTE: MITRA; 2008.

O site serve apenas para apresentar os produtos da empresa, não tendo as características necessárias para o comércio eletrônico. Essa poderia ser uma possibilidade interessante para a empresa, mas até o momento não aproveitada e sem previsões para tal.

O proprietário até compreende que, se existissem outras ações de marketing, como propaganda na televisão, as chances de crescimento seriam superiores, mas ele carece dos recursos necessários para tanto.

Apesar de, aparentemente, a empresa estar falhando nos seus esforços de comunicação, essa afirmação pode ser mais bem analisada a partir das considerações de Hooley e Saunders (1996). Os autores indicam que o segmento, para ser atendido de forma individualizada, deve ser alcançável por uma oferta distinta e por uma comunicação diferenciada. Diante disso, cabe a seguinte reflexão - será que o segmento de pessoas que querem comprar produtos educativos é grande o bastante para merecer uma personalização da oferta e da comunicação, ou o esforço de uma comunicação em massa? Este trabalho não apresenta a resposta para essa questão, mas, de qualquer forma, é interessante pensar nessa questão diante das dificuldades encontradas pelos entrevistados e pelas lojas de brinquedos educativos que abrem e fecham rapidamente.

Abaixo as principais considerações sobre o uso da promoção pela Mitra:

- Praticamente toda a comunicação da empresa reside no uso de representantes. 
- A empresa mantém no ar um site com algumas informações sobre os produtos da empresa, mas não existe a oportunidade da compra on-line nem de um maior relacionamento com os consumidores.

\subsubsection{Resumo da análise da Mitra Officina de Criação}

Assim como nos dois casos anteriores termina-se a análise do caso da Mitra com a apresentação da Ilustração 40. 


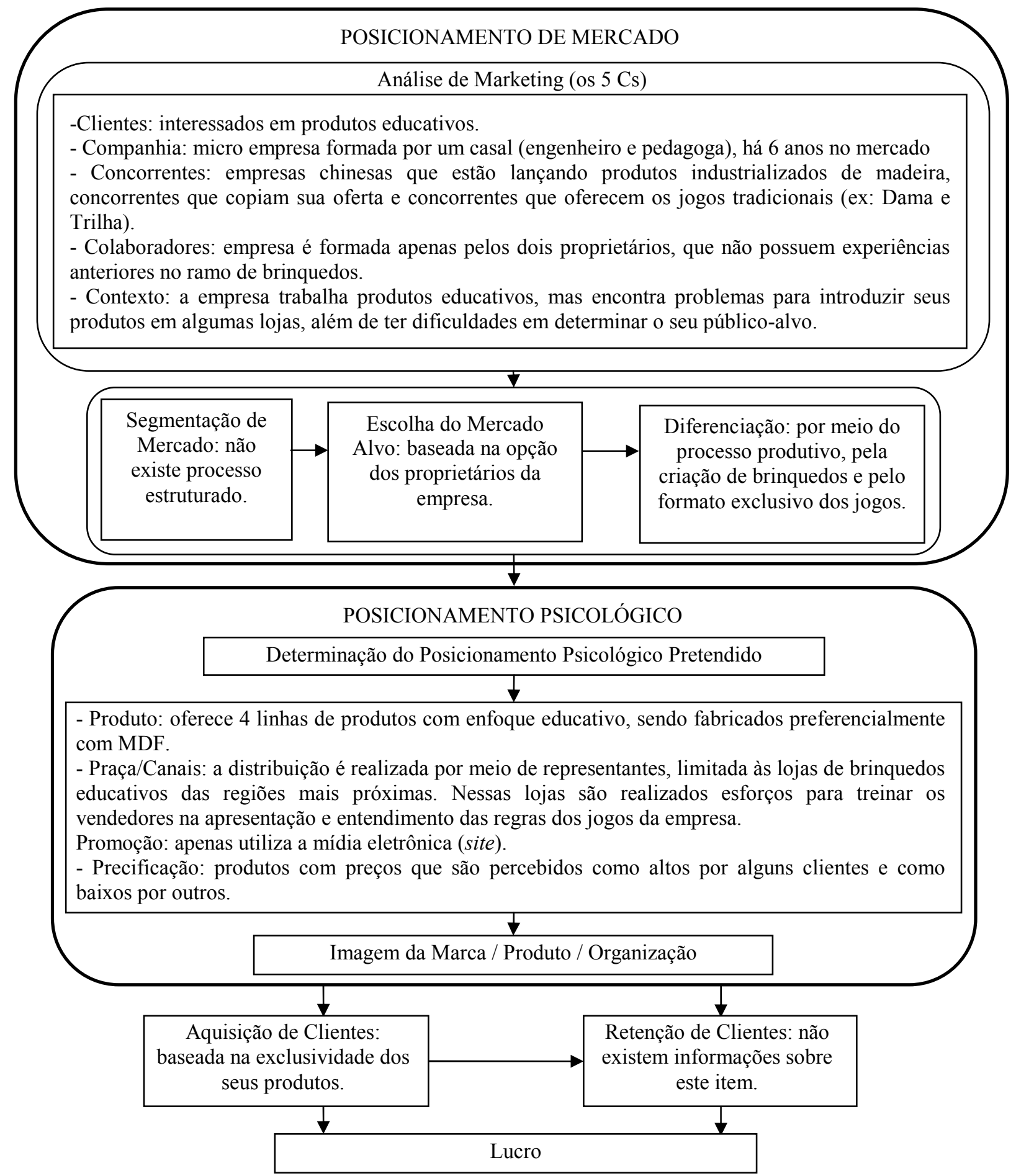

Ilustração 40 - Processo de segmentação e posicionamento da Mitra Officina de Criação Fonte: coleta de dados.

Tendo sido apresentado de forma individual os três casos que compõem a coleta de dados deste trabalho, segue-se com a análise cruzadas dos casos. 


\subsection{Análise cruzada dos casos e a teoria}

Nesta etapa do trabalho, serão construídas as reflexões necessárias sobre os três casos pesquisados. Esta etapa foca a compreensão das semelhanças e diferenças entre as informações fornecidas pelas empresas. O formato desta etapa será similar ao formato que foi utilizado durante as análises individuais de cada caso.

\subsubsection{Considerações iniciais}

As três empresas analisadas surgiram a partir de iniciativas empreendedoras dos seus fundadores. Essa é uma característica inata do setor, de acordo com opiniões dos entrevistados. É somente a partir da abertura de mercados na década de 90 que o setor passou a ser alvo de empresas estrangeiras. A entrada de produtos chineses causou uma série de problemas para as fábricas entrevistadas, mas estes problemas foram superados. Atualmente, é preocupação da Grow a entrada da multinacional Hasbro, a maior fabricante de brinquedos do mundo. O gerente da Grow indica que o mercado de brinquedos internacional se caracteriza por uma forte concentração do setor em torno de poucas e poderosas multinacionais, sendo o Brasil um dos poucos países que ainda tem uma indústria predominantemente nacional.

O parco investimento feito pelas empresas entrevistadas em ações de marketing, tanto de segmentação, como de posicionamento, decorrem da situação apresentada pelo gerente da Grow. Se já existisse uma grande competição, com várias multinacionais operando no país, certamente seriam maiores as preocupações e os esforços da empresa com relação às atividades de marketing. Clancy (2002) considera que o estágio atual do marketing no Brasil corresponde ao estágio do marketing nos Estados Unidos há 15 ou 20 anos atrás. Talvez essa afirmação seja reflexo da situação apresentada pelo gerente da Pica Pau, que afirma não ter concorrentes para a grande maioria de seus produtos. Campomar e Ikeda (2006) concordam com essa afirmação, dizendo que as práticas de primeiro mundo são mais comuns nas filiais de grandes multinacionais, conforme reconhecem os entrevistados. Talvez essa afirmação seja decorrente da situação apresentada pelo gerente da Pica Pau, que afirma não ter concorrentes para a grande maioria de seus produtos. 


\subsubsection{Estratégia de segmentação}

Esta etapa das análises está fundamentada nas principais considerações feitas sobre o processo de segmentação de cada uma das empresas, que estão reproduzidas no quadro Quadro 27, apresentado na página seguinte.

O primeiro passo num processo de segmentação, conforme colocado por Lambin (2000), seria a decisão de macro segmentação, ou seja, a escolha de um segmento de atuação. As três organizações pesquisadas tomaram a decisão de atender o mercado de consumidores interessados em brinquedos de forma não estudada, ao menos não seguindo o método científico apresentado pela literatura. Todas as empresas decidiram abordar esse mercado em função de interesses e predileções de seus fundadores. Esta situação não representa um problema grave do ponto de vista estratégico de marketing, pois é normal que muitas companhias comecem desta forma. $\mathrm{O}$ problema aparece quando as empresas não realizam esforços para compreender as nuances dos segmentos que compõe esse macro-segmento.

Dentre as empresas, a Grow é a única que afirma trabalhar com base em algum tipo de informação, embora sejam fornecidas por terceiros (licenciadores). Tanto a Pica Pau como a Mitra trabalham única e exclusivamente com base no feeling dos seus gestores. A Grow também utiliza este tipo de estratégia de decisão, mas utilizando como base as informações recebidas dos licenciadores. A Mitra é a empresa mais prejudicada por utilizar esse tipo de processo de decisão. Dentro as empresas pesquisadas, a Mitra é a única que acusa a existência de clientes que demonstram estar descontentes com a oferta da empresa. Isso se deve também a pouca experiência da empresa no ramo de brinquedos, enquanto a Grow e a Pica Pau estão há décadas no mercado, a Mitra tem apenas alguns poucos anos de experiência.

Tanto a Grow como a Pica Pau trabalham com base no feeling dos seus gestores, porém agregam as informações coletadas no exterior. Os entrevistados relatam a ida dos altos executivos da empresa para o exterior como uma fonte de idéias para a introdução de novos produtos. Ao invés de recorrer à segmentação para melhor compreender seus consumidores, as empresas preferem copiar as iniciativas de outras empresas que possivelmente estão trabalhando de forma completa o seu processo de marketing. 
Quadro 27 - Comparação teoria e prática - Segmentação

\begin{tabular}{|c|c|c|c|}
\hline Revisão da Literatura & Caso & Estratégia Adotada & Análise \\
\hline \multirow{3}{*}{$\begin{array}{l}\text { - O uso da estratégia de } \\
\text { segmentação gera o nível de } \\
\text { competitividade da empresa } \\
\text { (CAMPOMAR e GIL, 2006) e } \\
\text { permite que ela aloque melhor } \\
\text { os seus recursos (TOLEDO e } \\
\text { HEMZO, 1991; HOOLEY e } \\
\text { SAUNDERS, 1996). } \\
\text { - A opção pela não segmentação } \\
\text { pode ser resultante de questões } \\
\text { econômicas, como a falta de } \\
\text { recursos (BRANDT, 1966; } \\
\text { HOOLEY e SAUNDERS, 1996) } \\
\text { ou pela atuação em um mercado } \\
\text { com características } \\
\text { monopolistas (WEINSTEIN, } \\
\text { 1995). } \\
\text { - A competição, entre empresas } \\
\text { que não segmentam o mercado } \\
\text { se dá pela qualidade de seus } \\
\text { produtos (RICHERS, 1991). } \\
\text { - A infra-estrutura (recursos e } \\
\text { expertise) são potenciais } \\
\text { barreiras à realização do } \\
\text { processo de segmentação } \\
\text { (DIBB, 2005). } \\
\text { - A idade pode ser utilizada } \\
\text { como uma proxy das } \\
\text { capacidades da criança } \\
\text { (processo de socialização e } \\
\text { desenvolvimento cognitivo) } \\
\text { (MCNEAL, 1992; 1999; 2007, } \\
\text { WARD, 1997; PIAGET, 1959; } \\
\text { MONTIGNEAUX, 2003; KAIL, } \\
\text { 2004; DAVIDOFF, 2001; } \\
\text { CARMICHAEL, 1975). }\end{array}$} & $\begin{array}{l}\text { Pica } \\
\text { Pau }\end{array}$ & $\begin{array}{l}\text { - As decisões de segmentação e seleção } \\
\text { do público alvo são tomadas com base } \\
\text { no feeling dos gestores da empresa, que } \\
\text { é suportado pela experiência de } \\
\text { mercado que eles possuem e pela } \\
\text { observação de mercados no exterior. } \\
\text { - A empresa utiliza basicamente duas } \\
\text { variáveis para determinar e } \\
\text { compreender seu público-alvo: idade e } \\
\text { renda. }\end{array}$ & $\begin{array}{l}\text { A empresa não realiza pesquisa de segmentação por não considerar que tal } \\
\text { procedimento é necessário, o que pode ser explicado pela falta de concorrentes } \\
\text { diretos em muitos dos itens que constam do portfolio de produtos da empresa, pelo } \\
\text { baixo número de unidades vendidas em cada uma das linhas de produto e pela } \\
\text { pequena margem obtida na venda de produtos para a classe pretendida. } \\
\text { Essas considerações sinalizam para a falta de recursos disponíveis para a realização } \\
\text { do processo. Apesar da inexistência do processo estruturado a empresa utiliza } \\
\text { corretamente a idade como um sinalizador do perfil dos seus consumidores, a partir } \\
\text { das capacidades que a criança possui nas diferentes etapas que compõem o seu } \\
\text { desenvolvimento. }\end{array}$ \\
\hline & Grow & $\begin{array}{l}\text { - O processo decisório da empresa está } \\
\text { alicerçado na experiência dos seus } \\
\text { gestores, na observação de mercados } \\
\text { estrangeiros e em pesquisas } \\
\text { disponibilizadas pelos licenciadores. } \\
\text { - A empresa utiliza duas variáveis de } \\
\text { segmentação para compreender o } \\
\text { mercado, idade e renda. Além disso } \\
\text { também leva em considerações as } \\
\text { capacidades da criança para } \\
\text { comprar/consumidor seus produtos no } \\
\text { momento da definição do público-alvo. }\end{array}$ & $\begin{array}{l}\text { A empresa justifica sua decisão com base na pequena representatividade de cada } \\
\text { linha de produto e na existência de algumas informações fornecidas pelos } \\
\text { licenciadores. A empresa fundamenta sua capacidade competitiva na diferenciação } \\
\text { dos seus produtos, por meio das licenças adquiridas que lhe dão algum nível de } \\
\text { diferenciação e exclusividade no mercado. O uso de licenças está atrelado ao } \\
\text { processo de socialização da criança, que passa a se interessar por personagens } \\
\text { presentes na mídia, sob influência dos seus pares e da própria mídia. A idade é } \\
\text { considerada pela empresa como uma das formas de compreender as capacidades do } \\
\text { seu consumidor na compra e utilização dos produtos oferecidos. }\end{array}$ \\
\hline & Mitra & $\begin{array}{l}\text { - A empresa não conduz atividades de } \\
\text { pesquisa para segmentar o seu } \\
\text { mercado. } \\
\text { - A empresa aposta na elaboração de } \\
\text { um produto de qualidade para gerar } \\
\text { apelo junto aos consumidores. } \\
\text { - A empresa encontra-se num estágio } \\
\text { de macro-segmentação, tendo apenas } \\
\text { definido de forma abrangente o seu } \\
\text { mercado de atuação. } \\
\text { - A empresa define a idade adequada } \\
\text { para o brinquedo com base nas } \\
\text { questões relativas ao processo de } \\
\text { desenvolvimento cognitivo da criança. }\end{array}$ & $\begin{array}{l}\text { Não existe um processo estruturado de segmentação de mercado. A empresa apenas } \\
\text { definiu que iria trabalhar com brinquedos educativos, partindo dessa decisão para a } \\
\text { criação, desenvolvimento e comercialização de seus produtos. A empresa almeja } \\
\text { entregar um produto de qualidade que possa atrair consumidores, mas percebe que } \\
\text { existem confusões na percepção dos clientes sobre o produto, como sendo muito } \\
\text { caro ou muito barato. Todo o processo da empresa está fundamentado nos } \\
\text { princípios da pedagogia Waldorf, que direciona a empresa para o desenvolvimento } \\
\text { de produtos que têm um diferencial frente às outras opções de brinquedos por se } \\
\text { tratar de um brinquedo de caráter educativo, porém limita algumas alternativas } \\
\text { estratégicas, como por exemplo, o uso de uma alternativa de matéria prima mais } \\
\text { barata. }\end{array}$ \\
\hline
\end{tabular}

Fonte: Elaborado pelo autor com base no referencial teórico e na coleta de dados. 
Tanto a Pica Pau quanto a Grow recorrem ao mesmo argumento para justificar a inexistência de pesquisas de segmentação. As empresas apresentam muitas linhas de produto, que individualmente são pouco representativas no computo geral da empresa. Esse fator torna impraticável financeiramente realizar pesquisas de segmentação. Talvez fosse possível realizar pesquisas mais abrangentes, que englobassem consumidores das diferentes linhas de produtos.

O processo de segmentação não é necessário para toda e qualquer fábrica e também não é necessário para que se conduza o processo de posicionamento. Uma empresa pode realizar todas as suas atividades de posicionamento, principalmente àquelas relacionadas ao composto de marketing, sem ter realizado o processo de segmentação. A segmentação por si só não faz sentido para a empresa, o seu significado deriva do seu uso. Sendo assim, mesmo sem realizar o processo de segmentação conforme descrito pela literatura, a empresa pode conduzir o seu posicionamento. É claro que quanto mais planejado e baseado em informações sobre o mercado, melhor será o resultado do posicionamento, mas isso é uma decisão que envolve os gestores da empresa.

Mesmo sem ter conduzido o processo de segmentação as empresas Grow e Pica Pau têm clara noção que seus clientes podem ser identificados pela idade e pela renda. A Pica Pau é mais focada que a Grow neste sentido, pois aborda apenas o segmento denominado popular. Já a Grow trabalha tanto o mercado mais popular como os mercados premium. A empresa Mitra enfrenta problemas em relação à definição do seu público-alvo, pois percebe que existem níveis diferenciados de aceitação dos seus produtos, tanto da parte dos consumidores, como de parte do canal de distribuição.

As empresas Grow e Mitra trabalham, ainda que de forma não estruturada, os conceitos de desenvolvimento cognitivo e social para indicar o segmento adequado para seus brinquedos. As empresas procuram compreender as capacidades dos seus clientes para identificar a faixa etária correspondente que teria condições psico-sociais de utilizar plenamente seus produtos. Essa preocupação decorre da característica dos brinquedos lançados. Ambas as empresas trabalham produtos de tabuleiro que exigem uma capacidade maior da criança. A empresa Pica Pau não tem, em seu portfolio de produtos, itens com essa característica e, sendo assim, identifica a variável 
renda como a mais significativa para definir seu público, sendo que a idade aparece em segundo plano.

\subsubsection{Posicionamento de mercado}

No Quadro 28, localizado na próxima página, são apresentados os principais resultados referentes ao processo de posicionamento de mercado das empresas estudadas. A partir dessas informações é conduzida a análise apresentada.

Em um primeiro momento identifica-se que as empresas sentiram a influência da entrada de produtos importados da China no mercado. Contudo, reconhecem os entrevistados que esta etapa foi transposta e que, no atual momento, os players $^{34}$ do mercado não têm mais essa preocupação com este tipo de produto.

Existe uma percepção de que o consumidor nacional compreendeu que parte dos brinquedos importados da China apresenta restrições relacionadas ao seu nível de qualidade. Dados apresentados pela Abrinq indicam o crescimento exponencial das importações de brinquedos, sendo que o faturamento, com base em produtos importados, quintuplicou nos últimos cinco anos, enquanto o faturamento da produção nacional teve um crescimento de aproximadamente $30 \%$. Os dados da Abrinq não permitem compreender se esse crescimento do brinquedo importado é decorrente de produtos chineses ou não, mas, de qualquer forma, percebe-se que o mercado nacional está sendo sobrepujado de forma significativa pelos importados.

A empresa Grow identifica que o mercado internacional de brinquedos é dominado por alguns poucos concorrentes poderosos, como a Hasbro e a Mattel. São poucos os países em que a indústria nacional sobrevive. O padrão é a consolidação da indústria com base nesses fabricantes estrangeiros. As empresas Mitra e Pica Pau não se preocupam tanto com essa questão, pois estão focadas em segmentos mais específicos de mercado, o de brinquedos educativos e o popular, respectivamente. Já a Grow, por atuar predominantemente por meio de licenciamentos, atendendo parcelas da classe A e B, entende que essa concorrência (Mattel e Hasbro) terá impactos significativos no futuro.

\footnotetext{
${ }^{34}$ Expressão em inglês adaptada à língua portuguesa que tem como significado participantes do mercado
} 
Quadro 28 - Comparação teoria e prática - posicionamento de mercado

\begin{tabular}{|c|c|c|c|}
\hline $\begin{array}{l}\text { Revisão da } \\
\text { Literatura }\end{array}$ & Caso & Estratégia Adotada & Análise \\
\hline \multirow{3}{*}{$\begin{array}{l}\text { - O } \\
\text { posicionamento } \\
\text { de mercado deriva } \\
\text { do processo de } \\
\text { planejamento da } \\
\text { empresa e sinaliza } \\
\text { o curso de ação } \\
\text { pretendido } \\
\text { (ACHENBAUN, } \\
\text { 1974). } \\
\text { - A definição do } \\
\text { posicionamento } \\
\text { de mercado } \\
\text { envolve a } \\
\text { compreensão da } \\
\text { dinâmica do } \\
\text { mercado, visando } \\
\text { identificar lacunas } \\
\text { onde a empresa } \\
\text { pode competir de } \\
\text { forma mais efetiva } \\
\text { (DIMINGO, } \\
\text { 1981; TOLEDO e } \\
\text { HEMZO, 1991). } \\
\text { - O } \\
\text { posicionamento } \\
\text { deve ser } \\
\text { estabelecido com } \\
\text { base em vantagens } \\
\text { competitivas } \\
\text { sustentáveis } \\
\text { (DOYLE e } \\
\text { SAUNDERS, } \\
\text { 1985). }\end{array}$} & $\begin{array}{l}\text { Pica } \\
\text { Pau }\end{array}$ & $\begin{array}{l}\text { - A empresa não realiza nenhum processo estruturado de planejamento, } \\
\text { baseando suas decisões no feeling dos gestores. } \\
\text { - A empresa acredita que apenas uma pequena parcela dos seus produtos } \\
\text { enfrenta concorrentes diretos, e que isso faz com que a empresa não } \\
\text { tenha muitos problemas com a concorrência. } \\
\text { - A empresa está focada no segmento popular, mas está passando por um } \\
\text { processo de aumento do valor oferecido nos seus produtos. Essa } \\
\text { estratégia visa fazer parte do sortimento de varejistas mais renomados, } \\
\text { como Rihappy e Alo Bebê. }\end{array}$ & $\begin{array}{l}\text { Apesar de não existir um processo estruturado de planejamento } \\
\text { estratégico do posicionamento pretendido, a empresa caminha } \\
\text { no sentido de adotar algumas das sugestões da literatura com } \\
\text { relação ao aproveitamento de vantagens competitivas } \\
\text { sustentáveis que a empresa possui, principalmente em relação ao } \\
\text { baixo custo. A empresa tem uma percepção equivocada da } \\
\text { concorrência que enfrenta no mercado, imaginando que por não } \\
\text { existirem produtos similares ao que comercializa que esses } \\
\text { produtos estão totalmente isentos do impacto concorrencial. }\end{array}$ \\
\hline & Grow & $\begin{array}{l}\text { - A empresa não realiza nenhum processo estruturado de planejamento, } \\
\text { baseando suas decisões no feeling dos gestores. } \\
\text { - A empresa entende que o mercado passará por um processo de grande } \\
\text { mudança nos próximos anos com a entrada do maior fabricante mundial } \\
\text { de brinquedos, a Hasbro. } \\
\text { - A empresa avalia que produtos baseados em licenças de personagens de } \\
\text { sucesso são garantia de vendas. } \\
\text { - A empresa criou a oportunidade de desenvolver economias na produção } \\
\text { ao ter uma gráfica própria, gerando assim uma vantagem competitiva } \\
\text { sobre seus concorrentes. }\end{array}$ & $\begin{array}{l}\text { A empresa, mesmo sem ter um planejamento estruturado, } \\
\text { apresenta uma série de iniciativas que buscam trazer } \\
\text { competitividade para a empresa, como o processo de } \\
\text { licenciamento e as parcerias com outras empresas. Além disso, a } \\
\text { empresa também utiliza o seu processo produtivo como fonte de } \\
\text { vantagem competitiva. Percebe-se de forma geral que a empresa } \\
\text { apresenta uma preocupação com o seu entorno concorrencial, } \\
\text { preocupando-se com a dinâmica das mudanças que ocorrerão no } \\
\text { mercado. }\end{array}$ \\
\hline & Mitı & $\begin{array}{l}\text { - A empresa não realiza um processo estruturado de planejamento, } \\
\text { atuando com base nas reflexões dos proprietários. } \\
\text { - A empresa está preocupada com a entrada de concorrentes chineses que } \\
\text { trabalham produtos de madeira, porém de uma forma industrial em } \\
\text { oposição ao processo mais artesanal que a empresa adota. } \\
\text { - A empresa não consegue ter acesso à matéria prima desejada em razão } \\
\text { da estrutura de fornecimento de MDF no Brasil e, diante disso, vê-se } \\
\text { obrigada a trabalhar com madeira não certificada. } \\
\text { - A empresa percebe o governo, principalmente o Inmetro, como } \\
\text { criadores de dificuldades para a aprovação dos brinquedos. } \\
\text { - A empresa acredita que no Brasil é muito difícil ter a propriedade } \\
\text { intelectual das suas criações, sendo normal a cópia /adaptação de idéias. } \\
\text { - A empresa tem suas possibilidades competitivas restringidas em razão } \\
\text { da sua filosofia de negócios, ms por outro lado tem realizado iniciativas } \\
\text { de diversificação para aumentar a abrangência do negócio. }\end{array}$ & $\begin{array}{l}\text { Apesar de trabalhar uma oferta diferenciada para o seu público, } \\
\text { a empresa reconhece que em alguns casos é possível que seus } \\
\text { produtos sejam copiados pela concorrência. A empresa tem uma } \\
\text { percepção bastante equivocada dos seus concorrentes, pois os } \\
\text { produtos similares existentes no mercado são oferecidos numa } \\
\text { versão mais básica, simples e barata. A empresa também } \\
\text { apresenta problemas para realizar o seu processo produtivo de } \\
\text { acordo com o planejado (fornecimento de MDF). A } \\
\text { fundamentação filosófica da empresa não pode ser diretamente } \\
\text { desmerecida como fator que diminui a competitividade da } \\
\text { empresa, mas sim como um fator de diferenciação mal } \\
\text { aproveitado junto a determinado segmento do mercado que } \\
\text { poderia perceber um atrativo nesta filosofia. }\end{array}$ \\
\hline
\end{tabular}

Fonte: Elaborado pelo autor com base no referencial teórico e na coleta de dados. 
A primeira consideração que merece ser salienta diz respeito à falta de um processo estruturado de posicionamento de mercado. Todas as empresas trabalham basicamente a capacidade de seus gestores. A Grow e a Pica Pau têm no seu quadro de funcionários experientes profissionais que lhes permitem ter uma estratégia e uma percepção das dinâmicas de mercado mais apuradas. Já a Mitra sofre com a falta de experiência dos seus proprietários, mas mesmo assim está presente no mercado por um tempo maior do que a grande maioria das micro e pequenas empresas que abrem as portas diariamente. Como será visto nas considereções a seguir, mesmo com essa "informalidade" no processo decisório, as empresas conseguem um determinado nível de compreensão do mercado que lhes permite manter um bom nível de competitividade e permanência no mercado. É importante esclarer que no longo prazo, com a entrada de empresas mais estruturadas no mercado, essa situação dificilmente se manterá.

As três empresas pesquisadas apresentam estratégias que permitem estabelecer algum nível de competitividade de mercado. A Grow trabalha como vantagem competitiva a sua capacidade de estabelecer parcerias com outras empresas do ramo (lançamento de produtos em parceria e licenciamentos) e a existência de uma gráfica própria para justificar sua capacidade no mercado (economias de custo). A Pica Pau identifica que, devido ao seu posicionamento de baixo custo, existem poucos concorrentes no mercado para os seus produtos. Em razão disso, a empresa se sente tranqüila para acreditar que continuará tendo um bom desempenho a longo prazo. Essa crença deriva também da experiência acumulada pelos gestores da empresa, que estão trabalhando no setor de brinquedos há décadas. A Mitra tem sua competitividade alicerçada no desenvolvimento de produtos únicos num segmento bastante especifico - brinquedos educativos.

Percebe-se que as três empresas têm algum fator que dá sustentação a sua estratégia competitiva. A Grow e a Pica Pau têm essas competências bastante claras, já a Mitra apresenta algumas dificuldades para encontrar o segmento adequado para seus produtos. Atividades de segmentação teriam sido bastante úteis para as três empresas, pois lhes dariam um entendimento mais produndo sobre a composição do mercado e dos desejos e necessidades mais específicos dos segmentos que compõem o mercado atendido. 
As empresas Mitra e Pica Pau têm buscado o desenvolvimento de mercados por meio da introdução de novas linhas de produtos e atendendo novos segmentos de mercado. Neste sentido, a Pica Pau está introduzindo linhas de produtos que buscam permitir a entrada da empresa em redes varejistas de brinquedos, onde é possível oferecer produtos com um valor agregado superior. Apesar disso, a empresa não pretende em nenhum momento ir para o outro extremo do mercado, o setor premium. Já a Mitra, ainda que dentro do setor de brinquedos educativos, está lançando novos produtos, além daqueles existentes na linha de tabuleiros e desafios.

A Grow é a empresa que trabalha de forma mais significativa o lançamento de novos produtos, principalmente em razão do uso da estratégia de licenciamento. Esse tipo de estratégia tem vida curta, pois a empresa identifica que um licenciamento de sucesso dura cerca de um ou dois anos no máximo. Após este período, a empresa se vê obrigada a reformular sua estratégia por meio da compra de novas licenças, com personagens mais atuais. $\mathrm{O}$ uso deste tipo de estratégia será abalado pela entrada da multinacional Hasbro no mercado. A entrada dessa multinacional também trouxe outros prejuízos para a empresa, relacionados a alguns jogos que eram lançados em parceria com essa empresa e que agora serão lançados pela própria Hasbro.

\subsubsection{Posicionamento psicológico}

Este tópico inicia a análise cruzada dos casos em relação às atividades de posicionamento psicológico das empresas estudadas. Utilizou-se como estrutura de análise o composto de marketing, pois é o mesmo que gera os estímulos percebidos pelo consumidor para formar o posicionamento pretendido pela empresa. A análise termina com o item promoção, que é percebido por muitos autores como sendo o item mais importante no posicionamento psicológico.

\subsubsection{Posicionamento psicológico - produto}

Tomando como base o Quadro 29, apresentado na pagina seguinte, são elaboradas as considerações e análises relacionadas às empresas e a forma como gerenciam o item Produto do composto de marketing. 
Quadro 29 - Comparação teoria e prática - posicionamento psicológico - produto

\begin{tabular}{|c|c|c|c|}
\hline Revisão da Literatura & Caso & Estratégia Adotada & Análise \\
\hline \multirow{3}{*}{$\begin{array}{l}\text { - Produtos inovadores } \\
\text { apresentam maiores } \\
\text { níveis de risco, já a cópia } \\
\text { ou imitação de produtos } \\
\text { existentes minimiza esse } \\
\text { risco (MCNEAL, 1992). } \\
\text { - Produtos inovadores } \\
\text { tem um potencial de } \\
\text { sucesso financeiro maior } \\
\text { (MCNEAL, 1992). } \\
\text { - Os produtos } \\
\text { desenvolvidos para as } \\
\text { crianças devem trazer ao } \\
\text { menos algum fator } \\
\text { inovador para ter um } \\
\text { apelo junto ao público- } \\
\text { alvo (VECCHIO, 2002), } \\
\text { - A empresa deve atentar } \\
\text { para os centros de } \\
\text { interesse das crianças ao } \\
\text { desenvolver os seus } \\
\text { produtos (Montigneaux, } \\
\text { 2003). } \\
\text { - Ao elaborar o design do } \\
\text { produto as empresas } \\
\text { devem atentar para três } \\
\text { fatores: desenvolvimento } \\
\text { cognitivo e social, } \\
\text { habilidades sociais e } \\
\text { desenvolvimento físico e } \\
\text { motor (FISHEL, 2001). }\end{array}$} & $\begin{array}{l}\text { Pica } \\
\text { Pau }\end{array}$ & $\begin{array}{l}\text { - Com relação ao processo de desenvolvimento de } \\
\text { produto percebe-se que a empresa opta pela adaptação de } \\
\text { produtos já existentes em outros mercados, não } \\
\text { desenvolvendo produtos realmente inovadores. } \\
\text { - Ademais, é possível compreender que existe uma } \\
\text { preocupação com a qualidade do produto para não gerar } \\
\text { decepções junto ao seu mercado. A empresa trabalha a } \\
\text { ligação das crianças com personagens famosos lançando } \\
\text { produtos inspirados em personagens variados. } \\
\text { - A empresa atenta para o nível de desenvolvimento do } \\
\text { seu público-alvo no momento do desenvolvimento do } \\
\text { produto, procurando não oferecer nenhum tipo de risco } \\
\text { para seus consumidores. }\end{array}$ & $\begin{array}{l}\text { A opção por desenvolver produtos com base na imitação é potencialmente } \\
\text { menos arriscada, mas por outro lado limita as possibilidades de sucesso da } \\
\text { empresa, as quais seriam maiores com o lançamento de produtos } \\
\text { inovadores. A preocupação com um determinado nível de qualidade deve- } \\
\text { se a dependência da empresa do boca-a-boca como ferramenta de } \\
\text { comunicação, haja vista que a empresa realiza poucas s ações } \\
\text { promocionais. Ao trabalhar as questões relacionadas ao nível de } \\
\text { desenvolvimento da criança no momento do desenvolvimento de novos } \\
\text { produtos, a empresa demonstra mais uma vez a preocupação com o boca-a- } \\
\text { boca positivo como ferramenta de comunicação da empresa. }\end{array}$ \\
\hline & Grow & $\begin{array}{l}\text { - O processo de desenvolvimento de produtos é realizado } \\
\text { de inúmeras formas pela empresa: jogos já existentes que } \\
\text { são atualizados; jogos trazidos do exterior, pela própria } \\
\text { Grow ou em parceria com um fabricante estrangeiro; } \\
\text { inovações trazidas por inventores; e encomendas } \\
\text { realizadas para inventores. } \\
\text { - A empresa faz largo uso da estratégia de licenciamento, } \\
\text { procurando sempre trazer personagens da moda. }\end{array}$ & $\begin{array}{l}\text { A empresa trabalha tanto a inovação como a imitação, com um forte uso da } \\
\text { estratégia de licenciamento. Percebe-se que a empresa tem uma ampla } \\
\text { gama de fontes de novidades, o que tem garantido sua presença no } \\
\text { mercado e constitui uma fonte de vantagem competitiva para o combate } \\
\text { junto aos novos competidores do mercado. O uso de personagens } \\
\text { licenciados a necessidade da criança de se sentir parte de determinado } \\
\text { grupo de pares. }\end{array}$ \\
\hline & Mitra & $\begin{array}{l}\text { - A empresa está ampliando seu portifolio de produtos, } \\
\text { introduzindo produtos inovadores. } \\
\text { - A empresa busca diferenciar seus produtos por meio do } \\
\text { processo produtivo, primordialmente artesanal. } \\
\text { - O processo produtivo da empresa tem uma } \\
\text { característica proprietária, criando uma potencial } \\
\text { vantagem competitiva. } \\
\text { - ao desenvolver seus produtos a empresa está sempre } \\
\text { atenta aos princípios pedagógicos da escola Waldorf de } \\
\text { pedagogia. }\end{array}$ & $\begin{array}{l}\text { A empresa está ampliando, ainda que de forma tímida, o seu portifolio de } \\
\text { produtos. Essa iniciativa visa diminuir a vulnerabilidade da empresa a } \\
\text { oscilações do mercado. Esses produtos (brinquedos educativos) têm uma } \\
\text { característica inovadora, pois apresentam um formato diferenciado e tipos } \\
\text { de jogos que não estão disponíveis no mercado. A empresa até pensa em } \\
\text { não oferecer produtos que têm concorrentes, mas não o faz a pedido dos } \\
\text { lojistas. Com a produção da empresa é realizada por meio do maquinário } \\
\text { desenvolvido especialmente pelo proprietário é possível considerar que } \\
\text { isso representa uma vantagem competitiva frente à concorrência. A } \\
\text { empresa está fundamentada nos princípios pedagógicos da escola Waldorf } \\
\text { de pedagogia, restringindo assim a entrada em alguns mercados e } \\
\text { direcionado a forma como cria e apresenta seus produtos. }\end{array}$ \\
\hline
\end{tabular}

Fonte: Elaborado pelo autor com base no referencial teórico e na coleta de dados. 
As três empresas trabalham um processo de introdução de novos produtos baseado principalmente nos seus gestores. O uso de informações sobre as necessidades e desejos do público-alvo para direcionar o desenvolvimento de novos produtos é escasso. Apenas a Grow tem acesso a algumas informações oferecidas pelos licenciadores para tomada de decisão. As outras empresas fundamentam suas decisões nas opiniões dos gestores da empresa.

Tanto a Grow como a Pica Pau informam que existe uma tentativa de captar as tendências do mercado e coletar novas idéias por meio de viagens ao exterior e participação em feiras de brinquedo internacionais. Os altos executivos da empresa fazem viagens para os Estados Unidos, Europa e Japão para identificar as novidades do setor. Com base nessas informações, os gerentes e diretores da empresa se reúnem para definir as idéias para os novos produtos. Existe uma premissa por detrás deste tipo de atividade, que considera que o consumidor destes países tem características similares aos consumidores nacionais. A experiência das empresas têm demonstrado que esse tipo de estratégia tem tido boa receptividade no mercado.

No caso particular da Grow, esse tipo de estratégia também se alicerça no fenômeno dos sucessos globais de determinados personagens que estão sendo lançados em filmes e seriados televisivos, o que para a empresa tem se demonstrado uma estratégia adequada que tem gerado os retornos esperados. A Pica Pau utilizou este tipo de estratégia durante algum tempo, mas começou a enfrentar dificuldades para obter a permissão para lançar os produtos licenciados. Essa situação fez com que a empresa desistisse deste tipo de ação.

Ao serem questionadas se utilizam apelos nacionais nos seus lançamentos, as empresas indicaram que isso é raro, quase nunca utilizado. É possível imaginar que existam alguns segmentos de consumidores nacionais que estariam interessados em produtos que abordassem de alguma forma temáticas mais ligadas ao próprio pais, mas este tipo de informação só aparecerá quando as empresas dediquem esforços reais para segmentar o mercado, compreendendo melhor a composição do mesmo, com suas peculiaridades.

Das três empresas, a Grow é a que apresenta um processo mais elaborado de criação de novos produtos, pois não só utiliza a questão da adaptação de produtos, mas também tenta desenvolver 
novidades com base em inventores nacionais, ainda que de forma tímida. Além disso, a empresa tem conseguido também exportar a idéia de alguns produtos nacionais para o exterior, trilhando um caminho inverso ao normal do mercado. A empresa também demonstra sua compreensão do mercado infantil quando sinaliza o uso de crianças com idades superiores ao público-alvo nas suas propagandas.

A Mitra, apesar de ser uma pequena empresa, tem trabalhado de forma constante a introdução de produtos que apresentam um diferencial em relação às outras opções existentes no mercado. A empresa, talvez sem ter o perfeito conhecimento disso, está se especializando num tipo de produto especifico - o brinquedo educativo. A empresa fundamenta suas estratégias na filosofia da Escola Waldorf, o que pode ser entendido como a criação de uma oferta bastante diferenciada, a qual pode ter apelo junto a determinado segmento que ainda não foi claramente compreendido pela empresa em razão da falta de informações.

Por fim, identifica-se que as empresas, de forma não consciente, utilizam as considerações colocadas pela literatura que aborda o desenvolvimento da criança, ou seja, as empresas trabalham o desenvolvimento de produto com preocupações referentes à capacidade da criança em consumir o mesmo, em saber lidar com as características do produto e na segurança da criança quando consumindo o produto.

\subsubsection{Posicionamento psicológico - preço}

Neste tópico é abordado o item Preço do composto de marketing. Para tanto, é apresentado o Quadro 30 com as principais considerações das empresas pesquisadas, para posteriormente trazer uma análise comparativa. 
Quadro 30 - Comparação teoria e prática - posicionamento psicológico - preço

\begin{tabular}{|c|c|c|c|}
\hline Revisão da Literatura & Caso & Estratégia Adotada & Análise \\
\hline \multirow{3}{*}{$\begin{array}{l}\text { - A empresa deveria começar o seu } \\
\text { processo de precificação com base na } \\
\text { percepção dos consumidores sobre } \\
\text { quanto vale o produto e quanto estão } \\
\text { dispostos a pagar (NAGLE e HOLDEN, } \\
\text { 2005). } \\
\text { - As crianças, principalmente as mais } \\
\text { velhas tem uma percepção negativa do } \\
\text { preço de forma geral (MCNEAL, 1999). } \\
\text { - O entendimento do preço começa aos } 5 \\
\text { anos (MCNEAL, 1999). } \\
\text { - Até } 8 \text { ou 9 anos as crianças oriundas da } \\
\text { alta renda não percebem claramente a } \\
\text { função do preço no momento de } \\
\text { consumo (VELOSO e HILDEBRAND, } \\
\text { 2007). } \\
\text { - Dados coletados nos EUA indicam que } \\
\text { a criança economizam dinheiro para } \\
\text { compra de produtos mais caros } \\
\text { (MCNEAL, 1999) } \\
\text { - O processo de compreensão do fator } \\
\text { preço no momento de consumo é } \\
\text { decorrente do nível de desenvolvimento } \\
\text { socialização da criança consumidora } \\
\text { (STAMPFL et al., 1978; MOSCHIS e } \\
\text { MOORE, 1978; e STEPHENS e } \\
\text { MOORE, 1975). }\end{array}$} & $\begin{array}{l}\text { Pica } \\
\text { Pau }\end{array}$ & $\begin{array}{l}\text { - A empresa tem um processo de determinação de preço que } \\
\text { começa com a identificação de um preço-alvo em } \\
\text { consonância com as necessidades do público-alvo. } \\
\text { - A empresa tenta compreender as percepções de preço dos } \\
\text { consumidores, mas de forma não estruturada. } \\
\text { - De forma geral os preços são baixos, focados na aceitação } \\
\text { junto ao público mais popular. }\end{array}$ & $\begin{array}{l}\text { - Com relação ao processo de precificação identifica- } \\
\text { se uma grande preocupação com o desenvolvimento } \\
\text { de produtos com um preço realmente acessível para o } \\
\text { mercado popular, utilizando um processo de } \\
\text { desenvolvimento de produto que começa com um } \\
\text { preço máximo (idealizado pelos gestores com base no } \\
\text { feeling) que deve ser respeitado pela área produtiva } \\
\text { da empresa. }\end{array}$ \\
\hline & Grow & $\begin{array}{l}\text { - No que se refere ao processo de precificação, dois fatores } \\
\text { influenciam as decisões da empresa, são eles: (a) os valores } \\
\text { pagos para obter a permissão para lançar determinado } \\
\text { produto com um personagem e que tem um impacto } \\
\text { negativo no processo; (b) o uso de uma gráfica própria que } \\
\text { proporciona economias para a empresa em relação a } \\
\text { concorrentes que não possuem essa capacidade. } \\
\text { - O processo de precificação é conduzido com base nas } \\
\text { informações fornecidas pelas empresas de licenciamento e } \\
\text { na experiência de mercado dos gestores. } \\
\text { - A empresa apresenta desde produtos com preços populares, } \\
\text { até produtos de maior valor agregado e preços superiores. }\end{array}$ & $\begin{array}{l}\text { - A empresa apresenta uma estratégia de precificação } \\
\text { que é amplamente impactada por dois fatores } \\
\text { principais (licenciamento e gráfica). A partir desses } \\
\text { fatores são desenvolvidos níveis de preços variados. } \\
\text { - As informações oferecidas pelos licenciadores } \\
\text { formam uma das fontes de informação para a tomada } \\
\text { de decisão na empresa, porém essas pesquisas têm as } \\
\text { limitações inerentes ao uso de dados secundários. }\end{array}$ \\
\hline & Mitra & $\begin{array}{l}\text { - Os produtos da empresa, principalmente os jogos, chegam } \\
\text { ao mercado por um valor de } 40 \text { reais. } \\
\text { - O processo de precificação é realizado apenas com base } \\
\text { nas percepções dos donos da empresa. }\end{array}$ & $\begin{array}{l}\text { - Os produtos da empresa chegam ao consumidor } \\
\text { final por cerca de } 40 \text { reais. Esse valor é considerado } \\
\text { por alguns segmentos como sendo muito caro, e por } \\
\text { outros segmentos como sendo muito barato. A } \\
\text { empresa determinou uma política de precificação que } \\
\text { não compreende as diferenças entre os diferentes } \\
\text { segmentos que compõem o mercado de brinquedos } \\
\text { educativos. }\end{array}$ \\
\hline
\end{tabular}

Fonte: Elaborado pelo autor com base no referencial teórico e na coleta de dados. 
As três empresas apontam, de alguma forma, critérios de custo para balizar o processo de construção do preço. A Grow indica que seu processo é influenciado pelos valores pagos no licenciamento de produtos (aumentando o custo) e pela existência de uma gráfica própria (diminuição de custo) que permite a economia de custos em algumas linhas de produtos, não todas.

Já a Pica Pau indica que existe uma grande preocupação em criar produtos que cheguem ao consumidor final por preços bastante baixos. Para tanto, a companhia relata conduzir o processo de criação de um novo produto por meio de um custo alvo, que deve ser atingido pela área produtiva, sob risco de descontinuação do processo. Essa preocupação da empresa deriva da sua definição do segmento-alvo, ou seja, popular. Essa estratégia é altamente recomendada, mas não está sendo utilizada da forma mais correta pela empresa. A empresa não tem informações sobre as expectativas dos consumidores para ter o correto nível de preço que deve direcionar o processo de precificação.

A Mitra é a que apresenta maiores dificuldades com seu processo de precificação, pois recebe informações do mercado (consumidores e canal de distribuição) que indicam a existência de problemas na estratégia da empresa. A fábrica trabalha seu preço a partir do custo de produção. $\mathrm{O}$ processo produtivo da empresa é basicamente fundamentado nas capacidades de um dos proprietários da empresa na criação do maquinário necessário para produzir. Em razão desse caráter artesanal da produção, seu custo é bastante alto. Dessa forma, a empresa se vê obrigada a colocar no mercado um produto com preço de venda ao consumidor final cercando os 40 reais. Isso faz com que alguns consumidores considerem o produto caro, e outros barato. Fica clara a necessidade de um processo de segmentação para identificar melhor as características do mercado, para que a empresa pudesse focar seus esforços naquele segmento mais atrativo, ou criar ofertas diferenciadas para cada segmento. 


\subsubsection{Posicionamento psicológico - praça}

Já caminhando para o final das análises cruzadas, este tópico aborda as considerações das empresas acerca do item Praça. Essas principais considerações são apresentadas no Quadro 31, que é complementado por análises gerais.

Todas as três empresas demonstram ter algum nível de preocupação com a distribuição dos seus produtos. Os entrevistados reconhecem a importância do canal de distribuição para o desempenho dos seus produtos. Tanto a Grow como a Pica Pau trabalham com promotores nas principais redes ou lojas que carregam seus produtos. Essa estratégia tenta fazer com que o produto tenha uma presença marcante na gôndola, assim como o apoio do varejista para fazer o produto girar. $\mathrm{O}$ esforço da Pica Pau neste sentido inclui até a troca de produtos que estão encalhados no varejista, para garantir o seu apoio e construir um relacionamento. Ao não utilizar de forma mais significativa as outras ferramentas de comunicação, torna-se compreensível a necessidade de focar as atenções da empresa no ponto de venda. Apesar desse interesse na questão do ponto de venda, as empresas não dedicam seus maiores esforços para as redes supermercadistas, indicando como justificativa a não especialização deste tipo de varejista no consumidor infantil e no setor de brinquedos.

Apesar dos esforços realizados, as três organizações sinalizam para a existência de problemas de distribuição. A Pica Pau trabalha basicamente sua distribuição por meio de representantes, o que limita sua atuação para os locais onde encontra profissionais disponíveis. Destarte, cidades pequenas não são atendidas em razão dessa limitação especifica. Já a Grow indica a existência de problemas de distribuição, principalmente para as áreas mais distantes da sede da empresa, localizada na Grande São Paulo. Essas dificuldades se originam de restrições orçamentárias para promover os produtos nessas regiões. 
Quadro 31 - Comparação teoria e prática - posicionamento psicológico - praça

\begin{tabular}{|c|c|c|c|}
\hline $\begin{array}{l}\text { Revisão da } \\
\text { Literatura }\end{array}$ & Caso & Estratégia Adotada & Análise \\
\hline \multirow{3}{*}{$\begin{array}{l}\text { - Nem todos os } \\
\text { varejistas estão } \\
\text { focados no } \\
\text { consumidor infantil } \\
\text { (MCNEAL, 1992). } \\
\text { - Varejistas mal } \\
\text { preparados para } \\
\text { atender a criança } \\
\text { criam uma } \\
\text { percepção negativa } \\
\text { por parte da criança } \\
\text { em relação ao } \\
\text { varejista em questão } \\
\text { (MCNEAL, 1992). } \\
\text { - As empresas } \\
\text { varejistas deveriam } \\
\text { despender esforços } \\
\text { para tornar o } \\
\text { ambiente mais } \\
\text { amigável para com } \\
\text { a criança } \\
\text { (MCNEAL, 1999). }\end{array}$} & $\begin{array}{l}\text { Pica } \\
\text { Pau }\end{array}$ & $\begin{array}{l}\text { - O foco da empresa é nos varejistas que } \\
\text { trabalham atendendo o segmento popular (p.ex.: } \\
\text { Issan e Armarinhos Fernando), principalmente } \\
\text { por meio de promotores. } \\
\text { - A empresa também está trabalhando a entrada } \\
\text { em varejistas que trabalham segmentos que } \\
\text { procuram produtos mais diferenciados (p.ex.: } \\
\text { Rihappy e Alô Bebê). } \\
\text { - O varejo supermercadista não recebe o mesmo } \\
\text { nível de atenção por não estar focado no } \\
\text { segmento de brinquedos. }\end{array}$ & $\begin{array}{l}\text { - Já com relação à questão da distribuição ou praça, verifica-se uma grande atenção para o } \\
\text { relacionamento com o canal de distribuição, principalmente aqueles varejistas focados no } \\
\text { setor de brinquedos. Esse enfoque coloca o varejo de supermercados numa posição } \\
\text { secundária nas prioridades da empresa. A empresa realiza trocas de produtos para assegurar } \\
\text { o relacionamento com o varejista. Além disso, a empresa também oferece promotoras para } \\
\text { garantir que o produto esteja bem posicionado na gôndola. A empresa valoriza a presença } \\
\text { do produto na gôndola pois considera que o produto se vende sozinho em função do preço. } \\
\text { A entrada em varejistas mais diferenciados não está sendo fácil, como no caso da Alô Bebê. }\end{array}$ \\
\hline & Grow & $\begin{array}{l}\text { - A empresa trabalha tem uma forte atuação } \\
\text { junto ao varejo por meio de promotores de } \\
\text { vendas. } \\
\text { - Em datas importantes são contratados } \\
\text { promotores extra. } \\
\text { - A feira da Abring representa uma } \\
\text { oportunidade de apresentar os produtos da } \\
\text { empresa para o varejo. } \\
\text { - A empresa tem sua distribuição focada nas } \\
\text { regiões mais próximas da empresa. }\end{array}$ & $\begin{array}{l}\text { - Em relação à praça/distribuição percebe-se que existe uma grande preocupação em } \\
\text { trabalhar a apresentação dos produtos da empresa durante a feira da Abrinq. Além disso, a } \\
\text { empresa tem uma estrutura própria de promotores que faz o trabalho de apresentação do } \\
\text { produto no ponto de venda. Em épocas especiais, como no natal e no dia da criança, } \\
\text { promotores temporários são contratados para ter uma participação significativa no ponto de } \\
\text { venda. Um problema enfrentado pela empresa diz respeito à distribuição de seus produtos } \\
\text { para áreas mais afastadas da sede da empresa, localizada na Grande São Paulo. Esse } \\
\text { problema deriva da falta de recursos para investir de forma mais incisiva na promoção e } \\
\text { distribuição dos produtos da empresa nessas áreas mais distantes (norte, nordeste e centro- } \\
\text { oeste). }\end{array}$ \\
\hline & Mitra & $\begin{array}{l}\text { - A distribuição da empresa está focada nas } \\
\text { lojas de brinquedos educativos, principalmente } \\
\text { na Grande São Paulo. } \\
\text { - As lojas de brinquedos educativos são } \\
\text { atendidas por representantes. }\end{array}$ & $\begin{array}{l}\text { - A empresa trabalha um canal de distribuição bastante restrito e pouco abrangente. O } \\
\text { contato com esses varejistas se dá por meio de representantes. Em alguns momentos o } \\
\text { proprietário da empresa participa das ações junto ao varejo, principalmente para transmitir o } \\
\text { conhecimento necessário para vender os jogos que compõem seu portilofio. A empresa não } \\
\text { apresenta nenhuma preocupação com relação a adequação do atendimento fornecido pelos } \\
\text { varejistas para com os seus clientes, como por exemplo o oferecimento de uma área } \\
\text { adequada para a experimentação dos seus produtos. }\end{array}$ \\
\hline
\end{tabular}

Fonte: Elaborado pelo autor com base no referencial teórico e na coleta de dados. 
A Mitra, por sua vez, tenta fazer com que o varejista trabalhe de forma correta seus produtos. Para tanto, são oferecidas oportunidades de treinamento para que os vendedores do varejista tenham um perfeito conhecimento do produto oferecido, da sua história e das regras do jogo. Esse conhecimento se torna um apelo de venda muito importante para a concretização da venda. A empresa também identifica a entrada e saída de empresas focadas no brinquedo educativo como um impedimento para sua estratégia de distribuição. Além disso, algumas lojas varejistas não aceitam o produto da empresa por considerarem ele muito caro ou muito barato, sinalizando mais uma vez para a necessidade de maiores estudos para gerenciar os esforços de marketing da empresa.

Nenhuma das três empresas pesquisadas aborda as questões colocadas pela literatura com relação à adequação do ponto de venda ao consumidor infantil. A preocupação maior das empresas neste momento é conseguir fazer com que seu produto esteja disponível para a compra. Talvez essa preocupação com uma melhor apresentação do produto dentro do ponto de venda ainda seja secundária para essas empresas.

\subsubsection{Posicionamento psicológico - promoção/comunicação}

Finaliza-se esta etapa das análises cruzadas com o item do composto de marketing mais importante para o posicionamento psicológico. As principais considerações dos entrevistados são oferecidas no Quadro 32. A partir do quadro são feitas as principais análises necessárias.

Dentre as três pesquisadas, apenas a Grow conduz esforços mais elaborados de comunicação de seus produtos e marcas. As outras, por sua vez, investem na comunicação de forma muito restrita. A Grow comunica seus produtos tanto em propagandas na televisão (canais abertos e televisão a cabo), ações em shopping centers, site e material promocional no ponto de venda. Essas ações ainda são restritas a algumas linhas de produtos. Para as linhas de produtos que são lançadas com a chancela de um personagem não se faz tão necessário o invesimento em propagandas, pois estes produtos são naturamente preferidos pelas crianças no próprio ponto de venda.

A Grow também valoriza a realização de ações em conjunto com outras empresas, apesar de ter uma atitude muito proativa para que se realize tal estratégia. A empresa está aberta a negociações 
deste tipo, mas na maioria dos casos ela é procurada por empresas interessadas, não realizando ações proativas para colocar em prática este tipo de estratégia.

A Pica Pau restringe-se ao uso de promotores em algumas lojas e a exposição de seus produtos no site da empresa. Os diretores consideram que o preço de seus produtos e o boca-a-boca positivo dos seus produtos já é o bastante para fazer seu produto ser conhecido e requisitado no mercado.

A empresa Mitra é a que tem as maiores restrições com relação à promoção, trabalhando apenas o treinamento de vendedores das lojas que carregam seus produtos e o site como forma de apresentar os produtos. Tanto a Pica Pau como a Mitra reconhecem que maiores esforços de promoção teriam resultados positivos, mas não os realizam, muito em parte em função de restrições orçamentárias, principalmente no caso da Mitra. A Grow também assinala que tem problemas orçamentários para conduzir os seus esforços de marketing de maneira adequada. No caso da Grow, essa situação é critica em razão da eminente entrada da multinacional Hasbro no mercado, que com recursos e apoio de estratégias de marketing mais refinadas poderá trazer sérios problemas para a empresa. 
Quadro 32 - Comparação teoria e prática - posicionamento psicológico - promoção

\begin{tabular}{|c|c|c|c|}
\hline Revisão da Literatura & Caso & Estratégia Adotada & Análise \\
\hline \multirow{3}{*}{$\begin{array}{l}\text { - Crianças podem ser } \\
\text { encontradas em casa, em lojas, } \\
\text { na comunidade, nas escolas e } \\
\text { em carros (ACUFF e } \\
\text { REIHER, 1997). } \\
\text { - O impacto das ferramentas } \\
\text { de comunicação (propaganda } \\
\text { na mídia televisiva, } \\
\text { embalagem, promoções, } \\
\text { revistas e livros, jornal, rádio, } \\
\text { computadores e internet) tem o } \\
\text { seu impacto mediado pela } \\
\text { idade da criança (ACUFF e } \\
\text { REIHER, 1997). } \\
\text { - Uma das decisões mais } \\
\text { importantes na propaganda é } \\
\text { decidir se ela estará } \\
\text { direcionada para a criança, } \\
\text { para os pais ou para ambos } \\
\text { (SIEGEL et al., 2001). } \\
\text { - A empresa deve atentar para } \\
\text { as repercussões éticas das suas } \\
\text { ações direcionadas } \\
\text { diretamente para a criança } \\
\text { (KOUZELEAS, 2005). } \\
\text { - A propaganda deve utilizar } \\
\text { crianças mais velhas do que } \\
\text { aquelas para quem a } \\
\text { propaganda é direcionada, pois } \\
\text { essas crianças desejam se } \\
\text { distanciar dos grupos mais } \\
\text { jovens (ACUFF e REIHER, } \\
\text { 1997). }\end{array}$} & $\begin{array}{l}\text { Pica } \\
\text { Pau }\end{array}$ & $\begin{array}{l}\text { - A comunicação da empresa está focada no canal de } \\
\text { distribuição. } \\
\text { - Não existem esforços de comunicação com o } \\
\text { consumidor, ou com seus pais. } \\
\text { - A empresa disponibiliza um site que apresenta os } \\
\text { produtos da empresa e fornece um email para um } \\
\text { contato maior. } \\
\text { - A empresa fundamenta sua comunicação na } \\
\text { expectativa de que ocorra o boca-aboca positivo de } \\
\text { seus produtos. } \\
\text { - Esporadicamente são inseridas propagandas em } \\
\text { revistas direcionadas ao canal distribuidor. }\end{array}$ & $\begin{array}{l}\text { - A comunicação da empresa está quase que totalmente direcionada para } \\
\text { o canal de distribuição, por meio de inserções em revistas direcionadas } \\
\text { ao canal. Inexistem esforços de comunicação com o consumidor. O único } \\
\text { contato averiguado se dá passivamente por meio do site da empresa e do } \\
\text { email que lá está apresentado. Essa opção da empresa fundamenta-se na } \\
\text { percepção de que o preço e a comunicação boca a boca já são o bastante } \\
\text { para fazer o produto girar. Apesar de reconhecer que um esforço de } \\
\text { comunicação poderia aumentar as vendas da empresa, não são } \\
\text { conduzidos esforços nesse sentido. }\end{array}$ \\
\hline & Grow & $\begin{array}{l}\text { - A empresa utiliza a propaganda televisiva como } \\
\text { ferramenta principal, mas apenas para alguns } \\
\text { produtos. Nessas propagandas utilizam-se atores mais } \\
\text { velhos que o público-alvo. } \\
\text { - A empresa também realiza esporadicamente ações } \\
\text { promocionais em shopping centers. } \\
\text { - São realizadas atividades junto ao varejo, como } \\
\text { participação em tablóides e encartes e trabalhos } \\
\text { promocionais no ponto de venda. } \\
\text { - A empresa disponibiliza um site que serve para } \\
\text { apresentar os produtos da empresa, sem oferecer a } \\
\text { oportunidade da compra on-line ou da comunicação } \\
\text { mais efetiva entre a empresa e os consumidores. } \\
\text { Parceria com outros sites disponibilizam alguns jogos } \\
\text { da empresa para o jogo entre usuários da rede. }\end{array}$ & $\begin{array}{l}\text { - Para a área de comunicação/promoção, a empresa desenvolve uma série } \\
\text { de iniciativas para estar em contato com o consumidor passando o seu } \\
\text { posicionamento. A empresa insere propagandas na televisão aberta e na } \\
\text { televisão paga (cabo). Para essas propagandas a empresa utiliza atores } \\
\text { com idades superiores a idade do público-alvo da propaganda/produto, } \\
\text { visando criar a percepção de que a criança que compra e utiliza } \\
\text { determinado produto pertence a um segmento de crianças com uma idade } \\
\text { superior. Essas propagandas focam diretamente as crianças, não sendo } \\
\text { realizada nenhuma ação direcionada para os pais. Também faz ações } \\
\text { especiais em shopping centers, realiza ações cooperadas para a } \\
\text { apresentação de produtos e disponibiliza o jogo on-line. Em relação ao } \\
\text { ponto de venda, a empresa participa de encartes e tablóides e trabalha o } \\
\text { ponto de venda com a colocação de materiais promocionais. }\end{array}$ \\
\hline & Mitra & $\begin{array}{l}\text { - Praticamente toda a comunicação da empresa reside } \\
\text { no uso de representantes. } \\
\text { - A empresa mantêm no ar um site com algumas } \\
\text { informações sobre os produtos da empresa, mas não } \\
\text { existe a oportunidade da compra on-line nem de um } \\
\text { maior relacionamento com os consumidores. }\end{array}$ & $\begin{array}{l}\text { - A comunicação da empresa é feita por meio dos representantes e dos } \\
\text { próprios proprietários da empresa, que fornecem aos vendedores dos } \\
\text { lojistas o treinamento necessário para compreender os jogos e poder } \\
\text { trabalhar um apelo de venda focado no caráter histórico do jogo. A } \\
\text { empresa também tem um site, que se restringe a apresentar os produtos } \\
\text { da empresa, não oferecendo a oportunidade da compra on-line. As ações } \\
\text { da empresa são escassas em razão de restrições financeiras. }\end{array}$ \\
\hline
\end{tabular}

Fonte: Elaborado pelo autor com base no referencial teórico e na coleta de dados. 


\subsubsection{Posicionamento psicológico - considerações gerais}

De forma geral os esforços de posicionamento psicológico das empresas é restrito e falho. Primeiramente, faltam informações para que esta etapa do posicionamento seja conduzida de forma correta e mais adequada. Mesmo sem essas informações, as empresas poderiam trabalhar de forma mais completa o seu composto de marketing, principalmente a promoção, para levar ao consumidor o seu posicionamento, fato não observado. Apenas a Grow apresenta esforços mais complexos de posicionamento, mas limitados geograficamente em função de restrições orçamentárias.

O tamanho das empresas e os recursos disponíveis para investimento são os principais responsáveis por esta situação. As fábricas ressaltam a importância de trabalhar os recursos escassos para direcioná-los para as áreas mais importante e, dessa forma, os investimentos maiores se faz no ponto de venda.

Apesar dos problemas apresentados, as empresas estão comercializando seus produtos com certo nível de sucesso. Em todos os casos, esse sucesso pode ser derivado de uma característica peculiar de cada empresa que restringe a ação de competidores. A Grow fundamenta suas atividades no licenciamento, que tem em sua definição um caráter de exclusividade. A Pica Pau sinaliza que a grande maioria dos seus produtos não tem concorrente direto dentro do segmento. Já a Mitra trabalha com um formato exclusivo no nicho de brinquedos educativos. Se não fossem esses fatores as empresas se veriam obrigadas a trabalhar de forma mais aprofundada as suas estratégias de marketing. 


\section{CONSIDERAÇÕES FINAIS}

Este trabalho surge de uma análise dos estudos que cercam a área do consumo infantil. Percebeuse que este é um campo que ainda não foi alvo dos estudos necessários para que se possa afirmar que existe um corpo teórico consistente sobre o tema. Partindo desse enfoque, desenvolveu-se uma análise para identificar qual seria o caminho mais adequado para adentrar seus limites epistemológicos. Identificou-se que o estudo dos processos de segmentação e posicionamento realizados por empresas focadas no consumidor infantil poderia trazer importantes considerações sobre as estratégias das empresas perante este público em particular, que claramente merece ser alvo de estudos mais aprofundados em razão da criança passar por uma série de mudanças físicas, sociais e cognitivas durante o seu crescimento.

Diante das considerações acima surgiu o objetivo de pesquisa deste trabalho: Identificar as estratégias de segmentação e posicionamento que são apresentadas na literatura de marketing e verificar se as empresas focadas no mercado infantil seguem as sugestões da literatura. Para atingir esse objetivo algumas etapas foram transpostas.

Primeiramente, foi conduzido um esforço de pesquisa para identificar a literatura relevante sobre o tema, buscando responder a questão de pesquisa inicialmente proposta. Como primeira etapa desse levantamento, buscou-se analisar a literatura de segmentação e posicionamento, visando aprofundar o conhecimento do pesquisador sobre o tema e buscar uma melhor descrição dos conceitos aqui estudados. A primeira vista, a literatura acusa a existência de alguns conflitos sobre o significado dos conceitos de posicionamento e segmentação, por isso foram construídos dois quadros com as definições existentes na literatura de marketing. Esse esforço bibliográfico resultou numa análise histórica da evolução dos conceitos. Como resultados desse processo, foram identificados os principais componentes de cada conceito.

Em um segundo momento da revisão teórica, averiguou-se na literatura que trata o consumidor infantil as recomendações sobre as estratégias de posicionamento e segmentação que visam este 
público. A literatura nacional não apresentou aportes significativos, indicando a existência de uma lacuna na academia brasileira de marketing.

Em função dessa brecha, buscou-se o aporte de trabalhos realizados no exterior para gerar o suporte teórico necessário para a realização deste trabalho. Esse esforço também não foi eficaz para atender aos requisitos propostos inicialmente e, sendo assim, foi necessário buscar algumas fontes oriundas de outras áreas do conhecimento, principalmente de estudos que tratam do desenvolvimento cognitivo e social e do processo de socialização. Estas pesquisas tiveram um papel importante na compreensão das atividades das empresas em relação à adequação de seus produtos para as diferentes faixas etárias que dividem as diferentes capacidades da criança ao longo de seu processo de desenvolvimento.

O esforço para construir um referencial teórico que respondesse aos questionamentos iniciais deste trabalho não foi conclusivo, ou seja, não foi possível identificar na literatura uma resposta para o problema de pesquisa. Essa situação gerou a necessidade da realização de uma pesquisa de campo que buscasse na ação prática das empresas as respostas para a questão colocada.

A pesquisa de campo teve como objetivo identificar as ações de segmentação e posicionamento realizadas por empresas focadas no mercado infantil. $\mathrm{O}$ foco nos conceitos de segmentação e posicionamento é justificado por uma série de autores que consideram que a segmentação é a primeira etapa do processo de elaboração da estratégia de marketing da empresa (LAMBIN, 2001) e faz parte da implementação do conceito de marketing (WIND, 1978; DANNEELS, 1995; HOOLEY e SAUNDERS, 1996), sendo o posicionamento derivado do processo de segmentação (TOLEDO e HEMZO, 1991; DIBB, 1999).

Campomar (1991) sinaliza para a importância da escolha do método de pesquisa deve ser resultante da análise das características do problema de pesquisa. Essa sugestão não é sempre seguida, o que pode ser verificado pela profusão de estudos que utilizam o método quantitativo por meio da análise de equações estruturais. Parece haver na academia uma urgência em trabalhar métodos da moda, que por sua vez aumentam as chances de aprovação em revistas e congressos da área. 
Uma escolha metodológica focada nos métodos quantitativos seria inadequada, pois não é objetivo deste trabalho quantificar de nenhuma forma as estratégias adotadas pelas empresas. É objetivo identificar quais são essas estratégias, sendo assim, conforme Yin (2001) a escolha mais adequada seria pelo método do estudo de caso. Também faz voz a esta escolha as considerações de Mason (1996), que aconselha o uso de métodos qualitativos para ocasiões onde necessita-se da geração flexível de dados, de acordo com o contexto onde a própria empresa está inserida. Este é claramente a situação desta pesquisa, que foca em empresas que atuam junto ao consumidor infantil, tema caracterizado por McNeal (1992; 1999; 2007) como contemporâneo. Perry (1998) indica que a área de marketing pode se beneficiar profundamente de trabalhos que utilizam o método do estudo de caso quando estudam tópicos contemporâneos, fundamentando ainda mais a escolha metodológica deste trabalho.

A escolha do setor onde seriam pesquisadas as empresas derivou de uma análise dos diferentes segmentos que atendem o mercado infantil. Reflexões realizadas pelo pesquisador levaram a escolha do setor de brinquedos por se tratar de um segmento onde as empresas estão realmente focadas no consumidor juvenil. Outros segmentos da economia também têm este consumidor como alvo, mas talvez não de forma tão clara e especifica como o setor de brinquedos. O enfoque no setor de brinquedos é recorrente na literatura de marketing (BRÉE, 1995; ACUFF e REIHER, 1997; MONTIGNEAUX, 2003; SIEGEL et al., 2001; FISCHEL, 2001; LINDSTROM e SEYBOLD, 2003; VECCHIO, 2002) e, por isso, justifica a escolha do setor com base na importância que estes autores lhe dão. Ademais, a escolha de um setor que já foi alvo de estudos facilita e permite o aprofundamento dos achados de pesquisa do trabalho.

Para a coleta de dados, selecionou-se a técnica de entrevista em profundidade, pois é uma das mais utilizadas neste tipo de trabalho (MARSHALL e ROSSMAN, 1995). Destarte, foram contatadas as empresas que fazem parte da principal entidade que reúne as empresas do setor, a Abrinq. A própria entidade não demonstrou grande interesse no trabalho, não retornando os contatos realizados e não disponibilizando maiores informações. A participação da Abrinq no trabalho restringiu-se a disponibilizar um cadastro acessível para qualquer pessoa no site da 
entidade. Ao total, buscou-se o contato com 80 empresas, das quais apenas 3 aceitaram participar da pesquisa.

É lamentável perceber que as empresas do setor de brinquedos e a entidade que as representa não dão a devida importância aos esforços acadêmicos para avançar o conhecimento na área, atividade que certamente trará frutos para as próprias empresas e para a entidade que as representa. Enquanto nos Estados Unidos existem entidades, como o MSI - Marketing Science Institute (2008), que congregam as empresas e o mundo acadêmico, visando o desenvolvimento do conhecimento, aqui no Brasil ainda existe grande desconfiança com relação ao trabalho realizado por cientistas sociais. Além disso, as empresas também não acreditam que despender algum esforço de tempo e acesso para transferir informações para os acadêmicos seja de alguma valia. Isso talvez decorra da falta de proximidade que existe entre a academia e o mundo empresarial.

As três empresas que aceitaram participar da pesquisa de campo foram alvo de entrevistas em profundidade. As entrevistas duraram em média cerca de uma hora, seguindo as recomendações da literatura (MAYKUT e MOREHOUSE, 1996). As entrevistas foram gravadas e transcritas, criando um banco de dados que constitui a base para as análises realizadas. Utilizando-se orientações da literatura conduziu-se uma análise individual de cada caso, objetivando comparar as atividades da empresa com as recomendações da literatura. Posteriormente foi conduzido um esforço cruzado de análise dos casos, também seguindo orientações da literatura (EISENHARDT, 1989).

Os principais resultados apontam para um setor que ainda sofre com falta de recursos para conduzir as ações de marketing necessárias para atingir o seu potencial competitivo. As empresas trabalham de forma bastante amadora, suportando suas decisões na experiência prática dos seus gestores. Campomar e Ikeda (2006, p.7) identificam que de "modo geral os administradores tomam decisões baseados na intuição, prática (ações, atividades) e tradição". Essa situação claramente traz restrições competitivas para as empresas. 
$\mathrm{O}$ achado de pesquisa mais preocupante relaciona-se com a quase inexistência de pesquisas de qualquer tipo com os consumidores. As empresas não fazem pesquisa para segmentar o mercado e fazem apenas alguns testes "caseiros" para verificar as possibilidades de um novo lançamento. Duas das empresas pesquisadas introduzem seus produtos com base em observações do mercado internacional e no feeling dos gestores, o que mais uma vez suporta as considerações de Campomar e Ikeda (2006) sobre o estágio atual do marketing no Brasil.

Os esforços de posicionamento são muito limitados em relação às inúmeras possibilidades existentes. Apenas uma empresa realiza ações mais coordenadas de posicionamento, as outras empresas restringem-se a trabalhar a distribuição dos produtos e realizar algumas escassas ações no ponto de venda.

As empresas justificam essa situação em função de restrições orçamentárias e na estrutura de mercado, que não exige dessas empresas o uso de técnicas mais sofisticadas de marketing para atender a seus consumidores. Essa situação só mudará quando os players se sentirem pressionados pela concorrência.. No entanto, aqueles que perceberem as possibilidades do uso mais completo das ferramentas de marketing terão claras vantagens sobre seus concorrentes no mercado.

Os entrevistados percebem que no mercado nacional apenas uma empresa trabalha de forma mais agressiva, a Mattel. Essa empresa é vista como uma empresa "estranha no ninho", por sua combatividade no ponto de venda. Realizando ações que são consideradas pelos entrevistados como fora do padrão. A entrada da maior multinacional do setor de brinquedos certamente trará um novo patamar de competição para o mercado, mas empresas menores e focadas em outros segmentos, como a Pica Pau e a Mitra, não serão atingidas. O impacto maior será sentido pela Grow, que obrigatoriamente se verá necessitando de maiores aportes das estratégias mais atuais de marketing.

De forma resumida, é possível concluir que a resposta ao problema de pesquisa colocado - Quais são as estratégias de segmentação e posicionamento adotadas por empresas focadas no mercado infantil? - é que as empresas não conduzem esforços estruturados de segmentação, preferindo tomar decisões com base na tradição da empresa ou no feeling. Além disso, os esforços de 
posicionamento são bastante restritos, sendo decididos pela experiência prática dos executivos e pela observação de mercados internacionais.

\subsection{Limitações do trabalho}

Todo trabalho acadêmico deve trazer em algum momento uma reflexão sobre as limitações do seu esforço de pesquisa. Todo e qualquer busca é um processo continuo de decisões, que procura escolher o caminho mais adequado para responder as questões colocadas pelos próprios pesquisadores. Essas decisões têm um claro impacto na abrangência do trabalho, não desmerecendo a diligência, mas sim esclarecendo o escopo dos resultados alcançados.

As conclusões aqui apresentadas refletem apenas as considerações dos entrevistados sobre as questões que lhes foram postas. Por isso, não é possível estender os resultados do trabalho para a totalidade das empresas que compõem o setor de brinquedos. É claro que é possível discutir os resultados, aventando as repercussões que teriam caso também fossem válidos para o setor, mas é necessário estabelecer essa limitação, que restringe o trabalho para as empresas pesquisadas.

Este trabalho optou por realizar um estudo de caso, sendo que a coleta de dados foi baseada na técnica de entrevista em profundidade. Apesar de ser uma escolha justificada pela literatura, é possível que outros métodos de coleta de dados, utilizados de forma triangular, fossem mais adequados, trazendo uma profundidade maior aos resultados aqui apresentados.

Também é limitação deste trabalho a realização de entrevistas únicas com as empresas. A literatura que trata do estudo de caso sugere que sejam feitas múltiplas entrevistas com múltiplos respondentes para trazer uma maior profundidade aos dados coletados. Era objetivo deste trabalho realizar tal esforço, porém não foi possível coordenar este tipo de atividade com as empresas pesquisadas. 
As limitações do estudo derivam para a necessidade de considerações sobre pesquisas futuras que poderiam preencher as lacunas deixadas por este trabalho em particular. Dessa forma, a seguir são apresentadas sugestões.

\subsection{Sugestões de pesquisas futuras}

Apesar das limitações apresentadas, considera-se que o trabalho trouxe importantes informações para os interessados em desenvolver estudos futuros sobre o tema. A partir de uma primeira reflexão, é possível conceber que um estudo de caso que abrangesse mais empresas e utilizasse outros métodos de coleta de dados poderia trazer maiores informações.

Os elementos aqui contidos permitem que se estabeleça algumas hipóteses de pesquisa que verifiquem se a situação encontrada nas empresas pesquisadas se repete no restante do mercado. Será que nenhuma empresa do setor de brinquedos conduz atividades de segmentação? Será que nenhuma empresa trabalha a pesquisa para realizar pré-testes dos seus lançamentos? Esse esforço de pesquisa poderia acontecer por meio de uma coleta de dados com caráter quantitativo. A presente pesquisa permite, assim, a elaboração de um instrumento de coleta de dados quantitativo que possibilitasse uma pesquisa com uma abrangência maior.

Também caberiam esforços de pesquisa para identificar qual a percepção do público-alvo das empresas sobre o posicionamento dos produtos oferecidos. O método de coleta de dados por meio de desenhos seria bastante interessante para conduzir este tipo de pesquisa. Essa consideração segue orientações da literatura focada no consumidor infantil, que vê a coleta de desenhos como um método não intrusivo adequado ao segmento (MCNEAL, 1992; 1999; 2007). Essa sugestão decorre da necessidade das empresas realizarem atividades para avaliar a efetividade dos seus esforços, ou seja, se o posicionamento pretendido está sendo internalizado pelo público-alvo.

Outra pesquisa que poderia trazer importantes aportes para a literatura trataria da observação do processo de escolha do brinquedo no ponto de venda. Seria interessante verificar a participação 
da criança e de seus pais/parentes na escolha dos brinquedos. Esse tipo de pesquisa poderia ser realizado por meio do método de observação e também por meio de entrevistas com o responsável pela compra, seja ele um dos progenitores ou um parente comprando um presente de aniversário. Esse enfoque, baseado na área de comportamento do consumidor, é uma das principais sugestões de pesquisa colocadas pelo MSI (2008, p.3), reafirmando a importância de estudos que busquem compreender o comportamento do consumidor infantil.

\subsection{Implicações gerenciais}

É importante que trabalhos acadêmicos da área da administração permitam comentários sobre a aplicabilidade dos achados. Afinal um objetivo importante dos trabalhos focados na administração, ou mais precisamente no marketing, é trazer aportes para facilitar e otimizar as relações comerciais estabelecidas entre organizações e consumidores.

Este trabalho indica que as empresas ainda não atentaram para todas as possibilidades que o pleno uso das ferramentas e da filosofia de marketing pode trazer para os seus resultados financeiros. Uma companhia que, ao ter acesso a este trabalho, decida por dedicar maiores esforços para a condução de um processo de marketing mais elaborado, poderia conquistar importantes vantagens perante seus concorrentes. Campomar e Ikeda (2006) consideram que essa realidade irá mudar com o aprofundamento de estudos na área de marketing e com o desenvolvimento de programas acadêmicos onde se estuda o marketing de forma adequada. 


\section{REFERÊNCIAS}

AAKER, David A. Marcas - Brand Equity: Gerenciando o Valor da Marca. São Paulo, Elsiever, 10 Ed.,1998, p.1-309.

AAKER, David A.; DAY, George S. Investigación de Mercados. McGraw-Hill, México, 1989, p.1-715.

AAKER, David A.; SHANSBY, J. Gary. Positioning Your Product. Business Horizons. Vol. 25 (3), May-June 1988, p.56-62.

AAKER, David A.; KUMAR, V.; DAY, George S. Pesquisa de Marketing. São Paulo, Ed. Atlas, 2001.

ABRAL, Associação Brasileira de Licenciamento. Disponível em: http://www.abral.org.br/default.asp?tp=1\&pag=conteudo/cont_250208.htm. Acessado em: 05/05/2008.

ABRINQ. Associação Brasileira de Fabricantes de Brinquedos - Área de noticiais. Disponível em http://www.abrinq.com.br/index.cfm?conteudo_ID=26. Acessado em 05/11/2007.

ABRINQ. Associação Brasileira de Fabricantes de Brinquedos. Disponível em http://www.abrinq.com.br/index.cfm?conteudo_ID=27. Acessado em 05/02/2005.

ABRINQ. Associação Brasileira de Fabricantes de Brinquedos. Disponível em http://www.abrinq.com.br/index.cfm?conteudo_ID=27. Acessado em 19/05/2008

ACHENBAUN, Alvin A. Who Says You Need Research to Position a Brand? Journal of Advertising. Vol. 3 (3), 1974, p.21-24 e 41.

ACHENREINER, Gwen Bachmann; JOHN, Deborah Roedder. The Meaning of Brand Names to Children: A Developmental Investigation. Journal of Consumer Psychology. Vol. 13(3), 2003, p. 205-219.

ACUFF, Dan S.; REIHER, Robert H. What Kids Buy and Why - The Psychology of Marketing to Kids. USA, Free Press, 1997.

AHUJA, Roshan; CAPELLA, Louis M.; TAYLOR, Ronald D. Child Influences, Attitudinal and Behavioral Comparison Between Single Parent and Dual Parent Household In Grocery Shopping Decisions. Journal of Marketing Theory and Practice, Vol. 6 (1), Winter, 1998. 
ALPERT, Lewis.; GATTY, Ronald. Product Positioning by Behavioral Life-Styles. Journal of Marketing. Vol. 33 (2), Apr. 1969, p.65-69.

AMA - American Marketing Association. Press release - The American Marketing Association Releases New Definition for Marketing. Disponível em: http://www.marketingpower.com/. Acessado em: 07 de junho de 2008b.

AMA - American Marketing Association. Dictionary of Marketing Terms. Disponível em: http://www.marketingpower.com/. Acessado em: 3 de março de 2008a.

ANDERSON, Eugene W.; SHUGAN, Steven M. Repositioning for Changing Preferences: The Case of Beef Versus Poultry. Journal of Consumer Research. Vol. 18 (2), Sep 1991, p.219232.

ANDREASEN, Alan R. Geographic Mobility and Market Segmentation. Journal of Marketing Research. Vol. III, November 1966, p.341-348.

ANSARI, Asim; ECONOMIDES, Nicholas, GHOSH; Avijit. Competitive Positioning in Markets With Nonuniform Preferences. Marketing Science. Vol. 13(3), Summer 1994, p.248-273.

ASSAEL, Henry. Segmenting Markets By Group Purchasing Behavior: An Application of the AID Technique. Journal of Marketing Research. Vol. VII, May 1970, p.153-158.

ASSAEL, Henry; ROSCOE, A. Marvin. Approaches to Market Segmentation Analysis. Journal of Marketing. October 1976, p.67-76.

ATAUJE, Ruth Noemi Aparício. O Processo de Posicionamento de Marketing: Estudo de Caso Junto a uma Empresa de Automação Industrial. Dissertação de Mestrado apresentada na FEA-USP, 2000, p.1-137.

AUTY, Susan; LEWIS, Charlie. Exploring Children's Choice: The Reminder Effect of Product Placement. Psychology \& Marketing. Vol. 21 (9), Sep. 2004, p. 697-713.

AZZARONE, Stephanie. Tweens, Teens and Technology: What's important now. Advertising \& Marketing to Children, Out.-Dez. 2003, p.57-61.

BABBIE, Earl. The Practice of Social Research $\mathbf{9}^{\text {th }}$ edition. Wadsworth, Australia, 2000, p.1498. 
BANNON, Lisa. Cresce participação de crianças na economia. O Estado de S. Paulo, São Paulo, 19 out. 1998.

BARNETT, Norman L. Beyond Market Segmentation. Harvard Business Review. JanuaryFebruary 1969, p. 152-166.

BASS, Frank M.; TIGERT, Douglas J.; LONSDALE, Ronald T. Market Segmentation: Group versus Individual Behavior. Journal of Marketing Research. Vol. V, August 1968, p.264-270.

BHATTACHARYA, C. B. e SEN, S. Consumer--Company Identification: A Framework for Understanding Consumers' Relationships with Companies. Journal of Marketing. v.67, 2003, p.76-88.

BEANE, T. P.; ENNIS, D. M. Market Segmentation: A Review. European Journal of Marketing. Vol. 21(5), 1987, p.20-42.

BEDBURY, SCOTT; FENICHELL, Stephen. O Novo Mundo das Marcas: 8 Princípios para a sua Marca Conquistar a Liderança. Ed. Campus, Rio de Janeiro, 2002, p.1-260.

BELK, Russell W. Possessions and Extended Self. Journal of Consumer Research. Vol. 15, September 1988, p. 139-168.

BEVERLAND, Michael B. Repositioning New Zealand Venison: From Commodity to Brand. Australasian Marketing Journal. Vol. 13 (1), 2005, p.62-67.

BLACKWELL, Roger D.; MINIARD, Paul W.; ENGEL, James F. Comportamento do Consumidor. Pioneira Thomson Learning, São Paulo, 9a Edição (trad.), 2005, p.1-606.

BLANKSON, Charles; KALAFATIS, Stavros P. Issues and Challenges in the Positioning of Service Brands: A Review. Journal of Product \& Brand Management. Vol. 8(2), 1999, p.106118.

BOWMAN, Burton F.; MCCORMICK, Frederick E. Market Segmentation and Marketing Mixes. Journal of Marketing. January, 1961, p.25-29.

BRADLEY, Frank. Strategic Marketing - In the Customer Driven Organization. John Wiley \& Sons Ltd, Chichester, 2003, p. 1-287.

BRANDT, Steven C. Dissecting the Segmentation Syndrome. Journal of Marketing. Vol. 30, October 1966, p.22-27. 
BRÉE, Joel. Los Niños, el Consumo y el Marketing. Barcelona, Ed. Paidós, 1995, p.1-318.

BRIDGES, Eileen; Briesch, Richard A. The 'nag factor' and children's product categories. International Journal of Advertising. Vol. 25(2), 2006, p.157-187.

BROMLEY, D. B. The Case Study Method in Psychology and Related Disciplines. John Wiley \& Sons, Chichester, 1986, p,1-351.

CABLE - National Cable \& Telecomunications Associations. Disponível em: http://www.ncta.com/Statistic/Statistic/Statistics.aspx. Acessado em: 24/05/2008.

CALANTONE, Roger J; SAWYER, Alan G. The Stability of Benefit Segments. Journal of Marketing Research. Vol. XV, August 1978, p.395-404.

CAMPOMAR, Marcos C.; GIL, Camila. Analisando VALS como Instrumento de Segmentação. Anais do IX SEMEAD, 2006. Disponível em: http://www.ead.fea.usp.br/semead/9semead/resultado_semead/trabalhosPDF/178.pdf. Acessado em: 11/03/2008.

CAMPOMAR, Marcos Cortez. Do Uso de "Estudo de Caso" em Pesquisas para Dissertações e Teses em Administração. Revista de Administração, São Paulo, Vol. 26(3), julho/setembro 1991, p.95-97.

CAMPOMAR, Marcos Cortez; IKEDA, Ana Akemi. Falácias em Marketing. Anais do II EMA - Encontro de Marketing da Anpad. Rio de Janeiro, 2006, p.1-8.

CARLSON, Les; GROSSBART, Sanford. Parental Style and Consumer Socialization of Children. The Journal of Consumer Research. Vol. 15 (1), Jun., 1988, p. 77-94.

CARMICHAEL, L. Manual de psicologia da criança. Edusp, São Paulo, 1975.

CEPEDA, Gabriel; MARTIN, David. A Review of Case Studies Publishing in Management Decision 2003-2004: Guides and Criteria for Achieving Quality in Qualitative Research. Management Decision. Vol. 43(5/6), 2005, p.851-876.

CHAN, Kara. Hong Kong Children's Understanding of Television Advertising. Journal of Marketing Communications. Vol. 6, 2000, p. 37-52.

CHAPLIN, Lan N.; JOHN, Deborah R. The Development of Self-Brand Connections in Children and Adolescents. Journal of Consumer Research. Vol. 32, June 2005, p. 119-129. 
CHERNATONY, Leslie de; DANIELS, Kevin; JOHNSON, Gerry. Competitive Positioning Strategies Mirroring Sellers' and Buyers' Perceptions? Journal of Strategic Management. Vol. 1, 1993, p.229-248.

CHURCHILl, Gilbert A.; PETER, J. Paul. Marketing- Criando Valor para os Clientes. Ed. Saraiva, São Paulo, 2a Edição, 2005, p.1-626.

CLANCY, Kevin. Abaixo a Intuição. HSM Management. Vol. 33, Julho-Agosto, 2002.

CLAYCAMP, Henry J.; MASSY, William F. A Theory of Market Segmentation. Journal of Marketing Research. Vol. V, November 1968, p.388-394.

CONAR. Código de Ética do Conar - Conselho Nacional de Auto-regulamentação Publicitária. Disponível em: http://www.conar.org.br/html/novas_normas/index.htm. Acessado em: 17/05/2007.

CROMPTON, John L. Repositioning Leisure Services. Managing Leisure. Vol. 5, 2000, p. 6575.

CROOKS, Heather. A New World of Kid's Magazines. US News \& World Report. 20 August 1990, p. 66-67.

DANNEELS, Erwin. Market Segmentation: Normative Model Versus Business Reality: An Exploratory Study of Apparel Retailing in Belgium. European Journal of Marketing. Vol. 30(6), 1995, p.36-51.

DAVIDOFF, Linda L. Introdução à Psicologia. Pearson-Makron Books, São Paulo, 2001, p.1798.

DENZIN, Norman K.; LINCOLN, Yvonna S. Handbook of Qualitative Research. Sage Publications, Thousand Oaks, 1994, p.1-643.

DIBB, Sally. Criteria Guiding Segmentation Implementation: Reviewing the Evidence. Journal of Strategic Marketing. Vol. 7, 1999, p. 107-129.

DIBB, Sally. Market Segmentation Implementation Barriers and How to Overcome Them. The Marketing Review. Vol. 5, 2005, p.13-30.

DIMINGO, Edward. The Fine Art of Positioning. The Journal of Business Strategy. March/April 1988, p.34-38. 
DONATON Scott. SI for Kids Copycats. Advertising Age. 29 January, p.3.

DONOHUE, Thomas R.; HENKE, Lucy L.; DONOHUE, William A. Do Kids Know What TV Commercials Intend? Journal of Advertising Research. Vol. 20 (5), October 2005, p. p. 51-57.

DOTSON, MICHAEL J.; AND HYATT, EVA M. A comparison of parents' and children's knowledge of brands and advertising slogans in the United States: implications for consumer socialization. Journal of Marketing Communications. Vol. 6, 2000, p.219-230.

DOYLE, Peter; SAUNDERS, John. Market Segmentation and Positioning in Specialized Industrial Markets. Journal of Marketing. Vol. 49(2), Spring 1985, p.24-32.

DUNCAN, Greg J.; BOISJOLY, Johanne; HARRIS, Kathleen M. Sibling, Peer, Neighbor and Schoolmate Correlations as Indicators of the Importance of Context for Adolescent Behavior. Demography. Vol. 38(3), Aug. 2001, p.437-447.

DYER, W. Gibb Jr.; WILKINS, Alan L. Better Stories, Not Better Constructs, to Generate Better Theory: A Rejoinder to Eisenhardt. The Academy of Management Review. Vol. 16(3), Jul 1991, p.613-619.

EISENHARDT, Kathleen M. Better Histories and Better Constructs: The Case for Rigor and Comparative Logic. The Academy of Management Review. Vol. 16(3), Jul 1991, p.620-627.

EISENHARDT, Kathleen M. Building Theories from Case Study Research. Academy of Management Review. Vol. 14 (4), 1989, 532-550.

EKSTROM, Karin N.; TANSUHAJ, Patriya S.; FOXMANN, Ellen R. Children's Influence in Family Decisions and Consumer Socialization - A Reciprocal View. Advances in Consumer Research, Vol. 14, 1987, p.283-287.

ERICKSON Julie L. Food Makers Jump on Microwave Kids Meals. Advertising Age. 7 November 1988, p.2.

ERICKSON_Julie L. Link Leaves Marjani Coke Effervescent. Advertising Age. 1 June 1987, p.2.

ESCALAS, Jennifer Edson; BETTMAN, james r. Self-Construal, Reference Groups, and Brand Meaning. Journal of Consumer Research. Vol. 32, December 2005, p.378-389.

FEAGIN, Joe R.; ORUM, Anthony, M.; SJOBERG, Gideon. A Case for The Case Study. The University of North Carolina Press, USA, 1991, p.1-290. 
FERNANDES, Fátima. Crianças resistem à retração do consumo. Folha de São Paulo, São Paulo, 8 set. 1997. Caderno dinheiro, p. 2-6.

FERRELL, O.C.; HARTLINE, Michael D. Estratégia de Marketing. Ed. Thomson, São Paulo, 2005, p.1-681.

FIRAT, A., Fuat; SHULTZ, Clifford J. From Segmentation to Fragmentation - Markets and Marketing Strategy in a Postmodern Era. European Journal of Marketing. Vol. 31(3/4), 1997, p.183-207.

FISCHER Christy. Tyson's Looney About Kids. Advertising Age. 18 December 1989, p.3.

FISHEL, Catharine. Designing for Children - Marketing Design That Speak to Kids. Rockport Publishers, Massachusetts, USA, 2001, p.1-160..

FITZGERALD, Kate; LIESSE, Julie. Jetsons Fly Into Hot Licensing Year. Advertising Age. 16 july 1990, p. 43.

FOLHA - Jornal Folha de São Paulo. Debatinho - Como surgiu o dia das crianças. Disponível em http://www2.uol.com.br/debate/1175/cidade/cidade30a.htm. Acessado em 11 de novembro de 2007.

FORD, Jeffrey D.; ELLIS, Elwood A. A Reexamination of Group Influence on Member Brand Preference. Journal of Marketing Research. Vol. 17, February 1980, p. 125-132.

FREEMAN, Laurie. Colgate Makes Play for Kids Market. Advertising Age.12 September 1988, p.24.

FREEMAN, Laurie. J and J Polishes Up New Push at Kids. Advertising Age. 2 January 1989, p.2.

FREEMAN, Laurie. McKids Grow Up. Advertising Age. 1 June 1987, p.82.

FURRIER, Marcio Tadeu; SERRALVO, Francisco Antonio. Processo de Reposicionamento de Marcas: Uma Análise Comparativa de Experiências Brasileiras Vencedoras do Prêmio Top de Marketing no Período de 1999 a 2003. Anais do II EMA - Anpad, Rio de Janeiro, 2006 p.1-17.

GARFIELD, Bob. When Selling to Kids the Loonier the Better. Advertising Age. 5 February 1990, p.50. 
GLESNE, Corrine. Becoming Qualitative Researchers: An Introduction. Longman, USA, $2^{\text {nd }}$ Edition, 1998, p.1-224.

GOUVÊA, Maria Aparecida. Uma Contribuição para o Desenvolvimento de Estratégias de Posicionamento no Contexto do Marketing Bancário. Tese de Doutorado apresentada na FEAUSP, 1991.

GRANATO, A. Baixinhos em crise. Revista Veja. São Paulo, 19 de agosto de 1998.

GREEN, Paul E. A New Approach to Market Segmentation. Business Horizons. February 1977, p.61-73.

GROW, Jogos e Brinquedos Ltda. Disponível em www.grow.com.br. Acessado em 23/05/2008.

HARTMANN, Patrick; IBÁNEZ, Vanessa Apoalaza; SAINZ, F. Javier Forcada. Green Branding Effects on Attitude: Functional versus Emotional Positioning Strategies. Marketing Intelligence \& Planning. 23 (1), 2005, p.9-29.

HASSAN, Salah S.; CRAFT, Stephen H. Linking Global Market Segmentation Decisions With Strategic Positioning Options. The Journal of Consumer Marketing. Vol. 22 (2/3), 2005, p.8189.

HAWKINS, Del I.; CONEY, Kenneth A. Peer Group Influences on Children's Product Preferences. Journal of The Academy of Marketing Science. Vol. 2(2), Spring 1974, p.322331.

HEMZO, Miguel A. Strategic Positioning:Making Sure the Whole Company Tells the Same Story. BALAS Conference Proceedings, 1998, p.1-10.

HEMZO, Miguel Ângelo. O Posicionamento Estratégico de Marketing em Grandes Empresas Alimentícias: Um Estudo Exploratório. Dissertação de Mestrado apresentada na FEA-USP, 1992, p.1-149.

HENDOM, Donald W.; WILLIAMS, Emelda L. Winning the Battle for Your Customer. The Journal of Consumer Marketing. Vol. 2(4), Fall 1985, p.65-75.

HOOLEY, Graham J.; SAUNDERS, John A.; PIERCY, Nigel F. Estratégia de Marketing e Posicionamento Competitivo. Prentice-Hall, São Paulo, 2001, p.1-423.

HOOLEY, Graham J.; SAUNDERS, John. Posicionamento Competitivo: Como Estabelecer e Manter uma Estratégia de Marketing no Mercado. São Paulo, Makron Books, 1996, p.1-367. 
HOUAISS, Dicionário da Língua Portuguesa. Disponível: <www.uol.com.br/educação>. Acesso: 11/07/2007.

HOUSTON, Franklin S.; HANIESKI, John F. Pooled Marketing and Positioning. Journal of Advertising. Vol. 5(1), 1976, p38-39 e 44.

IBGE - Instituto Brasileiro de Geografia e Estatística. Censo de 2000, disponível em www.ibge.gov.br, acessado em 05/02/2006.

Inmetro - Instituto Nacional de Metrologia, Normalização e Qualidade Industrial. Disponível em: http://www.inmetro.gov.br. Acessado em: 21/05/2008.

JOHNSON, Richard M. Market Segmentation: A Strategic Management Tool. Journal of Marketing Research. Vol. VIII, February 1971, p.13-28.

KAIL, Robert V. A Criança. Prentice-Hall, São Paulo, 2004, p.1-545.

KELLER, Kevin L.; AAKER, David A. The Effects of Sequential Introduction of Brand Extensions. Journal of Marketing Research. Vol. 29, February 1992, p. 35-50.

KELLER, Kevin L.; MACHADO, Marcos. Gestão Estratégica de Marcas. Prentice Hall, São Paulo, 2006, p.1-289.

KERIN, Roger A.; HARTLEY, Steven W.; BERKOWITZ, Eric N.; RUDELIUS, William. Marketing. McGraw-Hill, São Paulo, 8a Edição, 2008, p.1-720.

KHATIBI, Ali; HAQUE, Ahasanul; ISMAIL, Hishamudin. Gaining a Competitive Advantage from Advertising: Study on Children's Understanding of TV Advertising. The Journal of American Academy of Business, March 2004, p. 302-308.

KOTLER, Philip.; ARMSTRONG, Gary. Princípios de Marketing. Prentice Hall, São Paulo, $9^{\text {a }}$ Edição, 2005, p.1-593.

KOTLER, Philip; KELLER, Kevin Lane. Administração de Marketing. Person - Prentice Hall, São Paulo, 12a edição, 2006, p.1-750.

KOUZELEAS, Nicky. Direct Marketing - How Far Can You Go? Database Marketing \& Customer Strategy Management. Vol. 12 (3), 2005, p.257-265. 
LAMBIN, Jean-Jacques. Marketing Estratégico. McGrawHill, Portugal, 4a Edição, 2000, p.1756.

LAUTMAN, Martin R. The ABCs of Positioning. Marketing Research. Vol. 5(1), Winter 1993, p.12-18.

LAWLOR, Margaret-Anne; PROTHERO, Andrea. Children's Understanding of Television Advertising Intent. Journal of Marketing Management. Vol. 19, p. 411-431.

LAWRENCE, Jennifer. Seven-Up to Lure Kids. Advertising Age. 5 October 1987, p.3.

LAWRENCE, Jennifer; FITZGERALD, Kate. Nintendo Hits the Spot With Seven-Up. Advertising Age. 25 june 1990,p.59.

LEVY, Sidney. Symbols for Sale. Harvard Business Review. Vol. 37(4), Jul/Aug. 1959, p. 117124.

LIESSE, Julie. Kellogg’s Puts \$30m on Kids. Advertising Age. 9 April 1990, p. 1.

LINDSTROM, Martin. Tweenspeak: The New Branding Language. Advertising \& Marketing to Children, Abr.-Jun., 2003, p.35-42.

LINDSTROM, Martin; SEYBOLD, Patricia B. BrandChild: remarkable insights into the minds of today's global kids and their relationships with brands. Kogan Page, USA, 2003.

LINN, Susan. Consuming Kids: Protecting Our Children from the Onslaught of Marketing \& Advertising. Anchor Publishing, 2005, p.1-304.

LINN, Susan. Crianças do Consumo - A Infância Roubada. Instituto Alana. São Paulo, 2005, p.1-322.

LÓPEZ, Félix. Desenvolvimento Social e Personalidade in COLL, César; PALÁCIOS; MARCHESI, Álvaro. Desenvolvimento Psicológico e Educação - Psicologia Evolutiva. Artmed Editora, Porto Alegre, Vol. 1, 1995, p. 1-356.

LUEG, Jason E.; FINNEY, R. Zachary. Interpersonal Communication in the Consumer Socialization Process: Scale Development and Validation. Journal of Marketing Theory and Practice. Vol. 15(1), 2007, p. 25-39. 
LUQUE, Alfonso; PALACIOS, Jesús. Inteligência Sensório-Motora in COLL, César; PALÁCIOS; MARCHESI, Álvaro. Desenvolvimento Psicológico e Educação - Psicologia Evolutiva. Artmed Editora, Porto Alegre, Vol. 1, 1995, p. 1-356.

MAANEN, John Van. Qualitative Methodology. Sage Publications, Thousand Oaks, 1989, p.1272.

MACKLIN, C. M. Do Young Children Understand the Selling Intent of Commercials? The Journal of Consumers Affairs. Vol. 19 (2), 1985.

MAGGARD, J. P. Positioning Revisited. Journal of Marketing. Vol. 40 (1), 1976, p. 63-66.

MALHOTRA, Naresh K. Pesquisa de Marketing. Porto Alegre, Ed. Bookman, 2001.

MSI. Research Priorities: 2008 - 2010 Guide to MSI Research Programs and Procedures. Disponível em: http://www.msi.org/pdf/MSI_RP08-10.pdf. Acessado em: 7 de junho de 2008.

MARSDEN, Paul. Brand Positioning: Meme's The World. Marketing Intelligence \& Planning. $20(4 / 5), 2002$, p.307-312.

MARSHALL, Catherine; ROSSMAN, Gretchen B. Designing Qualitative Research, 2 ${ }^{\text {nd }}$ Edition. Sage Publications, Thousand Oaks, 1995, p.1-178.

MARTÍ, Eduardo. Inteligência Pré-Operatória in COLL, César; PALÁCIOS; MARTIN, Mary C. Children's understanding of the intent of advertising: A meta-analysis. Journal of Public Policy \& Marketing. Vol. 16(2), Fall 1997, p. 205-216.

MASON, Jennifer. Qualitative Researching. Sage Publications, Thousand Oaks, CA. 1996, p.1180.

MAYKUT, Pamela; MOREHOUSE, Richard. Beginning Qualitative Research - A Philosophical and Practical Guide. The Falmer Press, London, 1996, p.1-194.

MCDONALD, Malcom; DUNBAR, Ian. Market Segmentation - How To Do It, How To Profit From It.. Palgrave, New York, $2^{\text {nd }}$ Edition, 1998, p.1-376.

MCNEAL, James U. Kids as Customers - A Handbook of Marketing to Children. Lexinton Books, New York, 1992. 
MCNEAL, James U. On Becoming a Consumer - Development of Consumer Behavior Patterns in Childhood. Elsevier, Massachusetts, 2007, p.1-408.

MCNEAL, James U. The Child Consumer: A New Market. Journal of Retailing, Vol. 45 (2), Summer 1969, p.15-22.

MCNEAL, James U. The Kids Market - Myths and Realities, Paramount Books, NY, 1999, $272 p$.

MCNEAL, James U.; JI, Mindy, F. Children's Influence on Chinese families' Newfound Leisure Time and its Marketing Implications. Asia Pacific Journal of Marketing and Logistics. Vol. 8 (3), 1996, p.32-57.

MCNEAL, James U.; JI, Mindy, F. Children's Visual Memory of Packaging. The Journal of Consumer Marketing, Vol. 20 (4/5), 2003, p. 400-427.

MITRA - Officina de Criação. Disponível em: http://www.mitracriacao.com.br/. Acessado em 25/05/2008.

MONTE, Edmar Ferreira. Posicionamento no Setor Varejista - O Caso da Rede de Farmácias Pague Menos. Dissertação de Mestrado apresentada na FEA-USP, 1998.

MONTIGNEAUX, Nicolas. Público Alvo: Crianças. Negócio Editora, 2003.

MOORE, Elisabeth. S. Children and the Changing World of Advertising. Journal of Business Ethics. Vol. 52, 2004, p. 161-167, 2004.

MOORE-SHAY, Elizabeth S.; LUTZ, Richard J. Intergenerational Influences in the Formation of Consumer Attitudes and Beliefs About the Marketplace: Mothers and Daughters. Advances in Consumer Research. Vol. 15, 1988, p. 461-467.

MORENO, Maria C.; CUBERO, Rosario. Relações Sociais nos Anos Pré-Escolares: Família, Escola, Colegas in COLL, César; PALÁCIOS; MARCHESI, Álvaro. Desenvolvimento Psicológico e Educação - Psicologia Evolutiva. Artmed Editora, Porto Alegre, Vol. 1, 1995, p. 1-356.

MOSCHIS, George P. Patterns of Consumer Learning. Academy of Marketing Science. Vol. 9 (1/2), 1981, p. 110-126.

MOSCHIS, George P. The Role of Family Communication in Consumer Socialization of Children and Adolescents. The Journal of Consumer Research. Vol 11(4), 1985, p. 898-914. 
MOSCHIS, George P.; CHURCHILL, Gilbert A. Consumer Socialization: A Theoretical and Empirical Analysis. Journal of Marketing Research. Vol. 15 (4), Nov., 1978, p. 599-609.

MOSCHIS, George P.; MOORE, Roy L. An Analysis of the Acquisition of Some Consumer Competencies Among Adolescents. The Journal of Consumer Affairs, Vol. 12 (2), Inverno, 1978, p. 277-291.

MOSCHIS, George P.; MOORE, Roy L. The Role of Family Communications in Consumer Learning. Journal of Communications. Vol. 31(4), Autumm 1981, p.42-52.

MOSCHIS, George P.; MOORE, Roy L.; SMITH, Ruth B. The Impact of Family Communication on Adolescent Consumer Socialization. Advances in Consumer Research. Vol. 11, 1984, p.314-319.

MOSES, Louis J.; BALDWIN, Dare A. What Can the Study of Cognitive Development Reveal About Children's Ability to Appreciate and Cope with Advertising? Journal of Public Policy \& Marketing. Vol. 24 (2), Fall 2005, p. 186-201

MOWEN, John C.; MINOR, Michael S. Comportamento do Consumidor. São Paulo, Pearson Prentice Hall, 2003, p.1-403.

NAGLE, Thomas T.; HOLDEN, Reed K. Estratégia e Tática de Preços - Um Guia para Decisões Lucrativas. São Paulo, Ed. Pearson Prentice Hall, 2005, p.1-383.

NEELEY, Sabrina. Influences on Consumer Socialisation. Young Consumers. Quarter 1, 2005, p. 63-69.

NETTO, Alexandre Annenberg. Brasil: rumo à convergência tecnológica. In: CGI.br (Comitê Gestor da Internet no Brasil). Pesquisa sobre o uso das tecnologias da informação e da comunicação 2006. São Paulo, 2007, pp. 43-46.

NICHOLS, Judith E. Repositioning Fundraising in the 21 st Century. International Journal of Nonprofit and Voluntary Sector Marketing. Vol. 9 (2), 2004, p.163-170.

OATES, Caroline; BLADES, Mark; GUNTER, Barrie; DON, Jacquie. Children's understanding of television advertising: a qualitative approach. Journal of Marketing Communications. Vol. 9, 2003, p. 59-71.

OLIVEIRA, Bráulio. Proposição de Um Modelo de Marketing para o Reposicionamento de Serviços. Tese de Doutorado apresentada na FEA-USP, 2005. 
OLIVEIRA, Bráulio; CAMPOMAR, Marcos Cortez. O Processo de Posicionamento Competitivo em Marketing. Anais do II EMA - Anpad, Rio de Janeiro, 2006 p.1-13.

PAREKH, Rupal. Avis: It's OK to cheat on your car. Advertising Age. Vol. 79 (6), Feb 11, 2008, p.4-6.

PATTON, Michael Q. Qualitative Research \& Evaluation Methods. Sage Publications. Thousand Oaks, CA, $3^{\text {rd }}$ Edition, 2002.

PERRY, Chad. Processes of a Case Study Methodology for Postgraduate Research in Marketing. European Journal of Marketing. Vol. 32(9/10), 1998, p. 785-802.

PIAGET, Jean. Linguagem e o pensamento da criança. Fundo da Cultura, Rio de Janeiro, 1959.

PIAGET, Jean. Linguagem e o pensamento da criança. Fundo da Cultura, Rio de Janeiro, 1959.

PICA PAU, Brinquedos. Disponível em: http://www.brinquedospicapau.com.br. Acessado em: 21/05/2008.

PIRES, Cláudia. Crianças estão mais exigentes para comprar, diz pesquisa. Folha de São Paulo, São Paulo, 4 dez. 1995. Caderno dinheiro, p. 2-5.

PORTER, Michael E. Estratégia competitiva: técnicas para análise de indústrias e da concorrência. São Paulo, Ed. Campus, $17^{\mathrm{a}}$ ed, 1986, p.1-362.

REECE, Bonnie B.; KINNEAR, Thomas C. Indices of Consumer Socialization for Retailing Research. Journal of Retailing. Vol. 62 (3), Fall 1986, p. 267-280.

RICHERS, Raimar. Marketing - Uma Visão Brasileira. RCA Editora, São Paulo, $3^{\text {a }}$ Edição, 2000, p.1-430.

RICHERS, Raimar. Segmentação de Mercado: Uma Visão de Conjunto. 1991a in RICHERS, Raimar; LIMA, Cecília Pimenta. Segmentação: Opções Estratégicas para o Mercado Brasileiro. Ed. Nobel, São Paulo, 1991, p. 1-300.

RIDEOUT, Victoria J. Parents, Children \& Media - A Kaiser Family Foundation Survey. June 2007, p. 1-42. 
RIES, Al; TROUT, Jack. The Positioning Era Cometh. Advertising Age. 1972, Disponível em http://www.ries.com/articles-positioningera.php. Acessado em: 10/03/2008.

ROBERTS, Donald F. FOEHR, Ulla G. RIDEOUT, Victoria J. BRODIE, Mollyyann. Kids \& Media@ The New Millenium - A Kaiser Family Foundation Report. November 1999, p.189.

ROBERTS, Donald F. Parents, Childen and Media - A Kaiser Family Foundation Study. June 2007, p. 1-42.

ROBERTS, Donald F.; FOEHR, Ulla G.; RIDEOUT, Victoria J. Generation M: Media in the Lives of 8-18 Years-Old - A Kaiser Family Foundation Study. March, 2005, p. 1-145.

ROEDDER, Deborah L. Age Differences in Children's Responses to Television Advertising: An Information-Processing Approach. Journal of Consumer Research, Vol. 8, 1981.

ROEDDER, Deborah L.; STERNTHAL, Brian; CALDER, Bobby. Attitude Behavior consistency in Children's Responses to Television Advertising. Journal of Marketing Research. Vol. 20, November 1983, p.337-349.

ROEDDER-JOHN, D. Consumer Socialization of Children: A retrospective Look at Twenty-Five Years of Research. Journal of Consumer Research, Vol 26 (3), Dez., 1999, p. 183-213.

ROY, Donald P.; GRAEFF, Timothy R.; HARMON, Susan K. Repositioning a University Through NCAA Division I-A Football Membership. Journal of Sport Management. Vol. 22, 2008, p.11-29.

RUMMEL, Amy; HOWARD, John; SWINTON, Jennifer M.; SEYMOUR, D. Bradley. You Can't Have That! A Study of Reactance Effects \& Children's Consumer Behavior. Journal of Marketing Theory and Practice, Vol. 8(1), 2000, p.38-44.

SCHIFFMAN, Leon G.; KANUK, Leslie Lazar. Comportamento do Consumidor. LTC Editora, São Paulo, 6 Edição, 2000. p.1-475.

SCHOR, Juliet B. Born to Buy: The Commercialized Child and the New Consumer Culture. Scribner, New York, 2004, p. 1-275.

SHOSTACK, G. Lynn. Service Positioning Through Structural Change. Journal of Marketing. Vol. 51(1), 1987, p.34-43. 
SIEGEL, David L.; COFFEY, Timothy J.; LIVINGSTON, Gregory. The Great Tween Buying Machine - Capturing Your Share of the Multibillion Dollar Tween Market. Dearborn Trade Publishing, 2004

SILK, Alvin J. O que é Marketing. Porto Alegre, Ed. Bookam, 2008, p.1-200.

SILVERMAN, David. Interpreting Qualitative Data - Methods for Analyzing Talk, Text and Interaction. Sage Publications, Thousand Oaks, 1995, p. 1-224. Glesne

SMITH, Ruth B.; MOSCHIS, George B. Consumer Socialization of the Elderly. Advances in Consumer Research, Vol. 11 (1), 1984, p. 548-552.

SMITH, Wendell R. Product Differentiation and Market Segmentation as Alternative Marketing Strategies. Journal of Marketing, ACERTAR VOLUME, July 1956.

SRIVASTAVA, R.K.; Bridge Positioning: Is It a Step Ahead of all Other Positioning Techniques? A Conceptual Paper. Academy of Marketing Studies. Vol. 10(1), 2006, p.67-75.

STAFFORD, James E. Effects of Group Influences on Consumer Brand Preferences. Journal of Marketing Research. Vol. 3(1), Feb 1966, p. 68-75.

STAKE, Robert E. Case Studies.1994, p.236-247 in DENZIN, Norman K.; LINCOLN, Yvonna S. Handbook of Qualitative Research. Sage Publications, Thousand Oaks, 1994, p.1-643.

STAMPFL, Ronald W.; MOSCHIS, George; LAWTON, Joseph T. Consumer Education and the Preschool Child. Journal of Consumer Affairs. Vol. 12, 1978, 12-29.

STEPHENS, Lowndes F.; MOORE, Roy L. Price Accuracy as a Consumer Skill. Journal of Advertising Research. Vol. 15 (4), August 1975, p. 27-34.

TELLES, Renato. Posicionamento e Reposicionamento de Marca: Uma Perspectiva Estratégica e Operacional dos Desafios e Riscos. Tese de Doutorado apresentada na FEA-USP, 2004, p.1-239.

TERRA. Especial dia das crianças 2004. Disponível em: $<$ http://www.terra.com.br/criancas/diadascriancas2004/comosurgiu.htm>. Acessado em: $11 \mathrm{de}$ novembro de 2007.

TOLEDO, Geraldo L.; HEMZO, Miguel A. O Processo de Posicionamento e o Marketing Estratégico. Anais do XV ENANPAD, Belo Horizonte, 1991, p.1-17. 
TOLLEY, B. Stuart. Identifying User Through a Segmentation Study. Journal of Marketing. April 1975, p.69-71.

TYNAN, Caroline A.; DRAYTON, Jennifer. Market Segmentation. Journal of Marketing Management. Vol. 2(3), 1987, p.301-335.

USA TODAY. Heinz unveils new blue ketchup. Edição 04/07/2003. Disponível em: http://www.usatoday.com/money/industries/food/2003-04-07-blue-ketchup_x.htm. Acessado em: 13/07/2007.

WhetTEN, D. A.; GODFREY, P. C. Identity in Organization: Building Theory Through Conversations. Thousand Oaks, CA: Sage Publications, 1998.

VECCHIO, G. D. Creating Ever-Cool - A Guide to a Kids Heart. Pelican, Lousiana, 2002.

VELOSO, Andres R.; HILDEBRAND, Diogo F. N. A criança no ambiente varejista: estudo exploratório na Base da Pirâmide. II Encontro de Marketing da Anpad, Rio de Janeiro, 2006.

VELOSO, Andres R.; HILDEBRAND, Diogo F. N. Representação Social Do Ato De Comprar Para O Consumidor Infantil de Alta Renda. Anais do XXI Encontro Nacional de Programas de Pós-Graduação da Anpad, Rio de Janeiro, 2007.

VELOSO, Andres R.; HILDEBRAND, Diogo F. N. DARÉ, Patrícia R. C. Uma visão holística da criança no varejo de baixa renda. III Encontro de Marketing da Anpad, Curitiba, 2008.

VOSS, Chris; TSIKRIKTSIS, Nikos; FROHLICH, Mark. Case research in operations management. International Journal of Operations \& Production Management. Vol. 22(2), 2002, p.195-219.

WALDORF. Escola Waldorf de São Paulo. Disponível em: www.waldorf.com.br. Acessado em: $12 / 06 / 2008$.

WARD, Scott. Consumer Socialization. Journal of Consumer Research, Vol. 1, 1974, p.1-14.

WARD, Scott. Contributions of Socialization Theory to Consumer Behavior. American Behavioral Scientist. Vol. 21 (4), Mar. Apr. 1978, p. 501-514.

WARD, Scott; WACKMAN, Daniel. Consumer Socialization: Initial Study Results. Advances in Consumer Research, Vol. 1 (1), 1974, p. 120-125. 
WEINSTEIN, Art. Segmentação de Mercado: Com Apêndice - Segmentação de Mercado no Brasil. Ed. Atlas, São Paulo, 1995, p.1-314.

WIND, Yoram. Issues and Advances in Segmentation Research. Journal of Marketing Research. Vol. XV, August 1978, p.317-337.

WIND, Yoram; DOUGLAS, Susan P. International Market Segmentation. European Journal of Marketing. Vol. 6(1), 1972, p.17-25.

WOODSIDE, Arch G.; WILSON, Elizabeth J. Case Study Research Methods for Theory Building. The Journal of Business \& Industrial Marketing. Vol. 18 (6/7), 2002, p. 493-508.

WYNER, Gordon; OWEN, Hilary. What's Your Position? Marketing Research. Vol. 6(1), Winter 1994, p.54-56.

YIN, R. K., Estudo de caso: Planejamento e métodos. Porto Alegre, Ed. Bookman, 2.ed., 2001, p.1-205. 


\section{APÊNDICE 1 - O CONCEITO DE SEGMENTAÇÃO}

\begin{tabular}{|c|c|}
\hline Autor & Definição \\
\hline $\begin{array}{l}\text { Smith }(1956, \\
\text { p.5) }\end{array}$ & $\begin{array}{l}\text { "Segmentação está baseada no desenvolvimento do lado da demanda de mercado e representa um ajuste mais racional e preciso entre os } \\
\text { produtos/esforços de marketing e os requerimentos do consumidor ou usuário." }\end{array}$ \\
\hline $\begin{array}{l}\text { Brandt }(1966, \\
\text { p. 25) }\end{array}$ & $\begin{array}{l}\text { "Segmentar o mercado é o processo de agrupar indivíduos que se espera que tenham reações similares (elasticidade promocional), durante } \\
\text { determinado período de tempo, aos esforços de marketing da empresa." }\end{array}$ \\
\hline $\begin{array}{l}\text { Andreasen } \\
(1966, \text { p. } 341)\end{array}$ & $\begin{array}{l}\text { "Essencialmente, o conceito é que ao separar os compradores em grupos tendo diferentes níveis de conhecimento, atitudes e comportamentos em } \\
\text { relação a determinado produto ou serviço, então diferenciando as estratégias de marketing entre esses grupos tanto em qualidade como em } \\
\text { qualidade, os profissionais de marketing poderiam aumentar os lucros da empresa, em relação os lucros que teriam caso tratassem o mercado } \\
\text { como um mercado de massa." }\end{array}$ \\
\hline $\begin{array}{l}\text { Barnett }(1969, \\
\text { p.152) }\end{array}$ & $\begin{array}{l}\text { "A segmentação refere-se a noção de que o grupo de consumidores que constitui um mercado para determinado produto ou serviço pode ser } \\
\text { dividido em grupos menores, cada um com diferentes necessidades e desejos." }\end{array}$ \\
\hline $\begin{array}{l}\text { fqClaycamp e } \\
\text { Massy }(1968, \text { p. } \\
\text { 388; p. 392) }\end{array}$ & $\begin{array}{l}\text { "A estratégia de segmentação geralmente parece estar quase que equacionada com o ato de definir subpartes de um mercado total." } \\
\text { "[...] parece claro que segmentação deve ser considerada como um processo de agregação ao invés de desagregação." }\end{array}$ \\
\hline $\begin{array}{l}\text { Johnson (1971, } \\
\text { p. 13) }\end{array}$ & $\begin{array}{l}\text { "Apesar de o termo evocar a idéia de cortar o mercado em pequenos pedaços, o real papel de tal pesquisa é mais básico e potencialmente mais } \\
\text { valioso. Nesta discussão, análise da segmentação de mercado refere-se ao exame da estrutura do mercado como ela é percebida pelos } \\
\text { consumidores, preferencialmente utilizando um modelo geométrico espacial, e na previsão da intensidade da demanda para um potencial produto } \\
\text { posicionado em qualquer lugar no espaço." }\end{array}$ \\
\hline $\begin{array}{l}\text { Wind e Douglas } \\
(1972, \text { p. } 17)\end{array}$ & $\begin{array}{l}\text { "Dada a heterogeneidade da maioria dos mercados, segmentação tanto em mercados nacionais como em mercados internacionais envolve a } \\
\text { quebra dos mercados para um determinado produto ou serviço em particular, em segmentos de consumidores que diferem em termos das suas } \\
\text { respostas às estratégias de marketing." }\end{array}$ \\
\hline $\begin{array}{l}\text { Assael e } \\
\text { Roscoe }(1976, \\
\text { p. } 67)\end{array}$ & $\begin{array}{l}\text { "Segmentação de mercado tem sido aceita como uma ferramenta estratégica de marketing para definir mercados e consequentemente alocar } \\
\text { recursos." }\end{array}$ \\
\hline $\begin{array}{l}\text { Beane e Ennis } \\
(1987, \text { p. } 20)\end{array}$ & $\begin{array}{l}\text { "A premissa inicial ao segmentar um mercado é de que segmentos realmente existem. Em outras palavras, a suposição de que o mercado não é } \\
\text { totalmente homogêneo. Segmentação de mercado é feita por duas razões principais: } \\
\text { 1) Para buscar novas oportunidades de produtos ou áreas que poderiam ser receptivas para o reposicionamento de produtos atuais } \\
\text { 2) Para criar mensagens de propaganda melhoradas por meio do ganho de um melhor entendimento dos seus consumidores." }\end{array}$ \\
\hline $\begin{array}{l}\text { Tynan e } \\
\text { Drayton }(1987, \\
\text { p. } 301)\end{array}$ & $\begin{array}{l}\text { "Segmentação de mercado é crucial para a estratégia de marketing. Seu objetivo é identificar e delinear segmentos de mercado ou "grupo de } \\
\text { consumidores" que a partir daí se tornarão alvos dos planos de marketing da companhia. A vantagem para a administração de marketing reside no } \\
\text { fato de que esta técnica divide o mercado total em segmentos relativamente homogêneos que são identificados por algumas características em } \\
\text { comum". }\end{array}$ \\
\hline $\begin{array}{l}\text { Toledo e } \\
\text { Hemzo (1991, } \\
\text { p. 4) }\end{array}$ & $\begin{array}{l}\text { "O processo de segmentação de mercado parte do reconhecimento, pela empresa, de que normalmente não lhe será viável atender a todos os } \\
\text { consumidores de um determinado mercado. As variáveis incontroláveis do ambiente, tanto as relacionadas com o perfil e o comportamento do } \\
\text { consumidor como aquelas decorrentes de melhor posição competitiva dos concorrentes, podem conduzir a empresa à identificação de segmentos } \\
\text { mais atrativos e mais compatíveis com seus recursos". }\end{array}$ \\
\hline Richers (1991a) & $\begin{array}{l}\text { "Segmentação é uma técnica ou estratégia que a empresa utiliza para focar seus esforços em determinado segmento do mercado que apresente } \\
\text { características e vontades similares". }\end{array}$ \\
\hline
\end{tabular}




\begin{tabular}{|c|c|}
\hline $\begin{array}{l}\text { Danneels } \\
(1995, \text { p.36) }\end{array}$ & $\begin{array}{l}\text { "Segmentação de mercado é definida como o processo de divisão do mercado total num número de menores e mais homogêneos sub-mercados, } \\
\text { denominados segmentos de mercado." }\end{array}$ \\
\hline $\begin{array}{l}\text { Weinstein } \\
(1995, \text { p.18) }\end{array}$ & $\begin{array}{l}\text { "O processo de dividir mercados em grupos de consumidores potenciais com necessidades e/ou características similares, que, provavelmente } \\
\text { exibirão comportamento de compra similar." }\end{array}$ \\
\hline $\begin{array}{l}\text { Hooley e } \\
\text { Saunders (1996, } \\
\text { p.192-193) }\end{array}$ & $\begin{array}{l}\text { "Existem três premissas básicas na segmentação como abordagem para o marketing: (1) Os clientes diferem um dos outros em alguns aspectos } \\
\text { que poderiam ser usados para dividir o mercado total; (2) Os segmentos podem ser identificados através de características mensuráveis que } \\
\text { possibilitam a estimativa do seu valor potencial como alvo de mercado; (3) Os segmentos selecionados podem ser isolados do restante do } \\
\text { mercado, possibilitando que eles sejam visados como uma oferta de mercado distinta." }\end{array}$ \\
\hline $\begin{array}{l}\text { McDonald e } \\
\text { Dunbar }(1998, \\
\text { p. 15) }\end{array}$ & $\begin{array}{l}\text { "Segmentação de mercado é o processo de dividir consumidores, ou potenciais consumidores, de um determinado mercado em diferentes grupos, } \\
\text { ou segmentos, nos quais os consumidores têm os mesmos ou similares requerimentos satisfeitos por um distinto mix de marketing." }\end{array}$ \\
\hline $\begin{array}{l}\text { Lambim }(2000, \\
\text { p.235) }\end{array}$ & $\begin{array}{l}\text { "[...] repartição inicial do mercado total em subconjuntos, denominados segmentos de mercado, homogêneos do ponto de vista das necessidades, } \\
\text { dos comportamentos, das motivações de compra, e suscetíveis de constituírem mercados potenciais distintos." }\end{array}$ \\
\hline $\begin{array}{l}\text { Schiffman e } \\
\text { Kanuk }(2000 \text {, } \\
\text {,p31) }\end{array}$ & $\begin{array}{l}\text { "A segmentação de mercado pode ser definida como o processo de divisão de um mercado em subconjuntos distintos de consumidores com } \\
\text { necessidades ou características comuns e de seleção de um ou mais segmentos aos quais se dirigir com um mix ou composto de marketing } \\
\text { distinto." }\end{array}$ \\
\hline $\begin{array}{l}\text { Hooley et al. } \\
(2001)\end{array}$ & $\begin{array}{l}\text { "Método que possibilita que profissionais de marketing dividam o mercado em grupo de clientes similares, sendo que esses grupos apresentam } \\
\text { diferenças significativas entre si." }\end{array}$ \\
\hline $\begin{array}{l}\text { Bradley }(2003, \\
\text { p. 47) }\end{array}$ & $\begin{array}{l}\text { "Segmentação de mercado refere-se a atividade de identificar e definir o perfil de distintos grupos de compradores que podem requerer produtos } \\
\text { separados, comunicados e entregues de forma diferente." }\end{array}$ \\
\hline $\begin{array}{l}\text { Churchill e } \\
\text { Peter }(2005 . \\
\text { p.204-205) }\end{array}$ & $\begin{array}{l}\text { "Segmentação de mercado é o processo de dividir um mercado em grupos de compradores potenciais que tenham semelhantes necessidades e } \\
\text { desejos, percepções de valores ou comportamentos de compra." }\end{array}$ \\
\hline $\begin{array}{l}\text { Kotler e } \\
\text { Armstrong } \\
(2005, \text { p.172) }\end{array}$ & $\begin{array}{l}\text { "[...] segmentação de mercado - divisão de um mercado em grupos menores de compradores com necessidades, características ou } \\
\text { comportamentos diferentes que poderiam requerer produtos ou mixes de marketing distintos." }\end{array}$ \\
\hline $\begin{array}{l}\text { Ferrell e } \\
\text { Hartline }(2005, \\
\text { p.153) }\end{array}$ & $\begin{array}{l}\text { "Da perspectiva de estratégia de marketing, definimos segmentação de mercado como o processo de divisão do mercado total, para um } \\
\text { determinado produto ou uma categoria de produtos, em segmentos ou grupos relativamente homogêneos. Para ser verdadeiramente eficaz, a } \\
\text { segmentação deve criar grupos cujos membros tenham gostos, necessidades, desejos ou preferências similares, mas que sejam, como grupos } \\
\text { propriamente, dessemelhantes entre si." }\end{array}$ \\
\hline $\begin{array}{l}\text { Kotler e Keller } \\
(2006)\end{array}$ & $\begin{array}{l}\text { "Um segmento de mercado consiste em um grande grupo de consumidores que possuem as mesmas preferências. Os profissionais de marketing } \\
\text { não criam os segmentos; sua tarefa é identificá-los e decidir em quais vão se concentrar." }\end{array}$ \\
\hline $\begin{array}{l}\text { American } \\
\text { Marketing } \\
\text { Association } \\
(2008)\end{array}$ & $\begin{array}{l}\text { "Processo de subdividir o Mercado em distintos subgrupos de consumidores que se comportam de forma similar ou que tem necessidades } \\
\text { similares. Cada subsegmento pode ser escolhido como um mercado alvo para ser atingido por uma distinta estratégia de marketing. O processo } \\
\text { começa com uma base de segmentação - um fator produto especifico que reflete as diferenças nos requerimentos dos consumidores ou } \\
\text { responsividade às variáveis de marketing (possibilidades são comportamento de compra, uso, benefícios buscados, intenções, preferências ou } \\
\text { lealdade). A partir daí descritores do segmento são escolhidos, baseados na sua habilidade em identificar segmentos, em dar conta da variância na } \\
\text { base de segmentação, e para sugerir implicações competitivas estratégicas (exemplos de descritores são demográficos, geográficos, psicográficos, } \\
\text { tamanho do consumidor, e indústria). Para ter um valor estratégico, os segmentos resultantes devem ser mensuráveis, accessíveis, suficientemente } \\
\text { diferentes para justificar uma variância significativa na estratégia da empresa, substanciais, e duráveis." }\end{array}$ \\
\hline
\end{tabular}


APÊNDICE 2 - O CONCEITO DE POSICIONAMENTO

\begin{tabular}{|c|c|}
\hline Autores & Conceito de Posicionamento \\
\hline $\begin{array}{l}\text { Alpert e Gaty } \\
(1969, \text { p.65) }\end{array}$ & $\begin{array}{l}\text { "A diferenciação das marcas por meio do estudo das formas como seus consumidores diferem, assim como as percepções dos consumidores } \\
\text { sobre como as marcas se diferenciam é denominado "posicionamento de produto"." }\end{array}$ \\
\hline $\begin{array}{l}\text { Ries e Trout (1972, } \\
\text { p.2) }\end{array}$ & $\begin{array}{l}\text { "Antigamente, posicionamento era usado num restrito sentido para indicar aquilo que o profissional da propaganda fazia para o produto. Hoje } \\
\text { em dia, posicionamento é usado num sentido mais amplo para significar aquilo que o profissional da propaganda faz para o produto na mente } \\
\text { do potencial cliente". }\end{array}$ \\
\hline $\begin{array}{l}\text { Achenbaun }(1974, \\
\text { p.22) }\end{array}$ & $\begin{array}{l}\text { "Primeiro, existe o elemento da decisão. Para começar, uma estratégia deve indicar que você está tomando a iniciativa, que você decidiu por } \\
\text { um curso de ação sobre o futuro. [...] Segundo, existe o elemento da limitação. Tomar uma posição significa reconhecer que você não pode } \\
\text { ser tudo, que você deve priorizar uma certa direção especifica. [...] Em terceiro, existe o tema; ou seja, os assuntos que você irá abordar." }\end{array}$ \\
\hline $\begin{array}{l}\text { Houston e Hanieski } \\
(1976, \text { p. } 38)\end{array}$ & $\begin{array}{l}\text { "Posicionamento pode ser facilmente descrito como a estratégia promocional que tenta colocar uma marca em relação a uma ou mais } \\
\text { dimensões relativas a outras marcas na mesma classe genérica." }\end{array}$ \\
\hline $\begin{array}{l}\text { Doyle e Saunders } \\
(1985, \text { p.26) }\end{array}$ & $\begin{array}{l}\text { "Após a escolha dos segmentos alvo, os administradores devem decidir como competir em cada um destes segmentos. Administradores } \\
\text { orientados para produto geralmente subestimam a necessidade de desenvolver vantagens competitivas se eles querem ganhar mercados } \\
\text { lucrativamente. Idealmente, o posicionamento deve ser sustentável e não facilmente copiável pelos competidores." }\end{array}$ \\
\hline $\begin{array}{l}\text { Shostack }(1987, \\
\text { p.34) }\end{array}$ & $\begin{array}{l}\text { "Quando uma firma ou provedor estabelece e mantêm um distintivo lugar para si mesmo e sua oferta no mercado, diz-se que está posicionado } \\
\text { com sucesso." }\end{array}$ \\
\hline $\begin{array}{l}\text { Aaker e Shansby } \\
(1988, \text { p.56) }\end{array}$ & $\begin{array}{l}\text { "Posicionamento significa diferentes coisas para diferentes pessoas. Para alguns, significa uma decisão de segmentação. Para outros é uma } \\
\text { questão de imagem. Para mais outros significa a seleção das características do produto que serão enfatizadas. Poucos administradores } \\
\text { consideram todas essas alternativas. [...] O termo posicionamento difere do antigo conceito de imagem em função de implicar num quadro de } \\
\text { referência, sendo o ponto de referência a concorrência." }\end{array}$ \\
\hline $\begin{array}{l}\text { Hendom e } \\
\text { Williams }(1988, \\
\text { p.70) }\end{array}$ & $\begin{array}{l}\text { "Posicionamento é a estratégia de marketing que é direcionada para um segmento de mercado em particular e desenhada para conquistar uma } \\
\text { posição desejada na mente dos consumidores." }\end{array}$ \\
\hline $\begin{array}{l}\text { DiMingo }(1989, \\
\text { p.35) }\end{array}$ & $\begin{array}{l}\text { "O primeiro lado da moeda do posicionamento - posicionamento de mercado - é o processo de identificar e selecionar o mercado ou } \\
\text { segmento que representa negócios potenciais, alvejando competidores vulneráveis, e criando uma estratégia competitiva. [...] Posicionamento } \\
\text { psicológico, o segundo lado da moeda do posicionamento, envolve a criação de uma distinta imagem corporativa ou de produto intimamente } \\
\text { baseada em fatores de posicionamento de mercado, para então utilizar as ferramentas de comunicação (propaganda, relações públicas, ponto } \\
\text { de venda, entre outros materiais de apoio) para mover o potencial cliente para uma decisão de compra." }\end{array}$ \\
\hline $\begin{array}{l}\text { Toledo e Hemzo } \\
(1991, \text { p.4-5) }\end{array}$ & $\begin{array}{l}\text { "O processo de posicionamento é uma seqüência natural do processo estratégico de segmentação de mercado. A análise voltada para a } \\
\text { segmentação permite verificar como o mercado é definido e direcionar os esforços de marketing para uma ou mais oportunidades de mercado. } \\
\text { O posicionamento direciona-se a um segmento de mercado-alvo e possibilita avaliar como competir mais efetivamente naquele segmento. } \\
\text { [...]O processo de posicionamento de mercado tem como pressuposto a determinação de critérios para o sucesso competitivo - conhecimento } \\
\text { do que o mercado quer e necessita, identificação das forças e fraquezas da empresa e de seus concorrentes e estabelecimento de condições } \\
\text { para atingir as exigências do mercado melhor que os concorrentes." }\end{array}$ \\
\hline $\begin{array}{l}\text { Lautman }(1993, p . \\
12-13)\end{array}$ & $\begin{array}{l}\text { "O posicionamento pode ser dividido em três componentes que tipicamente o caracterizam. [...] O primeiro passo ao abordar o problema de } \\
\text { posicionamento ou reposicionamento é identificar os atributos intrínsecos do produto ou serviço. [...] apesar dos atributos e dos atos de } \\
\text { serviço terem um valor intrínseco para o consumidor, eles não serão assim reconhecidos caso não tenham um beneficio percebido associado. } \\
{[\ldots . .] \text { Benefícios derivam dos atributos e podem assumir três formas principais: funcionais, físicos ou psicológicos. [...] A comunicação de }}\end{array}$ \\
\hline
\end{tabular}




\begin{tabular}{|c|c|}
\hline & ributos e benefícios pode ser atingida por declarações especificas. \\
\hline $\begin{array}{l}\text { Ansari et al. }(1994, \\
\text { p.248) }\end{array}$ & $\begin{array}{l}\text { "Posicionamento, o lugar que um produto ocupa em determinado mercado, é a fundação da estratégia de marketing. O posicionamento de } \\
\text { uma marca a diferencia dos seus competidores com base em atributos considerados importantes pelos consumidores-alvo e lhe dá uma } \\
\text { imagem distinta em suas mentes.[...] As firmas posicionam suas marcas selecionando o mix ótimo de atributos de produto tangíveis e } \\
\text { intangíveis, assim como seus preços." }\end{array}$ \\
\hline $\begin{array}{l}\text { Wyner e Owen } \\
(1994, \text { p. } 54-56)\end{array}$ & $\begin{array}{l}\text { "O imaginário da localização reflete a prática de descrever o status da marca com seus consumidores como uma posição na sua mente. Essa } \\
\text { posição pode ser pensada como um local num mapa que é descrito pelas dimensões que o consumidor usa quando pensa sobre uma categoria. } \\
\text { Essas dimensões podem ser definidas por imagens, atributos de produto, ou ambos." }\end{array}$ \\
\hline $\begin{array}{l}\text { Hooley e Saunders } \\
(1996, \text { p.51) }\end{array}$ & $\begin{array}{l}\text { "O posicionamento competitivo da empresa é uma declaração dos mercados-alvo, isto é, onde a empresa irá competir e a vantagem } \\
\text { diferencial, ou seja, como a empresa irá competir". }\end{array}$ \\
\hline $\begin{array}{l}\text { Aaker }(1998, \\
\text { p.115) }\end{array}$ & $\begin{array}{l}\text { "O posicionamento é estreitamente relacionado ao conceito de imagem e associação exceto quando implica um quadro de referencia no qual } \\
\text { está a concorrência". }\end{array}$ \\
\hline $\begin{array}{l}\text { McDonald e } \\
\text { Dunbar }(1998, p \text {. } \\
\text { XXI) }\end{array}$ & "O processo de selecionar, delinear e casar o segmento de mercado com um produto que lhe seja o mais compatível". \\
\hline $\begin{array}{l}\text { Blankson e } \\
\text { Kalafatis (1999, } \\
\text { p.109-110) }\end{array}$ & $\begin{array}{l}\text { "[...] o processo de posicionamento pode ser descrito como interativo e requer um envolvimento deliberado e proativo do profissional de } \\
\text { marketing. [...] pode ser inferido que as estratégias efetivas de posicionamento, tanto para serviços como para produtos, podem ser obtidas se } \\
\text { as características especificas de diferenciação são apreciadas pelo profissional de marketing." }\end{array}$ \\
\hline $\begin{array}{l}\text { Richers (2000, } \\
\text { p.102-103) }\end{array}$ & $\begin{array}{l}\text { "Posicionamento é geralmente entendido como um "lugar" no mercado em que um produto é colocado com um mínimo de interferência de } \\
\text { outras marcas do mesmo gênero. O lugar em si é determinado pela maneira como o consumidor percebe e entende o produto". }\end{array}$ \\
\hline $\begin{array}{l}\text { Lambim }(2000 \text {, } \\
\text { p.272) }\end{array}$ & "O posicionamento define a forma como a marca ou a empresa pretende ser percebida pelos compradores-alvo". \\
\hline $\begin{array}{l}\text { Ferrell e Hartline } \\
(2005, \text { p.171-172) }\end{array}$ & $\begin{array}{l}\text { "Posicionamento refere-se à criação de uma imagem mental da oferta de produtos e suas características diferenciadoras na mente dos } \\
\text { consumidores do mercado alvo. Essa imagem mental pode basear-se em diferenças reais ou percebidas entre às ofertas de produto. Enquanto a } \\
\text { diferenciação refere-se ao próprio produto, o posicionamento está relacionado às percepções que os consumidores têm dos benefícios do } \\
\text { produto, reais ou imaginários." }\end{array}$ \\
\hline Craft & $\begin{array}{l}\text { "[...] posicionamento é descrito como uma estratégia para identificar e direcionar os recursos de marketing para segmentos de mercado } \\
\text { desejados". }\end{array}$ \\
\hline $\begin{array}{l}\text { Oliveira e } \\
\text { Campomar }(2006, \\
\text { p. 13) }\end{array}$ & $\begin{array}{l}\text { "Posicionamento é a definição de uma proposta de valor que interesse à empresa, que seja significativa a um público-alvo e que, na percepção } \\
\text { dele, seja distintiva e mais atrativa em relação às propostas elaboradas pela concorrência." }\end{array}$ \\
\hline $\begin{array}{l}\text { Hartmann et al. } \\
(2006, \text { p.10) }\end{array}$ & $\begin{array}{l}\text { "[...] posicionamento de marca está baseado nas interações de todas as ferramentas de marketing, com um acentuado destaque para as } \\
\text { comunicações de marketing por causa da sua relevância no processo de moldar distintas percepções do consumidor." }\end{array}$ \\
\hline $\begin{array}{l}\text { Srivastava (2006, } \\
\text { p.67) }\end{array}$ & $\begin{array}{l}\text { "Posicionamento é uma técnica que ajuda e facilita a lembrança de marca em função da sua abordagem de ocupar um lugar na mente do } \\
\text { consumidor". }\end{array}$ \\
\hline $\begin{array}{l}\text { Keller e Machado } \\
(2006, \text { p. } 70)\end{array}$ & $\begin{array}{l}\text { "Posicionamento, como o nome dá a entender, implica descobrir a 'localização' adequada na mente de um grupo de consumidores ou } \\
\text { segmento de mercado, de modo que eles pensem em um produto ou serviço do modo desejado". }\end{array}$ \\
\hline $\begin{array}{l}\text { Kerin et al. }(2008, \\
\text { p. } 241)\end{array}$ & $\begin{array}{l}\text { "O posicionamento de produto se refere ao lugar que uma oferta ocupa nas mentes dos consumidores sobre importantes atributos em relação } \\
\text { aos produtos da concorrência" }\end{array}$ \\
\hline
\end{tabular}




\section{APÊNDICE 3 - MODELO DA CARTA DE APRESENTAÇÃO}

\section{Caro Sr.}

Venho por meio desta confirmar o contato realizado pela Srta Beatriz e apresentar os objetivos desta pesquisa. No momento estou em fase final de conclusão do meu curso de Doutorado em Administração (Ênfase em Marketing) na Universidade de São Paulo, contando com a orientação do Prof. Titular Marcos Cortez Campomar. Tenho como foco de estudo o consumo infantil, tema ainda pouco estudado no Brasil. Pretendo entrevistar algumas empresas brasileiras para compreender melhor o processo de segmentação e posicionamento das empresas focadas em brinquedos.

Para a conclusão da minha pesquisa de Doutorado, necessito realizar entrevistas com gerentes ou analistas de marketing para melhor compreender as questões relacionadas ao público infantil. Portanto, conto com a colaboração de vossa empresa para a continuidade deste trabalho.

Em anexo estou enviando o meu Currículo Lattes, no qual constam todas as pesquisas que já realizei. Esse currículo também pode ser acessado pelo site http://lattes.cnpq.br/ ou diretamente pelo link:

http://buscatextual.cnpq.br/buscatextual/visualizacv.jsp?id=K4777806P5

Atualmente estou lecionando disciplinas de marketing na Universidade Presbiteriana Mackenzie, o que pode ser confirmado nos links abaixo:

http://www4.mackenzie.com.br/149.html (corpo docente do curso de Especialização em Marketing)

http://www4.mackenzie.br/4434.html (corpo docente do Centro de Ciências Sociais e Aplicadas)

Também sou professor na Fundação Escola de Comércio Álvares Penteado - FECAP, o que pode ser verificado no link abaixo:

http://www.fecap.br/PortalNovo/interna_corpodocente2.asp

Estou a disposição para outras dúvidas que se fizerem presente.

Agradeço desde já a colaboração.

Muito Obrigado,

Prof. Andres Rodriguez Veloso

Professor da Universidade Presbiteriana Mackenzie

Aluno do Programa de Doutorado da Universidade de São Paulo 


\section{APÊNDICE 4 - ROTEIRO DE ENTREVISTA}

\section{Segmentação}

1.1. Qual o público alvo atendido pela empresa?

1.2. Como se dá o processo de análise e seleção do público alvo?

1.3. A empresa realiza pesquisas para identificação das características do mercado e seleção do público alvo?

1.4. Quais são as variáveis utilizadas para identificar os segmentos atrativos para a empresa (idade, sexo, renda, região geográfica, etc)?

1.5. Quais são as técnicas de pesquisa utilizadas para coletar os dados da pesquisa de segmentação?

1.6. Quais são as ferramentas de análise (técnicas estatísticas) dos dados coletados durante a pesquisa de segmentação?

1.7. Como a empresa identifica a faixa etária para qual os brinquedos são destinados?

\section{Posicionamento}

2.1. Qual o posicionamento pretendido pela empresa?

2.2. Como acontece o processo de desenvolvimento de novos produtos?

2.3. Quais as dificuldades encontradas no processo de aprovação dos brinquedos junto ao Inmetro?

2.4. São realizados testes de mercado com crianças para identificar a possibilidade de sucesso do lançamento do produto?

2.5. Quais as ferramentas de comunicação utilizadas para comunicar o posicionamento pretendido junto ao mercado infantil?

2.6. Qual o papel da marca e de personagens (licenciamento, co-branding) no lançamento de produtos?

2.7. Qual o papel do preço junto ao processo de posicionamento?

2.8. Quais são as estratégias de distribuição adotadas para atender ao consumidor infantil?

2.9. São realizadas pesquisas para identificar se o posicionamento pretendido está sendo efetivamente alcançado 